\title{
Palliatieve zorg door \\ verpleegkundigen
}

Redactie

Adriaan Ph. Visser

Johan J.R. Bilsen

Anneke L. Francke 
NNY73

Palliatieve zorg door verpleegkundigen

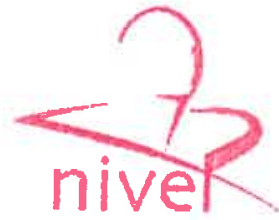

bibllotheok

otterstraat 118-124

postbus 1568

3500 bn utrecht

tel $0302729614 / 615$

fax 0302729729

blbliotheok@nlvel.nl muw.nivel.nl 
De serie hbo verpleegkunde bevat de volgende delen:

- Communicatieve vaardigheden voor verpleegkundigen*

- Dementie en psychiatrie*

m Gezondheidsbevordering en preventie voor verpleegkundigen en verpleegkundig specialisten

- Patiëntenvoorlichting door verpleegkundigen

- Verpleegkundige diagnoses in de psychiatrie

- Verpleegkundige interventies

- Verpleegkundige zorgresultaten*

$*$ in voorbereiding 


\section{Palliatieve zorg door verpleegkundigen}

redactie

Adriaan Ph. Visser

Johan J.R. Bilsen

Anneke L. Francke 
(C) Reed Business, Amsterdam 2011

Omslagontwerp: Mariël Lam bno, 's-Hertogenbosch Basisontwerp binnenwerk: Martin Majoor, Arnhem

Reed Business bv, Postbus 152, 1000 AD Amsterdam.

Aan de totstandkoming van deze uitgave is de uiterste zorg besteed. Voor informatie die nochtans onvolledig of onjuist is opgenomen, aanvaarden auteur(s), redactie en uitgever geen aansprakelijkheid. Voor eventuele verbeteringen van de opgenomen gegevens houden zij zich gaarne aanbevolen.

Waar dit mogelijk was, is aan auteursrechtelijke verplichtingen voldaan. Wij verzoeken eenieder die meent aanspraken te kunnen ontlenen aan in dit boek opgenomen teksten en afbeeldingen, zich in verbinding te stellen met de uitgever.

Behoudens de in of krachtens de Auteurswet van 1912 gestelde uitzonderingen mag niets uit deze uitgave worden verveelvoudigd, opgeslagen in een geautomatiseerd gegevensbestand, of openbaar gemaakt, in enige vorm of op enige wijze, hetzij elektronisch, mechanisch, door fotokopieẻn, opnamen of op enige andere manier, zonder voorafgaande schriftelijke toestemming van de uitgever. Voor zover het maken van reprografische verveelvoudigingen uit deze uitgave is toegestaan op grond van artikel 16 h Auteurswet 1912, dient men de daarvoor wettelijk verschuldigde vergoedingen te voldoen aan de Stichting Reprorecht (Postbus 3051, 2130 KB Hoofddorp, www.reprorecht.nl). Voor het overnemen van (een) gedeelte(n) uit deze uitgave in bloemlezingen, readers en andere compilatiewerken (artikel 16 Auteurswet 1912) kan men zich wenden tot de Stichting PRO (Stichting Publicatie- en Reproductierechten Organisatie, Postbus 3060, 2130 KB Hoofddorp, www.stichting-pro.nl). Voor het overnemen van (een) gedeelte(n) van deze uitgave ten behoeve van commerciële doeleinden dient men zich te wenden tot de uitgever.

ISBN 9789035233065

NUR 897 


\section{Voorwoord}

Palliatieve zorg is niet meer uit het landschap van de gezondheidszorg weg te denken. Sinds Cicely Saunders in 1967 met St. Christopher's in Londen het eerste hospice gestalte gaf, heeft de palliatieve zorg zich gestadig uitgebreid. Eerst beschikbaar als iets bijzonders, iets buitengewoons, is het nu een onderdeel van reguliere zorg geworden. Palliatieve zorg is ook niet langer aan kankerpatiënten voorbehouden. Palliatieve zorg wordt in hospices, afdelingen voor palliatieve zorg, bijna-thuis-huizen en thuis gegeven, maar ook in ziekenhuizen, verpleeg- en verzorgingshuizen, in psychiatrische instellingen of instellingen voor mensen met een handicap. Wie geen beroep op palliatieve zorg kan doen, krijgt niet waar hij recht op heeft. Kennis over palliatieve zorg en hoe die gegeven wordt, is daarom voor (bijna) alle verpleegkundigen en verzorgenden van belang.

\section{Verdieping}

Behalve uitgebreid heeft de palliatieve zorg zich ook verdiept. Het uitgangspunt is door de jaren heen bewaard gebleven: palliatieve zorg betreft de mens in zijn geheel, hij/zij wordt niet gereduceerd tot wat vanuit medisch perspectief belangrijk is; palliatieve zorg heeft niet alleen oog voor het lijden van de patiënt, maar ook voor dat van zijn familieleden; palliatieve zorg accepteert de grenzen aan het genezen en gaat ervan uit dat ook dan nog heel veel voor de patiënt en zijn familie kan en moet worden gedaan. Palliatieve zorg is vooral zorg voor het leven op het ogenblik dat de dood niet meer achter de horizon verborgen is. Palliatieve zorg is multidisciplinaire zorg. De opdracht waar de palliatieve patiënt en zijn familieleden de zorgverleners voor stellen, is te zwaar, te breed en te omvattend om die aan een of twee disciplines toe te vertrouwen. Palliatieve zorg vereist een samenspel van hulpverleners die elkaars werk kennen en waarderen, maar die ook plaats maken voor anderen als dat nodig is. Palliatieve zorg is zorg waarin verpleegkundigen een sterke rol hebben, een eigen verantwoordelijkheid, gericht op kwaliteit van leven ook als de dood niet meer weg te denken is, om ook dan te helpen het leven boven de ziekte uit te tillen.

Beslissingen van verpleegkundigen en verzorgenden reiken veel verder dan wat men met de term (medische) beslissingen bij het levenseinde is gaan benoemen. 
Goede zorg vergt een intensieve afstemming op wat voor de patiënt en zijn familie op dat ogenblik aan de orde is, goede zorg onderzoekt wat dan door en voor hen gewenst is en wat men derhalve als verpleegkundige of verzorgende kan doen. Juist de beslissingen over kleine dingen in het leven kunnen de kwaliteit van leven uitmaken in een fase waarin de tijd alles verdicht.

\section{Verschillen}

Hoewel er een grote mate van eensgezindheid is over wat palliatieve zorg inhoudt, zijn er ook verschillen. Die verschillen hangen onder meer samen met de omstandigheden waarin de palliatieve zorg gegeven wordt, en met de geschiedenis. Zeker tussen Nederland en Vlaanderen zijn die verschillen er: de palliatieve zorg wordt er in andere instellingen en organisaties gegeven, heeft een andere geschiedenis, is vanuit verschillende motieven gepromoot en daardoor zijn er verschillen in accenten. Een Nederlands-Vlaamse vergelijking zoals in dit boek plaatsvindt, heeft daarom een grote meerwaarde.

\section{Kwaliteit van zorg}

Palliatieve zorg heeft een uitstekende reputatie wat kwaliteit betreft. Dat heeft zeker te maken met de selectie van de hulpverleners. In de palliatieve zorg werken vaak hulpverleners die heel uitdrukkelijk voor dat domein van de zorg gekozen hebben, niet zelden op zoek naar een gebied waarin ze meer kans krijgen om zorg te geven zoals ze die willen geven. In een van onze onderzoeken zei een palliatief verpleegkundige toen haar gevraagd werd of ze het niet moeilijk vond op een palliatieve eenheid te werken, waar ze telkens weer de dood van haar patiënten moest meemaken: 'Nee, hier werken is niet moeilijk. Hier heb je de mogelijkheden om te doen wat je moet doen. Op een oncologieafdeling vond ik het veel moeilijker. Daar heb je vaak niet de kans om te doen wat je wilt doen.' Wellicht ligt de grootste uitdaging voor palliatieve zorg nu op die afdelingen die zich niet uitsluitend op deze patiëntengroep richten, maar de palliatieve zorg moeten realiseren samen met de andere taken en opdrachten.

\section{Bedreigingen}

Palliatieve zorg gaat niet vanzelf goed. In Nederland was de overheid lange tijd tegen hospices als een nieuwe laag in de zorgvoorzieningen. In Vlaanderen zagen de pioniers van de palliatieve zorg met bange ogen de uitbreiding van de palliatieve zorg tegemoet. Terwijl ze het toejuichten dat meer patiënten de kans zouden krijgen palliatieve zorg te ontvangen, waren ze bang dat het elan dat voor de kwaliteit zorgde zou verdwijnen.

Palliatieve zorg wordt onder meer bedreigd door medicalisering. Die is al hier en daar te zien. Palliatieve zorg wordt dan gedefinieerd als symptoomcontrole, het 
zwaartepunt van de zorg wordt gelegd bij medische beslissingen, en de arts wordt de belangrijkste figuur. De zorg voor het leven boet dan zwaar in. Palliatieve zorg wordt ook bedreigd door een te grote nadruk op de goede dood. Zeker voor beginners in de palliatieve zorg is het een verleiding een goede dood als een te bereiken doel te zien, en zichzelf en daardoor soms ook de patiënt af te rekenen op het behalen van dat doel. Wie geen vorderingen maakt naar dat doel toe, wordt dan een lastige patiënt, die de hulpverleners frustreert. Palliatieve zorg wordt ook bedreigd als hulpverleners meer bezig zijn met hun professionaliteit, met het maken en volgen van richtlijnen en protocollen in plaats van met de behoeften van de patiënt, meer met het bereiken van hun doelen dan met het realiseren van wat de patiënt en zijn familieleden echt deugd zou doen. Palliatieve zorg wordt ook bedreigd als er een te grote nadruk gelegd wordt op de grote beslissingen rondom het levenseinde, op het afsluiten van het leven en het vervullen van laatste wensen ten koste van de afstemming van de alledaagse zorg op de wensen en behoeften van patiënten en hun familieleden.

\section{Het handboek}

Palliatieve zorg, hoe edel het doel ook is, gaat dus niet vanzelf goed. Daarom is het goed dat er een handboek gemaakt is dat de verpleegkundigen en verzorgenden kennis laat maken met palliatieve zorg. Het handboek kan dienst doen als oriëntatie, als inwijding in een belangrijk deelgebied van het beroep. Wie ervaring heeft met palliatieve zorg, kan de eigen denkbeelden, de eigen opvattingen en de eigen praktijk toetsen aan de opvattingen van experts van wie de meesten gepokt en gemazeld zijn in de praktijk van de palliatieve zorg of er als onderzoeker jarenlang bij betrokken zijn geweest. Dat kan dan aanleiding zijn tot verdere studie, tot discussie en - indien nodig - tot het herzien of herijken van de eigen mening of de praktijk.

De meeste verpleegkundigen en verzorgenden zullen op een of andere manier met palliatieve zorg te maken krijgen, soms daarin een actieve rol spelen, soms daarover adviseren of de behoefte eraan opmerken, soms een mening gevraagd worden over de aard of de wenselijkheid ervan. Voor hen allen zal dit handboek een waardevolle bron zijn.

\section{Mieke Grypdonck}

Verpleegkundige en emeritus hoogleraar verplegingswetenschap aan de Universiteit Utrecht en de Universiteit Gent. Ze behaalde de titel van doctor aan de universiteit van Manchester en deed diverse onderzoeken naar de palliatieve zorg in Vlaanderen en Nederland. 



\section{Inhoud}

\section{Inleiding 11}

1 Inleiding in de palliatieve zorg 13

$1.1 \quad$ Begripsbepaling van palliatieve zorg 14

1.2 De geschiedenis van de palliatieve zorg in Nederland 17

1.3 De geschiedenis van de palliatieve zorg in Vlaanderen 24

1.4 Beslissingen aan het levenseinde en de rol van verpleegkundigen 31

1.5 Leren in de palliatieve zorg 38

2 Organisatie en aanbod van de palliatieve zorg 43

2.1 Netwerken in de palliatieve zorg 44

2.2 Intramurale palliatieve zorg 50

2.3 Palliatieve zorg thuis 54

2.4 Dagcentra en dagbehandeling 61

2.5 Zelfstandige hospicevoorzieningen 65

3 De actoren in het veld van de palliatieve zorg $6 \mathrm{~g}$

3.1 De houding van verpleegkundigen in de palliatieve zorg 70

3.2 Competenties van verpleegkundigen in de palliatieve zorg 76

3.3 Samenwerking van verpleegkundigen en artsen $\quad 85$

3.4 De rol van pastores 92

3.5 De rol van psychosociale hulpverleners 97

3.6 De rol van familiezorgers en vrijwilligers 103

4 Specifieke aspecten van palliatieve zorg 109

4.1 Zorg bij pijn en vermoeidheid 110

4.2 Psychosociale zorg 117

4.3 Spirituele zorg 129

4.4 Zorg rond het sterven 135

4.5 Complementaire zorgtoepassingen in de palliatieve zorg 144

4.6 Richtlijnen voor palliatieve zorg 150 
5 Palliatieve zorg voor specifieke groepen 155

5.1 Palliatieve zorg voor mensen met dementie 156

5.2 Palliatieve zorg voor kinderen $\quad 162$

5.3 Palliatieve zorg voor mensen met een niet-westerse achtergrond 172

5.4 Palliatieve zorg voor mensen met een verstandelijke beperking $\quad 178$

5.5 Palliatieve zorg in de psychiatrie 185

Bijlage Websites over palliatieve zorg 191

Redactie en auteurs 195

Register 201 


\section{Inleiding}

De medische zorg was tot vijfentwintig jaar geleden voornamelijk gericht op het voorkomen, het diagnosticeren en de genezing van ziekten. Aandacht voor de zorg tijdens het levenseinde is een recente ontwikkeling in de geneeskunde. De verpleegkunde was vanaf haar ontstaan vaak al gericht op mensen die niet meer te genezen zijn. Daaruit kwam in het midden van de vorige eeuw de moderne en wetenschappelijke palliatieve zorg voort. Het belang van goede palliatieve zorg groeide sterk door de toenemende vergrijzing, de langere levensduur van mensen en het toenemend aantal chronisch zieken.

Palliatieve zorg is in essentie gericht op het bevorderen van de levenskwaliteit van mensen met een ongeneeslijke aandoening. Palliatieve zorg is niet hetzelfde als terminale zorg, maar wordt vaak al ingezet vanaf de diagnose van een ongeneeslijke aandoening, soms zelfs al enkele jaren voor het overlijden. Het merendeel van de verpleegkundigen krijgt vroeg of laat te maken met zorg voor mensen in de laatste levensfase. In hoofdstuk 1 worden de achtergronden, het ontstaan en de geschiedenis van de palliatieve zorg uiteengezet, en wordt kort ingegaan op verschillende moeilijke beslissingen aan het levenseinde.

Er is niet één type palliatieve zorg. De organisatie en het aanbod zijn zeer divers. In hoofdstuk 2 wordt ingegaan op de rol van netwerken, intramurale palliatieve zorg, palliatieve thuiszorg, dagcentra en zelfstandige hospicevoorzieningen.

Een belangrijk kenmerk van palliatieve zorg betreft het multidisciplinaire karakter, waarbij verpleegkundigen nauw samenwerken met verzorgenden, artsen, paramedici en vrijwilligers. Verpleegkundigen zijn daarbij vaak sleutelfiguren in de zorg. Samenwerking vereist dat men zich bewust is van de eigen identiteit, houding en competenties. Daarop wordt in hoofdstuk 3 ingegaan.

Mensen in de palliatieve fase van hun ziekte krijgen vaak te maken met pijn en andere symptomen. Naast het tijdig signaleren van symptomen en goede symptoomcontrole is palliatieve zorg omvattender en gaat het bijvoorbeeld ook over het goed informeren van de patiënt, een luisterend oor, emotionele ondersteuning, aandacht voor de naasten, goede algemene lichamelijke verzorging en praktische hulp om het leven tot aan het einde waardevol te maken. Verder hebben verpleegkundigen een 
rol bij advance care planning. Dit betekent dat zij rekening houden met wat patiënten en hun familie in de toekomst aan zorg nodig hebben, en dit tijdig bespreken. In hoofdstuk 4 wordt een overzicht gegeven van de zorg bij pijn en vermoeidheid, psychosociale en spirituele zorg, zorg bij sterven en de toepassing van complementaire zorgvormen.

Palliatieve zorg werd in het verleden vaak in verband gebracht met zorg voor ongeneeslijke volwassen kankerpatiënten. De doelgroepen zijn de laatste jaren echter duidelijk verbreed tot mensen met een moeilijker te voorspellen ziektetraject of met specifieke vereisten, bijvoorbeeld op het vlak van besluitvorming. Hierbij kan men onder meer denken aan mensen met dementie, aan kinderen en aan psychiatrische patiënten. Een andere evolutie binnen de Nederlandse en Vlaamse samenleving is de toenemende culturele diversiteit, met eigen waarden en opvattingen over levenseindezorg en sterven. Deze tendensen vereisen aangepaste zorg. In hoofdstuk 5 wordt daarop dieper ingegaan.

\section{Hand boek voor verpleegkundigen}

In dit handboek voor verpleegkundigen wordt een overzicht gepresenteerd van de palliatieve zorg door verpleegkundigen in Nederland en Vlaanderen. Naar schatting krijgt twee derde van de verpleegkundigen in meerdere of mindere mate te maken met palliatieve zorg. Soms spelen ze daarin een directe rol, soms zijn ze adviserend of merken de nood op, terwijl ook hun mening gevraagd kan worden over wenselijkheid en de aard van de palliatieve zorg. Dit boek is op de eerste plaats voor hen bedoeld. Maar het kan ook een goede bron van informatie zijn voor andere geinteresseerde verpleegkundigen, verzorgenden of andere hulpverleners.

dr. Adriaan Visser prof.dr. Johan Bilsen prof.dr. Anneke Francke 


\section{Inleiding in de palliatieve zorg}

1.1 Begripsbepaling van palliatieve zorg $\quad 14$

1.2 De geschiedenis van de palliatieve zorg in Nederland 17

1.3 De geschiedenis van de palliatieve zorg in Vlaanderen 24

1.4 Beslissingen aan het levenseinde en de rol van verpleegkundigen 31

1.5 Leren in de palliatieve zorg 38 


\subsection{BEGRIPSBEPALING VAN PALLIATIEVE ZORG}

\section{Anneke Francke}

Aandacht voor mensen die ongeneeslijk ziek zijn is van alle tijden. Toch zien we in de afgelopen vijftien jaar bij beleidsmakers, zorgverleners en media een groeiende aandacht voor palliatieve zorg. Belangrijke redenen hiervoor zijn de vergrijzing van de bevolking en de toename van chronische aandoeningen (zoals kanker) die, vaak na een lange ziekteperiode, uiteindelijk resulteren in overlijden. Mogelijk speelt ook mee dat er in de huidige gezondheidszorg meer aandacht is dan enkele decennia geleden, voor zorg die niet-curatief en invasief is, maar waar juist aandacht uitgaat naar zaken als medemenselijkheid en de 'mens die meer is dan zijn of haar ziekte'.

\subsubsection{Wat is palliatieve zorg?}

Palliatieve zorg kan heel algemeen omschreven worden als de zorg die gericht is op het verzachten van alle vormen van lijden in de laatste levensfase. De Wereldgezondheidsorganisatie (WHO) geeft een meer specifieke omschrijving van palliatieve zorg:

Een benadering die de kwaliteit van het leven verbetert van patiënten en hun naasten die te maken hebben met een levensbedreigende aandoening, door het voorkomen en verlichten van lijden, door middel van tijdige signalering en zorgvuldige beoordeling en behandeling van pijn en andere problemen van lichamelijke, psychosociale en spirituele aard.

Als aanvulling op die definitie geeft de WHO daarnaast nog de volgende toelichting. Bij palliatieve zorg:

w is niet de genezing van de patiënt het doel, maar een zo hoog mogelijke kwaliteit van het resterende leven, waardoor het verloop van de levensbedreigende aandoening mogelijk positief beïnvloed wordt;

III is het sterven een normaal, natuurlijk proces, dat niet vertraagd of versneld wordt;

= is er aandacht voor de lichamelijke, psychische en sociale noden van de patiënt;

w worden de psychologische en spirituele aspecten in de zorg geïntegreerd benaderd;

= is er emotionele ondersteuning voor de patiënt en zijn naasten om zo actief mogelijk te leven;

= is er emotionele ondersteuning voor de naasten om te leren omgaan met de ziekte van de patiënt en met eigen rouwgevoelens;

n wordt vanuit een team zorgverleners gewerkt, zodat aan alle noden van patiënten en naasten tegemoet kan worden gekomen, indien nodig ook na het overlijden van de patiënt. ${ }^{1}$ 
Deze definitie en omschrijving laten zien dat palliatieve zorg een zeer veelomvattende vorm van zorg is. Over palliatieve zorg wordt vaak gesproken alsof het uitsluitend om de verlichting van pijn of andere symptomen zou gaan. Hoewel symptoomcontrole beslist belangrijk is (zie ook paragraaf 4.1), gaat het in de palliatieve zorg om meer. In de palliatieve zorg gaat het ook zeker over de emotionele ondersteuning van patiënt en naaste familie. Verpleegkundigen kunnen door persoonlijke aandacht, door 'er voor de ander te zijn', ertoe bijdragen dat ook de allerlaatste levensfase een goede fase kan zijn, waar het niet alleen gaat over lijden en het naderende overlijden, maar zeker ook over het 'leven van het leven dat rest'. ${ }^{2}$ De persoonlijke aandacht voor de familie houdt niet op bij het overlijden, maar strekt zich uit tot nazorg.

\subsubsection{Het palliatieve zorgcontinuủm}

De begrippen terminale zorg en palliatieve zorg worden soms als synoniemen van elkaar gebruikt, wat niet terecht is. Terminale zorg richt zich specifiek op zorg in de allerlaatste fase (de stervensfase), terwijl palliatieve zorg meestal al in een veel eerder stadium van start gaat. De palliatieve fase is een zorgcontinuüm dat begint bij de diagnose van een levensbedreigende aandoening die naar verwachting tot de dood zal leiden.3.4 In het begin van dit continuüm wordt vaak al gestart met (aspecten van) palliatieve zorg, maar daarnaast wordt dan vaak ook nog levensverlengende zorg gegeven (figuur 1.1).

Aan het eind van het continuüm worden de zorgbehoeften veelal omvangrijker en complexer en komt het accent geheel te liggen bij palliatieve zorg, gekenmerkt door een nadruk op kwaliteit van leven. Levensverlenging is dan geen doel meer. Het palliatieve zorgcontinuüm, zoals weergegeven in figuur 1.1, laat ook zien dat palliatieve zorg zich uitstrekt tot de periode na het overlijden, wanneer de directe naasten nazorg geboden moet worden.

\subsubsection{Proactieve benadering}

Om tijdig te kunnen anticiperen op de toenemende behoefte aan palliatieve zorg, wordt door deskundigen in de palliatieve zorg vaak gepleit voor een proactieve

\section{Figuur 1.1 Het palliatieve zorgcontinuüm}

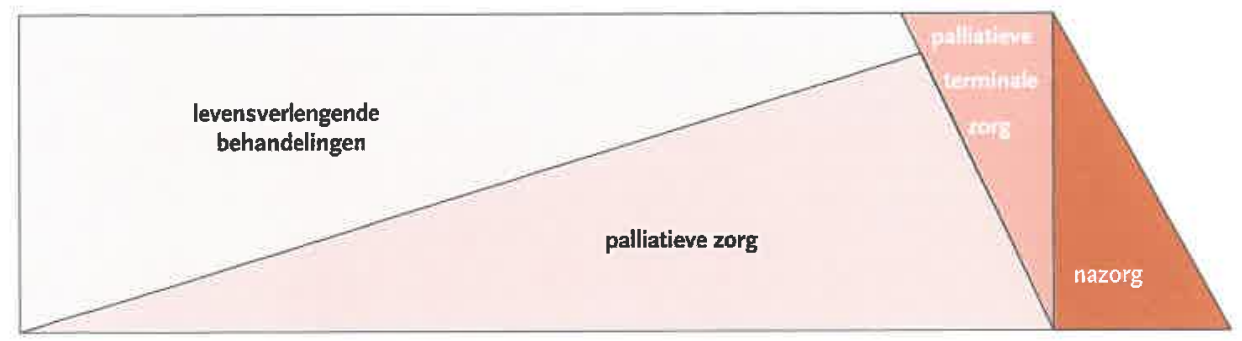


benadering, ook wel aangeduid met advance care planning. 3 Voor zorgverleners betekent dit dat zij al aan het begin van het zorgcontinuüm alert moeten zijn op veranderende problemen en behoeften bij de patiënt en directe naasten. Een proactieve benadering impliceert in de eerste plaats waakzaamheid van de zorgverlener; gespitstheid op wat de (veranderende) situatie van de patiënt aan zorg vraagt. Het gaat daarbij om rekening houden met wat patiënt en familie nu nodig hebben, maar ook wat zij in de toekomst mogelijk nodig zullen hebben.

In de praktijk wordt soms - onterecht - gedacht dat een proactieve benadering ook betekent dat al in een vroeg stadium alle mogelijke scenario's en te verwachten toekomstige problemen open besproken moeten worden met de patiënt en zijn familie. Daarvan kan alleen sprake zijn als de anderen er klaar voor zijn, als het bij hun beleving van de realiteit past.

\subsubsection{Conclusie}

Palliatieve zorg is een breed, veelomvattend begrip. Symptoomcontrole is een belangrijk element, maar zeker niet het enige. Belangrijk is ook de persoonlijke, warme aandacht en het alert zijn op - de soms snel veranderende - problemen en behoeften van patiënt en familie.

In de volgende hoofdstukken zullen veel van de elementen die in deze inleidende paragraaf zijn aangestipt, verder uitgewerkt worden, bijvoorbeeld het aanbod aan palliatieve zorg (hoofdstuk 2), de rol van de verpleegkundige in samenwerking met andere zorgverleners (hoofdstuk 3) en het overzicht van de belangrijkste aspecten van de palliatieve zorg (hoofdstuk 4).

\section{LITERATUUR}

1 www.who.int/cancer/palliative/definition.

2 Cannaerts, N., B. Dierckx de Casterlé \& M. Grypdonck. Palliatieve zorg. Zorg voor het leven. Academia Press, Leuven, 2000.

3 Lynn, J. \& D.M. Adamson. Living well at the end of life. Adapting health care to serious chronic illness in old age. Rand Health White Paper, Santa Monica, 2003.

4 Palliatieve zorg; de pioniersfase voorbij. Brief van de staatssecretaris van Volksgezondheid, Welzijn en Sport, mw. dr. J. Bussemaker, aan de voorzitter van de Tweede Kamer der Staten-Generaal. Ministerie van VWS, Den Haag, 7 juni 2007. 


\subsection{DE GESCHIEDENIS VAN DE PALLIATIEVE ZORG IN NEDERLAND}

\section{Rob Bruntink}

Nederland kent een unieke positie als het gaat om de ontwikkeling van palliatieve zorgverlening. Nederland was het eerste en is vooralsnog het enige land ter wereld waarin een discussie van bijna dertig jaar over het wettelijk mogelijk maken van euthanasie en hulp bij zelfdoding voorafging aan de ontwikkeling van palliatieve zorg. ${ }^{1,2}$ In verschillende andere landen binnen en buiten Europa, waaronder ook België, startten discussies over euthanasie en/of hulp bij zelfdoding pas nadat de palliatieve zorgverlening reeds in enige mate tot ontplooiing was gekomen, en dit vaak naar aanleiding van het overlijden van concrete patiënten.3.4 De ontwikkeling van palliatieve zorg in Nederland mag daarom niet los gezien worden van deze discussie over euthanasie en hulp bij zelfdoding. Alvorens daarop verder in te gaan, besteden we in paragraaf 1.2.1 aandacht aan de opkomst van de Nederlandse hospicebeweging, die erg bepalend geweest is voor de ontwikkeling van palliatieve zorg. Afsluitend zal de rol van de overheid belicht worden, die sinds 1996 een nadrukkelijk stimuleringsbeleid voert ten aanzien van palliatieve zorg.

\subsubsection{De Nederlandse hospicebeweging}

\section{Palliatieve zorgculturur}

De ontwikkelingen op het gebied van palliatieve zorg in Nederland zijn in gang gezet door de komst van hospices en bijna-thuis-huizen. De eerste voortekenen van wat later de Nederlandse hospicebeweging werd, zijn te traceren in het begin van de jaren tachtig van de vorige eeuw. Enkele pioniers hadden kennisgemaakt met het St. Christopher's Hospice in Londen van Dame Cicely Saunders of met hospices van haar collega's in Groot-Brittannië.5 Saunders, verpleegkundige én arts, zette een internationale hospicebeweging in gang, door in 1967 een hospice te openen. Daar realiseerde zij haar ideaal: aan terminale patiënten in een kleinschalige en rustige omgeving zorg verlenen die verder ging dan medische aandacht. Ook nietlichamelijke problemen, zoals op psychosociaal of spiritueel gebied, werden in de zorg betrokken.

Onder de pioniers die met (buitenlandse) hospices hadden kennisgemaakt, zatèn relatief veel verpleegkundigen, een enkele (verpleeghuis)arts en betrokkenen uit de christelijke zuil van de gezondheidszorg en de patiëntenverenigingen. Eén van deze pioniers, Pieter Sluis, destijds huisarts in Nieuwkoop, nam in 1984 het initiatief tot de oprichting van de Stichting dr. Elisabeth Kübler-Ross Nederland..$^{5}$ Deze stichting wilde haar ideeën over bewust sterven en verliesverwerking in Nederland bekendmaken. Ook priester Rob van Hellenberg Hubar zette zijn ervaringen in GrootBrittannië om in concrete daden. Hij richtte in 1987 de Stichting Elckerlijck op, een 
'stichting voor bewustwording rond sterven en leven'. Beide organisaties hadden in eerste instantie als doel de hospicegedachte te verspreiden, of, als onderdeel daarvan, een bewustwording op gang te brengen rondom het denken over leven en dood. Een folder van Elckerlijck uit die tijd zegt hierover: 'Het enige wat nog telt als het sterven nabij is, is de kostbare, resterende tijd goed en rustig samen door te brengen, om elkaar te troosten, om op een goede manier afscheid van elkaar te nemen. Maar vaak schiet dat er in onze jachtige samenleving bij in.'5 Eveneens essentieel voor de visie van beide stichtingen was dat zij het sterven als proces van innerlijke groei (voor zowel de patiënt als voor diens naaste omgeving) zagen. 'Onze laatste dagen,' zo meldde een brochure van Elckerlijck, 'zouden tot de meest waardevolle van ons leven kunnen behoren. Ze bieden ons de laatste kans om kennis over te dragen, afscheid te nemen, onverwerkte zaken af te maken, herinneringen na te laten, te genieten van het leven.' Met de oprichting van deze stichtingen ontstonden podia voor mensen die zich stoorden aan de medisch-technische dominantie in de zorg voor ongeneeslijk zieke patiënten. Er ontstond hierdoor het begin van een palliatieve zorgcultuur waarin sterven niet als het ultieme falen van de gezondheidszorg werd gezien, maar als een normale, bij het leven horende fase.

\section{Hospices}

Kortna de oprichting van de Stichting dr. Elisabeth Kübler-Ross startte Pieter Sluis in 1988 met enkele tientallen vrijwilligers het eerste hospice in Nederland: het bijna-thuis-huis in Nieuwkoop. ${ }^{5}$ Net zoals nu nog steeds regelmatig gebeurt, stond de buurt niet te springen om een dergelijk 'sterfhuis'. 'In het begin vroegen buurtbewoners zich af of ze hun kinderen wel rondom het huis konden laten spelen,' herinnert Pieter Sluis zich. 'Ze vonden het maar een eng idee, al die doodzieke mensen. Ook waren ze bang voor een grote hoeveelheid begrafenisstoeten door de straat.' Na verloop van tijd zakten de protesten in en sloeg de weerstand om in grote sympathie. Dit proces heeft zich de afgelopen decennia herhaaldelijk voorgedaan rondom de start van hospicevoorzieningen. Priester Van Hellenberg Hubar bewandelde andere wegen, maar ook zijn inzet, samen met die van het Leger des Heils, leidde tot de oprichting van een nieuw hospice: Rozenheuvel in Rozendaal. Het ging in 1994 van start. Van Hellenberg Hubar vroeg de internist-oncoloog Ben Zylicz als medisch directeur. Zylicz werkte tot dat moment in een ziekenhuis in Groningen, en liep al jarenlang rond met plannen om een hospice te openen. Hij was toen een van de weinige artsen in Nederland die zich in palliatieve zorg had gespecialiseerd. Een tekenende oneliner van Zylicz uit die tijd was dat alle palliatieve zorgdeskundigen in Nederland met zijn allen in één taxi pasten. Tegenwoordig zijn er tientallen bussen nodig om alle gespecialiseerde artsen te vervoeren.

De geschiedenis van de Nederlandse hospicebeweging is niet volledig als niet ook naar twee andere hospices wordt verwezen: Hospice Kuria in Amsterdam en het Johannes Hospitium in Vleuten. Beide hospices zijn in 1992 vanuit religieuze betrokkenheid ontstaan. Het initiatief voor het Amsterdamse hospice kwam van een 
aantal hervormde en gereformeerde kerken. Het hospice in Vleuten is opgericht met steun vanuit de Maltezer en Johanniter Orde. De hospices in Vleuten, Amsterdam en Rozendaal behoorden tot de eerste hospicevoorzieningen die later high-care hospices zouden worden genoemd.

\section{Vrijwilligerswerk}

De historie van de hospicebeweging is niet compleet als niet naar het pionierswerk van het georganiseerde vrijwilligerswerk wordt gekeken. In 1984 werd de Stichting Landelijke Samenwerking Terminale Zorg opgericht, de voorloper van de Landelijke Stichting Vrijwilligers Terminale Zorg (VTZ), die weer de voorloper was van de huidige vereniging Vrijwilligers Palliatieve Terminale Zorg (VPTZ). ${ }^{6}$ Vrijwilligers van de lokale VPTZorganisaties, die patiënten en naasten thuis ondersteunen, merkten in de praktijk dat er soms behoefte was aan een vervangend thuis, omdat er weinig mantelzorg was of omdat de mantelzorgers oververmoeid raakten. Zo ontstond een aantal VPTZ-organisaties met een hospice of bijna-thuis-huis erbij. Net zoals deze eerste hospicevoorzieningen uit de jaren negentig van de vorige eeuw, is een meerderheid van de in 2011 bestaande zelfstandige hospicevoorzieningen aangesloten bij de VPTZ. In totaal telt de VPTZ 204 (lokale en/of regionale) organisaties. Daar werken ongeveer 10.000 vrijwilligers.?

\subsubsection{Euthanasie}

De belangrijkste drijfveer voor de Nederlandse hospicepioniers was weliswaar de zorg voor stervenden verbeteren, maar er speelde, zoals hiervoor al aangehaald, in die tijd ook een andere kwestie mee. Enkele partijen (met name de religieus geïnspireerde initiatiefnemers) wilden een concrete daad stellen in de euthanasiediscussie die in Nederland in de jaren tachtig en negentig van de vorige eeuw volop leefde. Hospicearts Rita Plomp-van Harmelen bijvoorbeeld, die in de eerste jaren onder meer betrokken was bij het Johannes Hospitium in Vleuten, legde in een artikel in Pallium duidelijk het verband: 'De hospices zijn mede opgericht om tegenwicht te bieden aan die liberale golf van "euthanasie moet kunnen".'8 Dezelfde achtergrond gold ook voor Hospice Kuria in Amsterdam: 'Het hospice is mede opgericht als reactie op het Nederlandse euthanasiebeleid,' zei een bestuurslid. Achterliggende gedachte hierbij is dat de vraag om euthanasie verdwijnt als de palliatieve zorg goed ontwikkeld is. Omdat niet iedereen het daarmee eens is, is Nederland nog steeds het enige land ter wereld waarin twee soorten hospicevoorzieningen bestaan: voorzieningen waar euthanasie wel is toegestaan, en andere waar euthanasie niet wordt toegestaan. De scheiding staat symbool voor de visie op palliatieve zorgverlening: kan euthanasie daar wel of geen onderdeel van zijn? Ook daarover zijn de meningen in het land verdeeld. Uitgaand van de WHO-definitie over palliatieve zorg, waarin expliciet wordt gesteld dat de dood niet versneld wordt, neemt Nederland daarmee op wereldschaal gezien een uitzonderingspositie in (zie verder ook paragraaf 1.4 over beslissingen over het levenseinde). ${ }^{5}$ 


\subsubsection{Overheidsbeleid}

\section{Netwerken}

De opkomst van de hospices - die door particuliere organisaties, en dus buiten de reguliere zorg om, werden opgericht - viel ook de overheid op. Het betrokken ministerie, het ministerie van Volksgezondheid, Welzijn en Sport, wilde niet dat de hospices als eilandjes bleven voortbestaan. Het ministerie gaf daarom in 1998 een Projectgroep Integratie Hospicezorg de opdracht te onderzoeken hoe de hospicewereld in de organisatie van de reguliere gezondheidszorg kon worden ingepast. Het antwoord van de projectgroep, die onder leiding stond van P.A.C. Beelaerts van Blokland, was vooral: netwerkvorming. ${ }^{9}$ In regionale netwerken zouden alle partijen die op een of andere wijze bij palliatieve zorgverlening waren betrokken, waaronder de hospices, maar ook de verpleeg- en verzorgingshuizen, huisartsen, vrijwilligersorganisaties, ziekenhuizen en thuiszorgorganisaties, moeten samenwerken. Gezamenlijk zouden de partijen het doel moeten hebben de kwaliteit en het noodzakelijke aanbod van palliatieve zorg in een bepaalde regio te garanderen. Het advies werd door de overheid overgenomen, waardoor in korte tijd zo'n 6o-70 regionale netwerken palliatieve zorg ontstonden. Alle hospicevoorzieningen zijn bij een dergelijk netwerk aangesloten.

Overigens had niet alleen de overheid oog voor de opkomst van de hospices. Ook de reguliere zorg zag het gebeuren. Tientallen verpleeg- en verzorgingshuizen kopieerden als het ware het hospiceconcept naar hun eigen organisatie. Zo ontstonden er aparte afdelingen palliatieve zorg. Vaak ging het om afdelingen met slechts twee of drie bedden. Enige uitzondering daarop was het verpleeghuis AntoniusIJsselmonde in Rotterdam. Daar experimenteerde men al in de jaren tachtig met een aparte afdeling voor stervenden. ${ }^{10}$ Thuiszorgorganisaties kregen ook meer oog voor palliatieve zorg. Sommige organisaties raakten betrokken bij de oprichting van hospices. Andere richtten speciale teams op voor palliatieve patiënten. Met dank aan medisch-technische ontwikkelingen, konden patiënten die voorheen in het ziekenhuis moesten blijven, nu steeds vaker thuisblijven. Teams voor thuiszorgtechnologie werden daardoor ook noodzakelijk."

\section{Consultatieteams}

De overheid erkende in de laatste jaren van de vorige eeuw dat er ernstige kennistekorten bestonden op het gebied van palliatieve zorgverlening. De toenmalige minister van Volksgezondheid, Welzijn en Sport Els Borst stelde vanaf 1998 voor een periode van vijf jaar 7 miljoen gulden (omgerekend ruim $€$ 3,1 miljoen) per jaar beschikbaar voor onderzoek, onder meer naar de behoeften van mensen in de terminale fase. Ook werden van deze bedragen projecten uitgevoerd die de deskundigheid van zorgverleners moesten vergroten. ${ }^{12}$ De visie van minister Borst was dat palliatieve zorg geen specialistische zorg, maar generalistische zorg moest zijn. Ofwel: alle zorgverleners vooral alle artsen, verpleegkundigen en verzorgenden - die met palliatieve patiënten in 
contact zouden kunnen komen, zouden deze vorm van zorg moeten kunnen verlenen. Om dit mogelijk te maken, moest er voor hen - volgens de minister - wel een soort achterwacht gecreëerd worden, waar zorgverleners terecht konden in het geval zij op moeilijkheden stuitten bij de behandeling en begeleiding van deze patiënten. Daardoor ontstonden, in eerste instantie onder de vleugels van zes Centra voor Ontwikkeling van Palliatieve Zorg (COPZ), later onder verantwoordelijkheid van de integrale kankercentra (IKC), tientallen consultatieteams palliatieve zorg. ${ }^{12}$ Deze teams bestonden met name uit verpleegkundigen en artsen die gespecialiseerd waren in palliatieve zorg. Zij verlenen - telefonisch of aan het bed - adviezen aan de consultvragers over de behandeling en begeleiding van palliatieve patiënten.

\section{Structurele financiering}

In het overheidsbeleid is sinds de maatregelen van Els Borst weinig veranderd. De verantwoordelijke bewindspersonen, staatssecretaris Clémence Ross-van Dorp en Jet Bussemaker, vervolgden het beleid van hun voorganger. Jaarlijks reserveerden zij een vast bedrag voor de verdere stimulering van palliatieve zorg. In 2008 publiceerde laatstgenoemde staatssecretaris het Plan van Aanpak Palliatieve Zorg 2008-2010. Dit plan is samen met een aantal landelijke (koepel)organisaties op het gebied van palliatieve zorg ontwikkeld. In het plan werden de belangrijkste prioriteiten voor verbeteringen van de zorg opgesomd. Om de plannen uit te werken, stelde VWS jaarlijks bijna $€ 10$ miljoen extra ter beschikking. Bijna de helft werd bestemd voor het aandeel dat vrijwilligers leveren op het gebied van palliatieve zorg en de coördinatie van de netwerken palliatieve zorg, € 2 miljoen voor de huisvestingslasten van bijna-thuis-huizen en high-care hospices en $€$ 3,8 miljoen voor resterende actiepunten. Deze lagen met name op het terrein van de organisatie, de kwaliteit, het onderwijs en de deskundigheidsbevordering. ${ }^{13,14}$ De in 2010 aangestelde staatssecretaris Marlies Veldhuijzen van Zanten-Hyllner bevestigde de financiële afspraken.15

\section{Verbreding}

Onder het beleid van Jet Bussemaker werd gestart met het begin van de verbreding van de doelgroep van palliatieve zorg. Ging het tot dat moment vooral om mensen met kanker, nu werden ook mensen met andere ziektebeelden (zoals COPD, hartfalen en ALS) en speciale patiëntengroepen, zoals mensen met een verstandelijke handicap, kinderen, dementerenden en mensen met een psychische aandoening, in de beleidsstukken genoemd. ${ }^{4}$ Het betekende voor de afdelingen palliatieve zorg van de integrale kankercentra, die de ondersteuning van zorgaanbieders in de diverse regio's tot taak hadden gekregen, een flinke verschuiving van de aandacht. Immers, van oudsher waren zij uitsluitend gericht op mensen met kanker. Het signaal om de aandacht voor palliatieve zorg te verbreden naar andere doelgroepen was niet alleen gericht op zorgaanbieders, maar ook op patiënten- en/of belangenorganisaties. Eén van de partijen die het signaal het duidelijkst oppikte, was de Vereniging Ouders, Kinderen en Kanker (VOKK), die 
via het project Koesterkind aandacht vroeg voor kinderen die aan de gevolgen van kanker overlijden. ${ }^{16}$ Vooralsnog is het een van de weinige patiëntenbelangenorganisaties in Nederland die palliatieve zorg als aandachtsgebied heeft ontdekt.

Behalve op de verbreding in doelgroep zette Bussemaker zwaar in op de verbreding in tijd. Ging tot dusverre palliatieve zorg vooral over de terminale fase van de ziekte, volgens Bussemaker werd het nu tijd het startmoment van de palliatieve zorgverlening naar voren te halen: vanaf het moment dat er sprake was van een ongeneeslijke ziekte, zou palliatieve zorg onderdeel moeten zijn van de verleende. zorg. 'De uitdaging voor de toekomst is om ruimte te maken voor een nieuw zorgmodel, waarin curatieve zorg en palliatieve zorg meer gelijktijdig dan wel geleidelijk in elkaar overlopend georganiseerd zijn,' schreef zij in 2008 aan de Tweede Kamer. ${ }^{13}$ Of het de overheid lukt, overeenkomstig de WHO-definitie, palliatieve zorg uit de sfeer van de laatste levensfase te halen, zal de toekomst uitwijzen.

\section{Koepelorganisaties}

De diverse stromen aan activiteiten op het gebied van hospicezorg en palliatieve zorg in de jaren tachtig en negentig van de vorige eeuw leidden tot de behoefte aan een overkoepelende organisatie. In 1996 werd het Netwerk Palliatieve Zorg voor Terminale Patiënten Nederland (NPTN) opgericht. ${ }^{5}$ Het gros van de hospices en bijna-thuis-huizen dat in de pioniersfase was ontstaan, werd lid van deze vereniging. Ook thuiszorgorganisaties en ziekenhuizen sloten zich erbij aan. In 1988 had Pieter Sluis al een koepelorganisatie voor de bijna-thuis-huizen opgericht: de Nederlandse Hospice Beweging (NHB). De NHB is in 2001 opgevolgd door de Vereniging Vrijwilligers Hospicezorg Nederland (VHN). Deze is in 2005 opgegaan in de vereniging Vrijwilligers Palliatieve Terminale Zorg (VPTZ). Ook de Stichting Elckerlijck van Van Hellenberg Hubar sloot zich (in 2006) aan bij de VPTZ. De VPTZ was één van de initiatiefnemers voor het NPTN. Vanuit het NPTN ontstond in 2002 Agora, het landelijke ondersteuningspunt palliatieve terminale zorg. In opdracht van het ministerie van Volksgezondheid, Welzijn en Sport moet Agora als ondersteuningspunt een marktplaats voor zorgaanbieders zijn, die informatie en initiatieven uitwisselen op het terrein van palliatieve zorg. Behalve het stimuleren van die uitwisseling, afstemming en ontmoeting, zijn het verzamelen en beschikbaar stellen van kennis en het verzorgen van voorlichting(sbijeenkomsten) voor professionals de belangrijkste taken. In 2009 verwijderde Agora het woord 'terminale' uit de naam. In 2010 transformeerde het NPTN tot Palliactief, een beroepsorganisatie voor iedereen die (als professional) werkzaam is op het gebied van palliatieve zorg.

\subsubsection{Conclusie}

De ontwikkeling van palliatieve zorg in Nederland kan niet los gezien worden van de ontwikkeling van vrijwilligerszorg en hospicezorg voor terminale patiënten. Door initiatieven op dit gebied, ontstond ook in de reguliere gezondheidszorg een 
brede interesse voor palliatieve zorgverlening. Zowel intramuraal als extramuraal zijn sinds de jaren 1995-2000 tal van projecten, initiatieven en activiteiten opgezet, ter verbetering van de zorg voor ongeneeslijk zieke mensen. Sinds het begin van deze eeuw raakten hospicevoorzieningen in de reguliere gezondheidszorg ingebed, ontstonden consultatieteams palliatieve zorg en bundelden alle bij palliatieve zorg betrokken beroepsgroepen en instellingen hun krachten in (regionale) netwerken palliatieve zorg. Deze ontwikkelingen zijn voor een belangrijk deel te danken aan het stimuleringsbeleid palliatieve zorg dat het ministerie van Volksgezondheid, Welzijn en Sport heeft gevoerd.

\section{LITERATUUR}

1 Have, H. ten \& R. Janssens. Palliative care in Europe. IOS Press, Amsterdam, 2001.

2 Kennedy, J. Een weloverwogen dood. Euthanasie in Nederland. Bert Bakker, Amsterdam, 2002.

3 Lynne, D. Terri's Story: The court-ordered death of an American woman. Cumberland House, Naperville IL, 2005 .

4 Sampedro, R. Brieven uit de hel. Fondsgroep Geloof \& Praktijk, 2008.

5 Bruntink, R. Een goede plek om te sterven. Palliatieve zorg in Nederland. Een wegwijzer. Plataan, Zutphen, 2002.

6 www.vptz.nl. Geraadpleegd op 4 januari 2010.

7 Bruntink, R. Hans Bart, directeur Landelijk Steunpunt VPTV: Goede zorg komt van binnenuit. Pallium, 2002, 11(1), 28-30.

8 Bruntink, R. Hospice-arts Rita Plomp-van Harmelen: Palliatieve zorg met hoofdletter ' $\mathrm{C}$ '. Pallium, 2000, 2(3), 10-12

9 Verbetering van de zorg voor mensen in de terminale fase en hun naasten. Eindrapport. Projectgroep Integratie Hospicezorg, Voorburg, 2001.

10 Baar, F. Zorg voor stervenden in Antonius-IJsselmonde. Rotterdam, 1993.

11 Boxtel, T. van. Infuustechnologie in de palliatieve fase. Bohn Stafleu van Loghum, Houten, 2000.

12 Brieven van minister Els Borst van het ministerie van Volksgezondheid, Welzijn en Sport naar de Tweede Kamer. Ministerie van VWS, Den Haag, 21 december 2001 en 11 maart 2002.

13 Palliatieve zorg; de pioniersfase voorbij. Brief van de staatssecretaris van Volksgezondheid, Welzijn en Sport, mw. dr. J. Bussemaker, aan de voorzitter van de Tweede Kamer der StatenGeneraal. Ministerie van VWS, Den Haag, 7 juni 2007.

14 Plan van Aanpak Palliatieve Zorg 2008-2010. Ministerie van VWS, Den Haag, 2008.

15 Verankering van palliatieve zorg in de praktijk. Brief van de staatssecretaris van Volksgezondheid, Welzijn en Sport, mw. drs. M.L.L.E. Veldhuijzen van Zanten-Hyllner, aan de voorzitter van de Tweede Kamer der Staten-Generaal. Ministerie van VWS, Den Haag, 13 januari 2011.

16 Berg, M. van den. Op weg naar goede praktijken in de kinderpalliatieve zorg. Stichting Palliatieve Zorg voor Kinderen, Bunnik, 2009. 


\subsection{DE GESCHIEDENIS VAN DE PALLIATIEVE ZORG IN VLAANDEREN}

\section{Trudie van lersel}

De geschiedenis van de palliatieve zorg in Vlaanderen wordt gekenmerkt door drie periodes. In de jaren tachtig ontstaan de kiemen (hot spots) van palliatieve zorg, sterk gecentreerd rond bevlogen pioniers. De jaren negentig zijn de echte pioniersjaren waarin tal van initiatieven worden genomen en uitgewerkt en de structuur voor palliatieve zorgverlening zich uitkristalliseert. Het begin van de 21e eeuw luidt de professionalisering in: er komt meer structurele subsidiëring, men wordt erkend als gesprekspartner.

\subsubsection{Het begin in de jaren tachtig}

De palliatieve beweging ontstaat in Vlaanderen midden jaren tachtig van de vorige eeuw. Men realiseert zich dat de verregaande medisch-technologische mogelijkheden steeds vaker resulteren in goedbedoelde, ingrijpende therapeutische behandelingen gericht op genezing, terwijl de realiteit van een naderend sterven onvoldoende wordt onderkend. In navolging van de initiatieven van de hospicebeweging van dr. Cecily Saunders in Engeland (zie paragraaf 1.2.1) ontstaan er verspreid over Vlaanderen kleine particuliere initiatieven van artsen, verpleegkundigen en verzorgenden die zich - meestal in hun vrije tijd - richten op de verzorging en begeleiding van terminale patiënten. Veel van deze begeleidingen vinden thuis plaats nadat de 'uitbehandelde' patiënt het ziekenhuis heeft verlaten. De eerste georganiseerde palliatieve thuiszorgdienst in Vlaanderen is Intensieve Zorgen Thuis, opgericht in 1987 door $\mathrm{dr}$. Arsène Mullie in Brugge. Nadat op nog enkele plaatsen initiatieven voor palliatieve thuiszorg zijn ontstaan, verenigt men zich op initiatief van Lisette Custermans in 1990 in de Federatie Terminale Zorg Vlaanderen die in 1993 de naam wijzigt in Federatie Palliatieve Zorg Vlaanderen.

\subsubsection{De pioniersjaren in de jaren negentig}

In de jaren negentig zijn de belangrijkste doelstellingen van de federatie het sensibiliseren van artsen en andere zorgverleners voor een tijdige overschakeling van curatieve naar palliatieve behandelingen en het ontwikkelen van palliatieve zorg als specifieke discipline binnen de gezondheidszorg. Voor beide zaken heeft men de steun van de overheid nodig en een sterke lobby komt op gang voor de erkenning en financiering van palliatieve dienstverlening. In 1991 slaagt men erin om de federale minister van Sociale Zaken Philippe Busquin te overtuigen van het belang van palliatieve thuiszorg en worden in België acht (waarvan vijf in Vlaanderen) palliatieve thuiszorgequipes erkend en gefinancierd via een experimentele subsidie. De financiering is beperkt en een groot deel van het werk van deze equipes gebeurt door vrijwilligerswerk. De experimentele financiering wordt jaarlijks verlengd totdat in 
1998 verspreid over heel Vlaanderen vijftien erkende palliatieve thuiszorgequipes worden opgericht en gesubsidieerd. Ondertussen breiden de initiatieven voor palliatieve ondersteuning in Vlaanderen zich uit naar de ziekenhuissector waar op dat moment nog $75 \%$ van de sterfgevallen plaatsvindt. In 1990 richt zuster Leontine (dr. J. de Buysscher), na haar pensionering als algemeen directeur van het algemeen ziekenhuis Sint-Jan in Brussel, de eerste Vlaamse palliatieve zorgeenheid op. Deze eenheid, die verbonden is aan het Sint-Jan-ziekenhuis, beschikt over twaalf bedden specifiek voor palliatieve patiënten die een (geschatte) maximale overlevingsduur van drie maanden hebben. Andere ziekenhuizen volgen haar voorbeeld en richten hun eigen palliatieve zorgeenheid op. De eerste palliatieve supportteams in de ziekenhuizen ontstaan vanaf 1991 . Het zijn mobiele equipes die palliatieve patiënten en ziekenhuispersoneel ondersteunen. Zowel de palliatieve zorgeenheden als de palliatieve supportteams zijn tot 1997 voor hun financiering afhankelijk van de goodwill van hun ziekenhuis en ook zij draaien grotendeels op vrijwilligers. In 1997 krijgen de palliatieve zorgeenheden en de palliatieve supportteams van de overheid een formeel statuut, de financiering van de palliatieve supportteams laat echter tot $2001 \mathrm{op}$ zich wachten.

Op Vlaams niveau realiseert minister van Welzijn Wivina Demeester in 1994 via een beleidsprogramma palliatieve zorg het recht van patiënten op palliatieve zorg.' Demeester onderkent het belang van vrijwilligerswerk binnen de palliatieve zorg en vertaalt dit in het decreet op georganiseerd vrijwilligerswerk (1994). In het beleidsprogramma van Demeester wordt mede op advies van de Federatie Palliatieve Zorg Vlaanderen aan de laatste belangrijke facetten invulling gegeven. Ten eerste worden met het oog op coördinatie en afstemming van palliatieve zorg in 1995 voor heel Vlaanderen vijftien 'netwerken voor palliatieve zorg' in het leven geroepen; erkenning van deze netwerken op federaal niveau als 'samenwerkingsverbanden palliatieve zorg' volgt in 1997. Daarnaast wordt in 1997 ook de palliatieve ondersteuning in de residentiële ouderenzorg geregeld. Op initiatief van de palliatieve beweging zelf worden ten slotte vanaf het eind van de jaren negentig de eerste palliatieve dagcentra opgericht ter ondersteuning van de thuiszorg. De overheid volgt in 2002 met een voorzichtige experimentele financiering van enkele dagcentra via het Rijksinstituut voor Ziekte- en Invaliditeitsverzekering (RIZIV). Hiermee is het plaatje van het palliatief landschap compleet.

\subsubsection{Professionalisering aan het begin van de 21 e eeuw}

De overheidsinitiatieven resulteren in 2000 voor het eerst in een overkoepelend palliatief beleidsplan van de ministers Magda Aelvoet en Frank Vandenbroucke, waarin door middel van een verhoging van de budgetten een versterking van de palliatieve cultuur in heel België wordt nagestreefd. ${ }^{2}$ In heel Vlaanderen zijn voorzieningen voor palliatieve zorg geïnstalleerd en elke palliatieve patiënt in Vlaanderen kan hiervan gebruikmaken. In 2002 wordt de Wet betreffende de palliatieve zorg van kracht 
waarin het recht van elke patiënt op adequate palliatieve zorg wettelijk wordt geregeld. ${ }^{3}$ Een van de maatregelen die in deze wet is vastgelegd, is de oprichting van een Federale Evaluatiecel Palliatieve Zorg die de kwaliteit van de palliatieve zorgverlening evalueert en aanbevelingen ter verbetering van palliatieve zorg doet aan de wetgevende Kamers. Onder voorzitterschap van prof.dr. Manu Keirse verschijnt in 2005 een eerste rapport; een tweede evaluatierapport met voorstellen en aanbevelingen om de kwaliteit van palliatieve zorg in België te handhaven en te verbeteren verschijnt in 2008.4

Mede op basis van de aambevelingen van de evaluatiecel neemt het beschikbare federale budget voor palliatieve zorgverlening tussen 2002 en 2008 toe met ruim $50 \%$. Voor de sector zelf ontstaat er als gevolg van de toenemende professionalisering en structurele financiering een grotere druk op het afleggen van verantwoording, toenemende regelgeving en administratie en de verplichting om te voldoen aan duidelijk omschreven erkenningsvereisten en registratie van activiteiten en patiëntgegevens.

\subsubsection{Overheidsbeleid met betrekking tot palliatieve zorg}

Het overheidsbeleid werd voor het eerst vastgelegd in het beleidsprogramma van Wivina Demeester in 1994.' Vanaf het eerste moment was het beleid erop gericht dat mensen thuis moesten kunnen sterven: voorzieningen moesten hierop worden afgestemd - palliatieve thuiszorg is prioritair. Dit heeft ertoe geleid dat in Vlaanderen in elke regio een multidisciplinaire palliatieve thuiszorgequipe actief is, een situatie die uniek is in internationaal verband. Een tweede prioriteit voor de overheid is dat palliatieve zorg beschikbaar dient te zijn voor iedereen die hieraan behoefte heeft, ongeacht waar men zich bevindt, in welke financiële situatie men verkeert en welke levensovertuiging men aanhangt. Het gevolg van dit uitgangspunt is dat er in Vlaanderen een geografisch dekkende structuur voor eerstelijns en tweedelijns palliatieve gezondheidszorg is opgezet: in elke regio kan men de ondersteuning vragen van een multidisciplinaire thuiszorgequipe, elk ziekenhuis dient te beschikken over een palliatief supportteam en in elk rust- of verzorgingstehuis kan men een beroep doen op een palliatief verpleegkundige of een palliatief supportteam. Palliatieve zorgverlening wordt bovendien via de ziekenfondsen vergoed door het RIZIV. Ten slotte heeft de overheid ervoor gekozen dat palliatieve zorgverlening geïntegreerd dient te zijn in de reguliere gezondheidszorg. Hier hebben de netwerken voor palliatieve zorg en de multidisciplinaire palliatieve thuiszorgequipes een belangrijke taak gekregen. De opdracht van de netwerken is (onder meer) het bevorderen van de samenwerking op het gebied van palliatieve zorg tussen de reguliere gezondheidszorginstellingen in een regio (ziekenhuis, thuiszorg, residentiële ouderenzorg). De multidisciplinaire palliatieve thuiszorgequipes op hun beurt hebben de opdracht om de eerstelijnsgezondheidszorg (huisarts, thuisverpleegkundige, paramedici) te ondersteunen bij de begeleiding van een palliatieve patiënt, het is dan ook niet de bedoeling dat deze equipes zelf de zorg overnemen. 


\section{T.3.5 Het beleid van de Federatie Palliatieve Zorg Vlaanderen}

De Federatie Palliatieve Zorg Vlaanderen is het overkoepelende orgaan voor organisaties en zorgverleners die zich richten op palliatieve zorgverlening. Aangezien de federatie vanaf het begin van haar bestaan nauwe banden onderhield met politici en overheidsdiensten, is het niet verwonderlijk dat de beleidsprioriteiten van de federatie dezelfde zijn als die van de overheid: thuiszorg is prioritair, palliatieve zorg dient beschikbaar te zijn voor iedereen en dient geïntegreerd te zijn in de reguliere gezondheidszorg. Via een vijfentwintigtal overleggroepen rond een thema, discipline of setting tracht de federatie invulling te geven aan deze beleidsprioriteiten. ${ }^{5}$ Naast de genoemde prioriteiten vormt de handhaving en verbetering van de kwaliteit van palliatieve zorgverlening een belangrijk aandachtspunt. Kwaliteit van zorg is enerzijds afhankelijk van de deskundigheid van de zorgverlener, anderzijds van de beschikbare wetenschappelijk onderbouwde kennis over de zorgverleningsprincipes. Beide aspecten vormen een prioriteit in het beleid van de federatie. Vanaf het begin van haar bestaan aan het begin van de jaren negentig richt de Federatie Palliatieve Zorg Vlaanderen zich op deskundigheidsbevordering van zorgverleners (inclusief vrijwilligers) en wordt jaarlijks een vormingsprogramma aangeboden. De laatste jaren wordt het vormingsprogramma opgesteld in samenwerking met de netwerken waarbij de netwerken de basisopleidingen verzorgen voor hun regio en de federatie zich toelegt op meer gespecialiseerde vorming. De aandacht voor wetenschappelijk onderbouwde zorgverlening leidt in toenemende mate tot het stimuleren en ondersteunen van praktijkgerichte onderzoeksprojecten zoals het ontwikkelen van zorgpaden en richtlijnen voor zorg.

Op maatschappelijk gebied streeft de federatie de sensibilisatie na van de Vlaamse bevolking over de mogelijkheden van goede levenseindezorg. Een recent ontwikkeld hulpmiddel hiervoor is de 'Wilsverklaring', een document waarin patiënten in een vroegtijdig stadium kunnen aangeven welke wensen zij hebben met betrekking tot de zorg aan het levenseinde.

De mogelijkheid voor patiënten om sinds het in werking treden in 2002 van de Wet betreffende de euthanasie een arts om euthanasie te vragen, was aanleiding voor de federatie om een visie te ontwikkelen over de relatie tussen palliatieve zorg en euthanasie. ${ }^{6}$ Hoewel euthanasie strikt gezien niet wordt gezien als een onderdeel van palliatieve zorg, blijft de federatie trouw aan haar principe van totaalzorg voor de palliatieve patiënt, ook als in uitzonderlijke gevallen een patiënt kiest voor euthanasie. Een belangrijke prioriteit voor de federatie ten slotte is het contact met overheidsorganisaties. Als spreekbuis van de palliatieve zorgverlener en de palliatieve patiënt behartigt zij de belangen van beiden door rechtstreeks of indirect via de evaluatiecel bij de overheid de noden aan te kaarten op het gebied van zorgverlening en financiering.

\subsubsection{Regelgeving van palliatieve zorg in Vlaanderen}

Deze paragraaf geeft een samenvatting van de belangrijkste regelgeving met betrekking tot palliatieve zorg, zowel wat betreft de zorgverlening en ondersteuning, als wat 
betreft de patiënt en zijn naasten. Alle informatie over concrete wet- en regelgeving is terug te vinden op de website van de Federatie Palliatieve Zorg Vlaanderen.5 Het Evaluatierapport palliatieve zorg uit 2008 van de Federale Evaluatiecel Palliatieve Zorg plaatst de wet- en regelgeving rond palliatieve zorg in een groter geheel. 4

\section{Thuiszorg}

De vijftien Vlaamse palliatieve thuiszorgequipes hebben een overeenkomst afgesloten met het RIZIV waarin de omvang en de samenstelling van de equipe bepaald wordt op basis van het inwoneraantal van het werkingsgebied. De financiering vindt plaats per patiëntenbegeleiding; het aantal patiëntenbegeleidingen dat per jaar gefinancierd wordt is gebonden aan een maximum (Koninklijk Besluit, 13 oktober 1998). Voor de huisartsen bestaat er een specifieke nomenclatuur voor een huisbezoek aan een palliatieve patiënt waarin een vergoeding bepaald wordt die enigszins hoger is dan voor een gewoon huisbezoek en die alleen geldt met betrekking tot patiënten aan wie het palliatief statuut werd toegekend (Koninklijk Besluit, 19 juni 2002). Thuisverpleegkundigen die een palliatieve patiënt verzorgen, kunnen eveneens gebruikmaken van een specifiek nomenclatuurnummer mits zij voldoen aan bepaalde voorwaarden met betrekking tot onder meer de verzorging van de patiënt, en indien het een patiënt betreft aan wie het palliatief statuut werd toegekend (Koninklijk Besluit, 12 september 2001). Ook bestaat er voor kinesitherapie een palliatieve toeslag op de vergoeding voor thuisbehandeling van patiënten aan wie het palliatief statuut werd toegekend (Koninklijk Besluit, 1 juli 2006).

\section{Instituten}

Een aantal palliatieve dagcentra werd tussen 2002 en 2005 binnen een experimenteel project gefinancierd door het RIZIV en tussen 2006-2008 door de Vlaamse Gemeenschap. Besluitvorming over het al dan niet erkennen, normeren en financieren van palliatieve dagcentra wordt in 2011 verwacht. Rust- en verzorgingstehuizen moeten beschikken over een palliatieve functie (Koninklijk Besluit, 15 juli 1997) die zich richt op het sensibiliseren, ondersteunen en bijscholen van het personeel op het vlak van palliatieve zorg. Elk ziekenhuis dient te beschikken over een palliatief supportteam, waarvan de normen en erkenningvereisten vastliggen (Koninklijke Besluiten, 15 juli 1997, 19 april 1999). Financiering van deze supportteams volgde pas in 2001. Verder zijn er binnen de Vlaamse ziekenhuizen in totaal 209 bedden erkend voor palliatieve zorg, verdeeld over 29 palliatieve zorgeenheden met minimaal zes en maximaal twaalf bedden (Koninklijk Besluit, 15 juli 1997). De financiering wordt geregeld via de ligdagprijs (Koninklijk Besluit, 15 juli 1997).

\section{Organisatie palliatieve zorg}

Erkenning en subsidiëring van de vijftien Vlaamse netwerken/samenwerkingsverbanden is vastgelegd bij ministerieel besluit van 3 mei 1995 en Koninklijk Besluit van 
19 juni 1997. Subsidiëring is gebaseerd op het aantal inwoners van de regio die het netwerk/samenwerkingsverband bestrijkt en komt deels van de Vlaamse Gerneenschap, deels van de Federale Overheidsdienst Volksgezondheid, Veiligheid van de Voedselketen en Leefmilieu. Aan elk netwerk/samenwerkingsverband zijn ten minste een netwerkcoördinator en een klinisch psycholoog verbonden, het personeel dient jaarlijks te voldoen aan vastgelegde opleidingsvereisten. De Federatie Palliatieve Zorg Vlaanderen profileert zich als kennis- en expertisecentrum palliatieve zorg en ontvangt subsidie op basis van een convenant dat telkens voor drie jaar met de Vlaamse Gemeenschap wordt afgesloten. Het convenant omvat een aantal opdrachten die de federatie in de desbetreffende convenantperiode dient te volbrengen. Erkenning en subsidiëring van georganiseerd vrijwilligerswerk wordt geregeld door het decreet van 23 maart 1994.

\section{Patiënten en naasten}

Het Koninklijk Besluit van 2 december 1999 omschrijft aan welke criteria een patiënt dient te voldoen voor het toekennen van het palliatief statuut. Een aanvraag voor het palliatief statuut wordt door de huisarts gedaan. Het palliatief statuut geeft de patiënt recht op het palliatief zorgforfait, zijnde een tegemoetkoming in de kosten voor geneesmiddelen, verzorgingsmiddelen en hulpmiddelen ter hoogte van maximaal $€ 589,31$ voor een maand, hoogstens voor een maand te verlengen, en op het wegvallen van het persoonlijk aandeel ('remgeld') van de patiënt bij thuisverpleging, huisartsbezoek en kinesitherapiebehandelingen (Koninklijke Besluiten, 2 december 1999, 19 juni 2002, 12 september 2001, 1 juli 2006). Begeleiding door een multidisciplinaire palliatieve thuiszorgequipe is volledig gratis voor de patiënt (Koninklijk Besluit, 13 oktober 1998).

Voor de palliatieve dagopvang is er geen regelgeving voor de bijdrage van de patiënt. De meeste palliatieve dagcentra rekenen een bijdrage in de onkosten vergelijkbaar met die in de geriatrische dagopvang. Ook in de residentiële ouderenzorg zijn voor de bewoner geen kosten verbonden voor ondersteuning door een palliatief referent of supportteam. De ondersteuning door een palliatief supportteam in een ziekenhuis brengt voor de patiënt evenmin extra kosten mee en een opname op een palliatieve zorgeenheid wordt door de meeste ziekenfondsen vergoed, vaak wel mits de patiënt een aanvullende hospitalisatieverzekering heeft. Indien een palliatieve patiënt desondanks onvoldoende verzekerd blijkt te zijn voor deze toeslag, wordt hiervoor meestal wel een oplossing gevonden binnen het ziekenhuis waarvan de palliatieve zorgeenheid deel uitmaakt. Ter ondersteuning van een thuisverblijvende nabestaande in de palliatieve fase is er de mogelijkheid voor een werknemer om voor maximaal twee maanden palliatief zorgverlof op te nemen (Koninklijk Besluit, 22 maart 1995) met een werkonderbrekingsuitkering van $€ 726,85$ per maand. Tot slot is het nog belangrijk te vermelden dat er sinds 2002 in België ook een Wet betreffende de palliatieve zorg bestaat. ${ }^{3}$ Deze bepaalt dat elke patiënt recht heeft op palliatieve zorg bij de begeleiding van het levenseinde. 


\subsubsection{Conclusie}

Palliatieve zorg ontwikkelde zich in België aan het eind van de jaren tachtig van de vorige eeuw. In tien jaar tijd werd een structuur voor zorgverlening en coördinatie van zorg uitgebouwd waardoor iedereen in België een beroep kan doen op palliatieve zorgverlening. Het recht op palliatieve zorg werd in 2002 vastgelegd in een wet. ${ }^{3}$ Hoewel de prioriteit van zowel de overheid als de Federatie Palliatieve Zorg Vlaanderen ligt bij het thuis sterven, zijn ook in alle andere settings van zorg palliatieve teams opgericht. De kosten van palliatieve zorgverlening worden vergoed door de ziektekostenverzekeringen. De overheid voorziet verder in de mogelijkheid voor naasten van een palliatieve patiënt om palliatief verlof op te nemen. Voor deze vorm van loopbaanonderbreking is een beperkte vergoeding beschikbaar.

\section{LITERATUUR}

1 Demeester, W. Beleidsnota. Palliatieve zorg: een recht op een kwaliteitsvolle stervensbegeleiding. Ministerie van Welzijn, Brussel, 1994.

2 Vandenbroucke, F. Beleidsplan palliatieve zorg. Ministerie van Welzijn, Brussel, 2000.

3 Wet betreffende de palliatieve zorg 14 juni 2002. Belgisch Staatsblad, Brussel, 2002.

4 Federale Evaluatiecel Palliatieve Zorg. Evaluatierapport palliatieve zorg. Federale Overheidsdienst

Volksgezondheid, Veiligheid van de Voedselketen en Leefmilieu, Brussel, 2008.

5 www.palliatief.be.

6 Wet betreffende de euthanasie 22 mei 2002. Belgisch Staatsblad, Bnussel, 2002. 


\subsection{BESLISSINGEN AAN HET LEVENSEINDE EN DE ROL VAN VERPLEEGKUNDIGEN}

\section{Johan Bilsen}

De zorg voor ongeneeslijk zieke patiënten plaatst zorgverleners vaak voor ingrijpende beslissingen aan het levenseinde. Dit zijn moeilijke beslissingen die zorgvuldig moeten worden afgewogen door alle betrokken zorgverleners in nauw overleg met de patiënt en zijn naasten. De arts draagt de eindverantwoordelijkheid voor deze beslissingen, maar verpleegkundigen spelen een belangrijke rol in de besluitvorming en uitvoering. Deze paragraaf belicht kort de verschillende typen van beslissingen aan het levenseinde en hun regelgeving. Er wordt ook een aantal aandachtspunten gegeven met betrekking tot de rol van de verpleegkundigen bij deze beslissingen.

\subsubsection{Verschillende soorten van beslissingen aan het levenseinde}

Zorgverleners kunnen uiteenlopende beslissingen aan het levenseinde van patiënten nemen. Meestal zijn ze gericht op een verbetering van de algemene toestand en levenskwaliteit. Vaak, maar niet altijd, hebben ze ook gevolgen voor de resterende levensduur van de patiënt. In sommige gevallen zijn ze echt bedoeld om het levenseinde te bespoedigen. Er bestaan verschillende opvattingen over in hoeverre deze laatste beslissingen gericht op het bespoedigen van het levenseinde al dan niet deel uitmaken van palliatieve zorg (zie hiervoor paragrafen 1.1 en 1.3.5). Hoe dan ook zullen verpleegkundigen bij zorg aan het levenseinde ook geregeld met dit soort beslissingen geconfronteerd worden. Vandaar dat ze hier ook aan bod komen. In grote lijnen kan men de volgende typen van beslissingen aan het levenseinde onderscheiden., ${ }^{1,2}$

\section{Al dan niet afzien van een behandeling}

In de eerste plaats zijn er vele beslissingen aan het levenseinde die gericht zijn op het tijdelijk proberen te keren of af te remmen van het ziekteproces. Denk bijvoorbeeld aan chemo- of radiotherapie bij ongeneeslijke kanker. Deze beslissingen zijn meestal levensverlengend. Ze zijn enkel verantwoord wanneer de behandeling een reële kans op verbetering biedt en de voordelen ervan opwegen tegen de ermee samenhangende nadelen. De patiënt moet ook steeds vooraf duidelijk geïnformeerd worden en zijn toestemming geven voor de behandeling. ${ }^{.}$Wanneer de behandeling wordt opgestart of voortgezet, ook als ze niet doeltreffend en zinvol meer is, kan dit leiden tot therapeutische hardnekkigheid.

Daarnaast zijn er de niet-behandelbeslissingen. Hier makt de zorgverlener de keuze een behandeling niet (meer) op te starten of een lopende behandeling stop te zetten. Denk bijvoorbeeld aan het besluit om een acute longontsteking niet meer met antibiotica te behandelen of om een kunstmatige beademing stop te zetten. Meestal gebeurt dit omdat de behandeling geen verbetering meer geeft, of omdat 
de patiënt de behandeling weigert. Veelal zal men hierdoor de resterende levensduur van de patiënt verkorten. Het niet reanimeren wordt soms ook op voorhand vastgelegd in zogenoemde DNR-codes (do not resuscitate of niet-reanimeercodes). Niet-behandelbeslissingen aan het levenseinde van patiënten komen momenteel ongeveer in één op de drie sterfgevallen voor in Nederland en Vlaanderen en worden algemeen beschouwd als normaal medisch handelen. ${ }^{3,4}$

\section{Pijn-en andere symptoombestrijding}

Hieronder verstaan we het toedienen van medicatie in gepaste dosering en vorm om pijn en andere symptomen zoals benauwdheid of onrust op een adequate wijze te controleren. Pijn- en andere symptoombestrijding komen bijna steeds in de een of andere vorm voor aan het levenseinde van patiënten. Het zijn belangrijke onderdelen van palliatieve zorg omdat ze rechtstreeks bijdragen aan de levenskwaliteit voor de patiënt. Rond pijnbestrijding is veel expertise opgebouwd en men is het er momenteel over eens dat vrijwel alle pijn met aangepaste dosering en combinaties van de juiste pijnstillers kan worden verlicht (zie verder paragraaf 4.1). Bovendien zal adequate pijnbestrijding, met kennis van zaken uitgevoerd, zelfs bij gebruik van hoge doses van zware medicatie zoals morfine slechts in uitzonderlijke gevallen een levensverkortend neveneffect hebben. Toch geven Nederlandse en Vlaamse artsen in ongeveer één op de drie sterfgevallen te kennen dat ze intensieve pijnbestrijding toepasten, waarbij ze rekening hielden met een eventueel levensverkortend effect voor de patiënt.3.4 Men kan zich afvragen in welke mate het levensverkortend effect van morfine hier misschien wordt overschat. Een dergelijke overschatting kan ook aan de basis liggen van wat men morfinefobie noemt (angst om een voldoende hoge dosis morfine te gebruiken) en kan ertoe leiden dat patiënten niet de best mogelijke pijnbestrijding krijgen. Indien uitgevoerd volgens de regels van de kunst en na de geïnformeerde toestemming van de patiënt, worden adequate pijn- en symptoombestrijding net zoals de niet-behandelbeslissingen gerekend tot het normaal medisch handelen.

\section{Palliatieve sedatie}

In uitzonderlijke gevallen kunnen de pijn en de symptomen van de patiënt zo hardnekkig zijn dat zelfs de meest gespecialiseerde deskundigen ze met de normale medicamenteuze therapie niet meer onder controle krijgen. Men spreekt hier ook van refractaire symptomen. Bij die patiënten kunnen zorgverleners beslissen om het bewustzijn doelbewust en met gepaste sedativa te verlagen tot een niveau waarop deze symptomen niet meer worden waargenomen. Palliatieve sedatie kan mild of diep zijn, continu tot aan het overlijden of met tussenpozen van ontwaken. Men kan ervoor kiezen om al dan niet kunstmatig vocht en voeding toe te dienen. Bij 
onthouding van vocht en voeding kan er sprake zijn van een mogelijk levensverkortend effect voor de patiënt door dehydratatie. In de andere gevallen van een adequaat uitgevoerde palliatieve sedatie zal het levensverkortend effect nihil of gering zijn. Gezien de bewusteloosheid waarin de patiënt zich bevindt is het zeer wenselijk de verschillende aspecten van deze praktijk van tevoren en op tijd met de betrokken patiënt en zijn familieleden te bespreken. In Nederland bestaat er sinds 2005 een landelijke richtlijn palliatieve sedatie, die onder andere stelt dat deze praktijk slechts kort voor het overlijden toegepast mag worden, bij voorkeur met onthouding van vocht en voeding en met gebruik van benzodiazepinen. ${ }^{5}$ In Vlaanderen bestaat sinds januari 2011 een gelijkaardige richtlijn palliatieve sedatie. ${ }^{6}$ Palliatieve sedatie is vooral in de laatste jaren toegenomen en komt momenteel in Nederland in ongeveer één op de vijftien sterfgevallen voor en in Vlaanderen in één op de zeven sterfgevallen.3.4 Indien correct toegepast behoort deze praktijk eveneens tot het normaal medisch handelen.

\section{Het gebruik van levensbeëindigende middelen}

Het gebruik van levensbeëindigende middelen heeft per definitie de bedoeling het overlijden van de patiënt te bewerkstelligen. Het achterliggende motief is vaak een einde maken aan het uitzichtloze, onomkeerbare lijden van de patiënt. Dergelijke praktijken zijn in principe strafbaar, tenzij deze op basis van hiervoor speciaal in het leven geroepen wetten en regelgeving worden toegestaan. Afhankelijk van wie de middelen toedient en of dit al dan niet op uitdrukkelijk verzoek van de patiënt gebeurt, maakt men onderscheid tussen drie vormen: euthanasie, hulp bij zelfdoding en levensbeëindiging zonder uitdrukkelijk verzoek van de patiënt.

\section{Euthanasie}

In dit geval worden de levensbeëindigende middelen op uitdrukkelijk verzoek van de patiënt door de zorgverlener toegediend. In Nederland en België is euthanasie wettelijk toegestaan sinds de inwerkingtreding van een euthanasiewet in 2002.7 Hierin staan de verschillende zorgvuldigheidsvereisten waaraan voldaan moet zijn voordat euthanasie mag worden uitgevoerd. Euthanasie mag alleen uitgevoerd worden door een arts. Er moet een uitdrukkelijk, vrijwillig en weloverwogen verzoek van de patiënt zijn (in België ook herhaald en schriftelijk). In België moet de patiënt meerderjarig zijn, in Nederland is er ook een regeling uitgewerkt voor minderjarigen van ouder dan 12 jaar. De patiënt moet zich in een medisch uitzichtloze toestand bevinden met een ondraaglijk lijden, dat niet op een andere manier gelenigd kan worden. De patiënt moet voldoende ingelicht worden over zijn toestand en de vooruitzichten. De arts moet vooraf ten minste één andere onafhankelijke arts consulteren voor advies over de ziektetoestand en het euthanasieverzoek van de patiënt. 
Wat betreft de rol van verpleegkundigen, vermeldt uitsluitend de Belgische wet dat de arts overleg moet plegen met het verpleegkundig team als dit betrokken was bij de verzorging van de patiënt. De uitgevoerde euthanasie moet gemeld worden aan een controlecommissie, die beoordeelt of alle zorgvuldigheidsvereisten zijn nageleefd, en bij ingebrekestelling eventueel kan doorverwijzen naar de gerechtelijke instanties. In België zijn ook specifieke regels uitgewerkt die het mogelijk maken euthanasie op basis van een voorafgaande wilsbeschikking uit te voeren bij patiënten die in een onomkeerbaar coma zijn terechtgekomen. Momenteel komt euthanasie in Nederland en Vlaanderen in ongeveer één op de vijftig sterfgevallen voor. ${ }^{3,4}$

\section{Hulp bij zelfdoding}

In dit geval neemt de patiënt de levensbeëindigende middelen zelf in. De hulp van de zorgverlener beperkt zich tot het voorschrijven of bezorgen van de middelen aan de patiënt. In Nederland wordt deze praktijk op dezelfde wijze en in dezelfde wet geregeld als euthanasie. ${ }^{7}$ In België is hulp bij zelfdoding niet opgenomen in de euthanasiewet en blijft het onduidelijk in welke mate de hulpverlener al dan niet vervolgd kan worden (bijvoorbeeld op basis van nalatigheid door het niet helpen van een persoon in nood). De Belgische controlecommissie voor euthanasie beoordeelt de gemelde gevallen van hulp bij zelfdoding op dezelfde manier als euthanasie, op voorwaarde dat de patiënt de levensbeëindigende middelen heeft ingenomen onder permanente begeleiding van een arts, die kan ingrippen wanneer er iets mis zou gaan. Hulp bij zelfdoding is een praktijk die zowel in Nederland als in Vlaanderen momenteel zeer zelden voorkomt, namelijk respectievelijk in $0,1 \%$ en $0,07 \%$ van alle sterfgevallen. ${ }^{3 \cdot 4}$

\section{Levensbeëindiging zonder uitdrukkelijk verzoek van de patiënt}

In dit geval worden de levensbeëindigende middelen door de hulpverlener toegediend zonder dat de patiënt er uitdrukkelijk om verzocht heeft. Het gaat hier meestal over patiënten die zich door hun vergevorderd ziektestadium in een toestand van grote ontreddering bevinden, gepaard gaande met veel lijden, maar die zelf niet meer in staat zijn om hun mening te uiten (bijvoorbeeld door vergevorderde dementie, of gedaald bewustzijn). Bij levensbeëindiging in deze context spreekt men ook wel van levensbeëindiging uit medelijden. In veel gevallen is er over deze beslissing wel nog met de patiënt gesproken voor die in het aftakelingsproces terechtkwam. Dikwijls ook wordt deze beslissing genomen in nauw overleg met de betrokken familieleden van de patiënt. In principe is deze praktijk strafbaar, maar zelden worden deze gevallen vervolgd gezien de uitzichtloze toestand van de patiënt en de voorafgaande besprekingen met patiënt en familie, maar soms ook door gebrek aan harde bewijzen. Deze praktijk komt momenteel voor in $0,4 \%$ van de sterfgevallen in Nederland en in 1,8\% van de sterfgevallen in Vlaanderen. ${ }^{3,4}$ 


\subsubsection{Rol van verpleegkundigen bij beslissingen aan het levenseinde}

Zeker in de intramurale zorg, maar dikwijls ook in de thuiszorg zien verpleegkundigen de patiënt dagelijks, op verschillende tijdstippen en in verschillende situaties. Het contact van de verpleegkundige met de patiënt is meestal meer vertrouwelijk en minder formeel dan het contact tussen de patiënt en de behandelende arts. Verpleegkundigen zijn vaak ook directe getuigen van de interacties tussen de patiënt en diens familieleden en naasten. Bij uitstek zijn ze ook degenen die de continuïteit van zorg verzekeren, en als verbindingspersoon fungeren tussen de patiënt en de andere betrokken zorgverleners. Dit alles maakt dat verpleegkundigen meer dan andere zorgverleners een totaalbeeld van de patiënt krijgen, waarin zowel lichamelijke, psychologische, sociale als spirituele aspecten een plaats krijgen. Deze sleutelpositie van verpleegkundigen leidt ertoe dat zij unieke informatie kunnen aanbrengen, die onmisbaar is om de juiste beslissingen aan het levenseinde te nemen, bijvoorbeeld over de ware aard van de wens van de patiënt, de eventuele druk van familie, over zijn veranderende lichamelijke toestand, over mogelijke sociale ondersteuning, over zinvragen waarmee de patiënt worstelt, enzovoort. Maar ook bij de communicatie tussen de patiënt, zijn naasten en het behandelteam hebben verpleegkundigen een duidelijke taak. Denk maar aan het navragen bij de patiënt en familie of de informatie van de arts juist begrepen is, het vertalen van medisch jargon in begrijpelijke taal, het antwoorden op bijkomende vragen, enzovoort. Verpleegkundigen dienen zich bewust te zijn van het belang van hun bijdrage in deze beslissingen. Helaas wordt deze unieke positie van verpleegkundigen niet altijd als dusdanig door de verantwoordelijke arts begrepen. ${ }^{8}$

Anderzijds worden van oudsher verschillende handelingen door de behandelende arts aan verpleegkundigen gedelegeerd, zoals het toedienen van medicatie, het aanbrengen van een intraveneus infuus, het al dan niet opstarten van sondevoeding, en dergelijke. Ook bij medische beslissingen aan het levenseinde is dit niet anders. In bepaalde gevallen worden verpleegkundigen ook rechtstreeks betrokken bij het assisteren van de arts bij een handeling rond het levenseinde, zoals bij het (niet) reanimeren van een patiënt of het (niet) stopzetten van een beademing. Voor zover deze handelingen plaatsvinden binnen het normaal medisch handelen, zullen ze onder de verantwoordelijkheid van de arts uitgevoerd worden en over het algemeen weinig problemen geven. Maar wanneer het een beslissing betreft die daar in principe buiten valt, zoals het toedienen van levensbeëindigende middelen, kan een verpleegkundige hoofdelijk aansprakelijk gesteld worden, ongeacht de verantwoordelijkheid en eventuele opdracht van de arts. Het is belangrijk dat verpleegkundigen beseffen dat er (wettelijke en morele) grenzen zijn aan wat zij zelf mogen doen. Zij zijn niet verplicht alle opdrachten die de arts hen geeft uit te voeren. In Nederland zijn door de betrokken beroepsgroepen richtlijnen uitgewerkt die de taakverdeling rond deze 
delicate beslissingen tussen artsen en verpleegkundigen regelen. Met betrekking tot euthanasie worden daar voor de verpleegkundigen bijvoorbeeld de volgende vuistregels gehanteerd. 9

II Het nemen van de beslissing om in te gaan op de euthanasievraag van de patiënt, het meedelen van het concrete verloop/planning aan de patiënt (en familie), en het uitvoeren van euthanasie is de taak van de arts. Beperk je hulp tot informeren, adviseren en ondersteunen.

II Je hebt altijd recht om te weigeren mee te werken aan euthanasie. Probeer dit wel goed op voorhand kenbaar te maken zodat de zorg overgenomen kan worden door een collega, met respect voor de wens van de patiënt.

II Beperk je hulp bij het uitvoeren van de euthanasie heel strikt tot voorbereidingshandelingen. Verricht alleen handelingen waarop minstens nog één handeling van de arts moet volgen om het leven van de patiënt te beëindigen.

II Pas op met spontaan bijspringen tijdens het uitvoeren. Wees eerder terughoudend.

III Trek aan de bel als je twijfelt of zeker weet dat niet alle verplichte zorgvuldigheidsvereisten bij euthanasie werden nageleefd. Bespreek dit eerst met de betrokken arts en met collega's. Schakel desnoods leidinggevenden in, of rapporteer het aan de ethische commissie van je instelling.

w Maak een gedetailleerd schriftelijk verslag in het verpleegdossier over de afspraken met betrekking tot je taken bij het uitvoeren.

- Wacht na de euthanasie met het opbaren van de patiënt totdat alles aan de bevoegde instanties gemeld is. Bewaak dat het melden ook daadwerkelijk gebeurt.

- Besteed voldoende aandacht aan de opvang van de nabestaanden en medepatiënten. Geef voldoende informatie en ruimte om te praten, maar verwijs ook tijdig naar andere professionals.

w Heb ook oog voor opvang van collega's en vooral ook voor je eigen behoefte aan ondersteuning.

\subsubsection{Conclusie}

Aan het levenseinde plaatst de zorg voor ongeneeslijk zieke patiënten zorgverleners vaak voor moeilijke en ingrijpende beslissingen. Deze beslissingen zijn gericht op het bieden van de best mogelijke levenskwaliteit voor de patiënt en zijn naasten. Ze zijn erg gevarieerd en betreffen het al dan niet (verder) behandelen, pijn- en symptoombestrijding, en soms het aanwenden van levensbeëindigende middelen. Deze beslissingen moeten zo zorgvuldig mogelijk worden genomen, in samenspraak met de patiënt en zijn naasten en in overleg met de betrokken zorgverleners. De verpleegkundigen spelen een cruciale rol in dit overleg en zijn ook vaak betrokken bij de uitvoering van de beslissing. Het is belangrijk dat verpleegkundigen deze taak goed voorbereid uitvoeren, maar ook de eigen grenzen onder ogen zien (zie ook paragraaf 3.1). 


\section{LITERATUUR}

1 Legemaate, J. Medisch handelen rond het levenseinde. Bohn Stafleu van Loghum, Houten, 2006.

2 Broeckaert, B. Medisch begeleid sterven: Begrippenkader. Federatie Palliatieve Zorg Vlaanderen vzw, Wemmel, 2006.

3 Bilsen, J., J. Cohen, K. Chambaere, et al. Medical end-of-life practices under the euthanasia law in Belgium. New England Joumal of Medicine, 2009, 361, 1119-1121.

4 Heide, A. van der, B. Onwuteaka-Philipsen, M.L. Rurup, et al. End-of-life practices in the Netherlands under the Euthanasia Act. New England Journal of Medicine, 2007, 356, 1957-1965.

5 KNMG-richtijn palliatieve sedatie. Koninklijke Nederlandse Maatschappij tot bevordering der Geneeskunde, Utrecht, 2009.

6 Van de Keerse, H. Richtlijn palliatieve sedatie wil informeren en houvast bieden. Artsenkrant, 2011, $2130,6$.

7 Deliens, L. \& G. van der Wal. Overeenkomsten en verschillen tussen de euthanasiewetten van België en Nederland. Nederlands Tijdschrift voor Geneeskunde, 2003, 147, 169-174.

8 Inghelbrecht, E., J. Bilsen, F. Mortier \& L. Deliens. Nurses' attitudes towards end-of-life decisions in medical practice: a nationwide study in Flanders, Belgium. Palliative Medicine, 2009, 23, $649-658$.

9 Vossen, C. Hoe handel je zorguldig bij euthanasie. Handreiking voor een goede samenwerking tussen arts, verpleegkundige en verzorgende. V\&VN, Utrecht, 200\%. www.venvn.nl. 


\subsection{LEREN IN DE PALLIATIEVE ZORG}

\section{Paul Destrooper}

Een opleiding of (bij)scholing in palliatieve zorg heeft haar eigenheden. Het holistisch concept in de palliatieve zorg geeft een grote herkenbaarheid voor de cursisten. Iedereen weet wel iets over spirituele, sociale, psychische en fysieke verschijnselen. Cursisten die kiezen voor een opleiding of scholing in de palliatieve zorg, zijn vaak al gevormde personen met een basisopleiding en (deel)deskundigheid. Het belangrijkste studiemateriaal dat behandeld wordt, zijn de ervaringen van de cursisten zelf. Ze hebben deze vaak opgebouwd door patiëntcontacten of door collega's aan het werk te zien. Soms zijn ze verontwaardigd over hoe wordt omgegaan met patiënten in de laatste levensfase. Soms zijn het juist de voorbeelden van hoe omgegaan kan worden in de laatste levensfase die de aanleiding zijn om zelf een opleiding of (bij-) scholing te volgen. De opleiders zullen de opgebouwde basisdeskundigheid moeten waarderen maar deze ook verbreden. De leermethoden kunnen het best aansluiten bij de werkwijzen in het werkveld. Een groepsgesprek in de opleiding kan als voorbeeld dienen voor een teamgesprek op de werkvloer. Het inbrengen van de eigen praktijkervaringen, en er samen over reflecteren, is leerzaam, zowel in de opleiding en scholing als op de werkvloer.

\subsubsection{De ontmoeting van het spontaan leren en het reflexief leren}

In het omgaan met (dood)zieke patiënten wordt veel geleerd over eindigheid, het afronden van het leven, het denken over na dit leven, over de pijn van het leven. De zorgverlener wordt kundig door het ervaren van wijsheid, twijfels en lijden van die patiënten. Het is goed dit leerproces door te maken, zonder zich af te vragen of dit klopt met theorieën over ziek-zijn en sterven. Dit is wat bedoeld wordt met het spontane leren. Het leren komt op de zorgverlener af door de uitoefening van zijn beroep. Er wordt geleerd door het proces mee te maken van een individuele patiënt. Dit is uiteraard niet te veralgemeniseren voor alle patiënten met wie de zorgverlener in eenzelfde situatie op de werkvloer in contact komt.

Literatuur en opleiders helpen om ondanks de veelheid van patiënten, sleutels te vinden die bij elk van de patiënten te hanteren zijn. Er vormen zich 'richtlijnen' in het hoofd, in het handelen. Deze worden getoetst aan de praktijk van verschillende zorgverleners en aan relevant onderzoek over zorg. Hieruit kunnen verschillende houdingen naar voren komen. Zo is er de reflecterende, goed opgeleide zorgverlener die elke patiënt benadert vanuit aangeleerde kennis en vaardigheden, en met een grote zorgvuldigheid het geleerde in praktijk brengt. Er is de houding van de spontane zorgverlener die zonder verder na te denken reageert op en meegaat met de patiënt. Maar er is ook een derde attitude, namelijk de zorgverlener die zich niet distantieert van de individuele patiënt, maar daarover wel reflecteert. 
Opleiders moeten oog hebben voor de spontane ervaring en dit leren verbinden met wat de wetenschap ons aanbrengt, zonder een van beide uit het oog te verliezen. Leren óver palliatieve zorg zonder samenhang met ervaring is evenzeer een valstrik als uitsluitend leren vanuit gevoel en omgang met de individuele patiënt. Dit is een pleidooi om open te staan voor het concrete verhaal van de zorgverlener én dit te verbinden met bestaande kennis.

\subsubsection{Leren van ervaring en ervaringsleren}

Het onderscheid tussen leren van ervaring en ervaringsleren kan verhelderend zijn. In de zorg gebeurt veel. Deze ervaringen stemmen tot nadenken. Hoe komt het dat de patiënt op een bepaalde manier reageert? Hoe komt het dat deze houding choqueert? De verzorging van de ene patiënt leert hoe het eventueel ook zou kunnen bij een andere patiënt. De wijze waarop een patiënt het zorgend handelen evalueert, verschaft kennis over dit handelen. Is deze werkwijze herhaalbaar of juist niet? Ervaring is nodig om te leren. Daarnaast kan kennis ook getoetst worden aan nieuwe ervaringen. Dit kan door bepaalde doelen te stellen voor een leerstage. Een voorbeeld: het is bekend dat mondhygiëne voor het comfort van een patiënt in de palliatieve fase heel belangrijk is. Hoe kan dit verder uitgewerkt worden om te komen tot een betere praktijk? In een leerstage op bijvoorbeeld een palliatieve eenheid kan de stagiair een werkstuk maken over het omgaan met mondhygiëne. Een gesprek met bijvoorbeeld een tandarts kan de stagiair verder helpen. Hier worden kennis en kunde getoetst aan de praktijk. Het is doelgericht leren en dit kan helpen om een stage of training in de palliatieve zorg succesvoller te maken. Een goed stageverslag kan dan een aanzet zijn om de praktijk verder te onderzoeken.

\subsubsection{Leren van anderen: patiënten, collega's, deelnemers aan een groepsproces en opleiders}

Er zijn veel personen die een leerproces ondersteunen, beïnvloeden en vormen.

II De patiënt met zijn vragen en zijn manier van omgaan met het ziek-zijn, brengt de zorgverlener tot reflectie over een bepaalde werkwijze. Het is goed om lang en systematisch stil te staan bij de vraag: Wat leert de patiënt aan de zorgverlener? In een palliatieve zorgsetting, waar de hoogtechnologische zorg plaatsmaakt voor comfortzorg, is de patiënt de meest aangewezen persoon om deze zorg te evalueren op grond van de levenskwaliteit.

- Het gesprek binnen een team, de vragen over het handelen van elk teamlid, vernieuwt en verruimt elkaars werkwijze. Blijven wij deze kritische reflectie opbrengen en gaan we met elkaar over het beroep in gesprek? Dit is niet vanzelfsprekend, zeker als er geen veiligheid is of indien elkaars werkwijze niet serieus wordt genomen. Collega's kunnen een bijdrage leveren aan het leerproces, maar collega's kunnen het leerproces ook negatief beïnvloeden, zeker als de geboden palliatieve zorg als een evidentie wordt beschouwd. 
w De mate van ervaring en deskundigheid van de deelnemers aan het groepsproces is belangrijk om de juiste vragen te stellen. De deskundigheid die in een opleiding/training wordt verworven om een goed groepsproces te creëren, zal op haar beurt op de werkvloer van nut zijn in de teamcommunicatie.

" Opleiders kunnen het denken en handelen van cursisten in een context brengen. Soms krijgt de lerende persoon door de vragen van de opleider de indruk dat meer in hem aanwezig is dan hij vermoedde. Dit was de kracht van de oude wijsgeer Socrates: hij liet de ander de wijsheid in zichzelf ontdekken. Door een aanwijzing, door een bevestiging, door een sleutel, door een model kan veel van de verborgen deskundigheid naar boven komen.

\subsubsection{Model-leren en ontwikkelen van modellen}

In de loop van de laatste decennia zijn verschillende modellen ontwikkeld over bijvoorbeeld stervensbegeleiding. Een voorbeeld daarvan is het model van Kübler-Ross. ${ }^{1}$ Een model kan men zien als een aangepaste weergave van de realiteit. Met fotoshopping kan bijvoorbeeld veel en zo is het papier eveneens geduldig om het stervensproces te beschrijven, maar de realiteit is vaak anders. Zijn modellen daarom waardeloos? Nee, zoals Plato de wijsgeer aangeeft kan een model een schaduw zijn van de werkelijkheid. Een schaduw die door een juiste belichting de realiteit verheldert. Het slaafs navolgen van een model kan echter leiden tot frustraties. Een model kan dus zijn plaats krijgen als een voorbeeld dat niet samenvalt met de realiteit maar deze wel inzichtelijk maakt. Het is goed om modellen relativerend te bespreken en ook om te kijken of het zelf ontwikkelen van 'modellen' kan helpen. Is er bijvoorbeeld in het stervensproces van patiënten waar je als zorgverlener mee te maken hebt een systematiek te zien, waaruit een mogelijke procedure kan worden ontwikkeld die dan kan helpen bij een volgend stervensproces? Het gaat daarbij om een zelf ontwikkeld model gebaseerd op ervaring.

\subsubsection{Het leerproces als groepsgebeuren en als individueel gebeuren}

Zorgverleners weten wat zorg is: ze hebben zorg gekregen, zorg gegeven. Een groepsproces stimuleert het denken over zorg. In het kader van palliatieve zorg zijn er zorgverleners uit allerlei disciplines en met vele achtergronden. Het samen spreken stimuleert het persoonlijke proces. Het is niet de bedoeling dat de groep altijd tot consensus komt. Dan krijgen we de grootste gemene deler of het kleinste gemene veelvoud en beide gaan voorbij aan het individuele leerproces, ze dreigen het zelfs op te schorten. Er kan geen dictatuur van de groep zijn, noch een individu dat zich verschuilt achter een 'men zegt' of 'de groep beslist'. Een zorgverlener moet zelf de lastige weg blijven gaan om datgene te verwerken wat gehoord en gezien wordt. Het bijhouden van een dagboek waarin een zorgverlener het leren verwoordt, kan een hulpmiddel zijn om het individuele leren bij te houden en het niet te verwarren met het groepsgebeuren. 


\subsubsection{Interactief leren}

Interactief leren kan voorgesteld worden als een roos met blaadjes die allemaal om een kern zitten. Tussen de verschillende blaadjes onderling en met de kern is er een voortdurende interactie. Dit geeft een spanning die het geheel samenhoudt. Als dat niet het geval is, kom je al vlug tot een roos waarvan de blaadjes afvallen of tot een kern die niet gevoed wordt door de blaadjes en afsterft. In de palliatieve zorg hanteren we een interactief model, de patiënt wordt betrokken bij de zorg. Hij is als goed geïnformeerde patiënt de aangever van de zorgvraag. Opleidingen en scholingen in de palliatieve zorg zullen ook gebaseerd zijn op een interactief model, en moeten aansluiten bij de attitude die ze willen aanleren.

\subsubsection{Leerwegen}

Het leren van ervaring komt in stages veel aan bod. Er is zowel begeleiding van het opleidende instituut als van de ontvangende zorgvoorziening. Hoe beter de afspraken zijn en hoe duidelijker het doel, des te meer kans dat deze tijd een leertijd is. We zien een stage vaak het best verlopen in een nieuwe werkomgeving, hoewel het ook kan op het eigen werkterrein. Het vraagt dan wel een grote zorgvuldigheid om de beoogde doelen te kunnen realiseren.

Cursisten kunnen ook leren van casussen, al dan niet vanuit de eigen praktijkervaring ingebracht. In die gevallen wordt veelal met anderen over de voorliggende casus gediscussieerd. Met hoe meer personen eraan gewerkt wordt, des te meer wegen er worden aangereikt om met een casus om te gaan. Cursisten zien dan dat er niet één weg is, maar dat elke aanpak bepaalde effecten heeft. Deze effecten kunnen inschatten is waardevol om goed te beseffen wat je doet, waarom je het doet en of dit het beoogde effect is.

In de meeste opleidingen zijn er vormen van hoorcolleges: de kennis van de opleider wordt op die manier doorgegeven. Dit gebeurt eveneens door literatuurstudie. Een goede aanvulling hierop zijn observaties en oefeningen in de praktijk. Hierin wordt door de cursist zowel kennis verworven door de opleider aan het werk te zien als door dit zelf om te zetten in de eigen praktijk.

Elke vorm van leren heeft zijn eigen dynamiek. Om het leren succesvol te maken, kunnen het best een aantal vormen van leren naast elkaar worden aangeboden.

\subsubsection{Conclusie}

Het leren in palliatieve zorg heeft een eigen invulling en kan samengevat worden in drie leerwijzen: via samenspraak, interactief en reflexief. Deze drie staan niet in een vooraf bepaalde volgorde, maar zijn wel noodzakelijk voor een volledig leerproces. Evaluaties van cursisten ondersteunen deze conclusie en nodigen lesgevers uit de sterke band tussen het werkgebied, onderzoek en ontwikkeling van een palliatieve praktijk te handhaven. 


\section{LITERATUUR}

1 Kübler-Ross, E. Lessen voor levenden: gesprekken met stervenden. Bilthoven: Ambo, 1969 . De tekst is verder beinvloed door de praktijk en door onderstaande recente literatuur.

Cantillon, P. ABC of learning and teaching in medicine: Teaching large groups. British Medical Journal, $2003,326,437-440$.

De Vlieger, M., N. Gorchs, P. Larkin \& F. Porchet. A guide for the development of palliative nurse education in Europe. Palliative Medicine, 2004, 18, 401-403.

Glanz, K., B. Rimer \& K. Viswanat, Health Behavior and Health Education: Theory, research, and practice. Jossey-Bass, San Francisco, 2008.

Meier, D., S. Isaacs \& R. Hughes. Palliative Care: Transforming the care of serious illness. Jossey-Bass, San Francisco, 2010.

Pike, R. Creative Training Techniques Handbook. HRD Press, Minneapolis MI, 2003.

Silberman, M. The Handbook of Experiential Learning. Pfeiffer, San Francisco, 2007. 


\title{
2 Organisatie en aanbod van de palliatieve zorg
}

\author{
2.1 Netwerken in de palliatieve zorg 44 \\ 2.2 Intramurale palliatieve zorg 50 \\ 2.3 Palliatieve zorg thuis 54 \\ 2.4 Dagcentra en dagbehandeling 61 \\ 2.5 Zelfstandige hospicevoorzieningen 65
}




\section{1 NETWERKEN IN DE PALLIATIEVE ZORG}

\section{Frie Hermans, Monique Vahedi Nikbakht en Adriaan Visser}

Zowel in Nederland als in Vlaanderen hebben regionale netwerken van samenwerkende partijen op het terrein van palliatieve zorg een grote vlucht genomen. In de coördinatie van de palliatieve zorg spelen de netwerken een belangrijke rol. Ook leveren de netwerken een bijdrage aan het optimaliseren van de mogelijkheid om op de plaats van voorkeur (meestal thuis) te sterven. Omdat qua organisatie de netwerken in Nederland en Vlaanderen redelijk verschillend zijn, bespreken we in afzonderlijke paragrafen de Nederlandse en Vlaamse netwerken.

\subsubsection{Netwerken palliatieve zorg in Nederland}

\section{Omschrijving en financiering netwerken palliatieve zorg in Nederland}

Vanaf medio jaren negentig wordt door het ministerie van Volksgezondheid, Welzijn en Sport (VWS) de ontwikkeling van de palliatieve zorg fors gestimuleerd. ${ }^{1}$ Palliatieve zorg dient volgens VWS een onderdeel te zijn van de reguliere zorg, waarbij generalistische hulpverleners voor advisering terechtkunnen bij specialistische consultatieteams (zie paragraaf 2.3). In de randvoorwaardelijke sfeer verwacht de overheid dat palliatieve hulpverleners samenwerken in organisatorische netwerken, waarbij regionaal ondersteuning wordt geboden door integrale kankercentra (IKC's). ${ }^{2}$ Anno zon heeft het stimuleringsbeleid geresulteerd in een landelijk dekkend geheel van 71 netwerkregio's met veelal één of meer consultatieteams en maakt palliatieve zorg inderdaad deel uit van de reguliere gezondheidszorg. ${ }^{3}$ In principe is palliatieve zorg daarmee beschikbaar voor iedereen die in Nederland verblijft.

Een netwerk palliatieve zorg wordt gedefinieerd als 'een duurzame transmurale samenwerking op lokaal niveau, waarbij gestreefd wordt naar een integrale, samenhangende en structureel ingebedde palliatieve zorg in de regio'. ${ }^{4}$ Het is met andere woorden een samenwerkingsverband van partijen die zich bezighouden met palliatieve zorg in een bepaalde regio. De kern van een netwerk wordt bijna altijd gevormd door zorgvoorzieningen zoals ziekenhuizen, verpleeg- en verzorgingshuizen, thuiszorgorganisaties, hospices/bijna-thuis-huizen en vrijwilligersorganisaties. Per netwerk verschilt het type en vooral het aantal deelnemende organisaties, wat samenhangt met de grootte van het gebied. Dit is tevens bepalend voor de organisatorische structuur van een netwerk. De grotere netwerken kennen soms een gelaagdheid in niveaus, zoals een strategische beleidsgroep (toezichthoudend), een stuurgroep (beleidsbepalend) en 'daaronder' werkgroepen (uitvoerend). Ook zijn er netwerken die zich geografisch opsplitsen in ketens, om als netwerk optimaal te kunnen functioneren. ${ }^{5}$ 
De netwerken kennen ieder een netwerkcoördinator die ondersteuning biedt aan de organisatorische en zorginhoudelijke processen binnen het netwerk. ${ }^{5}$ De landelijke organisatie Agora organiseert in samenwerking met de integrale kankercentra de ondersteuning van de netwerkcoördinatoren. Hiertoe is de Werkgroep Ondersteuning Netwerken geformeerd, waarbinnen netwerkcoördinatoren onderling kennis en ervaring uitwisselen en worden geïnformeerd over specifieke thema's. ${ }^{6}$

De financiering van palliatieve zorg in Nederland is een mix van financiën uit de Algemene Wet Bijzondere Ziektekosten, de Zorgverzekeringswet en de Wet maatschappelijke ondersteuning. Voor de netwerken palliatieve zorg betekent dit financiële schotten die integrale transmurale samenwerking in de weg kunnen staan. In het Plan van Aanpak Palliatieve Zorg 2008-2010 is één van de thema's het verbeteren van de organisatie en financiering van de palliatieve zorg. ${ }^{7}$ Overigens kunnen netwerken palliatieve zorg voor zichzelf ook financiering aanvragen volgens de subsidieregeling Instellingssubsidies Netwerken Palliatieve Zorg van het ministerie van VWS. ${ }^{8}$ Vanuit die subsidieregeling wordt de hoogte van de financiering vastgesteld aan de hand van onder meer het aantal inwoners in het adherentiegebied van het netwerk. De subsidie blijkt in de praktijk veelal ontoereikend, waardoor ambitieuze plannen niet altijd kunnen worden gerealiseerd. De netwerken worden echter wel getoetst op behaalde resultaten. ${ }^{7}$

\section{Doelen en uitkomsten van de netwerken palliatieve zorg in Nederland}

$\mathrm{Bij}$ het ontstaan van een netwerk zijn bekendheid en draagvlak van groot belang. Eén of twee enthousiaste initiatiefnemers, het gezamenlijk opstellen van een startdocument, bij voorkeur op basis van onderzoek vanuit verschillend perspectief, dragen volgens onderzoek positief bij aan een goede start van een netwerk palliatieve zorg. ${ }^{5}$

De doelstellingen van de netwerken palliatieve zorg zijn hoofdzakelijk gericht op het verbeteren van de afstemming en de onderlinge samenwerking, een verbeterde toegankelijkheid van de zorg en een betere kwaliteit van de deelnemende organisaties en hun zorgaanbod. ${ }^{5}$ Het werken aan de onderlinge samenwerking tussen de verschillende organisaties is voor netwerken belangrijk. Zij willen hiermee een gevarieerd aanbod van palliatieve zorgvoorzieningen creëren. Het onderling afstemmen van dit gecreëerde palliatieve zorgaanbod houdt hiermee nauw verband. ${ }^{9}$

Een andere kernfunctie van een netwerk palliatieve zorg is het beschikbaar stellen van kennis aan zorgverleners. Voor het overgrote deel van de netwerken betreft het hier een deskundigheidsprogramma, dat zich concreet uit in een activiteitenprogramma binnen de regio. Zo worden er bijvoorbeeld casuiistiekbesprekingen en intervisiebijeenkomsten gehouden en wordt informatie- en documentatiemateriaal ontwikkeld. Ook moet bij deskundigheidsbevordering gedacht worden aan de regionale consultatieteams (zie paragraaf 2.3), waar generalistische hulpverleners voor advies terechtkunnen. In enkele netwerken blijft het niet alleen bij deze adviesfunctie, maar wordt de zorg 
ook daadwerkelijk geboden door dit team, bijvoorbeeld door het verlenen van bedsideconsulten. ${ }^{9}$ Om te bewerkstellingen dat de middelen snel op de juiste plek beschikbaar zijn, wordt informatie gegeven, worden samenwerkingsafspraken geëvalueerd en wordt onderzoek gedaan naar knelpunten bij zorgvragers en zorgverleners. ${ }^{9}$

Netwerken palliatieve zorg leiden onder andere tot een toename van persoonlijke contacten en meer onderlinge betrokkenheid en samenwerking. Een andere netwerkuitkomst is dat het zorgaanbod meer inzichtelijk wordt en partijen elkaar beter weten te vinden. Een meer indirecte - en vaak niet als eerste genoemde - uitkomst is een verbeterde patiëntenzorg. Verbetering in de organisatorische aspecten staat veel meer op de voorgrond. ${ }^{\circ}$

In onderzoek worden eveneens verschillende bevorderende en belemmerende factoren voor het functioneren van het netwerk genoemd. Bevorderend zijn gezamenlijke activiteiten op zowel bestuurlijk als operationeel niveau alsook goed overleg op bestuurlijk niveau. Daarnaast zijn financiële ondersteuning van de participerende organisaties en onderlinge goodwill en samenwerking belangrijk. Ook het hebben van een netwerkcoördinator die organisaties kan binden en een voortrekkersrol vervult, is belangrijk. Essentieel is ook het gezamenlijk producten ontwikkelen.

Concurrentie of fusies en onvoldoende financiële ondersteuning leiden echter vaak tot afnemende effectiviteit van het netwerk. Netwerken hebben behoefte aan steun in de vorm van financiering, pr en communicatie. 5.9

\section{Huidige praktijk en de toekomst}

Momenteel (2011) wordt de fase van het pionieren langzaamaan afgesloten. Speerpunt voor de toekomst is (nog steeds) een betere afstemming. Juist ook ten aanzien van ontwikkeling, implementatie, verspreiding en borging van kennis. Veel innovaties worden in de vorm van projecten door de netwerken opgezet en/of geïmplementeerd. Denk aan projectactiviteiten als het opstellen van een sociale kaart, ontwikkelen van folders en scholingsprogramma's. Onder de meer omvangrijke projecten valt bijvoorbeeld de implementatie van de Liverpool Care Pathway ofwel het zorgpad voor de stervensfase, waarvoor nu een landelijke implementatie loopt. Maar ook de invoering van continuïteitshuisbezoeken door thuiszorgorganisaties of de implementatie van de Landelijke Eerstelijns Samenwerkingsafspraken (LESA) zijn voorbeelden van ormvangrijke projecten, waarbinnen optimale (transmurale) samenwerking een rol speelt.

Een ander speerpunt voor de toekomst betreft het versterken van de palliatieve zorg in de eerstelijnszorg. De eerste lijn komt namelijk niet alleen in de beginfase, maar ook aan het eind van de palliatief terminale fase veelal nadrukkelijk in beeld. Denk hierbij aan innovatieve vormen van palliatieve dagzorg, palliatieve spreekuren/ poliklinieken. Tot slot wordt vanuit het ministerie van VWS de wens geuit meer nadruk te leggen op het gebruik van kwaliteitsnormen, indicatoren en richtlijnen, waardoor gewerkt kan worden aan een optimale kwaliteit van netwerkzorg, zowel organisatorisch als op professioneel vlak. ${ }^{7}$ 


\subsubsection{Netwerken palliatieve zorg in Vlaanderen}

\section{Wat is een netwerk palliatieve zorg in Vlaanderen?}

De palliatieve zorgbeweging kwam in Vlaanderen in de jaren tachtig op gang. Verspreid over het hele land ontstonden initiatieven voor palliatieve zorgverlening door basiswerkers (artsen en verpleegkundigen) en op vrijwillige basis. In de jaren negentig nam de overheid het initiatief tot de oprichting van palliatieve samenwerkingsverbanden in het gehele land. Een netwerk wordt in Vlaanderen (net als in Nederland) gezien als een samenwerkingsverband tussen hulpverleners en vertegenwoordigers van organisaties die binnen een bepaalde regio met palliatieve zorg bezig zijn. ${ }^{1,12} \mathrm{De}$ Vlaamse Gemeenschap erkent een netwerk palliatieve zorg binnen een regio van minstens 200.000 en hoogstens een miljoen inwoners. Diezelfde netwerken worden door de federale overheid 'samenwerkingsverbanden' genoemd. De subsidies komen gedeeltelijk van de federale overheid en van de Vlaamse Gemeenschap. België telt vijfentwintig netwerken palliatieve zorg waarvan vijftien in Vlaanderen, één tweetalig in Brussel, acht in Wallonië en één in de Duitstalige Gemeenschap.

\section{Taak van de netwerken palliatieve zorg in Vlaanderen}

De netwerken palliatieve zorg vervullen binnen hun regio een belangrijke rol bij de regionale verspreiding van de palliatieve zorgcultuur, zowel in de diverse zorgsettings als onder de bevolking. Dit komt tot uiting in de hen toegewezen opdrachten. De netwerken informeren en sensibiliseren de bredere bevolking over de mogelijkheden van palliatieve zorg. Daardoor worden sterven, dood en rouw opnieuw bespreekbaar. Dit doen ze onder meer door het geven van voordrachten voor ouderenverenigingen. Maar ook door het aanbieden van vormingspakketten, bijvoorbeeld 'Niet te jong voor verlies. Kinderen betrekken bij palliatieve zorg', een pakket dat ook aan scholen wordt aangeboden.

Een andere opdracht van de netwerken is het bevorderen van de deskundigheid van alle betrokken hulpverleners: mantelzorgers, professionele hulpverleners (artsen, verpleegkundigen, paramedici) en vrijwilligers. Dit dient zowel te gebeuren in de thuissituatie als in woon- en zorgcentra en in ziekenhuizen. Naast de gewone overdracht van kennis en vaardigheden is hier ook aandacht voor de 'zorg voor de zorgende'. Zorgverleners moeten verplicht vanuit de overheid jaarlijks een aantal uren vorming volgen. In de praktijk betekent dit dat elk netwerk jaarlijks een vormingsprogramma uitwerkt en organiseert in de vorm van voordrachten, workshops en congressen. Thema's die daarbij aan bod komen, zijn bijvoorbeeld palliatieve zorg en personen met een handicap en spirituele zorg. Netwerken voorzien in een basisopleiding op regionaal niveau terwijl de Federatie Palliatieve Zorg Vlaanderen (FPZV) de meer specialistische vorming voor haar rekening neemt.

Daarnaast staan de netwerken ook in voor het coördineren, ondersteunen en stimuleren van diverse acties om een palliatieve zorgcultuur uit te bouwen. Daarbij is het 
niet de bedoeling in de plaats te treden van bestaande intramurale of extramurale hulpverlening of mantelzorg. De netwerken streven de best mogelijke levenskwaliteit na voor de palliatieve patiënt, in samenwerking en overleg met de patiënt en zijn omgeving en alle betrokken hulpverleners. Het pluralisme van de netwerken moet er ook garant voor staan dat iedere levensvisie gerespecteerd wordt.

De netwerken bieden ook een kader aan waarbinnen vrijwilligers zich kunnen inzetten voor palliatieve patiënten. Vooral de opleiding van vrijwilligerswerk behoort tot de taak van de netwerken. Dit wordt door elk netwerk op een eigen manier ingevuld. Sommige netwerken voorzien alleen in een vormingsaanbod, terwijl andere netwerken daarin een grotere taak op zich nemen zoals het selecteren, het coachen en het evalueren van de vrijwilligers. ${ }^{13.14}$

Binnen iedere netwerkregio is ook een multidisciplinaire begeleidingsequipe voor palliatieve thuiszorg (zie ook paragraaf 2.3) actief. Deze thuiszorgequipes staan in voor de ondersteuning van diegenen die de palliatieve zorgverlening aanbieden (met name de huisarts en de thuisverpleging). Dit betekent dat ze - in overleg met de huisarts ondersteuning en advies geven bij de verzorging van palliatieve patiënten thuis of in een thuisvervangende omgeving. Zo helpen ze bijvoorbeeld bij het zoeken naar comfort bij hinderlijke symptomen (braken, misselijkheid, kortademigheid). In de praktijk zijn er netwerken waar de equipe helemaal geïntegreerd is binnen het netwerk, in andere regio's zijn het netwerk en de equipe twee verschillende juridische structuren.

Ten slotte evalueren de netwerken het palliatiefzorgaanbod in hun regio en onderzoeken ze welke behoeften eventueel nog ingevuld kunnen worden. Hiervoor nemen ze de nodige initiatieven.

\section{Huidige praktijk en knelpunten van netwerken in Vlaanderen}

Iedereen kan de hulp inroepen van het netwerk van zijn/haar regio. Hulpverleners uit diverse zorgsettings, matschappelijke organisaties, patiënten en familieleden kunnen er terecht voor informatie, advies, ondersteuning, voordrachten en opleiding. Ten slotte kunnen ook familieleden een beroep doen op het netwerk, bijvoorbeeld voor ondersteuning bij het rouwproces na het overlijden van de patiënt.

Het voordeel van het netwerksysteem blijft de geografisch dekkende structuur die ook in de praktijk blijkt te werken. Knelpunt is echter - net als in Nederland - de gebrekkige financiering:15 de netwerken moeten voor hun erkenning beschikken over een coördinator en een psycholoog, maar de financiering brengt bijvoorbeeld niet de anciënniteit in rekening. Daarnaast zijn er ook bijna geen middelen om de werking van de netwerken te financieren. Dit betekent dat een deel van de tijd voorzien voor kernopdrachten, gaat naar het zoeken van extra fondsen, bijvoorbeeld voor het doorvoeren van automatisering. De laatste jaren ontstond op dit vlak een tendens om op provinciaal niveau samen te werken en de taken te verdelen. 


\subsubsection{Conclusie}

De netwerken palliatieve zorg hebben in de afgelopen vijftien jaar een belangrijke evolutie doorgemaakt, zowel in Vlaanderen als in Nederland. Ze hebben hun rol opgenomen in de verspreiding van informatie over palliatieve zorg in verschillende zorgsettings. Ook hebben ze belangrijke bijdragen geleverd aan regionale samenwerking en afstemming in de palliatieve zorg, en aan deskundigheidsbevordering, consultatie- en ondersteuningsmogelijkheden voor zorgverleners. Steeds met als doel voor ogen dat mensen verzorgd kunnen worden en uiteindelijk sterven waar ze dat wensen en op de manier die ze wensen.

\section{LITERATUUR}

1 Palliatieve zorg in de terminale fase. Brief aan de voorzitter van de Tweede Kamer der StatenGeneraal. Ministerie van VWS, Den Haag, 18 april 1996.

2 Mistiaen, P., L. van Ruth \& A.L. Francke. Monitor palliatieve zorg; Rapport 2006 en bevindingen over drie jaar monitor. NIVEL, Utrecht, 2006.

3 Netwerk Palliatieve Zorg. www.netwerkpalliatievezorg.nl/Denetwerken/tabid/54/Default.aspx. Geraadpleegd op 20 januari 2010.

4 Programma 1998-2002. Centrum voor de Ontwikkeling van Palliatieve Zorg, Rotterdam, 1998.

5 Vahedi Nikbakht-van de Sande, C.V.M., C.C.D. van der Rijt, A.Ph. Visser, et al. Lokale netwerken palliatieve zorg: Visie van netwerkleden. Tijdschrift voor Gezondheidswetenschappen, 2004, 82, 162-168.

6 Agora. www.palliatief.nl/ZorgKiezen/Netwerkenpalliatievezorg/tabid/2211/Default.aspx. Geraadpleegd op 20 januari 2010.

7 Plan van Aanpak Palliatieve Zorg 2008-2010. Ministerie van VWS, Den Haag, 2008.

8 Ministerie van Volksgezondheid, Welzijn en Sport. http://wetten.overheid.nl/BWBRoo22841/ geldigheidsdatum_20-01-2010\#Bijlage1, 20 januari 2010.

9 Baecke, J.A.H. \& G. Cazemier. Monitor CVTM-regeling: netwerken palliatieve zorg; resultaten meting 2006. BMC, Leusden, 2007.

10 Visser, A.Ph., C.V.D. Vahedi Nikbakht, C.C.D. van der Rijt \& J.F.A. Pruyn. Netwerken in de palliatieve zorg. In: Handboek Zorgvernieuwing, deel B9, 2005.

11 Besluit Vlaamse Regering 3 mei 1995 houdende erkenning en subsidiëring van netwerken palliatieve zorg. Ministerie van Welzijn, Brussel, 1995.

12 Koninklijk Besluit 19 juni 1997 houdende vaststelling van de normen waaraan een samenwerkingsverband inzake palliatieve zorg moet voldoen om te worden erkend. Ministerie van Welzijn, Brussel, 1995.

13 Decreet Vlaamse Regering 23 maart 1994 betreffende het georganiseerd vrijwilligerswerk in de welzijns- en gezondheidssector.

14 Baerten, H., B. Clicteur, P. Helaers, et al. De onzichtbare kracht - vrijwilligers in de palliatieve thuiszorg. Presentatie ge EAPC-congres, Aken, 2005. www.palliatief.be.

15 Evaluatierapport palliatieve zorg. Federale Evaluatiecel Palliatieve Zorg, Brussel, 2008. 


\subsection{INTRAMURALE PALLIATIEVE ZORG}

\section{Inge Bossupt, Karen Van Beek en Anneke Francke}

De meeste gezonde mensen wensen op het einde van hun leven thuis verzorgd te worden en indien mogelijk ook thuis te sterven. ${ }^{1}$ Toch sterft lang niet iedereen in de eigen woning: van alle gevallen van overlijden in Vlaanderen vindt ruim de helft $(53,7 \%)$ plaats in een ziekenhuis en ongeveer een vijfde $(19,8 \%)$ in de residentiële ouderenzorg. ${ }^{2}$ In de studie die voorgaande percentages presenteerde, werd geen onderscheid gemaakt tussen de groep die overleed aan een acute aandoening en de groep die stierf ten gevolge van chronische aandoeningen die relevant zijn voor palliatieve zorg, zoals kanker, COPD, hartfalen of dementie. In een Nederlandse studie is dat onderscheid wel gemaakt en daaruit bleek dat van de Nederlanders die overlijden aan kanker of andere chronische aandoeningen, ruim een kwart (27\%) in een ziekenhuis overlijdt, $25 \%$ in een verpleeghuis en $10 \%$ in een verzorgingshuis. ${ }^{3}$

In de volgende paragraaf beschrijven we de verschillende intramurale zorgmogelijkheden in Vlaanderen, waarna in paragraaf 2.2.2 de organisatie van de Nederlandse palliatieve zorg wordt besproken.

\subsubsection{Intramurale palliatieve zorg in Vlaanderen}

\section{Palliatieve zorgeenheden verbonden aan ziekenhuizen in Vlaanderen}

Bij patiënten met een ongeneeslijke ziekte en een korte levensverwachting en bij wie thuisverzorging niet meer haalbaar is, kan een opname op een palliatieve zorgeenheid overwogen worden. Vaak is dit een opname tot het overlijden van een patiënt, maar dit kan ook een tijdelijke opname zijn om medicatie aan te passen, om tijd te nemen om thuiszorg voor te bereiden of om de familie enige tijd te ontlasten.

De palliatieve zorgeenheid is een afzonderlijke, kleine huiselijke eenheid van minimaal zes tot maximaal twaalf bedden, meestal gesitueerd binnen het ziekenhuis. België telt $5^{1}$ palliatieve zorgeenheden, waarvan 29 in Vlaanderen en vijf in Brussel.

Medewerkers uit verschillende disciplines (verpleegkundige, arts, psycholoog, sociaal werker, kinesitherapeut, diëtist, pastor en vrijwilligers) maken het mogelijk om individuele totaalzorg aan te bieden. Pijn en andere symptomen worden onder controle gehouden en psychologische begeleiding, rouwvoorbereiding en -begeleiding worden aan de patiënt, en aan zijn familie en naasten aangeboden. $\mathrm{Er}$ is ruimte om zo volwaardig mogelijk te leven in relatie met de geliefden en om diepere levensvragen te bespreken. Bezoek is doorlopend mogelijk en familie kan zo nodig blijven overnachten. Indien gewenst worden ze bij de verzorging betrokken.

Vanuit het ziekenhuis wordt een opname op deze zorgeenheid georganiseerd door het palliatief supportteam. Vanuit de thuissituatie gebeurt dit door de huisarts of door de palliatieve thuiszorgequipes (zie paragraaf 2.3) in overleg met de huisarts. 


\section{Palliatief supportteam of palliatieve functie in Vlaamse ziekenhuizen}

Voor ondersteuning van patiënten, opgenomen in het ziekenhuis met een ongeneeslijke aandoening, is de palliatieve functie (meestal palliatief supportteam genoemd) bij wet verplicht in alle ziekenhuizen in België. Het palliatief supportteam (PST) is een mobiel team bestaande uit artsen, verpleegkundigen en psychologen. Voor de overige disciplines werkt het PST samen met de afdeling waar de betrokken patiënt verblijft.

Het palliatief supportteam functioneert in het ziekenhuis en werkt samen met de extramurale zorg. Het PST geeft advies en informatie op uitdrukkelijke vragen van het behandelend team, de familie of de patiënt en probeert samen met hen 'optimale zorg' aan te bieden. Klachten van fysieke, psychische, sociale of spirituele aard worden zo veel mogelijk opgevangen. Noden, zoals graag naar huis willen gaan, overname op de palliatieve zorgeenheid, hulp in de communicatie over (de impact van) het ziek-zijn, worden bespreekbaar gemaakt. Samen wordt actief en creatief naar oplossingen gezocht, rekening houdend met de beleving van patiënt en familie. Het PST neemt de zorg niet over, maar ondersteunt het behandelend team. Bij tijdige inschakeling kan het PST ondersteunen bij belangrijke ethische beslissingen zoals over doorgaan of afbouwen van behandelingen.

Het PST werkt nauw samen met de palliatieve zorgeenheden en de palliatieve thuiszorgequipes (zie paragraaf 2.3), zo kunnen patiënten op het einde van hun leven verblijven op de meest gewenste en aangepaste plaats. Naast hun plaats in de patiëntenzorg, werkt het PST aan de structurele integratie van palliatieve zorg binnen het ziekenhuis. Zorgverleners van het PST geven opleidingen over diverse onderwerpen, ze werken beleidslijnen en richtlijnen uit en verrichten wetenschappelijk onderzoek.

\section{Palliatieve zorg in de residentiële Vlaamse ouderenzorg}

De residentiële ouderenzorg in Vlaanderen evolueert naar woon- en zorgcentra (WZC) waarin verschillende opvangvormen voor ouderen (rustoordbedden, rust- en verzorgingstehuisbedden, serviceflats, dagopvang) worden samengebracht. In rustoorden (ROB) wonen zorgbehoevende bejaarden die niet meer in staat zijn om te voorzien in de dagelijkse huishoudelijke taken, vaak door gebrek aan mantelzorgers. Sommige woon- en zorgcentra hebben nast rustoordbedden ook RVT-bedden (rust- en verzorgingstehuisbedden) waar men de zwaar zorgbehoevende bejaarden, dikwijls permanent bedlegerig of totaal dementerend, verzorgt.

Voor de verzorging van terminale patiënten in thuisvervangende ouderenzorg zijn naar analogie met de palliatieve functie in ziekenhuizen, palliatieve functies of palliatieve supportteams (PST) opgericht. Wettelijk geldt dit uitsluitend voor RVT-bedden, toch hebben alle woon- en zorgcentra de opdracht een samenwerkingsovereenkomst te sluiten met het lokale palliatieve netwerk. Het PST bestaat uit de coördinerend en raadgevend arts en de (hoofd)verpleegkundige. Sinds kort is er vrijstelling voor een medewerker die de verantwoordelijkheid draagt voor de uitbouw van de palliatieve zorgcultuur (momenteel o,1 fte voor 30 RVT-bedden). 
Het PST staat in voor de ondersteuning en bijscholing van het personeel (verpleegkundigen, paramedici, kinesitherapeuten en verzorgend personeel) op het vlak van palliatieve zorg. Ze nemen de zorg niet over, maar ondersteunen het behandelend team in het uitvoeren van de comfortzorg.

\subsubsection{Intramurale palliatieve zorg in Nederland}

\section{Palliatieve zorg in Nederlandse ziekenhuizen (inclusief palliatieve units)}

De Nederlandse palliatieve zorg onderscheidt zich qua organisatie enigszins van de Vlaamse situatie. In Nederland is er als het gaat om specifieke palliatieve zorgvoorzieningen een relatief groot aantal zelfstandige hospices en bijna-thuis-huizen (zie paragraaf 2.5), terwijl anno 2011 slechts een beperkt aantal (rond de tien) ziekenhuizen palliatieve afdelingen/units hebben. Deze palliatieve units in ziekenhuizen hebben voornamelijk een functie in de diagnostiek en het instellen van complexe therapie en zijn minder dan bijvoorbeeld de palliatieve units in verpleeg- en verzorgingshuizen (zie hierna) gericht op verblijf.

In Nederland hebben de algemene en academische ziekenhuizen in de eerste plaats een curatieve functie. Dat er desondanks binnen de ziekenhuiswereld expliciete aandacht is voor palliatieve zorg, blijkt bijvoorbeeld ook uit de deelname van ziekenhuizen aan regionale netwerken op het terrein van palliatieve zorg (zie paragraaf 2.1).

Tevens maken ziekenhuisverpleegkundigen en medisch specialisten met expertise op het terrein van zorg vaak deel uit van de regionale consultatieteams (zie paragraaf 2.1). Overigens richten deze consultatieteams zich op alle settings waar palliatieve zorg verleend wordt en zeker niet uitsluitend op de ziekenhuissetting. In die zin onderscheiden ze zich van de palliatieve supportteams genoemd bij het onderdeel over de Vlaamse situatie.

\section{Palliatieve zorg in Nederlandse verpleeghuizen, verzorgingshuizen en palliatieve units}

In Nederland is er in de residentiële ouderenzorg een onderscheid tussen verpleegen verzorgingshuizen. Verpleeghuizen richten zich voornamelijk op ouderen die complexe lichamelijke of psychogeriatrische zorg nodig hebben en die uiteindelijk veelal ook in die instelling zullen overlijden. Palliatieve zorg is van oudsher een belangrijke taak van de verpleeghuisartsen, verzorgenden en verpleegkundigen in de verpleeghuizen. In verpleeghuizen zijn ook altijd paramedici, en meestal ook psychologen en pastoraal medewerkers aanwezig. Dit biedt in principe veel mogelijkheden voor multidisciplinaire palliatieve zorg.

In het algemeen hebben patiënten in verzorgingshuizen minder complexe lichamelijke of psychogeriatrische problemen dan bewoners van verpleeghuizen. Verzorgingshuizen hebben (in tegenstelling tot de verpleeghuizen) vaak ook geen eigen instellingsarts; meestal blijft de eigen huisarts de medische verantwoordelijkheid houden. In verzorgingshuizen zijn vooral verzorgenden en helpenden werkzaam en is er meestal geen paramedische dienst. Sommige verzorgingshuizen hebben echter 
een verpleegafdeling, en ook (verpleegkundig) personeel dat in staat is om wat complexere zorg te verlenen. Het onderscheid tussen enerzijds verzorgingshuizen met verpleegafdeling en anderzijds verpleeghuizen is daarmee soms vaag.

In verpleeg-en verzorgingshuizen wordt ten eerste palliatieve zorg verleend aan de eigen bewoners met een ongeneeslijke, uiteindelijk terminale aandoening. Daarnaast zijn binnen een groot aantal verpleeg- en verzorgingshuizen palliatieve units (in 2010 in totaal rond de 150 ) ingericht voor mensen van buitenaf (zie de website van Agora voor een actueel overzicht van de aantallen palliatieve units in verpleeg-en verzorgingshuizen ${ }^{4}$ ). Gekoppeld aan deze palliatieve units is er een logeermogelijkheid voor naasten. Men probeert een relatief huiselijke omgeving te creëren en de multidisciplinaire zorg wordt op die units vaak ondersteund door vrijwilligers.

De verpleeg-en de verzorgingssector hebben in de afgelopen jaren ook een kwaliteitsverbeterslag proberen te maken door de productie en verspreiding van zorgvuldigheidseisen voor besluitvorming rond het levenseinde en kwaliteitsrichtlijnen voor palliatieve zorg in het verzorgingshuis en in het verpleeghuis. ${ }^{57}$ Daarnaast is het al langer bestaande kwaliteitssysteem high-care hospices uitgebreid naar palliatieve units bij verpleeghuizen. Dit kwaliteitssysteem beschrijft criteria voor de organisatie en het proces van zorg in palliatieve units, bijvoorbeeld rondom intake, (na)zorg en personeelsbeleid. ${ }^{8}$

\subsubsection{Conclusie}

In de ziekenhuizen en residentiële ouderenzorg zijn verschillende initiatieven en mogelijkheden voor goede palliatieve zorg. Daarbij valt onder meer te denken aan de vele palliatieve eenheden verbonden aan ziekenhuizen en de palliatieve supportteams in Vlaanderen. In de Nederlandse situatie zijn bijvoorbeeld de regionale consultatieteams (die zich zowel op ondersteuning van intramurale als extramurale zorgverleners richten) en de palliatieve afdelingen/units in ziekenhuizen, verpleegen verzorgingshuizen, middelen om de kwaliteit van intramurale palliatieve zorg te bevorderen.

\section{LITERATUUR}

I Akker P. van den, K. Luijkx \& S. van Wersch. Waar wilt u doodgaan? Keuzen en overwegingen. IVA, Tilburg, 2005.

2 Cohen J., J. Bilsen, P. Hooft, et al. Dying at home or in an institution using death certificates to explore the factors associated with place of death. Health Policy, 2006, 78, 319-329.

3 Velden L.F.J. van der, A.L. Francke, L. Hingstman \& D.L. Willems. Sterfte aan kanker en andere chronische aandoeningen. Kenmerken in 2006 en trends vanaf 1996. NIVEL, Utrecht, 2007.

4 www.palliatief.nl/ZorgKiezen/Persoortvoorziening/tabid/2210/Default.aspxwww.palliatief.nl. Geraadpleegd op 29 juni 2010.

5 Zorgvuldigheidseisen met betrekking tot de besluitvorming rond het levenseinde. AVVV, NVVA, Sting, Utrecht, 2006.

6 Prismant/Arcares. Kwaliteitsrichtlijnen. Palliatieve terminale zorg in het verzorgingshuis. Arcares, Utrecht, 2002.

7 Prismant/Arcares. Kwaliteitsrichtlijnen. Palliatieve terminale zorg in en vanuit het verpleeghuis. Arcares, Utrecht, 2002.

8 www.perspektkeurmerk.nl/index.php?id=254. Geraadpleegd op 29 juni 2010. 


\subsection{PALliatieve ZORG THuis}

\section{Anneke Francke en Bie Lambrechts}

Ongeveer een kwart van de gevallen van overlijden vindt thuis plaats. Dat is zowel in Nederland als in België het geval., ${ }^{1,2}$ Voor de meeste mensen is 'thuis' ook de voorkeurslocatie om verzorgd te worden tot aan het overlijden. ${ }^{3}$ Palliatieve zorg thuis vraagt echter voldoende beschikbaarheid van mantelzorg en deskundige begeleiding. Over de rol van mantelzorgers en vrijwilligers bij de zorg thuis wordt in hoofdstuk 3 geschreven. In deze paragraaf gaan we vooral in op zorg thuis door professionals. Daaruit zal blijken dat er veel mogelijkheden zijn om ook thuis goede palliatieve zorg te verlenen, waarbij verpleegkundigen, naast huisartsen, vaak een cruciale rol spelen.

\subsubsection{Inhoud en uitgangspunten bij palliatieve zorg thuis}

De huisarts is bij palliatieve zorg thuis verantwoordelijk voor de medische zorg. De zorg van de huisarts bestaat voor een belangrijk deel uit het verlichten van pijn en andere symptomen en psychosociale ondersteuning van de patiënt en zijn belangrijkste naasten. In de vroege palliatieve fase zien huisartsen de patiënt soms nog weinig, en dan vooral op het spreekuur. Dat verandert wanneer de terminale fase aanbreekt. Meestal nemen de lichamelijke en psychische problemen dan toe en is frequent bezoek van de huisarts noodzakelijk.

De huisarts werkt daarbij vaak nauw samen met verpleegkundigen van de thuiszorg. Bij patiënten die eerst curatief behandeld zijn, start het eerste contact met de thuiszorg vaak na het ziekenhuisontslag. Door contact met ziekenhuisverpleegkundigen of de huisarts wordt de thuiszorg op de hoogte gesteld van de stand van zaken en van de eventueel te verwachten problemen. Aansluitend zal een intakegesprek worden gevoerd met de patiënt om de behoefte aan zorg te inventariseren. De benodigde inzet voor thuiszorg wordt in Nederland formeel geindiceerd door het Centrum Indicatiestelling Zorg, terwijl in Vlaanderen de huisarts en de thuiszorg zelf bepalen welke zorg geleverd wordt. Ook als er nog geen lichamelijke zorg nodig is, kan een thuiszorgverpleegkundige in overleg met de patiënt en de huisarts besluiten een aantal huisbezoeken af te leggen, waarbij zij informatie en advies geeft over de zorg die geboden kan worden in de palliatieve fase. Daarnaast kan thuiszorg ingeschakeld worden voor de persoonlijke verzorging en verpleging (bijvoorbeeld voor wondverzorging of medicatietoediening).

Een belangrijk uitgangspunt voor palliatieve zorg thuis is dat de patiënt waar mogelijk de regie heeft. ${ }^{4}$ Dit betekent dat aan specifieke wensen van de patiënt tegemoet wordt gekomen. In de praktijk blijkt dat ernstig zieke patiënten beslissingen over de zorg en behandelingen nog wel eens overlaten aan hun naasten en/of de arts. Het is mede daarom belangrijk dat er goed overleg is tussen de 
betrokken zorgverleners, de patiënt en zijn naasten, zodat beslissingen in de lijn van de wensen van de patiënt worden genomen.

Een tweede uitgangspunt is dat palliatieve zorg een proactieve benadering vraagt. ${ }^{4}$ Die proactieve benadering (ook wel advance care planning genoemd; zie paragraaf 1.I) houdt onder meer in dat de betrokken zorgverleners anticiperen op problemen die kunnen gaan spelen. Bij het voortschrijden van de ziekte, verergeren vaak bestaande symptomen of ontstaan er nieuwe lichamelijke of psychische klachten.5 Het tijdig signaleren van problemen is belangrijk om crisissituaties en onnodige (ziekenhuis)opnamen te voorkomen. ${ }^{6}$ Door het verzwakken en minder mobiel worden van de patiënt zal de zorgbehoefte toenemen en daarmee ook de belasting van de mantelzorg. Zorgverleners die weten dat een dergelijke situatie kan komen, kunnen - onder de voorwaarde dat de patiënt en zijn naasten daar al aan toe zijn - tijdig bespreken wat de wensen van de patiënt voor de toekomst zijn. Relevante vragen daarbij zijn bijvoorbeeld: Wil de patiënt het liefst thuis blijven? Of staat men open voor een opname op bijvoorbeeld een palliatieve eenheid/afdeling of in een hospice als de situatie verslechtert? Wat verwachten de patiënt en de mantelzorgers hierin van de huisarts en de thuiszorg?

Ten derde is een uitgangspunt dat voor thuisverblijvende patiënten en hun naasten persoonlijke beschikbaarheid en aandacht van de huisarts en thuiszorgmedewerkers belangrijk zijn.4,7 Dit betekent dat waar mogelijk de zorg door dezelfde huisarts en dezelfde thuiszorgmedewerkers moet worden verleend. Omdat dat niet altijd haalbaar is, is het belangrijk om in een goede en volledige overdracht naar collega's te voorzien. In de overdracht moeten onder meer de huidige en te verwachten problemen van de patiënt zijn beschreven, evenals de afspraken met de andere betrokken zorgverleners en met de patiënt en zijn familie, de zorginterventies en het zorgbeleid.

Een vierde uitgangspunt is dat huisarts en thuiszorg speciale aandacht moeten hebben voor de draagkracht en ondersteuningsbehoeften van de mantelzorgers. ${ }^{4}$ Daarbij moeten zij zich ervan bewust zijn dat vooral vrouwelijke mantelzorgers het vaak moeilijk vinden om uit zichzelf aan te geven dat de zorg te zwaar wordt. Wanneer de zorg thuis tekort dreigt te schieten, worden in gezamenlijk overleg tijdig ondersteunende maatregelen genomen, zoals het inschakelen van vrijwilligers.

Een laatste uitgangspunt is dat huisarts en thuiszorg elkaar goed moeten informeren. ${ }^{4}$ Zodra gestart wordt met thuiszorg, moeten huisarts en de contactpersoon bij de thuiszorg (veelal een verpleegkundige) contact met elkaar opnemen. ${ }^{4}$ In deze en daaropvolgende contacten moet informatie uitgewisseld worden, zodat zowel de huisarts als de betrokken thuiszorgprofessionals op de hoogte zijn van onder meer:

- de actuele situatie van de patiënt;

= wat de patiënt weet (bijvoorbeeld over de diagnose en prognose) en wat de patiënt wil weten;

- afspraken met andere zorgverleners; 
= klachten, problemen, zorgbehoeften en -wensen;

- de medische (voor)geschiedenis;

n medicatie(beleid);

= relevante psychosociale gegevens;

= beschikbaarheid en draagkracht van de mantelzorgers.

Dergelijke informatie en afspraken tussen huisarts en thuiszorg worden vastgelegd in het zorgdossier/logboek dat bij de patiënt aanwezig is. In ieder geval wordt daarin ook verslag gedaan van elk contact met de patiënt. De huisarts en de thuiszorg stellen elkaar op deze manier op de hoogte van veranderingen in de toestand van de patiënt en van veranderingen in hun beleid.

\subsubsection{Consultatie- en ondersteuningsmogelijkkheden in Nederland}

Huisartsen, verpleegkundigen en verzorgenden van de thuiszorg en andere intra- en extramurale zorgverleners kunnen in Nederland in hun eigen regio een beroep doen op een zogeheten consultatieteam palliatieve zorg. De teams kunnen gebeld worden als een zorgverlener op problemen stuit in de zorg, behandeling of begeleiding van een patiënt. Een consultatieteam bestaat minimaal uit een huisarts-consulent of hospicearts, een medisch specialist (bijvoorbeeld een oncoloog) en een aantal gespecialiseerde verpleegkundigen. Het zijn allemaal mensen die gespecialiseerd zijn in de zorg voor mensen met een ongeneeslijke ziekte. De meeste teams kunnen tijdens kantoortijden gebeld worden, sommige ook in de avonduren en weekenden. De consultatievraag wordt in behandeling genomen door de dienstdoende verpleegkundige of arts. $\mathrm{Na}$ inventarisatie van de situatie volgt meestal binnen een halfuur, maar uiterlijk binnen 24 uur, een advies. Bij ingewikkelde vragen kan het team een beroep doen op een breed netwerk van specialistische disciplines, van anesthesiologen, maatschappelijk werkers en geestelijk verzorgers tot fysiotherapeuten en diëtisten.

Meestal blijven de consulenten op afstand van de patiënt; zij inventariseren de situatie telefonisch door zich te wenden tot de consulentvrager. Sommige teams komen in uitzonderlijke gevallen - op verzoek van de consultvrager - ook bij de zieke op bezoek, om zich nader te oriënteren op de situatie. Vooralsnog blijkt dat de meeste consultatievragen gaan over de behandeling van pijnklachten en andere lichamelijke symptomen (zoals verwardheid, obstipatie, misselijkheid en benauwdheid). Consultatieteams worden ook nu en dan gebeld over problemen op psychosociaal of spiritueel gebied. ${ }^{8}$ Anno 2011 zijn er ruim vijftig van dergelijke multidisciplinaire consultatieteams. ${ }^{9}$ Doorgaans zijn deze teams verbonden aan een regionaal netwerk palliatieve zorg (zie paragraaf 2.1) of een integraal kankercentrum (IKC).

Daarnaast kunnen generalistisch werkende huisartsen en thuiszorgmedewerkers ook een beroep doen op en samenwerken met thuiszorgtechnologieteams, die zich gespecialiseerd hebben in verpleegtechnische thuiszorg. Vooral de grotere 
thuiszorgorganisaties beschikken over dergelijke teams met gespecialiseerde verpleegkundigen die veel ervaring en deskundigheid hebben op het terrein van technische (be)handelingen, zoals infusietherapie, verzorgen van katheters, epidurale pijnbestrijding, bloedtransfusie en inbrengen van sondes.

Verder hebben de grotere thuiszorgorganisaties vaak ook gespecialiseerde oncologische thuiszorgteams en/of gespecialiseerde palliatieve thuiszorgteams. Dergelijke teams worden meestal bemand door gespecialiseerde oncologieverpleegkundigen met veel expertise om de patiënt en zijn naasten tijdens de laatste levensfase te adviseren en te ondersteunen. De verpleegkundigen komen bij de patiënt thuis en hebben niet alleen aandacht voor de behandeling van complexe lichamelijke klachten en verpleegtechnische handelingen, maar hebben ook ruime aandacht voor de psychische, sociale en/of spirituele problemen die zich bij de patiënt en/of zijn naasten kunnen voordoen.

Er zijn geen precieze cijfers over hoeveel thuiszorgtechnologieteams en gespecialiseerde oncologische/palliatieve thuiszorgteams er zijn. Op de website van Agora staan echter tientallen thuiszorgorganisaties die zich profileren op het gebied van palliatieve zorg, en die vaak ook een of meer van dergelijke teams in hun organisatie hebben. ${ }^{10}$

\subsubsection{Multidisciplinaire thuiszorgequipes in Vlaanderen}

In Vlaanderen spelen de multidisciplinaire thuiszorgequipes veelal een centrale rol bij de palliatieve zorg thuis." De begeleidingsequipes zijn verbonden aan de samenwerkingsverbanden voor palliatieve zorg; voor Vlaanderen 'netwerken' (zie paragraaf 2.1) en voor Wallonië en Brussel 'platformes' genoemd. Ieder regionaal palliatief samenwerkingsverband beschikt over of werkt samen met ten minste één multidisciplinaire begeleidingsequipe ter ondersteuning van de palliatieve zorg in de thuissituatie. De begeleidingsequipes leveren een bijdrage aan de palliatieve zorg, die aanvullend is op die van de eigen huisarts en andere betrokken eerstelijnszorgverleners. De equipes bezitten veel expertise omtrent alle aspecten van de palliatieve zorg en alle problemen die zich daarbij kunnen voordoen. In 1987 werd met multidisciplinaire begeleidingsequipes gestart, en momenteel zijn er circa dertig equipes, verspreid over Vlaanderen, Brussel en Wallonië. Met het verzekeringscomité van het RIZIV is een overeenkomst gesloten, die onder meer de samenstelling van de equipe beschrijft. ${ }^{12}$ Een equipe die actief is in een gebied met 200.000 inwoners, moet beschikken over een personeelskader van 2,6 fte's, bestaande uit twee verpleegkundigen en één huisarts met specifieke deskundigheid en ervaring in palliatieve zorg en administratieve ondersteuning. Met deze personele inzet moet de equipe in staat zijn om op jaarbasis minstens honderd patiënten te begeleiden. De equipes zijn permanent bereikbaar, dat wil zeggen 24 uur per dag en 7 dagen per week.

Om patiënten thuis de gewenste optimale zorg te kunnen bieden, geeft de equipe adviezen over allerlei aspecten van palliatieve zorg aan de betrokken zorgverleners. 
Hierbij kan onder meer gedacht worden aan adviezen over pijnbehandeling, bestrijding van allerlei symptomen, gebruik van gespecialiseerd materiaal (zoals pijnpompen), psychologische en morele ondersteuning en informatie aan de patiënt en zijn naasten over diagnose, behandeling en prognose. De multidisciplinaire begeleidingsequipe stelt haar expertise ter beschikking aan de huisartsen en andere professionals in de eerste lijn (bijvoorbeeld verpleegkundigen, apothekers, paramedici, levensbeschouwelijke begeleiders) en ook aan mantelzorgers en vrijwilligers. In overleg met en met toestemming van de betrokken zorgverleners kan de equipe in sommige gevallen ook zelf bepaalde aspecten van de palliatieve zorg van een patiënt thuis op zich nemen. De direct betrokken eerstelijnsprofessionals blijven echter, onder leiding van de huisarts van de patiënt, in elk geval zelf volledig verantwoordelijk voor de verzorging en de begeleiding van de patiënt.

Een verschil met de multidisciplinaire consultatieteams in Nederland (zie hiervoor) is dat de thuiszorgequipes in Vlaanderen een breder takenpakket hebben en zich op meer richten dan op consultverlening. Samenwerking bevorderen en overleg plannen met huisarts, thuisverpleegkundige en alle andere zorgverleners die aan het bed van de palliatieve patiënt komen, zijn ook essentiële taken voor de equipes. Daarnaast dient een equipe een goede organisatie en coördinatie van de palliatieve zorg thuis te bewerkstelligen (zie ook hierna). Tevens moet de equipe psychische en morele ondersteuning bieden aan de betrokken eerstelijnszorgverleners.

Een ander verschil met de Nederlandse consultatieteams (die zowel consultaties verlenen aan extramurale als aan intramurale zorgverleners) is dat de equipes zich uitsluitend richten op de zorg voor patiënten die thuis verblijven. 'Thuis' betekent echter niet dat de patiënt noodzakelijk in de eigen woning verblijft. Ook patiënten die bij familie of vrienden verblijven, of in een rustoord, verzorgingstehuis of 'beschut wonen project', komen in aanmerking voor begeleiding door de equipe.

\subsubsection{Coördinatie van zorg thuis}

Bij palliatieve zorg thuis zijn vaak verschillende personen met verschillende deskundigheden betrokken. Zodra verschillende partijen bij de zorgverlening betrokken zijn, is goede zorgcoördinatie cruciaal. Een zorgcoördinator wordt - als het goed is - in overleg met de patiënt en/of de mantelzorgers benoemd. Hierbij is het van groot belang dat de patiënt een goede relatie heeft met de betreffende zorgverlener. In sommige gevallen zal de huisarts de rol van zorgcoördinator op zich nemen, soms zal de rol ingevuld worden door een verpleegkundige van de thuiszorg, of (in Vlaanderen) door een professional van de thuiszorgequipe. In Nederland komen er ook op steeds meer plaatsen aparte functies voor 'casemanagers palliatieve zorg'. ${ }^{13}$ Deze casemanagers (ofwel zorgcoördinatoren) zijn vaak verbonden aan een regionaal netwerk palliatieve zorg (zie paragraaf 2.1). 
Een zorgcoördinator/casemanager kan de patiënt en zijn naasten op basis van inhoudelijke professionele kennis en de kennis van de lokale/regionale zorgvoorzieningen adviseren en begeleiden. Dit kan voorkómen dat patiënten en hun familie zelf de weg moeten vinden in een veelheid aan voorzieningen. De zorgcoördinator/ casemanager fungeert tevens als bewaker van goede communicatie en overdracht tussen de verschillende zorgverleners (huisarts, thuiszorg, gespecialiseerde teams/ equipes, maatschappelijk werker, geestelijk verzorger enzovoort). Door de regie van de zorgcoördinator/casemanager wordt de communicatie tussen de verschillende zorgverleners geoptimaliseerd. Hierdoor wordt ook een efficiënte inzet van mensen en middelen bevorderd. Deze professional draagt zorg voor een eenduidig beleid en bewaakt de gemaakte afspraken tussen de verschillende disciplines. De zorgcoördinator/casemanager heeft door het regelmatige contact met de patiënt, met diens centrale mantelzorgers en met professionele zorgverleners een 'spinin-het-web-functie' en kan tijdig inspelen op veranderende situaties en problemen, waardoor soms crisissituaties en opnamen voorkomen kunnen worden. Idealiter is de zorgcoördinator/casemanager een vast aanspreekpunt en continue factor voor de patiënt vanaf de diagnose 'ongeneeslijk ziek' tot het eind (overlijden en nazorg). In de ideale situatie werkt de zorgcoördinator/casemanager ook 'transmuraal', in de betekenis van zorgsetting-overstijgend. Hij/zij kan dan fungeren als 'smeerolie' binnen de palliatieve zorgketen, ter aanvulling en ondersteuning van alle betrokken professionals.

\subsubsection{Conclusie}

Huisartsen en thuiszorgmedewerkers zijn belangrijke professionals in de palliatieve zorg thuis. Belangrijke uitgangspunten daarbij zijn dat de patiënt waar mogelijk de regie over de zorg thuis moet blijven houden en palliatieve zorg thuis een proactieve benadering vereist. Ook zijn goede beschikbaarheid en aandacht van de huisarts en thuiszorgmedewerkers cruciaal, waarbij er ook veel aandacht moet uitgaan naar de draagkracht en ondersteuningsbehoeften van de mantelzorgers. Verder is belangrijk dat huisarts en thuiszorg veel investeren in uitwisseling van informatie, overdracht en zorgcoördinatie.

Voor zorgverleners die behoefte hebben aan ondersteuning en advies bij de (thuis)zorg voor mensen met een ongeneeslijke ziekte, zijn er in de laatste vijftien jaar veel voorzieningen bijgekomen. In Nederland valt daarbij te denken aan de adviezen van de multidisciplinaire consultatieteams en de ondersteuning door specialistische thuiszorgteams. In Vlaanderen stellen de multidisciplinaire begeleidingsequipes hun ruime expertise ter beschikking aan huisartsen, thuiszorgmedewerkers en andere eerstelijnsprofessionals. Op die manier kan palliatieve zorg thuis van een hoog niveau gerealiseerd worden. 


\section{LITERATUUR}

1 Cohen J., J. Bilsen, P. Hooft, et al. Dying at home or in an institution using death certificates to explore the factors associated with place of death. Health Policy, 2006, 78, 319-329.

2 Velden L.F.J, van der, A.L. Francke, L. Hingstman \& D.L. Willems. Sterfte aan kanker en andere chronische aandoeningen. Kenmerken in 2006 en trends vanaf 1996. NIVEL, Utrecht, 2007.

3 Akker P. van den, K. Luijkx \& S. van Wersch. Waar wilt u doodgaan? Keuzen en ovenvegingen. IVA, Tilburg, 2005.

4 Eizenga, W.H., M. de Bont, J.A. Vriezen, et al. Landelijke Eerstelijns Samenwerkings Afspraak Palliatieve Zorg. Huisarts en Wetenschap, 2006, 49, 308-312.

5 Graeff, A. de, G.M. Hesselman, R.J.A. Krol, et al. Palliatieve zorg: richtlijnen voor de praktijk. VIKC, Utrecht, 2006.

6 Korte-Verhoef, R. de \& S. Teunissen. Beter thuis sterven? Vroegsignalering door de thuiszorg bij patiënten in de palliatieve fase. UPC \& NPTN, Utrecht, 2009.

7 Borgsteede, S. End-of-life care in general practice in the Netherlands. Proefschrift. Vrije Universiteit, Amsterdam, 2006.

8 www.palliatievezorg.nl/page_2122.html. Geraadpleegd op 29 juni 2010.

9 www.palliatief.nl/ZorgKiezen/Persoortvoorziening/Consultatieenadvies/tabid/2538/Default. aspx. Geraadpleegd op 29 juni 2010.

10 www.palliatief.nl/ZorgKiezen/Persoortvoorziening/Thuiszorgorganisatie/tabid/2536/ctl/ ZorgKiezenDetails/mid/6630/ProductID/1205/Default.aspx. Geraadpleegd op 29 juni 2010.

11 Bijlage bij persbericht: Achtergrondgegevens MBE's of Multidisciplinaire BegeleidingsEquipes. Federatie Palliatieve Zorg Vlaanderen, 10 september 2009.

12 www.riziv.fgov.be/presentation/nl/missions/pdf/foldernl.pdf. Geraadpleegd op 29 juni 2010.

13 Werkgroep casemanagement in de palliatieve zorg. www.palliatief.nl/LinkClick.aspx?fileticket= ${ }_{3} \mathrm{R}_{3} \mathrm{Xm}_{9} g \mathrm{YYG}_{4} \% 3 \mathrm{~d} \&$ tabid=4057. Geraadpleegd op 29 juni 2010. 


\subsection{DAGCENTRA EN DAGBEHANDELING}

\section{Wim Distelmans}

Het is bekend dat ernstig zieke, ongeneeslijke patiënten thuis willen worden verzorgd en liefst tot het einde toe.' Toch aarzelen ze vaak om naar huis te gaan, uit angst het veilige ziekenhuismilieu te moeten verlaten. Er zijn nog maar weinig voorzieningen voor mensen die niet meer curatief behandelbaar zijn, maar die zich nog niet in de terminale fase van hun aandoening bevinden. Om aan deze behoefte te voldoen zijn er dagcentra ontwikkeld. ${ }^{2}$

\subsection{T Units voor dagzorg}

In het Verenigd Koninkrijk werden de eerste units voor dagzorg opgezet. Deze dagcentra bieden vooral psychosociale ondersteuning, symptoomcontrole en respijtzorg aan voor de familie. Op deze wijze worden ook de thuiszorg, de ziekenhuizen en palliatieve eenheden (hospices) ontlast. Het blijkt dat in het Verenigd Koninkrijk veel hospices het aantal plaatsen voor dagopvang uitbreiden en het aantal bedden verminderen. Bovendien is dagopvang kosteneffectief en kunnen de patiënten langer - liefst tot het einde - thuis blijven. ${ }^{3}$ Het eerste dagcentrum voor palliatieve patiënten ontstond in 1975 in Sheffield. Momenteel zijn in het Verenigd Koninkrijk ongeveer 250 dagcentra actief mét wachtlijsten. Vertaald naar België en Nederland zou dat overeenkomen met respectievelijk 40-45 dagcentra voor België en 65-70 voor Nederland.

De eerste dagcentra zagen in België het licht aan het eind van de jaren negentig. Momenteel bestaan er nog maar een vijftal dat een beperkte overheidssteun geniet. In Nederland bestaat het Belgische concept 'supportief dagcentrum', zoals hierna beschreven, ook nog maar op beperkte schaal. Anno 2011 is op één plaats in Nederland (in hospice Demeter in Bilthoven) deze vorm van dagzorg goed van de grond gekomen. Vaker ziet men in Nederland zogenoemde inloophuizen die ontmoetingscentra zijn voor onder meer mensen met kanker, voor naasten en nabestaanden. Toch is ook in Nederland de belangstelling voor deze waardevolle ondersteuning van de zorg thuis duidelijk aanwezig. In 2005 organiseerde Agora een studiedag rond palliatieve dagzorg waaruit duidelijk de noodzaak van dagcentra naar voren kwam.

\subsubsection{Dagcentra}

Dagcentra passen perfect in de ondersteuning van de thuiszorg. De centra fungeren als brugfunctie tussen ziekenhuis en thuiszorg. Ze bevorderen enerzijds de terugkeer naar huis vanuit het ziekenhuis en anderzijds kunnen patiënten hierdoor ook langer thuisblijven. ${ }^{4}$ Voor de 'langliggers' die aarzelen tussen de 'geborgenheid' van het ziekenhuis en het verlangen naar huis, kan het faciliterend werken. Tijdens hun 
hospitalisatie kunnen de patiënten af en toe naar het dagcentrum gaan. Zo vertrekken ze uit het ziekenhuis met de geruststelling dat zij thuis ook omringd blijven. Terug thuis kan de patiënt af en toe het dagcentrum bezoeken. De draagkracht van de familie en andere mantelzorgers blijft behouden en de zwaar zieke moet niet meer om de haverklap gehospitaliseerd worden: 'Een dagje uit voor de zieke en een dagje vrij voor de mantelzorg.'

Bovendien heeft de patiënt hier sociaal contact en kan hij eventueel ondersteunende behandelingen krijgen waarvoor hij anders naar het ziekenhuis moet: bloedtransfusies, wasbeurt in een hooglaagbed, psychologische ondersteuning. Alles kan en niets moet. Er hangt een luchtige, ontspannen sfeer, terwijl de professionals toch alert blijven voor eventuele fysieke en psychische problemen.

Het dagcentrum is complementair aan de thuiszorg en is gericht op 'leven'. De klassieke thuiszorg is er welkom: de kinesist/fysiotherapeut voor revalidatieoefeningen, de thuisverpleegkundige voor een wondverzorging, de huisarts voor een evacuerende punctie. Ook de rol van de talloze vrijwilligers is niet te onderschatten. Zij zijn complementair aan de professionals omdat ze hulp bieden die de zorgverleners binnen hun takenpakket niet kunnen invullen: sociale activiteiten inrichten zoals schilderen, handwerk; maaltijden bereiden; vervoer regelen voor sommige patiënten; problemen signaleren aan de professionelen enzovoort.

\subsubsection{Palliatieve zorg is meer dan terminale zorg}

Palliatieve zorg betekent meer dan terminale zorg. ${ }^{5,6} \mathrm{Bij}$ de palliatieve thuisequipes en de palliatieve eenheden in Vlaanderen (zie paragrafen 2.2 en 2.3 ) gebeurt de begeleiding gedurende weken, maximaal enkele maanden. Ook in de zelfstandige hospices of bijna-thuis-huizen zoals die in Nederland voorkomen (zie paragraaf 2.5), beslaat de palliatieve zorg meestal maar een beperkt aantal dagen of weken. Patiënten van een dagcentrum hebben in het algemeen een langere levensverwachting. ${ }^{7}$

Dit bewijst nogmaals dat 'palliatief' niet noodzakelijk 'terminaal' betekent. Het onderscheid blijkt kunstmatig en in de praktijk zijn de overgangen tussen curatief, palliatief en terminaal vaak onduidelijk. Kankerpatiënten met een recidief en een onzekere prognose kunnen in het dagcentrum evengoed tijdelijk op adem komen. Zo kunnen aidspatiënten die het psychisch zwaar hebben en weinig therapietrouw zijn, door een dagcentrum opnieuw gemotiveerd raken om strikt de antivirale therapie te volgen. Ze integreren daardoor opnieuw in de maatschappij en blijven soms geruime tijd weg uit het dagcentrum tot ze er opnieuw behoefte aan hebben.

Dankzij de beschikbaarheid van gekwalificeerde professionele zorgverleners kunnen dagcentra ook een bijdrage leveren aan het terugdringen van zinloos medisch handelen of therapeutische hardnekkigheid. De zin en onzin van actieve behandelingen kunnen op een bijna informele wijze besproken worden. Niet alleen voelen patiënten zich hierdoor gesteund, maar ook voor de thuisverzorgers biedt dit 
extra(murale) support. Vandaar dat men in Vlaanderen liever spreekt van 'supportieve dagcentra'.

Reguliere hulpverleners hebben tijd nodig om met het juiste profiel van een dagcentrumpatiënt vertrouwd te raken. Men denkt vaak nog te veel in het klassieke verwachtingspatroon van de geneeskunde: curatief behandelen en uitsluitend wanneer dit niet meer mogelijk is, worden de patiënten 'overgelaten' aan de palliatieve zorgequipes. Tussen de twee uitersten van enerzijds genezing en anderzijds terminale zorg blijft er het (grootste) grijze gebied van palliatie, namelijk het gebied van trial-and-error, van terugval, van emotionele ontwrichting, van hoop en wanhoop, van het zoeken en uitproberen van behandelingsmogelijkheden, van het aanpassen aan de nieuwe levensomstandigheden.

Buiten opvang van reeds vergevorderde patiënten, zijn dagcentra uitermate geschikt om patiënten vanuit dit grijze gebied van palliatie op te vangen. Bovendien zijn patiënten van een dagcentrum - in ieder geval in Vlaanderen - gemiddeld jonger en vaker met werkende partners dan de patiënten die door de andere palliatieve teams worden gevolgd. Omdat al deze patiënten gastvrij opgevangen worden, spreekt men in diverse dagcentra niet meer van patiënten maar van 'gasten'.

\subsubsection{Dagopvang voor palliatieve patiënten}

De aanbevelingen van de Raad van Europa zijn formeel: dagopvang moet zonder twijfel deel uitmaken van het zorgaanbod. ${ }^{8}$ Het volgende citaat komt in vertaling letterlijk uit deze aanbevelingen:

Patiënten kunnen een of meer dagen per week aanwezig zijn. De aangeboden voorzieningen kunnen medisch van aard zijn (bloedtransfusies, herziening van het beleid om pijn en symptomen onder controle te houden enz.) of sociaal (douche/bad), betrekking hebben op rehabilitatie (fysiotherapie, activiteitentherapie), ontspannend van aard zijn (massage) of gericht zijn op het verzetten van de zinnen (kunst en handvaardigheid). Ook bieden zij de primaire zorgverlener de mogelijkheid om wat vrije tijd te hebben.

\subsubsection{Gespecialiseerd personeel}

Supportieve dagcentra vereisen gespecialiseerd personeel. Oorspronkelijk werd er nog een onderscheid gemaakt tussen verschillende vormen van dagopvang:

n het sociale model, voornamelijk gebaseerd op respijtzorg voor de mantelzorg of om sociaal isolement tegen te gaan;

w het medische model, waarbij ook pijn- en symptoomcontrole worden toegepast;

- het therapeutische model, dat meer op een polikliniek lijkt met afspraken met specifieke professionals rond counseling, complementaire therapieën en dergelijke. 
Maar dit onderscheid wordt meer en meer verlaten ten gunste van een model van dagopvang waar elk aanbod mogelijk is, maar dat van dag tot dag kan verschillen, ook afhankelijk van welke patiënten aanwezig zijn. Hieruit blijkt de noodzaak om continu te kunnen beschikken over gespecialiseerde zorgverleners: verpleegkundigen met grondige kennis van palliatieve zorg, een psycholoog en een gespecialiseerd arts.

\subsubsection{Conclusie}

In een veranderende maatschappij met steeds minder mantelzorg is het belang van supportieve dagcentra niet te onderschatten. ${ }^{8}$ Het kerngezin wordt alsmaar kleiner en bestaat vaak uit twee werkende partners. Wanneer één van beiden ernstig ziek wordt, kan de werkende partner er overdag geen zorg voor dragen. Een 'verplichte' hospitalisatie kan door dagopvang soms vermeden worden. Aangezien mensen dankzij betere levensomstandigheden almaar ouder worden, hebben steeds meer mensen chronische en vaak levensbedreigende aandoeningen. Ook hier zal men intensief naar alternatieven voor residentiële voorzieningen moeten zoeken. Initiatieven zoals een supportief dagcentrum vormen een alternatief.

Dagcentra ondersteunen de thuiszorg en komen tegemoet aan de wens van veel ongeneeslijk zieke patiënten om thuis te kunnen blijven. Bovendien is deze opvang goedkoop als men het vergelijkt met een ziekenhuisopname. Men kan zich afvragen waarop de politiek wacht om deze opvang degelijk te financieren.

\section{LITERATUUR}

1 Distelmans, W., S. Bauwens, M. De Maegd, et al. Palliative day care in Belgium: from terminal care towards care for incurable patients. Palliative Medicine, 2004, 18, 375-376.

2 Fisher, R.A. \& P. McDaid. Palliative Day Care. Arnold, London, 1996.

3 Bekaert, R., M. De Maegd, R.M.J. De Neef, et al. TOPAZ, Recepten voor een beter leven(s)einde. Houtekiet, Antwerpen, 2007.

4 Hearn, J. \& K. Myers. Palliative Day Care in Practice. Oxford University Press, Oxford, 2001.

5 Distelmans, W., S. Bauwens, S. Storme \& T. Tielemans. Palliative day care in Belgium: first observations. European Journal of Palliative Care, 2005, 12, 170-173.

6 Distelmans, W. \& S. Bauwens. Palliative care is more than terminal care. Belgian Journal of Medical Oncology, 2008, 2, 16-20.

7 De Maegd, M., M. Rooze, M. Hoet, et al. Supportief dagcentrum TOPAZ. Jaarrapport 2010. TOPAZ, Wemmel, 2010.

8 Distelmans, W. Een waardig levenseinde, Ge druk. Houtekiet, Antwerpen, 2010. 


\subsection{ZELFSTANDIGE HOSPICEVOORZIENINGEN}

\section{Martine Wolfaert en Anneke Francke}

Het begrip hospice bestaat al lang. In de middeleeuwen werd de term al gebruikt. Het was in die tijd een pleisterplaats waar pelgrims terechtkonden voor onderdak, voedsel en verzorging en waar hulp gegeven werd aan stervenden. De bedoeling van de hospices uit de huidige tijd is een rustgevende plaats te zijn voor de opvang en voor de palliatieve zorg van mensen in de allerlaatste levensfase.

\subsubsection{Wat is een hospice?}

Een hospice is een huis - meestal in een gewone woonwijk - waar mensen palliatieve zorg krijgen. Men spreekt over een 'zelfstandig' of 'onafhankelijk' hospice als de hospicevoorziening geen onderdeel uitmaakt van een grotere zorgorganisatie (bijvoorbeeld een ziekenhuis of een verpleeghuis). Het is de bedoeling dat patiënten hier zo veel mogelijk 'thuis' komen. De sfeer wordt bewust huiselijk gehouden, dus er heerst geen ziekenhuissfeer. De gasten worden op een persoonlijke manier benaderd. Het personeel draagt geen uniformen en het eten wordt in een gewone keuken bereid. Er vinden geen routineonderzoeken of routinehandelingen plaats. De patiënten (meestal gasten genoemd) worden volgens hun eigen ritme verzorgd. Ze kunnen aangeven wat voor hen belangrijk is, ze kunnen kiezen om al dan niet uit te slapen, om al dan niet te eten, in bad te gaan, enzovoort. Het concept wordt bewust kleinschalig gehouden; meestal is er plaats voor tussen de twee en de acht gasten.

\subsubsection{Aantallen hospices in Vlaanderen en Nederland}

Sterk beïnvloed door de al wat langer bestaande hospicebeweging in het Verenigd Koninkrijk en de Verenigde Staten, zijn er in de afgelopen tien tot vijftien jaar in Nederland veel hospices gekomen. In 2011 waren er in Nederland volgens de registraties van Agora ruim honderd zelfstandige hospices, waarbij er zes zich uitsluitend op kinderen richten (kinderhospices).

In Vlaanderen is er op dit moment één zelfstandig hospice, het Coda Hospice, gelegen in de Antwerpse Noorderkempen. Er zijn in Vlaanderen daarnaast wel veel palliatieve eenheden die in ziekenhuizen gevestigd zijn (zie paragraaf 2.2).

\subsubsection{Low-care en high-care hospices}

In Nederland wordt een onderscheid gemaakt tussen high-care en low-care hospices. De laatste worden ook wel bijna-thuis-huizen of vrijwilligershospices genoemd. De high-care hospices hebben vaste verpleegkundigen in dienst, en soms is er ook een eigen hospicearts (ook het Coda Hospice in Vlaanderen heeft een vaste staf met professionele zorgverleners). Deze vaste professionals worden ondersteund door vrijwilligers. Voor de zelfstandige high-care hospices is in Nederland een kwaliteitssysteem 
ontwikkeld, waar een certificering en een onafhankelijke toetsing aan zijn verbonden. In dit kwaliteitssysteem staan normen beschreven met betrekking tot de kwaliteit van het proces en de organisatie van de palliatieve zorg. ${ }^{2}$

De low-care hospices werken vooral met vrijwilligers en hebben geen eigen verpleegkundigen of andere professionals in dienst. Deze vrijwilligers zijn gemotiveerde mensen (meestal vrouwen), die helpen bij de verzorging en bij huishoudelijke klussen zoals koken, schoonmaken en wassen. Verder zijn ze luisterend aanwezig met veel aandacht voor de problemen van gasten en hun families. Hun inzet is afhankelijk van hun mogelijkheden en hun keuze, variërend van enkele uren tot dagen per week. Op de inzet van vrijwilligers wordt nog verder ingegaan in paragraaf 3.6.

In de low-care hospices blijft de eigen huisarts van de gast verantwoordelijk voor de medische zorg en waar nodig komen er thuiszorgmedewerkers over de vloer voor verpleegkundige taken.

\subsubsection{De ambiance}

Hospices zijn huiselijk ingericht. De kamers hebben vaak een verstelbaar bed, een makkelijke stoel en tv. Ook is er meestal een privébadkamer en een wc. Veelal is er ook een gezamenlijke woonkamer. Gasten kunnen daar bezoek ontvangen, lezen of naar muziek luisteren. Gasten die dat willen, kunnen er vaak ook samen eten, met elkaar, hun familie of met medewerkers.

In de hospices wordt veel aandacht gegeven aan lekker eten. De vrijwilligers doen er veel aan om aan de wensen van de patiënt op het gebied van eten en drinken te voldoen. Versieren van een tafel met een bloemetje, het mooi schikken van eten op een bord horen daar ook bij.

Afhankelijk van de individuele behoefte, is er vaak ook een mogelijkheid tot aanvullende zorg, zoals ontspanningsoefeningen, ontspannende massage, pedicure, kapper, esthetische verzorging en fysiotherapie (kinesitherapie).

\subsubsection{Soorten en aantal gasten en duur verblijf}

De meeste gasten in een hospice hebben ongeneeslijke kanker en kunnen vaak niet meer thuis verzorgd worden omdat er geen mantelzorg beschikbaar is of de zorg voor de familie te zwaar wordt. Meestal verblijven gasten er tot en met het overlijden, maar sommige komen voor een vastgestelde periode van een paar dagen of enkele weken. Daardoor kan de familie tijdelijk ontlast worden van de zorg. Bij een tijdelijk verblijf worden problemen (lichamelijke, sociale of emotionele) soms verminderd, waardoor men de kracht vindt om terug naar huis te gaan. Een paar hospices leveren ook dagopvang (zie ook paragraaf 2.4).

In het ene hospice in Vlaanderen verblijven jaarlijks ongeveer 110 gasten. $\mathrm{Ze}$ verblijven er gemiddeld achttien dagen. Er is niet precies bekend hoeveel gasten er verblijven in de circa honderd zelfstandige hospices in Nederland. Geschat wordt dat het daarbij om een paar duizend gasten per jaar gaat. ${ }^{3}$ De gemiddelde opnameduur is 
rond de maand. In het algemeen varieert de opnameduur tussen een dag en enkele maanden. ${ }^{4}$

\subsubsection{Begeleiding van de familie}

In de hospices geeft men de familie de kans om zo veel mogelijk betrokken te blijven bij de zorg. Ook bij de verzorging na het overlijden, kan de familie helpen wanneer zij dit wenst. Dierbaren krijgen ruimschoots de tijd om na het sterven afscheid te nemen van de overledene.

De zorg voor de familieleden is niet afgelopen bij het overlijden van de gast in een hospice. Er is vaak een band gegroeid tussen familieleden en medewerkers. In veel hospices zijn er ook bijeenkomsten om overleden gasten te herdenken. Hierbij worden soms ook nabestaanden uitgenodigd. Sommige hospices organiseren ook rouwgroepen waarin nabestaanden (onder begeleiding) de gelegenheid krijgen om ervaringen te delen.

\subsubsection{Conclusie}

Uit onderzoek is bekend dat als om een of andere reden thuis sterven niet mogelijk is, mensen dan het liefst sterven in een omgeving die zo veel mogelijk op thuis lijkt. ${ }^{5}$ Hospices bieden zo'n huiselijke omgeving. Zorgverleners stellen in de hospices de gast centraal en spannen zich sterk in om de wensen van de gast en de naaste familie te vervullen.

\section{LITERATUUR}

1 www.palliatief.nl/ZorgKiezen/Persoortvoorziening/tabid/221o/Default.aspx. Geraadpleegd op 29 juni 2010.

2 www.perspektkeurmerk.nl/index.php?id=254. Geraadpleegd op 29 juni 2010.

3 Velden L.F.J. van der, A.L. Francke, L. Hingstman \& D.L. Willems. Sterfte aan kanker en andere chronische aandoeningen. Kenmerken in 2006 en trends vanaf 1996. NIVEL, Utrecht, 2007.

4 Mistiaen P., L. van Ruth \& A.L. Francke. Monitor palliatieve zorg; rapport 2006 en bevindingen over drie jaar monitor. NIVEL, Utrecht, 2006.

5 Akker P. van den, K. Luijkx \& S. van Wersch. Waar wilt u doodgaan? Keuzen en overwegingen. IVA, Tilburg, 2005 . 


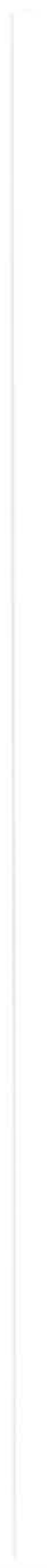




\section{De actoren in het veld van de palliatieve zorg}

3.1 De houding van verpleegkundigen in de palliatieve zorg $\quad 70$

3.2. Competenties van verpleegkundigen in de palliatieve zorg $\quad 76$

3.3 Samenwerking van verpleegkundigen en artsen $\quad 85$

3.4 De rol van pastores 92

3.5 De rol van de psychosociale hulpverleners 97

3.6 De rol van familiezorgers en vrijwilligers 103 


\subsection{DE HOUDING VAN VERPLEEGUNDIGEN IN DE PALLIATIEVE ZORG}

\section{Gert Olthuis}

Volgens het gerenommeerde Oxford-handboek voor palliatieve geneeskunde van Doyle e.a. vertrekt de palliatieve zorg vanuit drie uitgangspunten.' Allereerst gaat het om de kwaliteit van leven zoals die ervaren wordt door de patiënt. Vervolgens is de waarde die aan dat leven wordt gehecht, ongeacht hun (economische) bijdrage aan de samenleving, een uitgangspunt bij de zorg voor ongeneeslijk zieke mensen. Tot slot zijn vaak ook zingevingsvragen onlosmakelijk verbonden met zorg in de laatste fase van het leven. Wat direct opvalt is dat niet zozeer de dood centraal staat bij zorg in de stervensfase, maar dat juist het leven benadrukt wordt.

Tot deze conclusie komen bijvoorbeeld ook de journalisten Pauline de Bok en Mirre Bots, die beiden als vrijwilliger in de palliatieve zorg zijn gaan werken om het sterven van mensen beter te kunnen begrijpen., ${ }^{2,3}$ Maar terwijl ze allebei de nabijheid van de dood zochten, kwamen ze ook tot de overtuiging dat het sterven niet is los te zien van het leven: 'De meeste mensen sterven zoals ze geleefd hebben.'

Zorg aan het einde van het leven is een bijzonder soort van zorg. Het is zorg die zich afspeelt op de flinterdunne grens tussen het geleefde leven en het moment waarop dit ophoudt. Dat vraagt van zorgverleners die palliatief zorgen een speciale houding waarmee ze die zorg verlenen. In deze paragraaf zal duidelijk worden dat die houding in de kern een morele houding is die nauw verbonden is met hoe de zorgverlener zelf in het leven staat. Voordat we daar verder op ingaan, schetsen we eerst kort een aantal bijzondere kenmerken die het verlenen van zorg aan het levenseinde met zich meebrengt.

\subsubsection{Van aanvaarden naar welzijin}

Een eerste kenmerk van de houding van zorgverleners in de palliatieve zorg is de rol die 'aanvaarden' speelt. ${ }^{4}$ In de hedendaagse gezondheidszorg vormen het niet aanvaarden van sterven en dood, het streven naar levensverlenging en het leveren van strijd tegen ziekte de uitgangspunten van veel beslissingen en behandelingen. Hoewel die 'actieve' invalshoek veel goeds teweeg heeft gebracht, zijn juist het accepteren en het niet onnodig uit willen stellen van de dood karakteristiek voor de palliatieve zorg. Deze houding van aanvaarden heeft ook gevolgen voor de wijze waarop palliatieve zorg verleend wordt. Niet 'doen' en 'ingrijpen' vormen hier de leidraad, maar veeleer 'afwachten', 'aanwezig zijn' en 'laten gebeuren'.

Een tweede kenmerk heeft te maken met de ongrijpbaarheid van de dood. Want het aanvaarden van het levenseinde mag dan een aspect zijn van palliatieve 
zorg, de dood wordt daarmee nog niet een te begrijpen fenomeen. Er blijft een moment van dubbelzinnigheid in onze omgang met de dood zitten; het einde is niet te vermijden, maar ook niet te bevatten. De meest zuivere omgang met de dood is misschien wel een benadering die streeft naar een zo goed mogelijke zorg voor het levenseinde, met oog voor die dubbelzinnigheid. ${ }^{5}$ Het omgaan met deze dubbelzinnigheid vraagt om bepaalde kwaliteiten, om een bepaalde houding vanwaaruit de laatste zorg wordt verleend. Centraal staan daarin onder meer toewijding, geraakt durven worden door andermans lijden, een luisterend oor bieden en respect hebben voor de visie van patiënten op kwaliteit van leven.

Deze twee kenmerken geven aanleiding tot een derde cruciaal aspect aan de houding die het verlenen van palliatieve zorg vereist. Palliatieve zorg is zorg die niet alleen een beroep doet op de specifieke deskundigheid van de zorgverlener met betrekking tot symptoombestrijding of andersoortige medische of verpleegkundige interventies, maar die een beroep doet op de zorgverlener als mens. ${ }^{6}$ Alles in de palliatieve zorg is erop gericht de patiënt zich zo comfortabel mogelijk te laten voelen; het welzijn van de patiënt staat centraal. Het doel is kwaliteit van leven te bewerkstelligen in zowel fysieke zin als op het emotionele, relationele en spirituele vlak. Dat betekent dat palliatieve zorg een expertise vereist die zorgverleners in staat stelt te zorgen voor 'de hele persoon'. Veel van wat palliatieve zorgverleners kunnen betekenen voor patiënten houdt verband met de relatie die ze aangaan met de patiënten voor wie ze zorgen.

Deze persoonlijke inzet van zorgverleners in de palliatieve zorg kan worden gekenschetst als een morele houding, waarvan de kern wordt gevormd door de motivatie en betrokkenheid om in het belang van het welzijn van anderen te handelen. Een houding dus die erop gericht is het goede te doen voor mensen die geconfronteerd worden met het einde van het leven, maar die tegelijkertijd nauw verbonden is met de persoon van de zorgverlener zelf.,, 8

\subsubsection{De morele houding van palliatieve zorgverleners}

Verpleegkundigen die de keus maken om hun werkzame leven te wijden aan palliatieve zorg, doen dat niet zomaar. Vaak zijn ze op het spoor gezet van de zorg voor ongeneeslijk zieke mensen doordat bepaalde gebeurtenissen in hun persoonlijke of professionele leven hen hebben geraakt. Dat kan bijvoorbeeld te maken hebben met een sterfgeval in hun directe omgeving dat moeilijk of misschien juist heel mooi verliep. Het kan ook zijn dat een moeizame omgang met doodzieke patiënten in de reguliere zorg de motivatie vormt voor de palliatieve zorg te kiezen. Een 
verpleegkundige vertelde het volgende over haar beslissing om in een hospice te gaan werken:

Het mysterie van het afscheid nemen, het feit dat de dood voor eeuwig is en de gedachte aan wat daarna komt, hebben me altijd gefascineerd. Dat is heel persoonlijk en is verbonden met wie ik ben. Wat me deed besluiten de stap te zetten het ziekenhuis te verlaten en in een hospice te gaan werken, was toen ik me afvroeg: Wat geeft me energie op het werk? Wanneer kom ik thuis en voel ik me goed? Dat was wanneer ik met patiënten kon praten over hoe ze hun ziekte beleven en hoe ze daarmee omgaan, wanneer ik hun familie kan bijstaan en ze kan uitleggen wat er aan de hand is. ${ }^{8}$

De bereidheid patiënten bij te staan in hun levenseinde en in het belang van hun fysieke, psychosociale en spirituele welzijn te handelen, houdt in dat de menselijke kwaliteiten van palliatieve zorgverleners van doorslaggevende betekenis zijn voor de kwaliteit van zorg. De relatie tussen patiënt en zorgverlener vormt de basis voor de zorg voor de hele persoon. Omdat dit een relatie is waarin de patiënt afhankelijk is van de zorgverlener, zijn er twee morele voorwaarden waaraan die relatie moet voldoen wil ze haar doel (het welzijn van de patiënt) niet missen. Ten eerste moet er sprake zijn van betrokkenheid van de zorgverlener bij wat goed is voor deze ene patiënt. Op de tweede plaats is het een voorwaarde dat de patiënt vertrouwen heeft in die betrokkenheid. Dat vertrouwen wordt het best mogelijk gemaakt wanneer de betrokkenheid bij 'het goede voor deze patiënt' de essentie vormt van wat het betekent om een palliatieve zorgverlener te zijn. ${ }^{9}$ In deze paragraaf voegen we nog een derde begrip toe: wederkerigheid. Precies omdat het in de palliatieve zorg vaak diep menselijke, intieme relaties betreft, is de zorg niet alleen betekenisvol voor patiënten, maar ook voor zorgverleners. Om een beter inzicht te krijgen in de morele houding van palliatieve zorgverleners, lopen we deze drie morele kenmerken - betrokkenheid, vertrouwen en wederkerigheid hieronder een voor een langs.

\section{Betrokkenheid}

Zorgen begint met het moment waarop iemand oog heeft voor de noden van een ander. Dat geldt ook voor palliatieve zorg. In ethische termen betekent dit dat zorgen begint bij de morele waarde van de aandacht. Zorg verlenen begint wanneer iemand opmerkzaam is, belang stelt in de ander en in zijn omgeving, en de signalen oppikt waarmee de behoefte aan zorg van iemand duidelijk wordt. ${ }^{10} \mathrm{Met}$ andere woorden: het zorg verlenen vangt aan wanneer de zorggever zich betrokken toont bij de zorgontvanger door aandacht te hebben voor de situatie waarin deze zich bevindt. Dat deze betrokkenheid soms heel vanzelfsprekend kan zijn, 
wordt duidelijk uit de volgende opmerking van een psycholoog die werkzaam is in een hospice:

Toen ik nog student was, leerde ik een oudere vrouw kennen die borstkanker had. Ik bezocht haar wekelijks en was onder de indruk van de wijze waarop ze in het leven stond en omging met haar ziekte. Ik herinner me dat ik haar vroeg: ' $\mathrm{k}$ weet waarom ik hier graag kom, maar wat hebt u eraan te praten met zo'n onervaren iemand als ik?' Ze vertelde dat ik één van de twee personen was met wie ze kon praten over haar ervaringen met haar ziekte. Ik was verbaasd. Ze zei dat de meeste mensen kwamen met clichés of over een ander onderwerp begonnen. ${ }^{8}$

Maar betrokkenheid bij het welzijn van een patiënt kan ook op grenzen stuiten. Je kunt zo goed mogelijk oog proberen te hebben voor de actuele situatie waarin iemand verkeert, maar soms weet je niet wat je losmaakt met een bepaalde vraag of opmerking. Zorg aan het levenseinde vraagt daarom om een continue bedachtzaamheid (aandacht!) op de complexiteit van het leven waar het om gaat, vindt een hospicearts:

Mensen dragen een heel leven met zich mee en ik heb niet de illusie dat ik ze altijd ken. Soms wordt iemand onverwacht heel angstig en weet je niet wat je hebt losgemaakt. Je moet altijd gevoelig blijven voor het feit dat situaties van verlies en gesprekken daarover niet logisch zijn. ${ }^{8}$

\section{Vertrouwen}

Als een patiënt geen vertrouwen heeft in een zorgverlener, dan kan het lastig zijn het goede te doen met het oog op het welzijn van die patiënt. Een eerste punt van belang voor het krijgen van vertrouwen is dat duidelijk is dat een zorgverlener de relatie met de zorgontvangende patiënt vanuit zichzelf en als zichzelf aangaat. De volgende uitspraken van verpleegkundigen uit de palliatieve zorg geven aan dat openheid en zelfkennis hier een cruciale rol spelen:

Ik ben toegankelijk. Mensen vertrouwen me snel en ik kan en mag dichtbij ze komen. Ik ben niet bang voor intimiteit. Ik durf vragen te stellen en durf dingen te zeggen en zaken te benoemen die me opvallen. Dat opent deuren, merk $i k$. Bovendien ben ik niet bang voor emoties en tranen. Dat komt, vermoed ik, doordat ik zelf veel heb meegemaakt. $l k$ heb in het verleden veel problemen met relaties gehad en heb daardoor veel over mezelf nagedacht. ${ }^{8}$ 
Palliatieve zorg gaat over waarden die ik zelf belangrijk vind in het leven. Waarden waar ikzelf mee geworsteld heb: dat je mag zijn wie je bent. Ik merk dat hoe meer ik mezelf ben, hoe meer ik anderen uitnodig dat ook te zijn. Ik probeer daarbij respect te hebben voor iemand zonder te oordelen. ${ }^{8}$

Een ander punt van aandacht bij het krijgen van vertrouwen is de noodzaak continu oog te hebben voor hoe de ontvangende partij op de gegeven zorg reageert. Zoals hierboven is aangegeven: een zorgrelatie is een relatie tussen ongelijken waarbij de één afhankelijk is van de ander. Om te zien of de zorg adequaat is (geweest), is het belangrijk dat zorgverleners ontvankelijk zijn voor de reactie die hun betrokkenheid teweeg heeft gebracht. Een maatschappelijk werker van een palliatieve zorgafdeling vat samen wat dit betekent:

lemands gezichtsuitdrukking geeft aanwijzingen. Zijn er tranen of niet? Hoe raakt een patiënt je aan? Hoe kijkt hij naar je? Dat zijn zaken die je vertellen hoe iemand zich voelt. Je moet oog hebben voor deze signalen en voor de ervaringen van de familie. ${ }^{8}$

\section{Wederkerigheid}

Kenmerkend aan de morele houding in de palliatieve zorgverlening is de erkenning dat mensen overal en altijd deel uitmaken van een netwerk van menselijke relaties. Als zorgverlener maak je ook deel uit van dat netwerk en dat makkt de betrokkenheid vanwaaruit je zorg verleent er één van medemenselijkheid. Het concrete appèl dat de zorgontvanger op je doet als zorgverlener, maakt dat je verbonden bent met het leven van een andere persoon. ${ }^{10}$ Die verbondenheid leidt vaak tot wederkerigheid; in het zorgen voor iemand anders geef je niet alleen, maar ontvang je ook. De volgende citaten - eerst van een psycholoog en vervolgens van twee verpleegkundigen - geven daar blijk van:

Ik heb me vaak afgevraagd waarom ik in de palliatieve zorg werk. Wat me bevalt is dat het makkelijk is om in contact te komen met mensen over zaken die essentieel zijn. Je komt in contact met de essentie van mensen. Ik realiseerde me eerder dat ik niet groeide op mijn oude werkplek, terwijl ik in de palliatieve zorg voortdurend groei. Het lijkt wel of palliatieve zorg het beste in me naar boven brengt en een beroep doet op de kern van mijn mens-zijn. ${ }^{8}$ 
Ik zorgde eens voor een vrouw en de nacht dat ze stierf heb ik samen met haar dochters de laatste zorg verleend. Ik kwam om zes uur's ochtends thuis en voelde me enorm gelukkig. Het was zo speciaal de mogelijkheid te hebben hier deel van uit te maken. Ik realiseerde me dat ik getuige was geweest van een diep en intiem moment. Je verliest je moeder per slot van rekening maar één keer. Dat is ook precies het verschil met andere takken van zorg. ${ }^{8}$

Je laat veel van jezelf zien, maar dat staat in geen verhouding tot wat patiënten jou laten zien. In een paar weken tijd komen zoveel aspecten van een heel leven voorbij: verdriet, ellende, ruzies, onbegrip, liefde. Daar maak je opeens deel van uit. Dat is de toegevoegde waarde van palliatieve zorg. ${ }^{8}$

\subsubsection{Conclusie}

Deze paragraaf brengt de morele houding van zorgverleners in de palliatieve zorg in beeld. Als het bovenstaande één ding duidelijk heeft moeten maken, dan is het wel dat de kern van de palliatieve zorg gevormd wordt door de relaties waarmee mensen onderling verbonden zijn. Dat betekent dat goede zorg aan het levenseinde niet kan zonder de persoonlijke betrokkenheid van zorgverleners, het vertrouwen daarin van patiënten en het besef dat medemenselijkheid de drijvende kracht is achter deze zorg.

\section{LITERATUUR}

1 Doyle, D., G. Hanks, N. Cherny \& K. Calman (eds.). Oxford Textbook of Palliative Medicine. Oxford University Press, Oxford, 2005.

2 Bok, P, de. Doodsberichten. Meulenhoff, Amsterdam, 1999.

3 Bots, M. De cirkel voltooien. Levensiessen in het hospice. Altamira-Becht, Haarlem, 2007.

4 Teunissen, S. \& D. Willems. Het eigene van de palliatieve zorg. In: Spreeuwenberg, C., D.J. Bakker, G.H. Blijham, et al. (red.). Handboek palliatieve zorg. Elsevier gezondheidszorg, Maarssen, 2002, 29-71.

5 Leget, C. Van levenskunst tot stervenskunst. Over spiritualiteit in de palliatieve zorg. Lannoo, Tielt, 2008 .

6 Bruntink, R. Een goede plek om te sterven. Palliatieve zorg in Nederland. Plataan, Zutphen, 2002.

7 Olthuis, G. Persoon en professional. Professionele competentie in de palliatieve zorg in ethisch perspectief. In: Verkerk, M. \& R. Hartoungh (red.). Ethiek en palliatieve zorg. Van Gorcum, Assen, $2003,93-107$.

8 Olthuis, G. Who cares? An ethical study of the moral attitude of professionals in palliative care practice. Proefschrift. Radboud Universiteit, Nijmegen, 2007.

9 Randall, F. \& R. Downie. Palliative Care Ethics. A companion for all specialties. Oxford University Press, Oxford, 1999.

10 Nistelrooy, I. van. Basisboek zorgethiek. Over menslievende zorg, moreel beraad en de motivatie van verpleegkundigen. Abdij van Berne, Heeswijk, 2008. 


\section{Thirza Olden}

Verpleegkundigen in alle werkvelden van de gezondheidszorg kunnen te maken krijgen met patiënten die palliatieve zorg nodig hebben. In de initiële opleiding (ofwel de basisopleiding) tot verpleegkundige hoort het verlenen van palliatieve zorg dan ook tot de verplichte lesstof; verpleegkundigen hebben hier specifieke vaardigheden en kennis voor nodig. Iedere verpleegkundige moet na zijn of haar diplomering in staat zijn om (basale) palliatieve zorg te verlenen en weten waar meer gespecialiseerde kennis en ondersteuning te vinden is. In vervolgopleidingen kunnen verpleegkundigen die frequent te maken hebben met palliatieve zorg, zich op dit gebied verder specialiseren.

In deze paragraaf wordt ingegaan op de competenties van en onderwijs aan verpleegkundigen op het gebied van de palliatieve zorg. Onder competenties verstaan we het totaal van kennis, vaardigheden en attitude. Er wordt achtereenvolgens stilgestaan bij:

in de inhoud van de beroepsprofielen;

in competenties van verpleegkundigen;

iil onderwijs aan verpleegkundigen;

in toekomstige ontwikkelingen.

\subsubsection{Beroepsprofielen en opleidingsdocumenten}

De afgelopen jaren zijn verschillende publicaties op het gebied van de palliatieve verpleegkunde verschenen die betrekking hebben op de competenties van en onderwijs aan verpleegkundigen in de palliatieve zorg. Het doel van deze publicaties is duidelijkheid te bieden over wat verpleegkundigen nu precies moeten weten, kunnen en doen in de palliatieve zorg aan patiënten. De meest toonaangevende publicaties worden hieronder kort beschreven.

" Beroepsdeelprofiel verpleegkundigen werkzaam in de palliatieve zorg:" Het beroepsprofiel voor verpleegkundigen werkzaam in de palliatieve zorg is een verbijzondering van het algemene beroepsprofiel voor verpleegkundigen. Het is een eerste aanzet om binnen bestaande kaders (een algemeen beroepsprofiel) de specifieke taken en werkzaamheden van verpleegkundigen in de palliatieve zorg te beschrijven.

- A Guide for the Development of Palliative Nurse Education In Europe: ${ }^{2}$ De European Association for Palliative Care (EAPC) ontwikkelde Europese richtlijnen voor het opleidingstraject van verpleegkundigen in de palliatieve zorg. In dit document worden drie niveaus van palliatieve verpleegkunde beschreven, inclusief de bijbehorende competenties. Het gaat uit van de gedachte dat iedere verpleegkundige basisvaardigheden moet bezitten om in voorkomende gevallen palliatieve zorg te verlenen. Ook worden de meer gevorderde en specialistische verpleegkundige competenties beschreven. Daarnaast wordt ingegaan op de dimensies van het 
leerproces in palliatieve zorg en worden er uitspraken gedaan over hoe onderwijs over palliatieve zorg voor verpleegkundigen eruit zou moeten zien.

* Het kwaliteitskader voor het opleiden van verpleegkundigen in de palliatieve zorg: ${ }^{3}$ In 2008 zijn beide bovenstaande documenten samengevoegd in een groot competentieoverzicht. In het kwaliteitskader worden de competenties beschreven waaraan verpleegkundigen werkzaam in de palliatieve zorg, moeten voldoen. Deze beschrijving vindt plaats op drie deskundigheidsniveaus: (A) initieel, (B) gevorderd en (C) specialistisch opgeleide verpleegkundigen. De kerntaken en dimensies van palliatieve zorg worden beschreven.

Een gemeenschappelijk kenmerk van deze drie documenten is dat ze ingaan op de noodzakelijke competenties van verpleegkundigen die palliatieve zorg verlenen. Hierna worden deze competenties toegelicht.

\subsubsection{Specifieke competenties van verpleegkundigen in de palliatieve zorg}

'Palliatieve zorg is een benadering die de kwaliteit van het leven verbetert van patiënten en hun naasten die te maken hebben met een levensbedreigende aandoening door het voorkomen en verlichten van lijden, door middel van vroegtijdige signalering en zorgvuldige behandeling van pijn en andere problemen van lichamelijke, psychosociale en spirituele aard'. ${ }^{4}$ In de palliatieve zorg betekent dit dat:

" niet de genezing het doel is, maar een zo hoog mogelijke kwaliteit van leven;

III de dood als een normaal, natuurlijk proces wordt gezien;

= er aandacht is voor lichamelijke en psychische klachten;

= de psychologische en spirituele aspecten van zorg geïntegreerd worden benaderd;

iv emotionele ondersteuning wordt gegeven aan de patiënt en zijn naasten om zo actief mogelijk te leven;

- indien nodig vanuit een team zorgverleners gewerkt wordt, zodat aan alle noden van patiënten en naasten tegemoet kan worden gekomen;

= indien nodig de zorg zich ook uitstrekt tot na het overlijden van de patiënt (ondersteuning bij verliesverwerking).

De genoemde definitie en uitgangspunten van palliatieve zorg sluiten aan bij de kenmerken van de specifieke competenties die verpleegkundigen in de palliatieve zorg moeten bezitten. Het gaat dan om vijf punten.

1 Integrale zorg: de totale zorg voor de ongeneeslijke patiënt komt in de palliatieve zorg aan de orde; de zorg van verpleegkundigen richt zich op de lichamelijke, psychosociale én spirituele behoeften en problemen van de patiënt en zijn naasten.

2 Multidisciplinaire zorg: verpleegkundigen werken met diverse disciplines samen om deze integrale zorg vorm te geven, onder andere met (huis)artsen, collegaverpleegkundigen en verzorgenden, geestelijk verzorgers en maatschappelijk werkers, fysiotherapeuten. Juist door intensief als team samen palliatieve zorg te verlenen, wordt aan de behoeften van de patiënt tegemoet gekomen. 


\section{Box 1 Palliatieve zorg in verschillende werkvelden}

Op de cardiologische afdeling van een ziekenhuis werkt Petra als verpleegkundige. Veel van haar patiënten genezen niet meer van hun aandoening en bijna wekelijks vindt er een sterfgeval plaats op haar afdeling. Een van haar patiënten is Joop, een man van 67 jaar die enkele jaren geleden voor het eerst op haar afdeling is opgenomen met een hartinfarct. In de loop van de tijd heeft hij daarnaast decompensatio cordis ontwikkeld en is hier met enige regelmaat voor opgenomen. Langzaamaan gaat zijn conditie achteruit en Petra denkt erover om, in overleg met Joop en zijn behandelaar, gericht palliatieve zorg te gaan inzetten. Janny is verpleegkundige en werkt als groepsbegeleider in een woongroep voor verstandelijk gehandicapten. Een van de bewoners, Peter, is een tijdje geleden gediagnosticeerd met kanker in de buik met uitzaaiingen in de lever. Naast echo- en bloedonderzoeken is besloten Peter niet te belasten met zware en invasieve onderzoeken en een beleid te kiezen gericht op kwaliteit van leven. Peter, die slechthorend en slechtziend is, gaat langzaam achteruit en wordt bedlegerig. Van Janny wordt verwacht dat zij de palliatieve zorg voor Peter vorm gaat geven.

Petra en Janny zijn allebei verpleegkundige, maar werkzaam in verschillende verpleegkundige werkvelden. Beiden krijgen ze te maken met het verplegen van palliatieve patiënten; Petra heeft daar de nodige ervaring mee. Voor Janny is palliatieve zorg geen vanzelfsprekend onderdeel van haar werk.

Patiënten en hun naasten: palliatieve zorg richt zich ook op naasten. De ondersteuning van naasten tijdens de laatste fase van de ziekte van hun geliefde en de periode hierna (rouw) zijn kenmerkend voor palliatieve zorg.

4. Optimale symptoombestrijding: de patiënt zal niet meer genezen van zijn aandoening, maar dat wil niet zeggen dat er niets meer voor hem of haar gedaan kan worden. Aan de klachten en symptomen van de ziekte en de behandeling kan vaak wel iets gedaan worden. Er zijn richtlijnen ontwikkeld voor de bestrijding van veelvoorkomende symptomen, zoals pijn, benauwdheid, vermoeidheid, obstipatie, angst en delier (www.pallialine.nl).

5 Kwaliteit van leven: het doel van palliatieve zorg is niet het leven te verlengen of te verkorten, maar om een zo hoog mogelijke kwaliteit van leven te bereiken voor de ernstig zieke patiënt. Onnodig belastende behandelingen en onderzoeken kunnen vermeden worden wanneer kwaliteit van leven uitgangspunt is in zorg.

In de initiële opleiding tot verpleegkundige horen deze specifieke kenmerken een plek te hebben. Een deel van de bijbehorende competenties, bijvoorbeeld multidisciplinair samenwerken, heeft in de beroepsopleiding al een vaste plek. Met een verbijzondering van de bestaande lesstof kunnen basale kennis, kunde en 
vaardigheden voor het verplegen van patiënten in de palliatieve fase ontwikkeld worden. Voor meer specifieke competenties, bijvoorbeeld rondom symptoombestrijding, moet meer gerichte lesstof aangeboden worden. Onderzoek heeft laten zien dat veel initiële opleidingen tot verpleegkundige of verzorgende nog onvoldoende aandacht bieden aan palliatieve zorg. ${ }^{6}$ In Nederland bestaat een groot aanbod van korte vervolgopleidingen voor verpleegkundigen en verzorgenden waar veel animo voor is, om dit hiaat op te lossen. Daarnaast zijn er enkele uitgebreide, specialistische vervolgopleidingen ontwikkeld voor de echte experts op het gebied van de palliatieve verpleegkunde.

\section{Box 2 Opleiding in de palliatieve zorg}

Helma is na haar afstuderen als verpleegkundige een aantal jaren werkzaam geweest op de oncologische afdeling van een ziekenhuis. Daar werd zij zo geboeid door de zorg voor ongeneeslijk zieke patiënten dat zij zich verder heeft gespecialiseerd in de palliatieve zorg. Sinds enkele jaren is zij werkzaam in een hospice. $\mathrm{Na}$ een basiscursus palliatieve zorg voor verpleegkundigen, waarin een eerste inhoudelijke verdieping in de palliatieve zorg werd gegeven (symptoombestrijding, spiritualiteit en psychosociale ondersteuning), heeft ze een gespecialiseerde opleiding in de palliatieve zorg gevolgd om deskundig te worden in het zorg verlenen in complexe palliatieve situaties en om vaardigheden te ontwikkelen op overstijgend gebied, zoals het verlenen van intercollegiale consulten, participeren in netwerken en verzorgen van trainingen. In het hospice werkt zij nauw samen met de hospicearts, de geestelijk verzorger en de vrijwilligers van het team. Ze heeft inmiddels een ruime ervaring in de palliatieve zorg, ook in complexe situaties, en is sinds enige tijd ook werkzaam binnen de consultatievoorziening in haar regio.

In de korte casussen van Janny, Petra en Helma (zie boxen 1 en 2) zijn verschillende niveaus van deskundigheid voor het verplegen van palliatieve patiënten beschreven. Niet iedere verpleegkundige heeft evenveel ervaring en kennis op dit gebied. In Nederland wordt een aantal deskundigheidsniveaus omschreven.

* Deskundigheidsniveau $A$ betreft het niveau van deskundigheid van initieel opgeleide verpleegkundigen. $\mathrm{Zij}$ zijn deskundig in het verlenen van palliatieve zorg in meer algemene zorgsettingen en laagcomplexe zorgsituaties. Verpleegkundige Janny is deskundig op niveau A.

w Deskundigheidsniveau $B$ betreft het niveau van deskundigheid van gevorderde verpleegkundigen met ruime ervaring op het gebied van palliatieve zorg, waaronder ook in complexe zorgsituaties. Verpleegkundigen op dit gebied hebben een aanvullende opleiding op het gebied van de palliatieve zorg gevolgd 
(verpleegkundige Petra). Een deel van de verpleegkundigen op het B-niveau heeft daarnaast aanvullende competenties op het gebied van consultatie (onder andere gestructureerd doorvragen, coachen en adviseren van collega's) en zijn werkzaam in regionale (en soms intramurale) consultatieteams waar professionals met patiëntgebonden vragen advies en ondersteuning kunnen krijgen in complexe palliatieve zorgsituaties. Dit is het geval bij Janny die door collega's, die te maken hebben met ingewikkelde zorgsituaties, kan worden geconsulteerd.

= Deskundigheidsniveau $C$ betreft het niveau van deskundigheid van academisch opgeleide verpleegkundigen met aanvullende competenties op het gebied van onderwijs en onderzoek over palliatieve zorg.

Hierna zal in aansluiting bij de eerder genoemde kenmerken van palliatieve zorg (zie de definitie en uitgangspunten van de WHO in paragraaf 1.1.1) een voorbeeld van een competentiebeschrijving worden gegeven.

\subsubsection{Integrale zorg}

De integrale benadering omvat naast aandacht en zorg voor fysieke klachten en symptomen ook de zorg voor het emotionele, sociale en spirituele welzijn van de palliatieve patiënt. Dit betekent onder andere dat verpleegkundigen over de juiste communicatietechnieken en gespreksvaardigheden moeten beschikken, op de hoogte moeten zijn van voorkomende symptomen in de palliatieve fase, moeten kunnen werken met gevalideerde meetinstrumenten zoals de Delirium Observatieschaal (DOS), Pijnanamnese en NRS-meting of Hospital Anxiety Depression Scale (HADS). Voorbeelden van competenties met betrekking tot integrale zorg zijn.

* De verpleegkundige beheerst communicatietechnieken en past deze toe in haar begeleiding van de patiënt en diens naasten of nabestaanden (deskundigheidsniveau $A, B$ en $C$ ).

" De verpleegkundige heeft kennis van en respect voor individuele, cultuur- en religiegebonden wensen, gebruiken, voorschriften en rituelen rondom het sterven, de zorg voor het overleden lichaam en het omgaan met verdriet en rouw. De verpleegkundige begeleidt de patiënt en diens naasten door onder andere het bewaken van de uitvoering van deze wensen, gebruiken, voorschriften en rituelen en het desgewenst verwijzen naar relevante dienst- en zorgverleners (deskundigheidsniveau A, B en C).

w De verpleegkundige begeleidt de patiënt en diens naasten bij het omgaan met de sociale gevolgen en veranderingen in de palliatieve fase. Zij heeft daarbij aandacht voor onder andere rolverandering, familieverhoudingen, rouwprocessen, copingmechanismen, evenals financiële en juridische problemen en vragen (deskundigheidsniveau $\mathrm{B}$ en $\mathrm{C}$ ). 


\subsubsection{Multidisciplinair werken}

Van alle betrokken disciplines wordt verwacht dat zij een gezamenlijk beleid uitvoeren en samenwerken in de zorg voor een palliatieve patiënt. Dit betekent dat verpleegkundigen competenties moeten bezitten om met andere disciplines samen te werken, zorg te coördineren en continuïteit te bewaken. Daarnaast moet de verpleegkundige goed inzicht hebben in haar eigen professionele mogelijkheden en beperkingen. Enkele voorbeelden van competenties met betrekking tot interdisciplinair werken door verpleegkundigen in de palliatieve fase zijn.

- De verpleegkundige onderhoudt contacten met andere disciplines ten behoeve van de uniformiteit, continuitteit, doelmatigheid en coördinatie van de (totale) te geven zorg in de palliatieve fase om kwaliteit van zorg te waarborgen (deskundigheidsniveau A, B en C).

= De verpleegkundige bewaakt haar eigen positie en grenzen in zowel professionele als emotionele zin (deskundigheidsniveau A, B en C).

= De verpleegkundige adviseert de patiënt en diens naasten en de behandelend arts en andere betrokken zorgverleners over mensen en middelen die aangewend moeten worden om de zorg in de palliatieve fase te realiseren. Zij let op de wensen, behoeften, mogelijkheden en beperkingen van de patiënt en diens naasten. Zij houdt rekening met de beschikbaarheid en bereikbaarheid van zorgverleners en zorgvoorzieningen. De verpleegkundige betrekt in haar advies de actuele en de in de toekomst te verwachten situatie van de patiënt en diens naasten (deskundigheidsniveau B en C).

\subsubsection{Patiënten en hun naasten}

In de palliatieve zorg wordt de naaste (partner, kinderen of andere intensief betrokkenen) eveneens als zorgvrager beschouwd. Voor de ondersteuning en begeleiding van naasten zijn specifieke competenties te benoemen. Enkele voorbeelden hiervan zijn.

* De verpleegkundige verzorgt de eerste opvang van de naasten van de patiënt en de begeleiding bij verdriet en rouw. De verpleegkundige handelt tijdens en na het overlijden van de patiënt in overeenstemming met de individuele wensen en de culturele en religieuze voorschriften en gebruiken van de patiënt en diens naasten (deskundigheidsniveau $A, B$ en $C$ ).

in De verpleegkundige stimuleert en ondersteunt de zorgverlening vanuit het sociale netwerk van de patiënt en vult deze mantelzorg of vrijwilligerszorg waar nodig en in overleg aan (deskundigheidsniveau A, B en C).

- De verpleegkundige geeft voorlichting aan de patiënt en diens naasten, en desgewenst aan mantelzorgers en vrijwilligers, over de mogelijke problemen die in de specifieke situatie van de patiënt in de toekomst kunnen optreden. De verpleegkundige informeert de patiënt en diens naasten over hun positie en rol bij de besluitvorming in de palliatieve fase in het algemeen en aan het eind van het leven in het bijzonder (deskundigheidsniveau B en C). 


\subsubsection{Optimale symptoombestrijding}

Optimale symptoombestrijding is een voorwaarde voor goede palliatieve zorg. Voor een groot aantal symptomen zijn landelijke richtlijnen beschikbaar die regelmatig worden herzien. Niet alleen veelvoorkomende, maar ook juist zeldzame symptomen worden beschreven zodat voor iedere zorgverlener, relevante en actuele informatie voorhanden is. ${ }^{5}$ Een aantal verpleegkundige competenties op het gebied van de symptoombestrijding zijn.

- De verpleegkundige maakt gebruik van hulpmiddelen, materialen en apparatuur die ingezet worden in de palliatieve zorg. Zij gebruikt bijvoorbeeld infusieapparatuur voor toediening van medicatie, materialen voor de behandeling van wonden en decubitus, en hulpmiddelen ten behoeve van een meer comfortabele transfer en wisselligging (deskundigheidsniveau A, B en C).

- De verpleegkundige is bekwaam in het in kaart brengen van pijn en andere symptomen van de patiënt in de palliatieve fase. De verpleegkundige observeert en rapporteert de werking en bijwerkingen van medicatie en andere interventies (deskundigheidsniveau A, B en C).

- De verpleegkundige verleent palliatieve consulten op het gebied van:

- symptoombehandeling;

- problemen op het gebied van lichamelijke, psychosociale en spirituele aspecten van palliatieve zorg;

- coördinatie en organisatie van palliatieve zorg, inclusief verwijzing naar andere voorzieningen en andere zorgverleners;

- interdisciplinaire samenwerking en ondersteuning inclusief vormen van intervisie (deskundigheidsniveau B en C).

\subsubsection{Kwaliteit van leven}

Kwaliteit van leven is een individueel begrip dat door ieder mens anders wordt ingevuld. Als verpleegkundige moet je je bewust zijn van je eigen ideeën over wat een goede kwaliteit van leven is en wat je al dan niet acceptabel vindt als het gaat om onderzoek en behandeling en beslissingen rondom het levenseinde. Je eigen normen en waarden hierover kunnen afwijken van wat de patiënt en zijn naasten of andere zorgverleners als kwaliteit van leven beschouwen. De volgende competenties gaan in op deze, vaak ethische kwesties die kunnen spelen in de verpleegkundige zorg aan palliatieve patiënten.

" De verpleegkundige evalueert de effecten van de uitvoering van het zorgplan op het welbevinden en de draagkracht van de naasten en mantelzorgers. $\mathrm{Zij}_{\mathrm{ij}}$ rapporteert de uitkomsten van de evaluatie in het zorgdossier en naar andere betrokken zorgverleners en stelt het zorgplan bij (deskundigheidsniveau A, $\mathrm{B}$ en $\mathrm{C}$ ).

II De verpleegkundige reflecteert op haar eigen visie op en waarden van het leven, het einde van het leven en de dood (deskundigheidsniveau A, B en C). 
w De verpleegkundige heeft kennis en inzicht in, en bewaakt haar grenzen in het omgaan met ethische richtlijnen in ethische dilemma's en besluitvorming in de palliatieve zorg (deskundigheidsniveau $\mathrm{B}$ en $\mathrm{C}$ ).

\subsubsection{Onderwijs aan verpleegkundigen}

In de initiële beroepsopleiding tot verpleegkundige komen leerling-verpleegkundigen voor het eerst in aanraking met professionele palliatieve zorg. In het onderwijs zal worden ingegaan op de theoretische achtergronden en kennis over palliatieve zorg. Daarnaast zullen de meeste verpleegkundigen in opleiding te maken krijgen met het overlijden van patiënten op de afdelingen en units waar ze werkervaring opdoen. Het is wenselijk dat naast theoretische kennis uit boeken ook praktische ervaring wordt opgedaan met het verplegen van palliatieve patiënten. Inzicht in wat goed gaat, lastig is en wat eigen emoties en ideeën zijn als het gaat om (de zorg aan) ernstig zieke patiënten en hun overlijden, zijn niet in de klas te leren en daarbij van groot belang voor de ontwikkeling tot professioneel beroepsbeoefenaar.

In Nederland is weinig onderzoek gedaan naar de wensen en behoeften van verpleegkundigen als het gaat om deskundigheidsbevordering op het gebied van palliatieve zorg. Onderzoek van Adriaansen laat zien dat de meeste hbo-opleidingen verpleegkunde in hun curriculum nog te weinig aandacht besteden aan palliatieve zorg. ${ }^{6}$ Wel is er een grote hoeveelheid vervolgopleidingen ontwikkeld voor verpleegkundigen en verzorgenden. Dit lijkt een antwoord te zijn op de vele vragen van deze beroepsbeoefenaren naar meer kennis en kunde op dit gebied. De kwaliteit van deze vervolgopleidingen wordt in toenemende mate beoordeeld door de beroepsvereniging Verpleging en Verzorging Nederland (V\&VN). In het kwaliteitsregister V\&V kunnen opleidingen zich aanmelden en accreditatie vragen in het deskundigheidsgebied palliatieve verpleegkunde. Een onafhankelijke commissie beoordeelt het curriculum, de werkwijze (onder andere de combinatie praktijk/theorie en de docenten) en de kwaliteit van de geboden opleiding en neemt, bij een positieve beoordeling, de opleiding op in het deskundigheidsgebied palliatieve verpleegkunde. Hiermee komt meer duidelijkheid over de kwaliteit van het enorme aanbod van vervolgopleidingen op het gebied van de palliatieve zorg.

Belangrijk is wel te realiseren dat alleen het volgen van een opleiding de dagelijkse zorgverlening niet verandert. Literatuur over dit onderwerp beschrijft een kloof tussen theorie en praktijk en hoe lastig het is nieuwe kennis en kunde te integreren in het dagelijks werk. Daarbij is het automatisch vertalen van 'problemen op de werkvloer' in 'behoefte aan scholing' een valkuil. Wanneer de zorg voor patiënten in de palliatieve fase niet naar wens verloopt, dan is het zinvol om eerst na te gaan waar dit door veroorzaakt wordt. Problemen in de samenwerking met andere collega's, te weinig praktische randvoorwaarden om palliatieve zorg te verlenen of onduidelijkheden over wat welke discipline nu doet, zijn problemen in de samenwerkings- en 
organisatorische sfeer die een ander antwoord vragen dan deskundigheidsbevordering van de verpleegkundige.

Daarnaast is deskundigheidsbevordering meer dan scholing alleen. Er zijn veel andere (en soms zelfs zinvollere) manieren om je als verpleegkundige te bekwamen in palliatieve zorg. Te denken valt dan aan het bezoeken van symposia of congressen, deelnemen of zelf initiëren van verbeterprojecten op de werkvloer, bijdragen aan casuïstiekbesprekingen, het volgen of (beter nog) het zelf verzorgen van klinische lessen en het consulteren van collega's, bijvoorbeeld via de regionale consultatievoorzieningen.

Voor verzorgenden geldt in grote lijnen hetzelfde als voor verpleegkundigen: de initiële opleiding tot verzorgende biedt lang niet altijd voldoende inhoud als het gaat over palliatieve zorg, en de vraag van verzorgenden om vervolgopleidingen op dit gebied is groot. Ook voor verzorgenden worden in toenemende mate cursussen en vervolgscholingen ontwikkeld waarvan de kwaliteit niet helder is. Een ontwikkeling richting accreditatie van opleidingen voor verzorgenden is wenselijk.

\subsubsection{Conclusie}

Het overzicht van de competenties van verpleegkundigen wordt in Nederland de komende tijd ingedikt en beschreven volgens de CanMeds-methodiek.7 Dit is een internationaal aanvaarde methode om specifieke competenties van beroepsbeoefenaren in de gezondheidszorg te beschrijven. Hierdoor wordt het competentieoverzicht in de praktijk hanteerbaarder voor opleiders, managers en verpleegkundigen, kan er beter gecommuniceerd worden met andere disciplines in de palliatieve zorg en met palliatief verpleegkundigen in het buitenland.

\section{LITERATUUR}

I Nederlandse Vereniging voor Verpleegkundigen werkzaam in de Palliatieve Zorg. Beroepsdeelprofiel Verpleegkundige werkzaam in de palliatieve zorg. AVVV, Utrecht, 2004. http://palliatieveverpleegkunde.venvn.nl/Portals/53/publicaties/beroepsdeelprofiel\%202004.pdf.

2 European Association for Palliative Care. A Guide for the Development of Palliative Nurse Education In Europe. EAPC, Milaan, 2004. www.eapcnet.org/download/forTaskforces/NurseEducationGuide.pdf.

3 V\&VN Palliatieve Verpleegkunde. Kwaliteitskader voor het opleiden van verpleegkundigen in de palliatieve zorg in Nederland. V\&VN, Utrecht, 2008. http://palliatieveverpleegkunde.venvn.nl/ Portals/53/publicaties/Kwaliteitskader-verpleegkundigen-PZ.pdf.

4 www.who.int/cancer/palliative/definition.

5 Graeff, A. de, J.M.P. van Bommel, R.H.P.D. van Deijck, et al. Richtlijnen palliatieve zorg. VIKC, Utrecht, 2010. www.pallialine.nl.

6 Adriaansen, M.J.M. Nursing education in palliative care: content, effects and implementation. Proefschrift. Radboud Universiteit, Nijmegen, 2007. http://dare.ubn.kun.nl/ bitstream/2066/30922/1/30922_nursedinp.pdf.

7 V\&VN Palliatieve Verpleegkunde. CanMeds Verpleegkundigen in de palliatieve zorg. V\&VN, Utrecht, 2011. 
DE ACtOREN IN HET VELD VAN DE PALLIATIEVE ZORG 85

\subsection{SAMENWERKING VAN VERPLEEGKUNDIGEN EN ARTSEN}

\section{Saskia Teunissen}

Patiënten die in de palliatieve fase van een levensbedreigende ziekte terechtkomen, hebben vrijwel altijd al een relatie met hun huisarts en meestal ook met één of meer medisch specialisten. De relatie met verpleegkundigen is tot aan de markering van de palliatieve fase vaak beperkt. Er is sprake van bijvoorbeeld incidentele contacten met een gespecialiseerd verpleegkundige van een thuiszorgorganisatie vanwege begeleidingsgesprekken (advies, instructie en voorlichting) en/of met de ziekenhuisverpleegkundige(n) rondom behandeling. Pas wanneer de patiënt in de palliatieve fase meer ondersteunende zorg (functioneel/instrumenteel, somatisch, psychosociaal, spiritueel) nodig heeft, komen verpleegkundigen meer in beeld. Als verpleegkundige stap je dan op de trein waarin de patiënt en zijn naasten al enige tijd begeleid en behandeld worden door huisarts en specialisten. Je komt dus als vanzelfsprekend in aanraking met deze relaties van de patiënt (wanneer hier gesproken wordt over de patiënt worden ook zijn naasten bedoeld).

Deze paragraaf gaat in op de samenwerking tussen verpleegkundigen enerzijds, en huisartsen en medisch specialisten anderzijds. Aandacht gaat daarbij vooral uit naar de overlap en de grensvlakken van het verpleegkundig domein en het medisch domein. Verpleegkundigen zijn in de zorg voor mensen in de palliatieve fase van ziekte misschien wel het minst afhankelijk van de medische discipline in vergelijking met andere stadia van ziekte en behandeling. Palliatieve zorg wordt door het grootste deel van de artsen voornamelijk gezien als een zorgdomein en daarmee wordt veel verantwoordelijkheid aan verpleegkundigen overgelaten.

Er zijn echter een paar kanttekeningen te maken bij deze constatering:

w verpleegkundigen beschikken niet altijd over de kennis, vaardigheden en tijd om te doen wat nodig is in de zorg voor de patiënt en naasten;

m verpleegkundigen hebben geen beslissingsbevoegdheid bij beslissingen rondom het levenseinde;

- verpleegkundigen willen, evenals door de palliatieve zorg bezielde artsen, graag in teamverband werken;

w de wijze van samenwerking wordt sterk bepaald door enerzijds het stadium van de palliatieve fase en anderzijds ook door de locatie waar de patiënt verblijft en zorg krijgt.

In de praktijk van alledag is het de uitdaging de beste zorg te geven in de best mogelijke samenwerking. In deze paragraaf gaan we verder in op veelvoorkomende dilemma's en worden adviezen gegeven die de samenwerking kunnen ondersteunen. 


\subsubsection{Onvoldoende kennis, vaardigheden en tijd}

De samenwerking met huisarts en/of medisch specialist wordt voor een belangrijk deel bepaald door de kennis en vaardigheden waarover je als verpleegkundige beschikt. De heterogeniteit van onze beroepsgroep maakt het voor artsen lastig in te schatten wat we wel of niet kunnen. De differentiatie van onze functies en de grote mate waarin we parttime werken maakt het voor artsen vaak lastig te bepalen wie nu welke verantwoordelijkheid draagt/kan dragen. Het is zowel een organisatorische als een individuele opdracht om aan artsen met wie wordt samengewerkt, glashelder aan te geven wat er wel of niet van ons verwacht kan worden in de samenwerking. We zijn als beroepsgroep, met onze leidinggevenden, zelf verantwoordelijk voor het ontwikkelen van passende kennis en vaardigheden en daaruit volgend het zichtbaar maken van de eigen grenzen.

Er zijn allerlei ondersteunende documenten, en best of good practices (goede voorbeelden) waarvan gebruikgemaakt kan worden, zoals (in Nederland) het beroepsdeelprofiel palliatieve zorg van V\&VN Palliatieve Verpleegkunde en de Landelijke Eerstelijns Samenwerkingsafspraken (LESA) Palliatieve Zorg., ${ }^{1,2}$ Voor het verder ontwikkelen van kennis en vaardigheden is het goed gebruik te maken van de competenties (voor verschillende functieniveaus) zoals vastgelegd in het Kwaliteitskader voor het opleiden van verpleegkundigen in de palliatieve zorg in Nederland. ${ }^{3}$ Voor directe toepassing in de praktijk kan gebruikgemaakt worden van specifiek voor de palliatieve zorg ontwikkelde methoden en technieken. Daarbij kan gedacht worden aan bijvoorbeeld de methode van palliatief redeneren als aanvulling op het traditioneel klinisch redeneren ${ }^{4}$ maar ook aan de inzet van meetinstrumenten om symptomen en de totaal ervaren symptoomlast te meten zoals de door het Nederlandse Nationaal Programma Kankerbestrijding aanbevolen lastmeter. ${ }^{5}$ Het gebruik van dergelijke 'goede voorbeelden' of best practices levert twee voordelen op: gegevens over en rondom de patiënt worden zo veel mogelijk geobjectiveerd en er wordt gesproken in een heldere gemeenschappelijke taal die evenzo belangrijk is. Verpleegkundigen die, geheel conform hun eigen beroepsgroep, spreken over verpleegkundige diagnosen geordend volgens de elf gezondheidspatronen van Marjory Gordon, ${ }^{6}$ zijn voor artsen over het algemeen onverstaanbaar. De diagnose ineffectieve ademhaling is voor de gemiddelde huisarts/specialist toch lastiger in een gesprek op te pakken dan de internationaal herkenbare symptoombenaming dyspnoe. Verpleegkundigen helpen zichzelf en elkaar door eenvoudig rekening te houden met het risico van verschillen en de winst van overeenkomsten in de samenwerking en met name wanneer het kritische beslismomenten betreft.

Tijd is een ander kritisch aspect in de samenwerking. Verpleegkundigen hebben vaak andere werktijden dan artsen, waardoor er hoge eisen gesteld worden aan de planning en invulling van bijvoorbeeld kritische gesprekken naar aanleiding van slecht nieuws of bijstelling van beleid. De druk op de tijd van beide beroepsgroepen 
neemt toe. Toch is het voor goede samenwerking nodig dat verpleegkundigen zich daarin waar mogelijk aanpassen en zorg dragen voor afstemming en continuïteit naar zowel arts als patiënt. Uitspraken in de zin van 'dat weet ik niet, want ik kom net terug van vrije dagen' of 'dat moet mijn collega zo meteen dan maar overnemen, want ik ga zo naar huis, ik ben al vanaf zeven uur in touw' moeten we elkaar verbieden. Binnen organisaties is het zinvol na te gaan of een minder traditionele invulling van werktijden mogelijk is om de samenwerking te verbeteren en daarmee de zorg meer kwaliteit te geven.

\subsubsection{Geen beslissingsbevoegdheid bij beslissingen rondom het levenseinde}

Wanneer het aankomt op beslissingen rondom het levenseinde, zoals het staken van levensverlengende handelingen, het al dan niet reanimeren, het starten van palliatieve sedatie of het overgaan tot euthanasie, hebben verpleegkundigen wel een rol maar geen bevoegdheid in de besluitvorming (zie ook paragraaf 1.4). Veel organisaties waar verpleegkundigen werken hebben in protocollen of werkafspraken vastgelegd wat de procedures zijn rondom dergelijke beslissingen. In de praktijk volstaan ze toch niet altijd omdat de procedures voorbijgaan aan de emotie die hand in hand gaat met het proces van besluitvorming. Daar waar de verpleegkundige haar rol als informatieverstrekker aan de arts (huisarts of medisch specialist) heel serieus neemt en er vaak gestreefd wordt naar een consensusadvies van een verpleegkundig team aan de arts, is het de arts die - vaak onafhankelijk van dat advies - louter en alleen in afstemming met patiënt en naasten de beslissing neemt. De emotionele belasting voor de arts is vaak groter dan verpleegkundigen zich realiseren vanwege hun focus op de eigen rol. Dit kan leiden tot het gevoelsmatig frustreren van een samenwerking die tot aan het betreffende kritische beslismoment heel voorspoedig verliep.

Ervaring leert dat zowel huisartsen als medisch specialisten zich bij herhaling in diverse settings van zorg uitspreken in de zin van: 'Alsof ik me moet verantwoorden naar het verpleegkundig team ... ik moet me alleen maar verantwoorden naar de patiënt, mezelf en mijn beroepsgroep ... alsof dat al niet genoeg is.' Zorgvuldigheidseisen bewaken is geen verantwoordelijkheid van verpleegkundigen. Een verpleegkundige dient in dergelijke situaties voldoende zelfkritisch te zijn en vooral verantwoordelijkheid te nemen binnen het eigen domein: het geven van optimale palliatieve zorg. Vanuit dat streven kunnen wel vragen gesteld worden rondom een levenseindebeslissing, namelijk: Hebben we alles gezien en gedaan wat in ons vermogen van de meest optimale palliatie ligt? Hebben we extra expertise ingeschakeld waar we tegen onze eigen grenzen aanliepen? Wanneer verpleegkundigen dergelijke vragen stellen en reflecteren op de feitelijke situatie van de patiënt met scherpe observaties van zijn lijden en gedrag, dan leveren zij in dergelijke situaties een cruciale bijdrage. Het zijn dus professionele bijdragen in denken, doen en laten die het cement van samenwerking vormen. 


\subsubsection{In teamverband willen werken}

Iedereen die bezield is door palliatieve zorg, ongeacht zijn of haar discipline, ziet het belang van multidimensionaliteit en interdisciplinariteit in de zorg voor mensen in de palliatieve fase. In sommige werksituaties is samenwerken als een team gemakkelijker en vanzelfsprekender dan in andere situaties. De kunst is om als verpleegkundige gebruik te maken van de overlegvormen en van de communicatie- en coördinatiemiddelen die er binnen de organisatie zijn, om uit te komen op de best haalbare samenwerking. Het aanspreken op en waarderen van elkaars complementaire verantwoordelijkheden en vaardigheden ondersteunen over het algemeen meer de samenwerking dan het druk zetten op een verplicht samenwerkingsmodel. In samenwerking gaat het immers ook gewoon om het feit of je elkaar ligt of niet. $\mathrm{Er}$ zijn steeds meer goede voorbeelden van samenwerkingsafspraken binnen de palliatieve zorg. De eerder genoemde LESA Palliatieve Zorg geeft goede handvatten voor ontwikkeling van de samenwerking, ook in de intramurale zorg. Verpleegkundigen en huisarts en/of medisch specialist hebben hierin een vergelijkbare verantwoordelijkheid, namelijk het leveren van een passende bijdrage vanuit de eigen deskundigheid. Het is vanuit dat oogpunt niet wenselijk de (huis)arts voorzitter te maken van het samenwerkingsteam omdat daarmee de valkuil van dominantie door de arts wordt gecreëerd. Verpleegkundigen kunnen een beroep doen op hun organisatie om het procesmatige voorzitterschap van een samenwerkingsteam te faciliteren.

\subsubsection{Stadium en de locatie van zorg}

Vroeg in de palliatieve fase, ook wel de fase van ziektepalliatie genoemd, pendelen patiënten en hun naasten vaak frequent heen en weer tussen diverse locaties van zorg. De nadruk van zorg en behandeling ligt daarbij vaak in het ziekenhuis (bijvoorbeeld in geval van palliatieve chemotherapie bij kanker), terwijl er thuis nog nauwelijks zorg nodig is. In die periode werken ziekenhuisarts en ziekenhuisverpleegkundigen samen volgens de protocollen van de betreffende afdeling en organisatie. Vaak is de multidisciplinaire bespreking een wekelijks moment voor het uitwisselen van kennis en problemen en is de wijze van samenwerking besloten in de cultuur van de unit of afdeling. De verpleegkundige zal vaak technisch faciliterend zijn voor de behandelaar en daarnaast inbrengen wat haar op functioneel en/of psychosociaal gebied opvalt.

Wanneer de ziekte voortschrijdt, wordt er door de behandelaars een toenemend beroep gedaan op ondersteunende disciplines, waaronder verpleegkundigen. De kunst voor verpleegkundigen is dan om op de eerder genoemde rijdende trein te stappen met enerzijds een open blik en anderzijds een bereidheid tot aanpassing aan de situatie die er is. Het is de verantwoordelijkheid van de arts om verpleegkundigen van optimale informatie te voorzien om de zorg in te zetten, het is de verantwoordelijkheid van verpleegkundigen om de goede vragen te stellen. In de praktijk is contact 
tussen de hoofdbehandelaar en verpleegkundigen echter vaak een illusie. In het ziekenhuis heeft de verpleegkundige veelal te maken met een zaalarts die de patiënt en zijn voorgeschiedenis niet altijd goed kent en in de thuiszorg hebben verpleegkundigen te maken met de afgegeven indicatie en de informatie die daaruit voortkomt. Verpleegkundigen in de eerste lijn hebben soms patiënten van wel vijftien verschillende huisartsen, waardoor de mogelijkheid om direct te communiceren bemoeilijkt wordt. Daarentegen wordt in de zorg thuis zodra de indicatie terminale zorg afgegeven is, vaak gewerkt met een gezamenlijk zorgplan en zorgdossier, in tegenstelling tot in het ziekenhuis waar artsen en verpleegkundigen vrijwel altijd een volledig eigen dossier blijven voeren. Een belangrijke ontwikkeling in de samenwerking in de terminale fase is ingezet door de introductie van het Engelse model 'Zorgpad Stervensfase'.7 Dit is een standaard voor terminale zorg waarin de samenwerking tussen artsen en verpleegkundigen, ongeacht de locatie van de zorg, zorgvuldig is beschreven in taken en verantwoordelijkheden. Opmerkelijk punt daarin is de start van een gezamenlijk dossier op het moment dat wordt vastgelegd dat de stervensfase ingaat (inschatting maximaal 72 uur voor overlijden).

\subsubsection{Wat kunnen de patiënten in de samenwerking van verpleegkundigen verwachten?}

Wat patiënten in de palliatieve fase precies van verpleegkundigen verwachten, is niet voor alle patiëntengroepen of diagnosegroepen eenduidig te formuleren, mede omdat het onderzoek daarnaar nog beperkt is. Er zijn verschillende websites waar uit diverse studies wensen en verwachtingen van patiënten over de palliatieve zorg zijn opgesomd en toegelicht. ${ }^{8}$ Belangrijke punten die ook vragen om goede samenwerking tussen artsen en verpleegkundigen zijn: pijn- en symptoombestrijding, informatie over het ziekteproces, emotionele steun, begeleiding bij beslissingen rondom het levenseinde en zorg voor een veilige omgeving. Wanneer we al deze punten afzonderlijk bekijken, zien we de hierboven beschreven aandachtspunten weer terug. Kennis, vaardigheden, bereidheid, gebruik van beschikbare instrumenten, communicatie, coördinatie en verslaglegging moeten op orde zijn om aan de behoeften van patiënten rondom de samenwerking tussen artsen en verpleegkundigen te kunnen voldoen. Patiëntenverenigingen hebben in hun beleidsstukken overigens nauwelijks een standpunt over de zorg door verpleegkundigen opgenomen. Wel is het zo dat in bijvoorbeeld landelijke richtlijnen vaak is opgenomen dat van verpleegkundigen evenals van artsen verwacht wordt dat er technisch hoogwaardige zorg en basale psychosociale zorg wordt gegeven, wat samen moet komen tot de meest optimale zorg in de situatie van de individuele patiënt.

In een onderzoek waarin mensen met kanker gevraagd werd de meest ideale zorgsituatie te beschrijven, kwam een 'top vijf' van aandachtspunten voor samenwerkende artsen en verpleegkundigen naar voren: veiligheid, betrokken houding, 
heldere communicatie, vertrouwelijkheid in het omgaan met patiëntgegevens en de mogelijkheid zelf mee te beslissen over de behandeling.9 Dezelfde patiënten gaven aan omgevingsfactoren (bijvoorbeeld voorzieningen op de kamer, de kwaliteit van voeding en privacy) minder belangrijk te vinden dan de bovengenoemde menselijke aspecten. Zorgverleners hebben dus ieder voor zich een grote verantwoordelijkheid, maar ook gezamenlijk. De onderlinge samenwerking zal veelal een spiegel zijn van de relatie met de patiënt.

\subsubsection{Conclusie}

In de samenwerking met artsen in welke hoedanigheid dan ook, is het voor verpleegkundigen van belang de eigen deskundigheid zichtbaar te maken, maar dat kan alleen wanneer je er als team (en beroepsgroep) ook zorg voor draagt dat artsen weten wat ze aan verpleegkundigen hebben. Dat wil zeggen dat je je als individuele zorgverlener en als beroepsgroep bewust bent van je sterke en minder ontwikkelde kanten. Deze paragraaf besluit daarom met enkele samenvattende aandachtspunten die de effectiviteit en het plezier van samenwerken zullen vergroten.

\section{Nalaten in samenwerking}

= Mopper niet over of op de eigen organisatie, beroepsgroep en/of collega's.

\# Bevestig niet dat er door het vele onregelmatige en parttime werken gebrek is aan continuïteit en afstemming (zeg dus nooit: 'dat weet ik niet, want ik kom net terug van vrije dagen'; zorg dat je dingen paraat hebt in gesprek met een arts).

\section{Doen in samenwerking}

In Geef betrokken, liefdevolle maar ook professionele zorg.

\# Communiceer in een heldere gemeenschappelijke taal die voor verpleegkundigen en voor de arts begrijpelijk en herkenbaar is en gebruik waar mogelijk objectiveerbare gegevens.

w Draag zelf zorg voor passende kennis en vaardigheden (doe een appèl op leidinggevenden) en daag collega's uit om samen kennis te vergroten.

w Benoem en respecteer duidelijk je eigen grenzen en die van de ander.

w Maak gebruik van documenten van beroepsgroepen of samenwerkingsprojecten die de samenwerking concreet kunnen faciliteren ofwel waarmaken wat we hebben opgeschreven over onze eigen rol.

- Objectiveer zo veel mogelijk de gegevens over de patiënt: gebruik goede voorbeelden zoals de toepassing van meetinstrumenten om klachten beter in kaart te brengen, of een methodiek voor besluitvorming op kritische beslismomenten.

- Maak gezamenlijk gebruik van de experts van een lokaal of regionaal consultatieteam.

- Durf plezier en tevredenheid uit te stralen en uit te spreken. 
Samenwerking in de zorg voor mensen in de palliatieve fase is een net zo grote uitdaging als de daadwerkelijke zorgverlening aan de patiënt: dus de moeite waard om steeds maar weer te zoeken en te streven naar verbetering.

\section{LITERATUUR}

1 V\&VN Palliatieve Verpleegkunde. Beroepsdeelprofiel palliatieve zorg. AVVV, Utrecht, 2004.

2 Eizenga, W.H., M. de Bont, J.A. Vriezen, et al. Landelijke Eerstelijns Samenwerkings Afspraak Palliatieve Zorg. Huisarts en Wetenschap, 2006, 49, 308-312.

3 V\&VN Palliatieve Verpleegkunde. Competenties palliatieve verpleegkunde. V\&VN, Utrecht, 2009. www.palliatieveverpleegkunde.venvn.nl.

4 Hesselmann, G.M. Palliatief redeneren. Pallium, 2010, 11(2), 8-10. www.pallialine.nl.

5 Nationaal Programma Kankerbestrijding. De lastmeter als instrument voor vroegsignalering van multidimensionele problemen. www.lastmeter.nl.

6 Gordon, M. Handleiding verpleegkundig diagnostiek: met alle goedgekeurde diagnostische categorieën van de North American Nursing Diagnosis Association. Elsevier gezondheidszorg, Maarssen, 2008.

7 The Liverpool Care Pathway of Dying; Zorgpad Stervensfase. IKR, Rotterdam, 2009. www.oncoline. nl; www.pallialine.nl.

8 Met de zoektermen 'verwachtingen van patiënten' is bijvoorbeeld informatie te vinden op www. palliatief.nl en www.nivel.nl.

9 Wessels, H., A. de Graeff, K. Wynia, et al. Medical oncology patients' preferences with regard to health care: development of a patient-driven questionnaire. Annals of Oncology, 2009, 20, $1708-1713$. 


\subsection{DE ROL VAN PASTORES}

\section{Marinus van den Berg}

In Vlaanderen en Nederland spreekt men of over pastores of over geestelijk verzorgers. In Nederland heeft men het vooral over geestelijk verzorgers als het gaat om vrouwen en mannen die de functie van geestelijke verzorging hebben in een instelling voor zorg, zoals ziekenhuizen, psychiatrische centra, instellingen voor mensen met een verstandelijke en/of lichamelijke handicap, verpleeg- en verzorgingshuizen, palliatieve centra en hospices, maar ook in het leger of de gevangenis. In het grotendeels katholieke Vlaanderen spreekt men meer van pastor. Een pastor kan een man of een vrouw zijn, een priester of een pastoraal werkende met meestal een benoeming van de zendende kerk. In Nederland werken ook steeds meer vrouwen en mannen vanuit het Humanistisch Verbond, maar ook rabbijnen, imams, pandits en vertegenwoordigers van boeddhisten. Er zijn ook initiatieven (pools) die het mogelijk maken dat er een beroep gedaan wordt op een geestelijk verzorger/pastor voor mensen die thuis sterven of op een plaats waar geen eigen geestelijke verzorging is. Het gaat dan om mensen die om uiteenlopende redenen geen contact hebben met hun eigen kerkelijke gemeente of parochie.

Afwisselend wordt het woord geestelijk verzorger en pastor gebruikt. In deze paragraaf gaat het over de vraag wat hun rol is: Wat doen ze zoal? Ook zal het gaan over de samenwerking met vooral verpleegkundigen, verzorgenden en artsen. Die samenwerking ziet er op verschillende plaatsen anders uit. Deze paragraaf ontkomt niet aan subjectiviteit. De ervaring en de praktijk van de schrijver spelen een centrale rol; dit is een verhalende benadering.

\subsubsection{Ervaringen uit de praktijk}

Mevrouw E. is een 43-jarige moeder. Ze is gehuwd. Ze heeft haar werk enkele jaren geleden tijdelijk stopgezet om er voor de kinderen te kunnen zijn. Haar kinderen bezoeken alle drie nog de basisschool $(7,8$ en 10 jaar). Ze heeft veel steun aan een nicht en de man van haar nicht, met kinderen in dezelfde leeftijd als haar kinderen. $\mathrm{Bij}$ mevrouw E. is drie jaar geleden kanker vastgesteld. De arts in het ziekenhuis heeft haar en haar man moeten meedelen dat ze nog maar enkele weken te leven heeft. Om meerdere redenen kan ze niet thuis blijven. Mevrouw E. is lid van de remonstrantse kerk. Bij het samenstellen van het zorgplan wordt altijd gevraagd naar iemands levensbeschouwing. Haar huwelijk is kerkelijk ingezegend en haar kinderen zijn er gedoopt. Haar predikant is echter met pensioen en niet beschikbaar voor pastorale begeleiding. Hij bezoekt haar eenmaal in het centrum en is bereid een woord te spreken bij haar uitvaart. Zoals bij iedere gast die in ons centrum komt, stel ik mij bij mijn eerste bezoek aan haar voor. Ik tast af of we na het voorstellen 
over kunnen gaan tot een nadere kennismaking en daarna kunnen spreken over de gewenste steun en begeleiding. Er is dus sprake van een 'drietrapsraket'. Ik zie mezelf allereerst als een vreemde. 'Weer een nieuw gezicht,' zeg ik soms. Ik ben een onbekende, vreemde gast aan de deur. Die deur kan ook gesloten blijven.

In het eerste gesprek vertellen verpleging en/of arts ook altijd dat er een geestelijk verzorger beschikbaar is. Die is er voor ieder die dat wil en niet alleen voor kerkzaken, maar meer voor alle levensvragen. Vragen als: Wat betekent het om hier te moeten komen? Wat betekent het te weten dat het levenseinde nadert? Hoe kijkt een gast naar zijn of haar toekomst? Hoe kijkt iemand terug op het geleefde leven? Waar vindt iemand steun in of wat is juist storend, geeft angst, verwardt hem of haar? Allerlei thema's - schuld, schaamte, verzoening of juist onverzoenlijkheid kunnen ter sprake komen. Het kan ook gaan over het kunnen dragen van de pijn. Altijd zijn de levensstijl, de levenswijze en de levensbeschouwing het centrale punt van aandacht. Er is dus geen sprake van missie, bekeringsdrift of opdringend gedrag, maar inlevend luisteren en aanwezig zijn staan centraal. Als ik word uitgenodigd om verder te komen, te gaan zitten, dan kan ik een vertrouwde worden, maar ik blijf ook een vreemde. Ik ben geen familie, geen vriend en zelfs geen goede kennis.

Bij mevrouw E. ben ik welkom en ze nodigt me uit te gaan zitten. Ze vertelt me van haar leven, haar ziektegeschiedenis, haar zorg om haar kinderen en haar man. Ze vertelt dat ze een lijstje van vijfentwintig zaken heeft waaraan ze nog wil werken. Een ervan is met haar meisjes naar een concert van $\mathrm{K}_{3}$ in Ahoy (wat later dankzij de Stichting AmbulanceWens ook gelukt is). Ze vraagt of ik contact met haar broer wil zoeken en ook of ik haar uitvaartdienst wil leiden. Ze vertelt me over wat haar oudste zoon in de auto zei toen ze naar huis gingen uit het ziekenhuis waar ze het slechte nieuws hadden gehoord. Hij vertelde van een weg waar ze met zijn vijven rijden en dat ineens een van hen - zijn moeder - een zijweg inslaat ... Diezelfde dag maak ik ook kennis met haar man en haar kinderen.

Enkele dagen later spreken we over dit gezin in de wekelijkse zorgplanbespreking, waaraan de verpleging, de arts palliatieve zorg, een huisarts in opleiding, de psychologe, de stafverpleegkundige zorg voor zorgenden, een nurse practitioner in opleiding en een arts-onderzoeker deelnemen. Ook ik ben daar altijd bij aanwezig en ik denk dus ook mee over gasten die ik soms bijna niet ken. Dat kan meedenken zijn over bijvoorbeeld ethische vragen. In dit team worden ook afspraken gemaakt over de taakverdeling.

\subsubsection{Aandacht voor jonge kinderen}

De psychologe zal bijzondere aandacht geven aan de echtgenoot en met hem spreken over de kinderen. Ze zal onder meer onderzoeken hoe de kinderen op school en in de thuissituatie worden ondersteund. Ook wordt afgesproken dat ik zal meedenken met de echtgenoot over de plaats en de rol van de kinderen tijdens de uitvaart. Dit denken 
leidt tot het schrijven van een verhaal met de titel: 'Mijn moeder woont in het nog.' Dit verhaal geef $\mathrm{ik}$ aan mevrouw $\mathrm{E}$. Ik lees het haar voor en zij leest het later zelf nog een aantal keren. Er is een verzorgster die bij het verhaal een tekening maakt en een aquarel. De aquarel krijgt een plaats op haar kamer. De tekening wordt gekopieerd zodat de kinderen die kunnen kleuren tijdens de uitvaartdienst. Met mevrouw E. spreek ik over haar wensen wat betreft de uitvaartdienst, zoals de liederen, maar ook over andere zaken die ze nog wil vervullen, zoals het schrijven van een brief aan elk van haar kinderen. Ook aan de verpleging laat ze haar verdriet merken over dit vroege sterven.

Ze uit haar vragen over waarom juist nu en wat ze allemaal nog had willen betekenen voor haar gezin. Het gaat niet alleen over allerlei zaken die geregeld moeten worden, maar ook over de betekenis die dit alles voor haar en haar gezin heeft. In de keuze voor de liederen klinkt haar religieuze levensgeschiedenis door. Door de gesprekken kom ik meer en meer te weten wie ze was, wie ze echt wilde zijn. Ik mag ook delen in de moeilijke perioden die er ook eerder in haar leven waren. Na zorgvuldig wikken en wegen zoek ik via de telefoon contact met haar broer. Ik vertel over de wens van zijn zus, zonder dat ik een oordeel heb en zonder dat ik hem dwing tot een besluit. Ik ken zelden de verschillende kanten van een vaak ingewikkelde familiegeschiedenis. Verzoening kan niet goedkoop. Tien dagen later brengt haar broer een bezoek. Zij is dan in haar laatste dagen en is niet meer in staat mij te vertellen hoe de sfeer tijdens dit bezoek was en wat de betekenis ervan is geweest.

\subsubsection{Afscheidsritueel}

Gedurende haar verblijf heb ik om de drie dagen korter of langer contact met mevrouw E. Zo ook op de dag dat ze steeds meer aan bed gebonden is en de tijd van de palliatieve sedatie dichterbij komt. Samen met haar man, haar kinderen en haar nicht vindt er een kort religieus afscheidsritueel aan het bed plaats. Dat bestaat uit het aansteken van een huispaaskaars, het vormen van een kring, het uitspreken van een gebed, waarin ik woorden zoek voor de verschillende gevoelens en gedachten op dit moment nu de tijd van de laatste groet zo dichtbij komt. We bidden ook het Onze Vader, zoals dat ook zal gebeuren bij haar uitvaart.

Het leiden en vormgeven van afscheidsrituelen voor het sterven behoort ook tot mijn taken. Dat kunnen ook niet-religieuze rituelen zijn. Soms nodig ik na overleg ook enkele verplegenden uit. Soms schrijf ik een speciale tekst. Ook aandacht voor symbolen is van betekenis. De hand vasthouden, met elkaar nog eenmaal een kring vormen is ook een symbool. Het scherpt het besef dat er binnen korte tijd iemand uit deze kring gemist zal worden.

\subsubsection{Een rol bij het waken}

Soms wordt er van mij ook een rol gevraagd in de periode van het waken. Het gaat dan om het stilstaan bij de zin van het waken, maar ook om de moeite die naasten 
met het waken kunnen hebben. Zij stellen vaak de vraag: Hoe lang gaat het nog duren? Of ze zeggen dat vader dit zo nooit heeft gewild. Naasten lijden aan hun onmacht. Ze hebben ook angst dat hun geliefde nodeloos lijdt. Het zien sterven is een emotionele en unieke gebeurtenis. Velen zagen nooit eerder iemand sterven. Aanwezig zijn bij het sterven biedt hen de kans om te zien hoe dat gaat, soms ook om kleine dingen te doen, om bijvoorbeeld met muziek een goede sfeer te scheppen, soms te zingen, maar het kan ook zwaar zijn. Naasten kunnen zich paniekerig voelen. Goede en herhaalde informatie over het lichamelijke proces van sterven is van grote waarde, maar ook moet aandacht gegeven worden aan de betekenis van dit sterven. Naasten kijken terug op de levensgeschiedenis en de ziektegeschiedenis. Ze gaan ook steeds meer beseffen dat ook dit voor hen een tijd van verandering is. Waar de laatst overgebleven ouder sterft, worden de vaak volwassen kinderen nu wees. Er valt een middelpunt weg. Het kan mijn taak zijn woorden te geven aan deze innerlijke ervaringen en te luisteren naar de persoonlijke verhalen en gevoelens die dit oproept. In mijn boek Voor bij het einde staan teksten die geschreven zijn voor deze tijd van waken. ${ }^{1}$ Herkenning en erkenning vinden kan rust brengen. ${ }^{2,3}$

Mevrouw E. is gestorven op het moment dat er juist even niemand was. Dat gebeurt vaak en artsen en verplegenden waarschuwen hier ook van tevoren voor. Misschien kunnen veel mensen uitsluitend alleen sterven. ${ }^{4}$ Sterven is een intiem gebeuren. In de laatste uren wordt er ook voor gezorgd dat de naasten zo veel mogelijk met elkaar kunnen zijn. Zorg- en hulpverleners beoefenen de kunst van het zich ondersteunend terugtrekken. Er kan altijd een beroep gedaan worden op de verpleging, en ze komen ook af en toe informeren en kijken, maar ze zijn meer op afstand zodat de intimiteit van een gezin, een familie meer ruimte en kans krijgt.

\subsubsection{Afscheid tot aan de deur}

Indrukwekkend is het bezoek dat de kinderen, samen met hun vader en haar nicht, komen brengen in de ochtend dat hun moeder is gestorven. De kinderen zien hun moeder zoals ze overleden in bed ligt. De laatste zorg wordt pas gegeven als de familie gekomen is en gevraagd is of en hoe zij daarbij willen helpen of aanwezig willen zijn. Ik zie dat er ook een rouw-educatieve taak weggelegd kan zijn voor de geestelijk verzorger. Alle details luisteren nauw, ook vanaf het moment van sterven totdat iemand het huis of de instelling verlaat. De kinderen van mevrouw E. huilen en zoeken troost bij hun vader en de nicht van hun moeder en worden door hen getroost. Ze hebben ook vragen voor de dokter, de verpleging en voor mij. Vragen of mamma hen nu toch nog kan zien. Er is verdriet, maar de oudste uit ook zijn woede, zijn onmacht.

In de middag van die dag vindt het uitgeleide plaats. Bij de start van dit centrum heb ik meegedacht over de wijze van uitgeleiden. Niet via een achterdeur, maar via de voordeur waardoor de gast en de familie ook zijn binnengekomen. De overledene wordt al of niet met hulp van de familie in een kist gelegd (dus niet in een plastic hoes op een 
brancard). Over de kist wordt een patchworkkleed gelegd. Daarna wordt de overledene buiten de kamer gereden waar de aanwezige medewerkers en vrijwilligers in een kring wachten. Een van de verzorgenden leest een korte tekst voor, die ik voor dit moment heb geschreven (er zijn drie verschillende versies beschikbaar). De tekst staat op een kaartje met een foto en wordt aan de familie meegegeven. Hierna verlaat de overledene via de lift waarin ook plaats is voor de familie de etage en vormen de medewerkers bij de voordeur een kring. Het kleed wordt van de kist genomen en aan de verpleging teruggegeven. De mensen van de uitvaartonderneming geven de naasten een hand. We wachten in stilte tot de uitvaartauto van het terrein is weggereden en niet meer zichtbaar is. Vaak lopen er enkele medewerkers van de uitvaartonderneming voorop en is het vertrek niet gehaast, maar rustig, stapvoets. Het is niet alleen een indrukwekkend moment tussen al het regelen in, maar draagt ook bij aan waardig afscheid nemen. Het hoort ook tot de taak van de geestelijk verzorger om samen met verplegenden en verzorgenden en alle andere medewerkers steeds weer na te denken over waardig afscheid nemen van telkens weer een uniek mens. Om deze reden is er dan ook steeds informeel en formeel contact met de verplegenden en de leidinggevende. Ik zie het ook als taak om mede cultuurdrager te zijn en deel te nemen aan reflectiemomenten waarop het niet alleen over een specifieke gast gaat (zoals in het wekelijkse multidisciplinaire zorgoverleg), maar waar het ook gaat over zaken die betrekking hebben op hoe de gasten worden ontvangen, hoe ze worden bejegend en wat soms moeilijke gebeurtenissen of gedragingen zijn geweest die verlegenheid hebben opgeroepen.

\subsubsection{Conclusie}

Velen weten wel dat ook het leiden van kerkdiensten, bezinningsbijeenkomsten, uit de Bijbel lezen of bidden tot de taak van een geestelijk verzorger hoort. Ook bemiddelen, zodat iemand de geestelijke verzorging krijgt die voor de gast wenselijk is, behoort daartoe. Er voor iedereen zijn, kan ook inhouden dat ervoor gezorgd wordt dat ieder ontvangt wat voor hem of haar geëigend is.

Dit is passend bij de betekenis van de naam van ons palliatief centrum Cadenza. Het is het laatste deel uit een muziekstuk waarin de solist zich nog eenmaal op zijn eigen wijze kan laten horen binnen het raam van het muziekstuk. Het levensverhaal is het muziekstuk en het is onze zorg dat ieder binnen zijn eigen levensverhaal op eigen wijze en stijl kan sterven. ${ }^{5}$

\section{LITERATUUR}

1 Berg, M. van den. Voor bij het einde: waken en afscheid nemen. Kok, Kampen, 2004.

2 Kalckreuth, E. von. Meelopen naar het einde. Kok, Kampen, 2005.

3 Leget, C. Ruimte om te sterven. Lannoo, Tielt, 2003.

4 Polspoel, A. Eenzaam sterven? Communicatie in de palliatieve zorg. Ten Have, Kampen, 2005.

5 Leget, C. Van levenskunst tot stervenskunst, over spiritualiteit in de palliatieve zorg. Lannoo, Tielt, 2008. 


\subsection{DE ROL VAN DE PSYCHOSOCIALE HULPVERLENERS}

\section{Marij Thewissen en Pascalle Voerman}

Verpleegkundigen en verzorgenden worden opgeleid om patiënten en hun naasten te ondersteunen en te begeleiden bij gezondheid en ziekte. Dit is extra belangrijk in de fase van het leven waarbij het overlijden onafwendbaar wordt, waarbij zoveel losgelaten moet worden en de nabije toekomst onzeker of beangstigend is. Samenwerking van verpleegkundigen met gespecialiseerde professionals in het multidisciplinaire team dat deze ondersteuning en begeleiding kan bieden, zal intensiever worden. In deze paragraaf wordt ingegaan op de rol die deze gespecialiseerde psychosociale hulpverleners spelen in de zorg voor de patiënten en hoe de samenwerking met verpleegkundigen en verzorgenden zo optimaal mogelijk kan zijn. Dit is gebaseerd op de praktijk zoals wij die kennen in Cadenza, een regionaal palliatief centrum in Rotterdam, dat plaats biedt aan twintig gasten en als kenniscentrum en leerhuis bijdraagt aan verbreding en verdieping van kennis en kunde op het gebied van palliatieve zorg in Nederland.

\section{Casus}

Mevrouw Van Wychen, 81 jaar, wordt opgenomen. Ze heeft darmkanker en gaat langzaam maar zeker achteruit. Meneer Van Wychen heeft prostaatkanker. Zijn lichamelijke conditie is goed te noemen, maar hij is bang dat de zorg voor zijn vrouw thuis te zwaar voor hem wordt. Het echtpaar is al meer dan zestig jaar getrouwd, het is een traditioneel huwelijk. Mevrouw Van Wychen heeft al snel haar plaats gevonden in Cadenza. Meneer Van Wychen is er iedere dag en blijft regelmatig een nacht slapen. ledereen is tevreden over het verloop van de opname.

$\mathrm{Na}$ drie weken vertelt een verpleegkundige die regelmatig contact heeft met beiden, dat het hem opvalt dat meneer steeds meer gaat praten en mevrouw steeds minder. Hij heeft het idee dat zij ergens mee zit. Later die week komt het bericht dat meneer slecht nieuws heeft gekregen van de uroloog. Zijn conditie is plotseling omgeslagen en er wordt gesproken over een levensverwachting van enkele maanden. De psycholoog gaat langs bij het echtpaar om de betekenis van deze omslag te bespreken.

Het slechte nieuws is hard binnengekomen. Opeens wordt meneer Van W/ychen ook geconfronteerd met zijn levenseinde. Ondanks de innige relatie blijkt dat het echtpaar een aantal zaken niet naar elkaar heeft uitgesproken. Die blijken nu een barrière te zijn in hun contact. In eerste instantie is in het gesprek bijna 
alleen meneer Van Wychen aan het woord, waarbij hij soms over zijn vrouw heen spreekt. De psycholoog ziet dat mevrouw steeds geëmotioneerder wordt en richt zich specifiek tot haar. Mevrouw zegt tegen haar man hoe belangrijk hij voor haar is, hij is haar alles. Meneer reageert aanvankelijk niet op wat zij zegt. Hij vertelt heel geëmotioneerd dat hij zich altijd had voorgesteld dat hij zijn vrouw tot het einde toe zou bijstaan en het is nu opeens onduidelijk of hij die opdracht die hij zichzelf gesteld had, kan vervullen, omdat hij misschien eerder sterft dan zij. Hij zegt: 'Ze heeft alles voor me opgegeven en ik hoop dat ik haar hand kan vasthouden als zij overlijdt.' Het beeld van het huwelijk wordt wat verder ingevuld. Zij hebben elkaar ontmoet in de oorlog, in Polen. Zij heeft haar thuisland en haar familie achtergelaten om met hem te trouwen. De sterke band die zij hebben, is daardoor ontstaan. Mevrouw Van Wychen vertelt dat haar man degene is geweest die haar een toekomst en een goed leven heeft gegeven.

Zij zegt tegen haar man dat hij haar niet in de steek laat door dood te gaan. Ze hebben samen al zoveel meegemaakt. Wat maakt het nu uit wie eerder zal sterven? Dat hebben ze niet in eigen hand. Ze vertelt dat ze juist zo verdrietig is omdat ze zich zorgen maakt over haar man die ze nu niet kan bereiken. Ze heeft het gevoel dat ze uit elkaar drijven, juist nu ze elkaars steun zo nodig hebben. Meneer kan zijn verantwoordelijkheidsgevoel voor haar niet zo snel loslaten, maar het doet hem zichtbaar goed dat zij niet het gevoel heeft dat hij haar in de steek laat. Hij had andere gedachten over hoe haar laatste levensfase zou zijn. Haar visie op hun situatie is een andere, zij zegt: 'Het komt zoals het komt, we gaan uiteindelijk samen.' Dit geeft hem meer 'lucht'. Al kan hij haar hand niet vasthouden als ze sterft, toch blijkt hij haar grote steunpilaar te zijn.

Door het gesprek met de psycholoog begrijpen mevrouw en meneer Van Wychen elkaar weer beter en komen weer nader tot elkaar.

\subsubsection{Kleine transities}

Een transitie leidt tot verwarring en onzekerheid; wat er was is er niet meer en het is nog onduidelijk wat er voor in de plaats komt. Een transitie is een overgang die het normale leven tijdelijk ontwricht en om aanpassing vraagt. ${ }^{1}$ Dit kan een overgang zijn in levensfase, bijvoorbeeld van kleuterschool naar basisschool, of in fysieke of psychische gesteldheid, zoals ziek en afhankelijk worden, of in sociale rol, bijvoorbeeld het ouderschap. Een transitie is een omslag of keerpunt, een tijdelijk proces waarin betekenisvolle veranderingen plaatsvinden.

Naast deze goed gedocumenteerde grote transities zien wij in de palliatieve fase ook 'kleine transities'. Die zijn meer persoonlijk en passen bij juist deze ene patiënt. 
Ze worden door professionals soms niet als zodanig opgemerkt. Bepaalde gebeurtenissen kunnen van grote betekenis zijn voor de patiënt en zijn naasten. De overgang van orale naar subcutaan toegediende medicatie is bijvoorbeeld voor verpleegkundigen en artsen vaak een praktische beslissing. Voor de patiënt en zijn naasten kan het een markering zijn van de volgende definitieve stap in het proces van lichamelijke achteruitgang. Een ander voorbeeld is wanneer een patiënt niet meer onder de douche kan maar op bed gewassen moet worden. Of wanneer verhoudingen binnen een relatie veranderen door de omstandigheden, zoals we hebben gezien in de casus van het echtpaar Van Wychen. Een kenmerk van een transitie is dat het leven en de levensstijl moeten worden herijkt en aangepast.

In dit proces van herijken en aanpassen kunnen fasen worden onderscheiden. ${ }^{2,3}$ Deze fasen worden toegelicht aan de hand van de casus.

m Een transitie begint met een periode van einde, of afscheiding van het oude. Voor meneer Van Wychen was dit het moment dat hij zich realiseerde dat hij wellicht eerder zou sterven dan zijn vrouw.

in Hierop ontstaat desoriëntatie, verwarring door verlies en uiteenvallen van systemen. Meneer Van Wychen was overstuur omdat hij zijn denkbeeld over zijn rol bij het levenseinde van zijn vrouw moest gaan aanpassen. Hij besefte dat hij misschien niet kon voldoen aan de opdracht die hij zichzelf gesteld had.

in Daarna wordt weer een gevoel van controle ervaren wanneer opnieuw betekenis wordt gevonden, een nieuw begin. Dit vond meneer Van Wychen in de nieuwe inzichten die hij kreeg tijdens het gesprek met de psycholoog. Pas toen hij van zijn vrouw hoorde dat zijn bescherming in al die jaren al zo stevig was opgebouwd dat zij daar veiligheid van ervaarde, ook als hij er niet meer zou zijn, kon hij op een andere manier naar de toekomst gaan kijken. Dit gaf hem weer een gevoel van controle en betekenis. Zijn vrouw had van hem nodig dat hij zich nu juist kwetsbaar opstelde en zich door haar liet steunen. Haar steun en haar visie op hun beider leven en einde waren precies wat hij op dat moment nodig had. Mevrouw Van Wychen kreeg weer echt contact met haar man, een gevoel dat ze even kwijt was geraakt en dat haar wanhopig maakte.

Patiënten en hun naasten komen meestal zelf tot een nieuw evenwicht, een gevoel van controle, passend bij de manier waarop ze gewend zijn om te gaan met stressvolle gebeurtenissen in hun leven. Aandacht van de professionals voor veranderingen die 'kleine transities' kunnen inzetten, draagt hier aan bij. Maar in ongewone omstandigheden, zoals het sterven van een geliefde, blijken mensen soms niet toe te kunnen met de manier waarop ze normaliter reageren. Hun gebruikelijke coping schiet tekort, de situatie vraagt iets anders van hen. Dan kan gespecialiseerde psychosociale hulp nodig zijn om een transitie te begeleiden, zoals beschreven in de casus. 


\subsubsection{Psychosociale zorg; gezamenlijke zorg}

Een belangrijk doel van de psychosociale begeleiding in de palliatieve fase is rust rond het bed creëren, zodat de patiënt op een goede manier zijn leven kan afronden met steun van zijn naasten. ${ }^{4}$ Verpleegkundigen en verzorgenden hebben geleerd te luisteren naar wat een patiënt te vertellen heeft, verkennende vragen te stellen, te verduidelijken welke verwachtingen men heeft van een situatie, mee te bewegen in het perspectief van de patiënt. Dit zijn vaardigheden waarmee deze begeleiding en ondersteuning heel goed tot hun recht kunnen komen.

Het kennen van de eigen professionele grenzen is daarnaast onontbeerlijk om bij een bepaalde situatie tijdig gespecialiseerde hulpverleners te betrekken. Het gaat hierbij niet alleen om de grenzen in opleiding, deskundigheid en bevoegdheid. Het gaat ook over grenzen van goed hulpverlenerschap: hoe kunnen we de zorg binnen het team zo goed mogelijk organiseren. In de casus van mevrouw Van Wychen heeft de psycholoog door haar deskundigheid een gesprek tussen de echtelieden tot stand kunnen brengen, ondanks maar ook dankzij de emoties. Zij heeft de transitie die plaatsvond begeleid zodat er weer naar de toekomst gekeken kon worden. Dat is de meerwaarde van de psycholoog als professional in deze casus.

Er is echter ook een meerwaarde op het gebied van die andere, organisatorische grens. In de situatie van mevrouw Van Wychen wordt beschreven dat de contacten tussen patiënt, naasten, verpleegkundigen en arts goed zijn en er open communicatie is. Voordat het beschreven gesprek plaatsvond, had de verpleegkundige gesignaleerd dat er iets veranderd was, dat meneer Van Wychen veel meer was gaan praten en mevrouw juist minder. Het was toen nog niet duidelijk wat hier de oorzaak van was. Toen de uroloog slecht nieuws had voor meneer, was nog niet helder welke impact dit had op hem. Door een andere professional in te schakelen voor dit gesprek komt de goede zorgrelatie met de verpleegkundigen niet onder druk te staan. De psycholoog kan moeilijke, schurende vragen stellen als het nodig is.

De patiënt en zijn naasten hebben dus een palet aan personen om zich heen waarbij de contacten met de een in goede harmonie verlopen en met de ander misschien niet van harte, maar wel noodzakelijk zijn. Dit geeft reliëf aan de zorg en begeleiding die niet mogelijk zou zijn wanneer die allemaal door één persoon worden gegeven.

\subsubsection{Multidisciplinair = transdisciplinair}

In een goed functionerend multidisciplinair team zijn de verschillende professionals op de hoogte van elkaars deskundigheid. In principe heeft ieder een tamelijk afgebakend taakgebied met eigen verantwoordelijkheden, vastgesteld door beroepsgroep, opleiding en organisatie van zorg. Als het gaat om psychosociale zorg in de laatste levensfase is er echter een risico dat belangrijke onderwerpen niet of onvoldoende aan bod komen, omdat gedacht wordt dat het op andermans terrein hoort. ${ }^{5}$ 
De psycholoog, de maatschappelijk werker en de geestelijk verzorger mogen van een verpleegkundige verwachten dat deze ingaat op 'moeilijke' vragen door een open en betrokken houding aan te nemen en verkennende vragen te stellen. Bijvoorbeeld als zij het vermoeden heeft dat er meer aan de hand is dan op het eerste gezicht lijkt. Juist op momenten als lichamelijke verzorging, de intiemere momenten die specifiek zijn voor de rol van de verpleegkundige, kunnen kwesties aan de orde komen die moeilijk zijn voor de patiënt. Het kunnen vragen zijn over onderlinge verhoudingen met de naasten, in de wetenschap dat deze in de laatste levensfase vaak onder druk komen te staan. Het kunnen vragen zijn op het gebied van betekenisgeving. De open vraag 'Wat betekent dit voor u?' kan waardevolle informatie opleveren, bijvoorbeeld in de eerder genoemde overgang van orale naar subcutane medicatie. Daardoor wordt duidelijk hoe de patiënt en zijn naasten de situatie beleven. Zelf initiatief nemen als verpleegkundige en actief navragen wat iemand nu inspireert, wat belangrijk is voor een persoon, waar iemand nu door geraakt wordt, kan leiden tot onverwachte en betekenisvolle gesprekken. Vervolgens is het belangrijk deze informatie goed te delen met de andere teamleden.

\subsubsection{Het lerende team}

Bij zorg in de palliatieve fase is er aandacht voor goede symptoomcontrole, verlichten van lijden op lichamelijk, psychisch en spiritueel vlak. Er wordt gestreefd naar een zo rustig mogelijk overlijden van de patiënt en nazorg voor de nabestaanden. Hiervoor kan gebruik worden gemaakt van ontwikkelde richtlijnen, protocollen en meetinstrumenten. Maar het team van behandeling en begeleiding leert het meest door regelmatig met elkaar in gesprek te gaan, door met de informatie vanuit de verschillende disciplines een beeld te vormen van een patiënt. Teamleden krijgen meer oog voor het eigen aandeel in de psychosociale zorg en kunnen hun kennis aan elkaar slijpen. De gevoeligheid voor 'kleine transities' wordt aangescherpt door er van meerdere kanten naar te kijken. En dat komt ten goede aan de zorg voor iedere individuele patiënt en zijn naasten.

Door kleine transities te herkennen en op te pakken blijft de zorg en ondersteuning dicht bij de patiënt en zijn naasten. Oog hebben voor elkaars deskundigheid biedt de samenwerking tussen verschillende disciplines een belangrijke meerwaarde.

\subsubsection{Conclusie}

Voor alle teamleden die betrokken zijn bij de zorg voor patiënten in de palliatieve fase, geldt dat een open en vragende houding bijdraagt aan goede psychosociale ondersteuning. Het gevoel van controle van de patiënt op zijn eigen situatie kan worden vergroot door aandacht te hebben voor de transities die hij en zijn naasten doormaken. Vooral de samenwerking in begeleiding bij kleine transities en een gesprek 
hierover binnen het team kunnen bijdragen aan betere zorg en ondersteuning. De deskundigheid van de psycholoog, maatschappelijk werker en geestelijk verzorger wordt daarmee overgedragen op de andere disciplines waardoor het hele team zijn kwaliteit kan verbeteren.

\section{LITERATUUR}

1 Lange, J de \& A. van Staa. Transities in ziekte en zorg, op zoek naar een nieuw evenwicht. Kenniskring Transities in Zorg, Hogeschool Rotterdam, 2003.

2 Schumacher, K.L., P.S. Jones \& I. Meleis. Helping elderly persons in transition; A framework for research and practice. In: Swanson, E. \& T. Tripp-Reimer (eds.). Life Transitions in the Older Adult; Issues for nurses and other health professionals. Springer, New York, 1999.

3 Kralik, D., K. Visentin \& A. van Loon. Transitions: a literature review. Journal of Advanced Nursing, $2006,55,320-329$.

4 Thewissen, M.H. Zorg aan stervenden in het verpleeghuis. Tijdschrift Kanker, 1999, 23(3), 16-18.

5 Swaay, A, van. Communicatie in de palliatieve fase, vragen die te weinig gesteld worden. Pallium, $2003,5(4), 20-24$. 


\section{6 DE ROL VAN FAMILIEZORGERS EN VRIJWILLIGERS}

Katrien Luijkx, Bert Vrijhoef en Jos Schols

Als genezing niet meer mogelijk is, dan komt de nadruk steeds meer te liggen op kwaliteit van leven van de patiënt zelf en van zijn naasten. ${ }^{1}$ Hierbij is contact met naaste familieleden en belangrijke anderen voor terminale patiënten van essentieel belang; zij verlenen zowel emotionele als instrumentele steun. Als de zorg in de laatste levensfase voor familieleden te zwaar wordt, kunnen vrijwilligers, zowel thuis als in hospices, een belangrijke steun zijn.

In deze paragraaf wordt de rol van familieleden en vrijwilligers voor mensen in de laatste levensfase belicht. Deze paragraaf is hoofdzakelijk gebaseerd op twee onderzoeken. In het eerste onderzoek staat de rol van vrijwilligers in de palliatieve terminale zorg centraal. Met behulp van focusgroepen, een vragenlijst en interviews zijn nabestaanden van terminale patiënten die hulp hebben gehad van vrijwilligers, ondervraagd..$^{2,3}$ In het tweede onderzoek zijn door middel van open interviews met terminale patiënten en hun familieleden belangrijke aspecten in de laatste levensfase geïdentificeerd. De patiënten uit dit onderzoek verbleven thuis of in een hospice. ${ }^{4.5}$ Citaten in deze paragraaf zijn afkomstig uit een van deze twee onderzoeken.

\subsubsection{Familie en familiezorgers}

Hoewel mantelzorg ook door vrienden, bekenden of buren verleend kan worden, zijn het meestal familieleden (meer dan $80 \%$ ), vooral kinderen (55\%) en partners $(9 \%)$, die de mantelzorg voor terminale patiënten voor hun rekening nemen. ${ }^{6} \mathrm{We}$ noemen hen daarom familiezorgers. ${ }^{7}$ Familiezorgers verlenen diverse en intensieve hulp aan naasten die terminaal ziek zijn; $92 \%$ verleent psychosociale begeleiding, $79 \%$ huishoudelijke hulp en $66 \%$ persoonlijke verzorging. Van hen combineert $52 \%$ deze drie vormen van hulp, $33 \%$ twee van deze drie vormen, terwijl 15\% zich beperkt tot één van deze vormen. ${ }^{6}$

\section{Emotionele steun}

Het contact met naaste familieleden in de laatste levensfase is van groot belang; dit geldt voor patiënten die thuis zijn, maar ook voor patiënten die hun laatste levensfase in een hospice of andere setting doorbrengen. Door het contact met belangrijke anderen wordt het dagelijkse leven, zoals het was, zo veel mogelijk voortgezet. Tegelijkertijd is het contact een bron van emotionele steun, voor de patiënt zelf en voor zijn familieleden. Het is niet verwonderlijk dat $92 \%$ van de familiezorgers concreet emotionele steun verleent aan naasten die terminaal ziek zijn. 4-6,8-10 $^{-1}$

Daarom is het voor terminale patiënten erg belangrijk om over voldoende mogelijkheden en privacy te beschikken om familieleden en anderen te kunnen ontvangen 
en ontmoeten. Als patiënten thuis zijn, is dit vaak vanzelfsprekend. De echtgenoot van een terminale patiënte zegt hierover:

Het belangrijkste voor mijn vrouw is dat zij thuis in haar eigen huis kan zijn, dat zij daar samen kan zijn met de kinderen, de familie, de buren. Zij wil en zij kan thuis haar bezoek ontvangen.

Omdat terminale patiënten over het algemeen veel zorg nodig hebben, komen er op allerlei tijdstippen veel verschillende zorgverleners over de vloer. Dat makkt het voor de patiënt soms ingewikkeld om bezoek te ontvangen. Voor verpleegkundigen en verzorgenden komt de patiënt uiteraard op de eerste plaats. Patiënten waarderen het echter bijzonder wanneer in de zorgverlening, zowel in de planning als in de uitvoering daarvan, zo veel mogelijk rekening wordt gehouden met bezoek van verwanten en belangrijke anderen.

Ook voor patiënten die niet thuis verblijven, maar die hun laatste levensfase in een hospice of andere voorziening (bijvoorbeeld de palliatieve afdeling van een verpleeghuis) doorbrengen, is contact met familieleden erg belangrijk. In ziekenhuizen bevorderen de beperkte bezoekuren het contact met familieleden niet. In hospices worden de vrije bezoekuren en de privacy om mensen te ontvangen erg op prijs gesteld. Toch kan het hospice als voorziening familieleden en vrienden afschrikken. Een terminale patiënte die in een hospice verblijft zegt:

Er komt hier minder bezoek dan er thuis kwam. Natuurlijk is het hospice wat verder weg, maar ik heb ook het idee dat het hospice hen afschrikt. Alsof ze stapels lijken in de gang verwachten. Degenen die wel komen, zijn aangenaam verrast door wat ze aantreffen.

Voor het verpleeghuis kan hetzelfde gelden.

\section{Instrumentele steun}

Familieleden geven meestal ook veel hulp bij praktische zaken; zij doen het huishouden en de boodschappen, verzorgen de patiënt, dienen medicijnen toe, houden de patiënt gezelschap en zijn beschikbaar als dat nodig is. Omdat terminale patiënten intensieve zorg nodig hebben, veelal gedurende 24 uur per dag, zou het voor veel patiënten onmogelijk zijn om thuis te blijven als familiezorgers niet bereid zouden zijn om voor hen te zorgen. Met name patiënten die samenwonen met een partner (of andere familiezorger), blijken thuis te kunnen blijven wonen tot aan hun overlijden..$^{4,5,12}$ Partners verlenen intensieve zorg, inclusief intieme persoonlijke zorg, 
vaak zelfs als dat ten koste gaat van henzelf."1-13 Voor verpleegkundigen en verzorgenden betekent dit dat familiezorgers in de thuissituatie volwaardige partners in zorg zijn. De zorg voor de patiënt dient dan ook goed met de familiezorgers afgestemd te worden.

Familiezorgers zijn over het algemeen en met betrekking tot palliatieve zorg in het bijzonder erg bereid om zorg te verlenen. Omdat patiënten in hun laatste levensfase vaak gedurende 24 uur per dag intensieve zorg nodig hebben, is het heel goed mogelijk dat de zorgverlening op een gegeven moment te zwaar wordt, zeker als de palliatieve fase lang duurt. Vrijwilligers kunnen dan uitkomst bieden. ${ }^{2,3}$

\subsubsection{Vrijwilligers}

In Nederland zijn momenteel ongeveer achtduizend vrijwilligers actief in de palliatieve zorg. Zij bieden thuis of in een hospice aandacht, nabijheid en ondersteuning, zowel voor terminale patiënten als voor naasten. De meeste lokaal georganiseerde vrijwilligersorganisaties zijn aangesloten bij Vrijwilligers Palliatieve Terminale Zorg Nederland (VPTZ Nederland) en zorgen ervoor dat de vrijwilligers zorgvuldig worden geselecteerd en een intensieve training volgen voordat ze hulp mogen verlenen. Verder bepalen de lokale organisaties zelf wat hun dienstverlening precies inhoudt. Over het algemeen houden vrijwilligers de patiënt gezelschap, verlenen lichte persoonlijke verzorging en emotionele steun aan de patiënt en staan familiezorgers bij. Soms behoort 's nachts waken ook tot de mogelijkheden (zie ook www.vptz.nl). De ondersteuning van vrijwilligers is een aanvulling op familiezorg en betaalde hulp.

\section{Vrijwilligers thuis}

Voor patiënten en familiezorgers is het niet vanzelfsprekend om vrijwilligers om ondersteuning in de palliatieve zorg te vragen. Ten eerste is niet algemeen bekend dat deze vrijwilligers bestaan en wat zij dan precies kunnen doen. Daarnaast zijn vaak al veel hulpverleners bij de zorg voor de patiënt betrokken, waardoor het onaantrekkelijk is om hierbij nog meer mensen te betrekken. Ten slotte is het voor familiezorgers moeilijk om te erkennen dat de zorgverlening voor hen eigenlijk te zwaar is. Zeker partners moeten nogal eens door de rest van hun familie tegen zichzelf in bescherming genomen worden. Een partner van een terminale patiënt zegt over de beslissing om vrijwilligers om extra hulp te vragen:

Ik zelf had er geen behoefte aan om de zorg voor mijn man met anderen te delen. I $\mathrm{k}$ vond dat niet nodig. Voornamelijk anderen vonden dat ik gebruik van vrijwilligers terminale zorg moest maken; ze zeiden dat ik het anders niet vol zou houden. 
Een andere partner zegt:

Je geeft het niet graag uit handen. Dat is het punt, je wilt het liever zelf doen.

Maar als mensen eenmaal kennismaken met vrijwilligers en de ondersteuning die zij kunnen bieden, zijn zij hierover enthousiast. Na verloop van tijd weten familiezorgers dat de patiënt in goede handen is. Dit geeft ze een betere nachtrust, de mogelijkheid om iets voor zichzelf te doen en de gelegenheid om even op adem te komen. Een echtgenote die het zelf niet zo nodig vond om van vrijwilligers hulp te ontvangen, zegt:

Ik heb eigenlijk pas de noodzaak ervan ingezien toen ze er waren. Zeker voor wat betreft die nachten heeft het voor mij wel rust betekend. Ik wist dat hij in vertrouwde handen was. De vrijwilligers wisten wat ze moesten doen.

Zelfs als een groter aantal vrijwilligers zorg verleent, zijn patiënten en familiezorgers lovend over de ondersteuning. Dat een groter aantal vrijwilligers zorg verleent, komt eigenlijk alleen voor wanneer de zorg heel intensief is. Vaak gaat het dan niet meer om de keuze wel of geen vrijwilligers, maar meer om nog thuis te kunnen blijven wonen met hulp van vrijwilligers of te verhuizen naar een voorziening, zoals een hospice of (de palliatieve unit van) een verpleeghuis. Een echtgenote vertelt:

De liefste wens van mijn man was thuis sterven. Dankzij de zorg van vrijwilligers kon ik hem thuis laten sterven.

\section{Vrijwilligers in een hospice of andere voorziening}

Als thuis wonen geen optie meer is voor terminale patiënten, kunnen zij besluiten om naar een hospice of een (palliatieve unit van een) verpleeghuis te gaan. Er wordt in het algemeen vanuit gegaan dat in hospices goede palliatieve zorg verleend wordt. 14,15 $^{2}$ De voortdurende aanwezigheid van betaalde en vrijwillige zorgverleners, die kunnen helpen als dat nodig is, is één van de belangrijke redenen om naar een hospice of andere voorziening te verhuizen. De tijd en aandacht die vrijwilligers in dergelijke voorzieningen geven, is cruciaal; zij zorgen ervoor dat er altijd iemand beschikbaar is om een praatje mee te maken, een sigaretje mee te roken of een wandelingetje mee te maken.4.5 


\subsubsection{Verwijzing naar vrijwilligers}

Door onbekendheid van de mogelijkheden en terughoudendheid om de zorg aan anderen over te laten, wordt vrij weinig gebruikgemaakt van zowel hospices als van vrijwilligers in de thuissituatie. Omdat het ten goede kan komen aan de kwaliteit van leven van de patiënt en zijn naasten, is dat jammer. Mensen die gebruikmaken van vrijwilligers in de palliatieve zorg, zijn vaak door professionele zorgverleners, zoals huisarts, verpleegkundigen of verzorgenden, op deze mogelijkheid gewezen..$^{2,3,16}$ Ook het merendeel van de patiënten die hun laatste levensfase in een hospice doorbrengen, is op deze mogelijkheid gewezen door een professional, vaak de transferverpleegkundige in het ziekenhuis of de huisarts. Als professionele zorgverleners onvoldoende van dergelijke mogelijkheden op de hoogte zijn, is deze zorg voor patiënten over het algemeen slecht toegankelijk. Daarom is het belangrijk dat professionele hulpverleners goed op de hoogte zijn van de mogelijkheden. Ook omdat familiezorgers en patiënten vaak overtuigd moeten worden van de noodzaak en meerwaarde van deze extra hulp. Van onder andere verpleegkundigen en verzorgenden mag verwacht worden dat zij patiënten en hun naasten op het juiste moment van relevante informatie voorzien en, wanneer daar aanleiding toe is, mensen proberen te overtuigen van de meerwaarde.

\subsubsection{Conclusie}

Familiezorgers spelen als vanzelfsprekend een belangrijke rol in de laatste levensfase van terminale patiënten. Het contact op zichzelf is belangrijk, maar ook de emotionele en instrumentele steun die familiezorgers aan terminale naasten verlenen. Het is belangrijk dat verpleegkundigen en verzorgenden ervoor zorgen dat de professionele zorgverlening het contact tussen patiënt en familieleden zo min mogelijk in de weg staat. Afstemming over momenten van zorgverlening met de patiënt en/of zijn naasten is daarom van belang.

Vrijwilligers kunnen in de laatste levensfase, naast familiezorgers en professionele zorgverleners, aanvullende zorg verlenen. Als de patiënt thuis is, kunnen vrijwilligers een deel van de zorg van familiezorgers overnemen, waardoor zij even op adem kunnen komen en de patiënt vaak langer thuis kan blijven. In een hospice of andere voorziening zorgen vrijwilligers voor tijd en aandacht, waardoor patiënten zich op hun gemak voelen. Als vrijwilligers eenmaal in de zorgverlening voor een terminale patiënt betrokken zijn, wordt hun hulp door patiënten en familiezorgers erg gewaardeerd. Datzelfde geldt voor een hospice; als mensen daar eenmaal zijn, zijn zij tevreden over deze voorziening. Toch worden deze mogelijkheden niet optimaal benut, door onbekendheid en doordat mensen het een grote stap vinden om extra hulp van vrijwilligers te vragen of naar een hospice te gaan. Daarom is het belangrijk dat verpleegkundigen en verzorgenden goed op de hoogte zijn van de 
mogelijkheden en er bij mensen (herhaaldelijk) op aan durven dringen om deze alternatieven in overweging te nemen.

\section{LITERATUUR}

1 WHO definition of palliative care. www.who.int/cancer/palliative/definition/en. Geraadpleegd op 16 juni 2009 .

2 Luijkx, K.G. \& J.M.G.A. Schols. Volunteers in palliative care make a difference. Journal of Palliative Care, 2009, 25, 30-39.

3 Luijkx, K.G. \& P.A.M. van den Akker. Een extra steun in de rug. Onderzoek naar ervaringen met vrijwilligers terminale zorg. IVA, Tilburg, 2003.

4 Luijkx, K.G. \& J.M.G.A. Schols. Perceptions of terminally ill patients and family members regarding home and hospice as places of care at the end of life. European Journal of Cancer Care, 2010 Oct 5. [Epub ahead of print].

5 Akker, P. van den, K. Luijkx \& S. van Wersch. Waar wilt u doodgaan? Keuzen en overwegingen. IVA, Tilburg, 2005.

6 Schellingerhout, R. De mantelzorger. In: Timmermans, J.M. (red.). Mantelzorg. Over de hulp van en aan mantelzorgers. Sociaal en Cultureel Planbureau, Den Haag, 2003, 33-58.

7 Beneken genaamd Kolmer, D.M.T., H.F.L. Garretsen \& I.M.B. Bongers. Family care: a conceptual clarification. Challenges for future health policy and practice. Eurohealth, 2004,10, 44-47.

8 Appelin, G. \& C. Berterö. Patients' experiences of palliative care in the home: A phenomenological study of a Swedish sample. Cancer Nursing, 2004 27, 65-70.

9 Gott, M., J. Seymour, G. Bellamy, et al. Older people's views about home as a place of care at the end of life. Palliative Medicine, 2004, 18, 460-467.

10 Townsend, J., A.O. Frank, D. Fermont, et al. Terminal cancer care and patients' preference for place of death: a prospective study. British Medical Journal, 1990, 301, 415-417.

11 Visser, G., et al. The end of life: Informal care for dying older people and its relationship to place of death. In: Klinkenberg, M. (ed.). The Last Phase of Life of Older People: Health, preferences and care. A proxy report study. Vrije Universiteit, Amsterdam, 2004, 107-121.

12 Arber, S. \& J. Ginn. The meaning of informal care: Gender and the contribution of elderly people. Ageing and Society, 1990, 10, 429-454.

13 Finch, J. \& J. Mason. Negotiating Family Responsibilities. Routledge, London, 1990.

14 Addington-Hall, J. \& A. O'Callaghan. A comparison of the quality of care provided to cancer patients in the UK in the last three months of life in in-patient hospices compared with hospitals, from the perspective of bereaved relatives: results from a survey using the VOICES questionnaire. Palliative Medicine, 2009, 23, 190-197.

15 Grande, G. Palliative care in hospice and hospital: time to put the spotlight on neglected areas of research (Editorial). Palliative Medicine, 2009, 23, 187-189.

16 Akker, P. van den \& S. van Wersch. Vrijwilligers terminale zorg. Een onderzoek naar de rol van intermediairen. IVA/Landelijk Steunpunt Vrijwilligers Terminale Zorg, Tilburg/Bunnik, 2001. 


\section{Specifieke aspecten van palliatieve zorg}

4.1 Zorg bij pijn en vermoeidheid no

4.2 Psychosociale zorg ing

4.3 Spirituele zorg 129

4.4 Zorg rond het sterven 135

4.5 Complementaire zorgtoepassingen in de palliatieve zorg 144

4.6 Richtlijnen voor palliatieve zorg 150 


\section{1 ZORG BII PIJN EN VERMOEIDHEID}

\section{Wim Distelmans}

Pijnklachten en vermoeidheid zijn de voornaamste klachten van patiënten in de palliatieve fase. In deze paragraaf wordt stilgestaan bij diverse aspecten van pijn en pijnbestrijding (paragrafen 4.1.1 $\mathrm{t} / \mathrm{m}$ 4.1.6) en vermoeidheid en anorexie-cachexie (paragrafen 4.1.7 t/m 4.1.9).

\subsubsection{Pijn}

Het oplossen van een ernstig, chronisch pijnprobleem illustreert goed hoe een patiënt in zijn geheel benaderd dient te worden. Het is de verdienste van Cicely Saunders geweest, de grondlegster van de palliatieve zorg, om aandacht te vragen voor het begrip totale pijn. ${ }^{2}$ Elk ziektesymptoom wordt door allerlei factoren beïnvloed en verergerd, zoals slapeloosheid, emotionele problemen of depressieve stemming. Wil men een klacht goed en globaal behandelen, dan moet men daar rekening mee houden. Ook de International Association for the Study of Pain (IASP) steunt hierop haar definitie van pijn (1979):

Pijn is een onplezierige, sensorische en emotionele ervaring die gepaard gaat met feitelijke of mogelijke weefselbeschadiging of die beschreven wordt in termen van een beschadiging. ${ }^{2}$

Pijn is dus een ervaring van de hele persoon en veel meer dan louter lichamelijke ongemakken. Pijn is een multidimensionaal verschijnsel dat zorg voor heel de mens vereist en dus vraagt om totale zorg. De patiënten hebben in dit opzicht altijd gelijk. Zelfs wanneer zij geen pijn hebben maar er toch over klagen, moet dit ernstig genomen worden. Het is wellicht een roep om aandacht. Ernstige chronische pijn wordt hoofdzakelijk bestreden met medicijnen. Maar men moet altijd oog hebben voor onderliggende emotionele en psychosociale factoren, en voor niet-medicamenteuze pijnbestrijding zoals fysiotherapie, radiotherapie, chemotherapie of heelkundige interventies.

\subsubsection{Pijn bij kanker en andere chronische pijnen}

Pijn bij kanker wordt vooral veroorzaakt door de verspreiding van de tumor zelf, zoals door uitzaaiingen naar botstructuren, zenuwbeschadiging, aantasting van organen en inname van lymfeklieren. In mindere mate is de pijn te wijten aan de kankerbehandeling, namelijk na heelkundige interventies, chemotherapie of radiotherapie. Bij de meeste kankerpatiënten wordt de pijn onderbehandeld omdat de 
zorgverleners onvoldoende kennis hebben. Toch kan tot 90\% van deze pijnsyndromen efficiënt bestreden worden of ten minste teruggebracht tot het niveau dat ze niet alles overheersen, en patiënten opnieuw aan iets anders dan pijn kunnen denken. ${ }^{3}$ Bovendien wordt pijncontrole zeer eenvoudig bereikt, namelijk door het geregeld slikken van pijnstillers.

\subsubsection{Principes van behandeling van pijn}

Het hoofdprincipe bij de behandeling van pijn is: 'Geef het juiste medicijn door de mond, op het juiste tijdstip en in de juiste dosis.' De behandeling van chronische pijn wordt bij voorkeur door de mond (oraal) toegediend. Hierdoor blijft de patiënt mobiel, zelfstandig en kan hij leren om zelf de dagdosis aan te passen. Bovendien wordt het verblijf in een ziekenhuis vermeden of gereduceerd. Veelgebruikte pijnstillers werken slechts enkele uren. Het is onlogisch om een medicament met een werkingsduur van 4 uur om de 8 uur toe te dienen. Zo creëert men pijnvrije periodes gevolgd door episodes van pijn. Wanneer de werkingsduur niet bekend is, volstaat het om de bijsluiter te lezen.

\section{T.4 De pijnladder}

De pijnladder (figuur 4.1) werd geïntroduceerd door de Wereldgezondheidsorganisatie en is een zeer praktisch hulpmiddel bij de keuze van de juiste pijnstiller. ${ }^{3} \mathrm{Hij}$ bestaat uit drie stappen en beperkt zich tot enkele medicijnen. De prototypen die bij elke stap horen, zijn respectievelijk aspirine, codeïne en morfine. Voor elk product bestaan alternatieven.

- Stap 1: Zwakke niet-morfineachtige producten (niet-opioiden). Bij beperkte pijn bevindt men zich op de eerste trede en gebruikt men niet-morfineachtige stoffen zoals acetylsalicylzuur (Aspirine ${ }^{\circledR}$ ), paracetamol (Panadol ${ }^{\circledR}$ ), indometacine (Indo$\mathrm{cid}^{\circledR}$ ), diclofenac (Voltaren ${ }^{\circledR}$ ) of celecoxib (Celebrex $\left.{ }^{\circledR}\right)$. Wanneer deze producten correct zijn gegeven (juiste dosis en tijdstip) en de patiënt blijft pijn houden, dan gaat men naar trede 2 van de ladder en start men met morfinepreparaten of opioiden. Aangezien de producten van stap 1 op een andere manier werken dan morfineachtige stoffen, mag men de producten van stap 1 blijven doorgeven tijdens stap 2 en stap 3.

- Stap 2: Zwakke morfineachtige producten. Het betreft stoffen zoals codeïne en tramadol (Tradonal®). Volstaan deze pijnstillers niet meer, dan gaat men naar de derde en laatste trede van de pijnladder: de sterke opioïden.

= Stap 3: Sterke morfineachtige producten. Morfine kan ingenomen worden als tabletten (MS Contin ${ }^{\circledR}$ ), druppels of oplossing (Oramorph ${ }^{\circledR}$ ). Alternatieven voor morfine zijn onder andere oxycodon (Oxycontin ${ }^{\circledR}$ ) of de morfinepleister met fentanyl (Durogesic $\left.{ }^{\circledR}\right)$. 


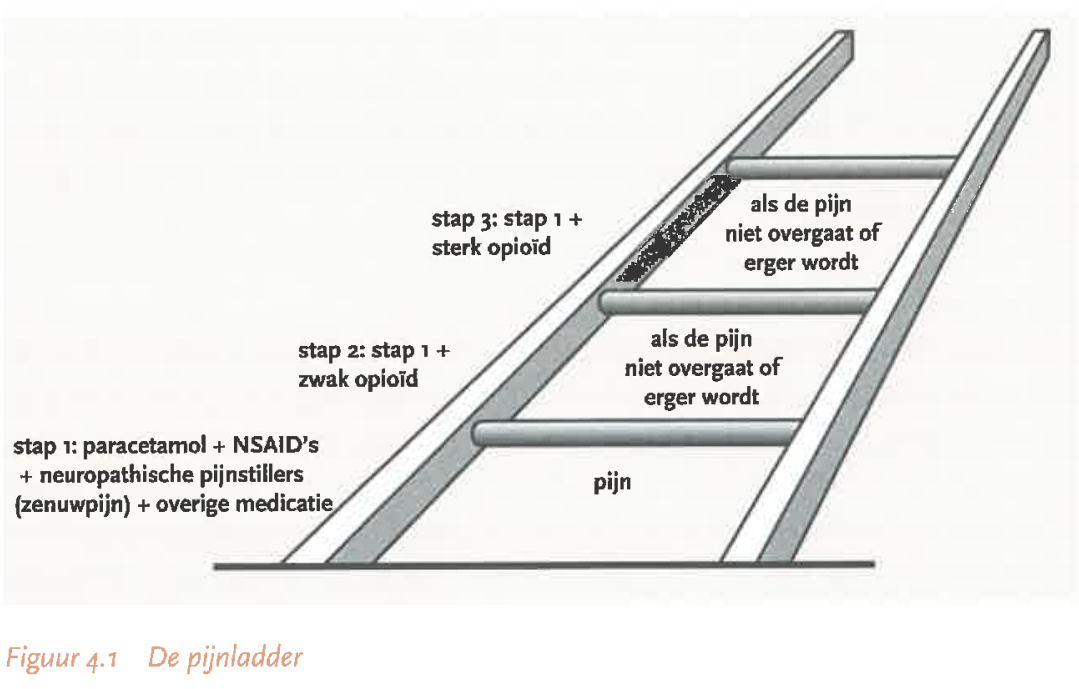

\subsubsection{Mythen over morfine}

Helaas bestaan er nog altijd veel ingewortelde vooroordelen en misvattingen over morfine. Hierdoor wordt de stof te weinig voorgeschreven en moeten nog te veel patiënten afschuwelijke pijn doorstaan. Wat zijn de meest voorkomende mythen?

- Morfine zou tot verslaving leiden. Er zijn voldoende studies gedaan bij patiënten met ernstige chronische pijn die het tegendeel hebben aangetoond. ${ }^{4}$ Verslaving of psychologische afhankelijkheid bestaat niet bij deze patiënten. Ze stoppen zelfs spontaan met morfine - ze vergeten af en toe hun pil te nemen - indien de pijn op een andere manier onder controle is gebracht zoals door bestraling van pijnlijke botmetastasen.

II Veel zorgverleners geloven dat morfinegebruik tot tolerantie leidt. Door chronisch gebruik zou morfine niet meer werken op het moment dat deze stof 'het hardst nodig is'. De misvatting is gebaseerd op vaststellingen bij drugsgebruikers. Ze moeten inderdaad na een tijdje meer en meer morfine of heroïne gebruiken om hetzelfde kickeffect te bereiken. Dit effect heeft echter niets te maken met pijnstilling.

= Ademhalingsdepressie is een andere misvatting. Wanneer de dosis morfine systematisch wordt aangepast op grond van het pijnsyndroom, is er echter geen gevaar voor ademhalingsdepressie door morfine. Pijn is immers één van de krachtigste stimuli van het ademhalingscentrum.

III Patiënten onder morfine zouden zombies zijn. Patiënten zouden onder morfine zo suf rondlopen, dat het precies levende doden zijn. Dit is gebaseerd op meldingen van mensen die een slecht gedoseerde, te hoge dosis morfine kregen en van drugsgebruikers zonder pijn. 
In Velen associëren het opstarten van morfine ook met een naderende dood. Het tegendeel kan echter het geval zijn. Een pijnvrije patiënt, die hierdoor beter slaapt, meer eetlust krijgt en meer uit bed stapt, zal bijvoorbeeld minder risico lopen op een longontsteking met dodelijke afloop. Morfine wordt trouwens ook toegediend aan patiënten met ernstige pijn door vergevorderde invaliderende artrose, wat geen levensbedreigende ziekte is.

" Morfine zou het aantal zelfmoorden verhogen. Die angst is onterecht. Er zijn voldoende gegevens dat zelfmoord bij kankerpatiënten niet extreem hoger ligt dan bij anderen. ${ }^{4}$

\subsubsection{Toegevoegde medicatie bij pijn}

Pijnstillers kunnen op elke trede van de pijnladder ondersteund worden door zogenoemde adjuvante of toegevoegde medicatie. Deze 'hulpstoffen' verbeteren ofwel het effect van de pijnstiller - daarom worden ze ook wel coanalgetica genoemd - zoals corticoïden, ofwel verminderen ze de nevenwerkingen ervan zoals laxantia, antibraakmiddelen en psychostimulantia. Het gebruik van coanalgetica werd ingevoerd omdat bepaalde chronische pijnsyndromen minder goed of zelfs slecht gecontroleerd worden door morfine. ${ }^{5}$ Voorbeelden van gedeeltelijke morfineresistente pijn zijn pijn in zachte weefsels zoals de spieren en verhoogde druk in de schedel bij hersenmetastasen. Morfine controleert tevens slecht de pijnen bij spierspasmen of bij zenuwbeschadiging: neuropathische pijn. Zenuwpijn uit zich als een oppervlakkig branderig gevoel, vergezeld van 'elektrische' pijnscheuten. Aantasting van het autonome zenuwstelsel manifesteert zich ten slotte als vasodilatatie - rode, gezwollen en warm aanvoelende huid - en veranderingen in transpiratie.

\subsubsection{Vermoeidheid en anorexie-cachexie}

Iedereen kent het beeld van een kankerpatiënt zonder enige eetlust die vel over been is. Dit werd vroeger zonder veel nadenken toegeschreven aan het vernietigende karakter van de ziekte: geen eetlust - anorexie - leidde tot onvoldoende opname van voedingsstoffen en calorieën en tegelijk haalde het snelgroeiende gezwel zijn energiebehoeften uit de vetreserves van de patiënt met extreme uitmergeling - cachexie als resultaat. Een aantal observaties waren echter strijdig met de redenering: 'Niet eten doet vermageren.' Enerzijds waren er kankerpatiënten die ondanks een goede eetlust toch gewicht verloren en anderzijds vertoonden veel uitbehandelde borstkankerpatiënten nooit een uitgemergeld aspect in tegenstelling tot de meeste longkankerpatiënten. ${ }^{6}$

Men weet $\mathrm{nu}$ dat het primaire anorexie-cachexiesyndroom een specifieke entiteit op zich is, veroorzaakt door stoornissen van de stofwisseling. In dit geval is er sprake van een abnormale stofwisseling van suikers, eiwitten en vetten. Die geeft aanleiding tot anorexie, uitmergeling, vermoeidheid en gewichtsverlies. Bovendien 
kunnen allerlei uitlokkende factoren dit syndroom verergeren. Factoren die tot secundaire anorexie-cachexie leiden, zijn onder andere slikproblemen, bijvoorbeeld door radiotherapie, misselijkheid en braken, droge, ontstoken mond en smaakverandering door chemotherapie, chronische infecties, hartfalen, long- en nierlijden, levercirrose, psychosociale en spirituele stress. Zoals aangegeven werden deze secundaire factoren vroeger als de enige oorzaak van de anorexie en uitmergeling beschouwd.

De vermoeidheid bij primaire anorexie-cachexie mag niet verward worden met verschillende aandoeningen die eveneens tot asthenie leiden. De term asthenie betekent verlies van energie, algemene zwakheid en het snel vermoeid raken bij lichaamsbeweging. Het is een vaak voorkomend symptoom bij terminale aandoeningen en maakt - zoals vermeld - ook deel uit van het anorexie-cachexiesyndroom.

Patiënten met vergevorderde kanker of aids hebben een abnormale spierfunctie, maar de onderliggende oorzaak is onduidelijk. Beperkte voedselinname kan ertoe bijdragen, maar een verbeterde voeding verandert de toestand gewoonlijk niet. Bij stervende patiënten is progressieve verzwakking een normaal onderdeel van het sterfproces.

Veel van de oorzaken van asthenie zijn potentieel omkeerbaar. Ze kunnen gekoppeld zijn aan de ziekte zelf (langdurige inactiviteit veroorzaakt bijvoorbeeld atrofie) of aan de behandeling ervan. Asthenie is een veelvoorkomende bijwerking van radioen/of chemotherapie, maar in deze gevallen treedt er binnen twee weken na het beëindigen van de behandeling verbetering op. De evaluatie moet vooral de ernst van de asthenie inschatten en de effecten ervan op de graad van autonomie en het psychologisch welzijn van de patiënt.

Specifieke effecten moeten in het oog worden gehouden; zo kan verzwakking van de ademhalingsspieren dyspnoe veroorzaken en moeilijkheden om het slijm te evacueren. Patiënten met een progressieve gegeneraliseerde zwakheid zijn er zich meestal van bewust dat de dood nabij is. Dit kan angst veroorzaken, droefheid en/of depressie.

Samenvattend kan gesteld worden dat vermoeidheid veroorzaakt kan worden door de te behandelen oorzaken zoals bloedarmoede, depressie, chemotherapie en radiotherapie, het gebruik van corticoïden en diuretica, slapeloosheid, chronische infecties en koorts, of uitdroging. Zoals steeds moet men zich altijd afvragen in hoeverre het nog zinnig is om deze oorzaken te willen behandelen.

\subsubsection{Het primaire anorexie-cachexiesyndroom}

Het primaire anorexie-cachexiesyndroom heeft dus niets te maken met de eerder genoemde uitlokkende factoren of met aandoeningen die tot vermoeidheid leiden. De cachexie is dus niet alleen een gevolg van anorexie. Bij kankerpatiënten die nog geen anorexie vertoonden, heeft men een abnormaal metabolisme kunnen vaststellen. ${ }^{4}$ Kunstmatige toediening van voedsel kan dit syndroom trouwens niet omkeren. Het ligt evenmin aan hogere energiebehoeften van de groeiende tumor. Veel 
menselijke tumoren hebben een metabolische activiteit die vergelijkbaar of zelfs lager is dan van normaal weefsel. Bovendien is de cachexie afhankelijk van het type kanker. Het komt bijvoorbeeld vooral voor bij long- en pancreastumoren, veel minder bij borstkanker.

Men heeft bepaalde stoffen - cytokinen - ontdekt die interfereren met de stofwisseling van de patiënt. Cytokinen spelen bij gezonde mensen een rol bij onder andere infecties. Bij kankerpatiënten komen ze echter in zeer grote hoeveelheden voor. De studie van het anorexie-cachexiesyndroom blijft ingewikkeld omdat deze stoffen zeer moeilijk op te sporen zijn. Cytokinen zijn immers, in tegenstelling tot hormonen, zeer lokaal actief en komen slechts beperkt of kortstondig in de bloedbaan terecht. Het primaire anorexie-cachexiesyndroom komt uitsluitend voor bij ongeneeslijke patiënten. Het voornaamste doel is dus het verbeteren van het comfort door het opheffen van de uitlokkende factoren, de zogenoemde secundaire anorexie-cachexie zoals misselijkheid en braken, slikproblemen, depressie en pijn, die de anorexie onderhoudt. Vermoeidheid is een triest gevolg van dit syndroom waar weinig aan gedaan kan worden. Er moet zeker ook meer aandacht besteed worden aan body image of het 'veranderd lichaamsbeeld': de kleding is te wijd geworden, de oogkassen raken ingevallen. Dit kan immers erg deprimerend werken.

\subsubsection{Het verbeteren van de voedingsstatus door kunstmatige voeding}

Kunstmatige voeding via een sonde of een ader heeft geen effect op de levensverwachting. Men moet dus goed overwegen of men deze kunstmatige voeding opstart. Eenmaal begonnen is het om psychologische redenen niet meer zo gemakkelijk om ermee te stoppen. Er bestaan uitzonderingen waarin tijdelijke kunstvoeding bij ongeneeslijke patiënten wel nuttig is. Slechte wondgenezing, infecties en andere complicaties na een operatie kunnen hierdoor vermeden worden. Bij bestraling van hoofd- en halstumoren ontstaan tijdelijke slikproblemen met verminderde voedselopname die op deze wijze gecompenseerd wordt. Het volgen van een bepaald dieet heeft maar gedurende drie weken effect. Het is vooral van belang de familie te overtuigen dat 'forceren' tot meer eten het levenscomfort weinig beïnvloedt en het zelfs kan aantasten. Dit leidt frequent tot frustraties bij beide partijen. De familie is ongelukkig omdat de patiënt het 'heerlijke' stoofpotje terzijde schuift. De patiënt wordt door de geur misselijk en krijgt een dip omdat hij de verwachtingen van de familie niet kan inlossen. Het blijft zeer moeilijk en haast onbespreekbaar om de stelregel 'eten is gezond' opzij te schuiven.

Dit heeft niet uitsluitend te maken met het naderende einde en het afscheid. Eten en drinken geven is één van de weinige dingen die men nog voor de ongeneeslijke patiënt kan doen. Daarom moet de zorgverlener aanvaardbare alternatieven suggereren: frequente maar kleine hapjes bereiden en de patiënt geven waar hij zin in heeft: roomijs, trappistenbier, bepaalde koekjes, champagne. Klassieke gezondheidsvoorschriften, zoals 'mag hij wel een glas wijn drinken?', zijn hier niet aan de orde. Zelfs 
wanneer de patiënt morfine gebruikt, riskeert hij enkel een wat langere of betere slaap. Medicijnen zoals metoclopramide (Primperan ${ }^{\circledR}$ ), progestativa (Megace ${ }^{\circledR}$ ) en medroxyprogesteron (Medrol ${ }^{\circledR}$ ) kunnen een (tijdelijk) effect hebben op de eetlust, de misselijkheid en het gevoel van welzijn.

\subsubsection{Conclusie}

Pijn en vermoeidheid komen bij palliatieve patiënten zeer frequent voor. Toch is ernstige, chronische pijn in de meeste gevallen uitstekend behandelbaar met orale medicatie. Het is voldoende om de eenvoudige principes van de Wereldgezondheidsorganisatie toe te passen. Daarentegen is vermoeidheid door het anorexie-cachexiesyndroom minder goed behandelbaar. Anorexie-cachexie is een complex syndroom. De oorzaak is nog steeds niet goed bekend. Hierdoor zijn er weinig therapeutische mogelijkheden beschikbaar. Kunstmatige voeding heeft weinig zin, tenzij om een acuut probleem op te lossen. Medicamenteus kan men een proeftherapie met metoclopramide, corticoïden (kort werkzaam) of progestativa (langer actief) uitproberen. Men kan proberen om de uitlokkende factoren zo goed mogelijk te bestrijden. Vooral de psychosociale ondersteuning van de patiënten en hun familie is van belang: het taboe doorbreken dat 'goed eten' alles wel zal oplossen. Het verbeteren van het levenscomfort is cruciaal en niet de gewichtstoename. Weegschalen kunnen dus beter in de ban worden gedaan.

\section{LITERATUUR}

1 Saunders, C. The symptomatic treatment of incurable cancer. Prescribers Journal, 1964, 4, 68-73.

2 International Association for the Study of Pain. Subcommittee on taxonomy of pain terms: a list with definitions and notes on usage. Pain, 1979, 6, 249-252.

3 Cancer pain relief. World Health Organization, Geneva, 1996.

4 Hanks, G., Cherny, N., Christakis, N., et al. (eds.). Oxford Textbook of Palliative Medicine, $4^{\text {th }}$ ed. Oxford University Press, Oxford, 2009.

5 Distelmans, W. Een waardig levenseinde, 6e druk. Houtekiet, Antwerpen, 2010.

6 Symptoombestrijding bij terminale aandoeningen (World Health Organization, Geneva). Forum Palliatieve Zorg, Wemmel, 2010. 


\subsection{PSYCHOSOCIALE ZORG}

\section{Sabien Bauwens}

Verpleegkundigen, verzorgenden en behandelende artsen zijn de eerste professionele zorgverleners op wie ernstig zieken terugvallen voor emotionele steun na slecht nieuws, tijdens een zware behandelingsperiode, maar ook tijdens de laatste levensfase wanneer genezen niet langer een mogelijkheid is. De manier waarop deze zorgverleners die taak op zich nemen, kan een belangrijk stempel drukken op het verwerkingsproces van de patiënt. Voor veel patiënten en hun naasten zal de aanwezigheid van een deskundige, zorgzame en empathische zorgverlener die op een gevoelige en eerlijke manier informatie kan verstrekken, volstaan. Deze direct betrokken zorgverlener dient zich echter niet alleen bewust te zijn van het eigen belang in die eerste opvang, maar hij of zij moet ook adequaat kunnen inschatten welke patiënten voordeel hebben bij een doorverwijzing naar een intensievere ondersteuning door een psychosociaal zorgverlener van binnen of buiten het eigen team, zoals sociaal werkers en (ziekenhuis)psychologen. Sommige situaties zijn bovendien bijzonder complex en vragen een tussenkomst van een nog meer gespecialiseerde hulpverlener zoals een psycholoog, psychiater, psychotherapeut met ruime ervaring in specifieke psychosociale interventies. ${ }^{1,2}$

\subsubsection{Het belevingsperspectief van de patiënt}

Gedurende het gehele ziekteproces worden de patiënten geconfronteerd met emotioneel stressvolle situaties zoals fysieke last, uitputtende behandelingen, veranderingen in uiterlijk, maar bovenal ook met continue verlieservaringen zoals verlies van gezondheid, autonomie, rol in het gezin, sociale contacten, carrière en status, toekomstplannen, zingeving en niet in het minst het verlies van controle op het eigen leven. Soms volgen de verlieservaringen tijdens het ziekteverloop elkaar snel op. Het voortdurende mentale aanpassingsproces kan leiden tot een emotionele uitputting en een vermindering van mentale weerbaarheid, vaak gepaard gaande met tekenen van ernstige distress, die qua aard en intensiteit van persoon tot persoon erg kunnen verschillen. Dit kan gaan van normale gevoelens van kwetsbaarheid, droefheid en angst tot ernstigere problematiek zoals depressie, angststoornis, paniek, sociale isolatie of existentiële en spirituele crisis. ${ }^{3}$ Om de emotionele gevolgen voor iemand goed te kunnen inschatten, rijst telkens opnieuw de vraag: wat betekent deze ziekte voor deze persoon op dit moment van zijn leven, rekening houdende met zijn eigen levenscontext (achtergrond, familiale en sociale omgeving, opvattingen en waardepatroon, ervaringen, enzovoort). 


\subsubsection{Angst en angststoornis}

Angst is een normale emotionele reactie op de onzekerheid die de ziekte teweegbrengt. Zeker wanneer het duidelijk begint te worden dat verdere behandelingen geen baat meer hebben en de dood nadert, kunnen gevoelens van angst toenemen. Angst kunnen we herkennen door observatie en luisteren. Angstige zieken rapporteren soms dat ze zich gespannen of prikkelbaar voelen of dat ze zich moeilijk kunnen ontspannen. Angst uit zich ook vaak in somatische verschijnselen zoals rillingen, spierpijnen, moeheid, transpiratie, diarree, hartkloppingen, slikproblemen, een krop in de keel, duizeligheid, slaapproblemen, ademhalingsmoeilijkheden. Deze lichamelijke kenmerken zijn echter geen sluitende criteria, aangezien er een mogelijke overlap kan bestaan met symptomen van de ziekte zelf of met de gevolgen van behandelingen. Soms zijn de somatische en psychische symptomen minimaal, maar kunnen we de aanwezigheid van angst afleiden uit een aantal gedragssignalen. Patiënten die regelmatig conflicten uitlokken, zijn vaak angstig. Angst kan zich uiten in het extreem opeisen van aandacht van artsen of verpleegkundigen, of in verzet tegen de regels en voorschriften van de instelling. Patiënten die voortdurend klagen dat ze bepaalde informatie niet gehad hebben, ondanks dat ze deze informatie al meermaals kregen, zijn vaak angstig. Ook pijn die met medicatie maar moeilijk onder controle te krijgen is, kan een uiting zijn van een onderliggend angstprobleem. Globaal genomen kunnen we angst bij levensbedreigende ziekte in drie vormen onderbrengen: reactieve angst, organisch geïnduceerde angst en pathologische angst of angststoornis.

\section{Reactieve angst}

Deze vorm gaat over angstreacties die uitgelokt worden door de ziekte zelf, door bepaalde persoonseigenschappen en/of door existentiële factoren. Voorbeelden hiervan zijn:

= angst voor pijn of symptomen: pijn die verergert of niet gecontroleerd kan worden, kortademigheid, een wond die niet geneest, enzovoort. De angstreacties op deze symptomen verlagen op hun beurt de drempel voor fysiek lijden, in het bijzonder de pijndrempel. Het gevoel van kortademigheid kan door hyperventilatie bij angst versterkt worden. Angst kan vicieuze cirkels creëren die de levenskwaliteit van de patiënt verder ondermijnen.

wiv angst voor controleverlies: het gevoel geen inspraak meer te hebben, de angst voor het verlies van het 'zelf';

* angst voor eenzaamheid en verlatingsangst: angst om 'alleen' te moeten sterven, zonder de veilige nabijheid van vertrouwden;

" angst om wat komt niet aan te kunnen: angst om te 'crashen' en niet op een 'waardige' manier afscheid te kunnen nemen;

II angst voor onzekerheid van de toekomst: het onbekende boezemt vaak angst in, wat staat er mij nog te gebeuren, hoe zal ik sterven? 
w angst voor afhankelijkheid en voor het betekenen van een last voor de omgeving, vooral bij mensen die steeds zeer onafhankelijk in het leven hebben gestaan;

= angst voor de dood: de existentiële angst hoe het voelt om er niet meer te zijn;

II angst voor het afscheid: angst en rouw over het verlies van dierbaren, spijt over het niet meer kunnen meemaken van betekenisvolle momenten in het leven van hun dierbaren.

\section{Organisch geïnduceerde angst}

Deze vorm van angst wordt veroorzaakt door medische of organische factoren, zoals door:

w pijn: slecht gecontroleerde pijn kan de patiënt angstig maken voor de pijn die zal komen;

= metabole ontregeling zoals hypoglykemie, hypercalciëmie;

= endocriene stoornissen zoals hyperthyreoïdie, bijniertumoren;

- delier;

- bepaalde medicatie zoals corticosteroïden, opioïden, benzodiazepinen (paradoxale reactie);

- extrapiramidale bijwerkingen bij het gebruik van bepaalde anti-emetica en antipsychotica;

- antiparkinsonmedicatie met angst ten gevolge van hallucinaties of acathisie (bewegingsonrust) ten gevolge van bepaalde neuroleptica zoals metoclopramide en haloperidol.

\section{Pathologische angst}

$\mathrm{Na}$ een periode van extreme angst slagen de meeste patiënten erin om door het hanteren van verwerkingsmechanismen deze angst te reduceren tot een aanvaardbaar niveau. Wanneer hen dit niet lukt, kan de angst een proportie aannemen die een bijkomende professionele opvolging nodig maakt. Bij een levensbedreigende ziekte is het onderscheid tussen normale en pathologische angst of een angststoornis niet steeds gemakkelijk te maken. Signalen die mogelijk op een angststoornis wijzen en een doorverwijzing naar meer gespecialiseerde hulp nodig maken, kunnen bijvoorbeeld de volgende vormen aannemen:

= patiënten die niet kunnen antwoorden op vragen naar hoe ze zich voelen, maar voortdurend in gedachten zijn of luidop met hun ziekte bezig zijn;

w patiënten die zich niet kunnen afleiden, niet afgeleid kunnen worden, die zich niet kunnen ontspannen of niet aan een normaal gesprek kunnen deelnemen;

= patiënten die moeilijk beslissingen kunnen nemen over hun behandeling of die niet in staat zijn de voorschriften op het gebied van medicatie of behandeling op te volgen ten nadele van hun eigen comfort. 
Patiënten die een angststoornis ontwikkelen, hadden al vaak premorbide een angstprobleem. Personen met premorbide angstproblematiek dienen intensief begeleid te worden aangezien de kans op de ontwikkeling van een angst- of paniekstoornis, een depressie of een andere psychische decompensatie bij hen groot is. Psychofarmaca kunnen hierbij een belangrijke ondersteunende rol spelen.

\section{Samenvatting}

In welke vorm angst zich ook voordoet, angst kan het bespreekbaar maken of oplossen van praktische en emotionele problemen sterk in de weg staan. Angst werkt verlammend op het denken, voelen en de activiteit van de patiënt en ondermijnt aldus de kwaliteit van zijn leven. Om een angstprobleem goed te kunnen opvangen, is het belangrijk om inzicht te krijgen in de oorzaak ervan en samen met de patiënt die mogelijke oorzaken te gaan uitzoeken. Een gesprek samen met de arts of verpleegkundige waarin de zieke openlijk zijn angsten kan uitspreken en waarin hij verduidelijkende informatie krijgt, kan soms al wonderen doen. ${ }^{4.5}$

\subsubsection{Verdriet, aanpassingsproblematiek en depressie}

Gevoelens van verdriet en droefheid door verlies zijn normaal, zeker gedurende de laatste levensfase waarin de patiënt beseft dat er geen kansen meer zijn op genezing. De patiënt kan bedroefd zijn omwille van de reeds geleden verliezen door de ziekte, maar is ook vaak bedroefd voor de verwachte verliezen, en vertoont dan een voorafgaande rouw waarin hij treurt om een verlies dat hem te wachten staat. Het is niet steeds gemakkelijk voor zorgverleners het onderscheid te maken tussen een tijdelijke episode van intense droefheid en een toestand van depressie die extra professionele behandeling vraagt. Sommigen stellen dat alle patiënten met een levensbedreigende aandoening psychische hulp nodig hebben, anderen dat er geen sprake is van gestoorde reacties, dat emotionele ontreddering bij een dergelijke aandoening normaal is en dat bijkomende hulp op emotioneel vlak om die reden niet nodig is. Vandaar dat de problematiek ook hier dikwijls als een continuüm wordt voorgesteld, gaande van droefheid als een normale reactie op de aandoening tot depressie als problematische reactie. In het midden van het continuüm worden dan die patiënten gesitueerd, die (tijdelijk) problematisch reageren omdat ze zich moeilijk kunnen aanpassen aan de veranderde situatie, maar (nog) niet beantwoorden aan alle criteria van een depressieve stoornis. Men spreekt hier dan over een aanpassingsstoornis. Ondanks het hoge percentage patiënten met een aanpassingsstoornis of depressie blijft het merendeel van deze psychische problematiek onopgemerkt en onbehandeld door professionals. ${ }^{6}$ Een van de redenen hiervoor is dat patiënten meestal niet spontaan psychische klachten melden, uit angst om extra beslag te leggen op de tijd van de zorgverleners of omdat ze denken dat ze zelf schuld hebben aan hun negatieve gemoedstoestand en daarom hun klachten achterhouden. Meer en meer wordt er dan ook wereldwijd gepleit voor zowel een systematische screening naar distress 
bij deze patiënten aan de hand van gevalideerde meetinstrumenten als de behandeling daarvan.

\section{Aanpassingsstoornis}

Aangezien er geen universeel geaccepteerde criteria zijn voor aanpassingsstoornis en depressie bij medisch zieken, vallen we noodgedwongen terug op de in de psychiatrie gebruikte criteria in de Diagnostic and Statistical Manual of Mental Disorders (DSM-IV). ${ }^{7}$

- De psychologische symptomen zijn erger dan dat men bij een normale stressreactie kan verwachten. Dit betekent dat de patiënten in duur of in intensiteit angstiger, depressiever, regressiever of agressiever zijn dan men gezien de toestand zou verwachten. De vraag is dan natuurlijk: wat is normaal in dergelijke 'abnormale' of levensbedreigende situaties.

= Meestal treedt de reactie op binnen drie maanden na de aanleiding, in dit geval de diagnose, een vastgestelde progressie van de ziekte, of een ander cruciaal moment, namelijk het inzetten of stopzetten van een therapie.

in Meestal zijn de symptomen uitingen van depressieve aard, met huilbuien, wanhoop, soms ook met schuldgevoelens en dikwijls ook in combinatie met angstsymptomen en agitatie. Prikkelbaarheid naar de overige familieleden, nervositeit en slaapstoornissen komen ook vaak voor.

\section{Depressie}

Volgens dezelfde DSM-IV moet minstens één van de volgende twee basiskenmerken aanwezig zijn en dit constant of gedurende het grootste deel van de dag:

- een depressieve gemoedstoestand, bijna elke dag;

= vermindering van interesse en plezier in alle of bijna alle activiteiten gedurende het grootste deel van de dag, bijna elke dag.

Daarnaast moeten er nog minstens vier andere symptomen aanwezig zijn:

a duidelijke gewichtsvermindering;

" slapeloosheid of overmatige slaperigheid, en dit bijna ellke dag;

= psychomotorische agitatie of remming;

- moeheid of verlies van energie, en dit bijna elke dag;

= gevoelens van waardeloosheid ofwel buitensporige of onterechte schuldgevoelens;

-1. verminderd vermogen tot nadenken of concentratie, of besluiteloosheid;

iiv terugkerende gedachten aan de dood en terugkerende suïcidegedachten.

Belangrijk bij het stellen van de diagnose depressie bij mensen met een levensbedreigende aandoening is dat men zich realiseert dat een aantal biologische criteria die gehanteerd worden voor depressie, zoals de hierboven aangegeven slapeloosheid, 
verlies aan energie, moeheid, gewichtsverlies, psychomotorische traagheid, minder waarde hebben als criteria, omdat ze vaak gemeenschappelijk zijn met symptomen van de ziekte zelf. Meer bruikbare criteria zijn psychologische kenmerken zoals lusteloosheid, hopeloosheid en vooral de aanwezigheid van schuldgevoelens, gevoelens van waardeloosheid en zinloosheid en suïcidale gedachten.

\section{Risicofactoren voor een depressieve problematiek ${ }^{8}$}

Een aantal predisponerende factoren voor depressie zijn bekend, zoals personen met chronisch niet-gecontroleerde pijn, jonge patiënten, fysieke performantiestatus, gebrek aan sociale steun, eenzaamheid, recente verlieservaring. Een tweede groep van risicofactoren voor depressie hangt samen met de ziekte zelf en de behandeling, zoals het soort kanker (bijvoorbeeld hoofd-halstumoren en pancreaskanker), bepaalde medicaties zoals corticosteroïden (dexamethason en prednisolon), bepaalde cytostatica (zoals vincristine, vinblastine, procarbazine, asparaginase), immunotherapie (zoals interferon en interleukine-2) en hormonale therapie, een gevorderd stadium van ziekte, of bepaalde metabolische, endocrinologische en neurologische condities (zoals hersenmetastasen, bijnierinsufficiëntie, hypercalciëmie, hypothyreoïdie). Als algemene risicofactoren kunnen beschouwd worden: eerdere depressie of andere gemoedsstoornis in het verleden, alcohol- of ander middelenmisbruik en familiale belasting.

\section{Doorverwijzen bij depressieve problematiek}

Aangezien in palliatieve zorg verbetering van levenskwaliteit voorop staat, is een adequate behandeling van depressie cruciaal. Depressie kan op allerlei niveaus de kwaliteit van leven negatief beïnvloeden, gaande van therapieresistente lichamelijke klachten, therapieontrouw, verlies aan gevoel voor zelfwaarde, tot het vervreemden van omgeving en het wegvallen van de communicatie. Het afscheid nemen van geliefden wordt hierdoor onmogelijk. Depressie kan behandeld worden door gespecialiseerde hulpverleners, waarbij vaak de combinatie van psychotherapeutische interventies en de juiste psychofarmaca de effectiefste behandeling vormt. Een tijdige doorverwijzing is erg belangrijk.

\subsubsection{Verwerking en copingreacties}

Extreme emoties zetten een aanpassingsproces bij de zieke in gang om het lichamelijk, psychisch of sociaal welzijn zo veel mogelijk te herstellen. De intense angst die gepaard gaat met de confrontatie met een overweldigende bedreiging zoals de dood, leidt in eerste instantie op fysiologisch niveau tot een 'vecht-of-vluchtreactie', nog voor er mentaal een angstreactie doordringt. Om deze angst te hanteren hebben mensen een hele reeks van copingstrategieën of vrij vertaald psychologische verwerkings- of verdedigingsmechanismen ontwikkeld.

Mensen kunnen in eenzelfde situatie sterk verschillende verwerkingsreacties vertonen. Globaal gezien zouden we kunnen zeggen dat sommigen eerder de 
angstaanjagende situatie onder ogen zullen zien en dat anderen deze eerder proberen te vermijden; sommigen zullen een actieve houding innemen tegenover de dreiging, anderen reageren dan weer voornamelijk passief. Mensen grijpen vaak terug naar verwerkingsmechanismen die hen eerder al geholpen hebben, maar in onbekende situaties, zoals de eigen naderende dood, kunnen ze soms niet op hun bekende efficiënte 'copingmanier' terugvallen en zijn ze gedwongen nieuwe strategieën te ontwikkelen. Zo kunnen soms verschillende verwerkingsreacties in mindere of meerdere mate naast elkaar aanwezig zijn, afwisselend of tegelijk. In een onderzoek hierover vonden Greer en Watson vijf vaak voorkomende copingstijlen bij kankerpatiënten. ${ }^{9}$

* Fighting spirit of vechthouding. Deze patiënten stellen alles in het werk om te genezen en stellen zich actief op bij de behandeling. Een vechthouding wil niet zeggen dat deze patiënten nog denken dat ze zullen genezen. De vechthouding kan zich ook subtieler uiten, zoals het zich voortdurend stellen van doelen op korte tot middellange termijn.

w Fatalisme. Dit zijn de patiënten die reageren met een houding van passieve aanvaarding, berustend in hun lot. Voor sommige zieken biedt zo'n houding een bescherming tegen angst en depressie, bij anderen zien we dat deze passieve aanvaardende houding leidt tot lusteloosheid en gebrek aan plezierbeleving met gevaar voor depressie.

* Hopeloosheid en hulpeloosheid. Dit zijn patiënten die een catastrofale reactie vertonen. Deze patiënten voelen zich vaak overweldigd door de bedreiging en hebben een gevoel van volledig verlies aan controle. Het zijn patiënten die op een passieve manier reageren, die nooit zelf het initiatief nemen. Dit vormt ook een risicogroep voor het ontwikkelen van angstproblematiek en depressie.

- Angstige bezorgdheid. Dit zijn de patiënten die zeer angstig reageren en voortdurend op zoek zijn naar geruststelling, maar moeilijk gerustgesteld kunnen worden. Deze patiënten lopen gevaar om een angst- of paniekstoornis te ontwikkelen.

- Ontkenning. Het gaat hier over patiënten die de volledige realiteit niet bewust laten binnendringen omdat die te pijnlijk is. Men moet hier onderscheid maken tussen een aantal vormen van ontkenning. Ontkenning kan een problematische reactie zijn, maar is meestal een sterk aanpassingsgericht verwerkingsmechanisme. Meestal is de ontkenning niet volledig en gaat het om een milde ontkenning in de vorm van minimalisatie van de ernst van de aandoening. Een andere vorm van ontkenning is wat men positieve vermijding heeft genoemd. Het gaat dan om zieken die zich perfect bewust zijn van wat er aan de hand is, maar die vermijden hierover te praten. Problematisch is wat men noemt de 'majeure ontkenning' of de totale ontkenning van het ziektebeeld, waarbij deze patiënten weigeren aan te nemen dat zij ziek zijn en dus ook geen medische hulp zoeken. Majeure ontkenning is echter zeer uitzonderlijk, en deze vorm wordt meestal niet volgehouden tijdens de laatste fase van het ziekteproces. 


\subsubsection{Psychosociale zorg}

De basisdoelstelling van psychosociale zorg bij palliatieve patiënten is het verhogen van de levenskwaliteit en de levenssatisfactie van de patiënt en zijn belangrijke naasten. Concrete doelen zijn hierbij: het reduceren van distress, depressie, angst en paniek, het bijdragen aan een optimale pijn- en symptoomcontrole, en het pogen tegemoet te komen aan de fundamentele psychische behoeften van de patiënt. De Wereldgezondheidsorganisatie definieert deze als volgt:

De behoefte aan veiligheid, aan ergens bij te horen, aan affectie, de behoefte om te begrijpen, om aanvaard te worden, de behoefte aan zelfrespect en aan vertrouwen. ${ }^{10}$

Hiernaast worden ook de behoefte aan zingeving en de behoefte aan vrijheid en autonomie vaak als basisbehoeften vermeld. De focus van de zorg is hierbij telkens niet alleen de zieke zelf, maar ook de belangrijke naasten, wat ruimer ligt dan uitsluitend de familieleden.

\section{Wat helpt hierbij niet?}

Zorgverleners worden vaak geconfronteerd met moeilijke vragen ('Ben ik aan het doodgaan?') of met moeilijke situaties, bijvoorbeeld familieleden die niet willen dat de patiënt op de hoogte wordt gebracht van zijn ziektetoestand. Een vaak voorkomende reactie van de zorgverlener om zichzelf tegen dergelijke stressvolle situaties te beschermen, is het afstand nemen van de patiënt en zijn familie. Dit komt tot uiting in wat Faulkner en Maguire 'blokkeringsgedrag' noemen: blokkeringstechnieken die zorgverleners gebruiken in hun gesprek met de patiënt waardoor open communicatie en adequate psychosociale steun in de kiem worden gesmoord." Illustraties hiervan zijn bijvoorbeeld het vals geruststellen van de patiënt of het artificieel vrolijk houden van het gesprek.

\section{Wat kan wel helpen?}

Een goede psychosociale zorg kan niet zonder de klassieke pijlers empathie, openheid en echtheid als basishouding in de zorg voor de ongeneeslijk zieke en zijn familie. Hoewel steeds belangrijk in de zorg voor mensen, neemt hiernaast ook het concept waardigheid een centrale plaats in bij de palliatieve benadering. Bescherming van waardigheid is onlosmakelijk verbonden met wat men zou kunnen beschouwen als 'een goede dood'. ${ }^{2}$ De manier waarop men als zorgverlener omgaat met het lichaam van de zieke, met diens persoonlijke ruimte en privacy, met discretie, met het behandelen van een zieke als persoon, lijken evidente basisattitudes. ${ }^{13}$ Toch wordt het belang van zelfs triviale zaken, zoals kloppen op de kamerdeur van de patiënt, vaak niet voldoende naar waarde geschat als bijdrage tot het zelfrespect van de zieke persoon. Basiszorgverleners kunnen niet alleen door een correcte attitude bijdragen 
aan een goede psychosociale zorg. In de weinige tijd die er soms is, kunnen ze ook inhoudelijk bijdragen.

\subsubsection{Inhoudelijke componenten in psychosociale zorg}

Goede psychosociale zorg bestaat uit de volgende componenten.

\section{Voldoende informatie}

Het verkrijgen van voldoende uitleg en informatie is één van de belangrijke stappen bij het verwerven van een zeker controlegevoel en het verminderen van angst. Voldoende uitleg wil zeggen: uitleg op maat van de patiënt, met zijn behoefte aan temporisatie en met inachtneming voor wat de patiënt wil horen. Bovendien kan het ook nodig zijn om een weinig assertieve patiënt te stimuleren om vragen te stellen. Leren wat de aard van zijn ziekte is, wat de mogelijke verdere stappen zijn in de ziekte en de behandeling, kan een aantal misvattingen wegnemen en helpen met het gevoel van onzekerheid om te gaan. Dikwijls leven er bij patiënten en familie ook angsten of vooroordelen met betrekking tot bepaalde medicatie en kan extra informatie verhelderend werken. Het stimuleren van de patiënt om de informatie met zijn familie uit te wisselen, helpt bovendien om meer open met zijn familie of partner te communiceren. Ook het verduidelijken van bepaalde emotionele reacties van de patiënt, de familie of de staf naar elkaar toe kan zinvol zijn.

\section{Empathische aanwezigheid en ruimte voor emoties}

Door met echte interesse naar de patiënt te luisteren, vergroten we zijn gevoel voor zelfwaarde. Het benoemen van zijn emoties als herkenbaar tijdens deze ziektefase, is belangrijk om de patiënt gerust te stellen dat hij 'normaal' reageert en niet 'gestoord'. Het bespreekbaar maken van intense gevoelens en het helpen ontwarren van deze emoties, kan de zieke helpen om er meer vat op te krijgen en de mentale stress te verminderen. Bij patiënten die de confrontatie met het idee van doodgaan aankunnen, kan het helpen om hun angsten hierover te gaan onderzoeken en te identificeren. In deze gesprekken moeten we er wel op letten dat we de defensieve verwerkingsmechanismen zoals ontkenning en positieve vermijding respecteren en dat we ook het verlangen van de patiënt om hoop te bewaren niet ondermijnen. We mogen de patiënt niet dwingend confronteren met dingen waar hij niet klaar voor is. Belangrijk is dat we een veilig klimaat scheppen waarin innerlijke angsten en onzekerheden geuit kunnen worden.

\section{Het stimuleren van communicatie en het vergroten van sociale steun}

Soms is het nodig de patiënt en de belangrijke personen in zijn onmiddellijke omgeving aan te sporen tot een meer open communicatie, het delen van hun angsten of verdriet in plaats van het elkaar wederzijds beschermen. Zo kan voorkomen worden dat de patiënt in een geïsoleerde positie terechtkomt. Een verbeterde communicatic 
leidt vaak tot een vergrote intimiteit en tot een betere aanpassing aan het idee van de naderende dood. Het biedt aan de betrokkenen ook de mogelijkheid om de toekomst beter voor te bereiden en bovendien is er minder gevaar dat het rouwproces problematisch verloopt. Soms leeft er bij de patiënt of bij de familie nog de wens om bepaalde conflicten uit te praten: een gouden stelregel hierbij is om enkel faciliterend op te treden en niet normerend.

\section{Ondersteunende zorgtechnieken}

Ademhalings- en ontspanningstechnieken kunnen de patiënt helpen ontspannen en kunnen tevens zinvol gebruikt worden voor symptoomverlichting (voornamelijk bij angst en pijn). Vooral patiënten bij wie het verlies van persoonlijke controle een belangrijke rol speelt in de pijn- en symptoomervaring, kunnen door deze technieken worden geholpen. Deze technieken bieden de patiënten een methode waarbij ze hun eigen therapie en behandeling kunnen beinvloeden. Ze verminderen zo de hulpeloosheid en de demoralisatie die het gevolg zijn van de progressie van de ziekte, en de onmacht om die te stoppen.

\section{Stimuleren van deelname in beslissingen en verhogen van controle}

Terminaal zieken en hun familie moeten vaak belangrijke keuzen maken zoals beslissingen rond het al of niet voortzetten van behandelingen, beslissingen rond wie de zorg opneemt voor de patiënt, beslissingen rond wilsbeschilkingen of begrafenis. Het is belangrijk om de patiënt vanaf het begin bij deze overlegmomenten te betrekken; dit versterkt het gevoel dat hij nog steeds als een belangrijk, gerespecteerd deel van het gezin meetelt. Het ondersteunen van beslissingsprocessen houdt ook in dat de patiënten geholpen worden om de noodzakelijke informatie te verkrijgen.

\section{Maximaliseren van kwaliteit van leven}

Dit kan inhouden de patiënten helpen uitzoeken wat ze nog kunnen en willen doen of bereiken in hun leven en hen helpen die doelen te realiseren. Belangrijk is dat er realistische doelstellingen gesteld worden, bijvoorbeeld doelstellingen die iets te maken hebben met de voorbereiding op de dood en met het afscheid nemen van geliefden en vrienden. Dit kunnen belangrijke doelen zijn, zoals het afsluiten en overdragen van een eigen zaak, het doorgeven van administratie aan de partner, maar ook kleinere zoals een lijst maken met persoonlijke schenkingen. Doelen kunnen ook te maken hebben met het plannen van leuke activiteiten zoals een bezoek van een oude vriend of het samen met de familie bekijken van een geliefd programma. Het stellen van doelen kan belangrijk zijn om hoop in te vullen. Onrealistische doelen zijn niet zinvol omdat het de persoon kan weerhouden 
voorbereidingen te treffen, maar realistische hoop in de vorm van het toeleven naar een belangrijke gebeurtenis zoals het huwelijk van een zoon of de geboorte van een kleinkind, kan het leven waardevol maken en een reden zijn om door te gaan, ook in moeilijke fasen.

\section{Helpen bij het zoeken van zingeving en betekenis}

Dit sluit aan bij wat we als spirituele zorg benoemen. Sommige existentiële angsten op het eind van het leven hebben te maken met het idee dat het leven geen zin of betekenis heeft gehad. Door actief naar het levensverhaal van mensen te luisteren, door samen met de patiënt de resultaten in hun leven vast te stellen en te erkennen, door het waardepatroon achter hun keuzen te onderzoeken, vinden mensen soms een stuk levenslijn terug en een vermindering van gevoelens van waardeloosheid en zinloosheid. In paragraaf 4.3 wordt dieper ingegaan op de spirituele zorgaspecten.

\subsubsection{Conclusie}

Ziekte vindt altijd plaats in een bepaalde context. De manier waarop iemand omgaat met ernstige ziekte kan niet los gezien worden van zijn persoonlijke geschiedenis, zijn persoonlijkheid, zijn copingmechanismen en zijn sociaal netwerk. Het zal ook afhangen van zijn leeftijd, het stadium van zijn gezinsontwikkeling, het soort en verloop van zijn ziekte. Socio-economische en culturele variabelen spelen eveneens een rol. Elke ziektebeleving is dus uniek en alleen de patiënt is expert in zijn beleving. In omgang met de patiënten is de agenda van de patiënt steeds de belangrijkste. Hierbij dienen we ons voortdurend voor ogen te houden dat emotionele beleving om ruimte vraagt, niet om een oplossing. De zieke apprecieert vaak de aanwezigheid van een metgezel, iemand die met hem meeloopt, maar niet voorloopt of achterblijft in zijn ziektebeleving. Iemand die hem helpt zijn hoop te richten op comfort en betekenisvolle gebeurtenissen, niet uitsluitend op genezing. Iemand die in zijn interventies ook steeds aandacht heeft voor de familie en de directe naasten. Goede psychosociale zorg creëert keuzen. Ideaal gezien zou de zieke moeten kunnen kiezen waar en hoe hij zijn laatste dagen doorbrengt. Hiervoor moet hij op de hoogte zijn van zijn toestand, zijn prognose, eventuele behandelopties en comfortbehandelingen en de mogelijkheden van palliatieve zorg. Dit vraagt een uiterst sensitieve manier van communicatie door de zorgverlener. Zoals medicatie dient ook informatie getitreerd te worden. Zorgverleners moeten inschatten hoeveel informatie de zieke wenst te krijgen. Hij heeft het 'recht op weten' maar ook 'op niet weten'. Ook dit pad moet de zorgverlener kunnen meevolgen. Psychosociale begeleiding bij ernstig zieken is dus niet alleen een kunde, maar is ook een beetje een kunst; zoals kunst zich niet in één expressie laat vatten, zo is er niet zoiets als één goede manier van begeleiding. ${ }^{6}$ 


\section{LITERATUUR}

1 Loyd-Williams, M. Emotions and cognitions. In: Payne, S., J. Seymour \& C. Ingleton (eds.). Palliative Care Nursing. Open University Press, Berkshire, 2004.

2 Wiel, H. van der, A. Kooij \& B. Garssen. Verwerken, is erbij te helpen? In: Haes, J. de, L. van Weezel \& R. Sanderman (red.). Psychologische patiëntenzorg in de oncologie. Van Gorcum, Assen, 2001.

3 www.nccn.org/professionals/physician_gls/f_guidelines.asp.

4 Bauwens, S. Angst. In: Spijker, G. \& B. Laarman (red.). De praktijk van palliatieve zorg. Bohn Stafleu van Loghum, Houten, 2000.

5 Landelijke richtlijnen palliatieve zorg, Pijn. VIKC, Utrecht, 2009. www.oncoline.nl.

6 Vachon, L. Emotional issues in palliative medicine. In: Doyle, D., G. Hanks, N. Cherny \& K. Calman (eds.). Oxford Textbook of Palliative Medicine. Oxford University Press, Oxford. 2005.

7 Diagnostic Criteria from DSM-IV, American Psychiatric Association, Washington DC, 2005.

8 Landelijke richtlijnen palliatieve zorg, Depressie, VIKC, Utrecht, 2009. www.oncoline.nl.

9 Greer, S. \& M. Watson. Mental adjustment to cancer: its measurement and prognostic importance. Cancer Surveys, 1987, 6, 439-453.

10 Cancer pain relief and palliative care. WHO Technical report Series. World Health Organization, Geneva, 1990.

11 Faulkner, A. \& P. Maguire. Talking to Cancer Patients. Oxford University Press, Oxford, 1994.

12 Seymour, J. 'What's in a name?' In: Payne, S., J. Seymour \& C. Ingleton (eds.). Palliative Care Nursing. Open University Press, Berkshire, 2004.

13 Walsh, K. \& I. Kowano. Nurses' and patients' perceptions of dignity. International Journal of Nursing Practice, 2002, 8, 143-151. 


\subsection{SPIRITUELE ZORG}

\section{Marinus van den Berg}

'Het is niet wat je denkt ...' Navraag onder verzorgenden, verpleegkundigen en artsen leert ons dat het begrip spirituele zorg niet direct sexy is. Het roept zeer verschillende gevoelens en gedachten op. Die variëren van zweverig, eng, vaag tot mooi en aantrekkelijk. Het begrip kan afstoten en aantrekken. Er wordt aan verschillende thema's gedacht, zoals geloof, kerk, meer dan het zichtbare, religie, maar ook wel aan aandacht voor het niet-zichtbare. Er kan aan God worden gedacht, maar ook aan Allah of Boeddha. Voor de een is het een religieus geladen begrip en voor een ander is het dat niet. Er zijn er ook die denken aan waxinelichtjes, huisaltaren, wierook, geuren en sfeer. Het lijkt bijna een onwerkbaar begrip. Sommigen zien spirituele zorg als een taak van een geestelijk verzorger, maar anderen zien wel dat het ook tot de taken van henzelf kan horen als verpleegkundige of als arts. Ze zien ook dat er spirituele vragen op hun weg komen tijdens het werk. Daarbij dringt zich de vraag op of spirituele zorg vooral een zaak is van functies en taken, of dat er nog wat meer gezegd kan worden. Wat is er bijvoorbeeld te zeggen over de spiritualiteit van de zorgverlener zelf of over de spiritualiteit van een huis, een familie, een dorp, een instelling of een hospice. Welke geest tref je daar aan? Die van een wachtkamer of die van huiselijke warmte waar een goede ontvangst bij hoort?

\subsubsection{Het begrip spirituele zorg}

Wie iets over spirituele zorg wil schrijven, staat voor de taak om te zeggen wat hij onder dit begrip verstaat. Er zijn verscheidene pogingen gedaan, zoals in de Richtlijn Spirituele zorg die op verzoek van het kenniscentrum Agora momenteel ontwikkeld wordt.. In de Engelstalige definitie van de Wereldgezondheidsorganisatie wordt gesproken over spirituality als het gaat over de spirituele zorg. ${ }^{2}$ Sommigen spreken over het vierde gebied. Het lichamelijke, psychische en sociale zijn dan de eerste drie gebieden. Ik zou liever willen spreken over de spirituele dimensie die in iedere vorm van zorg steeds mee- en doorklinkt. Dit is een wat minder uitsluitend taakgerichte benadering. Spiritualiteit speelt op alle gebieden. Zo kan de een bij het wassen aandacht hebben voor het sluiten van de gordijnen, omdat zij beseft dat patiënten niet te kijk willen liggen, terwijl de ander hier geen aandacht voor heeft. De ene patiënt heeft hiermee geen problemen, maar een ander juist wel. ledere zorgverlener en iedere zorgvrager hebben een eigen spiritualiteit, ook als het gaat om het lichaam en de omgang daarmee. Het gaat er dus niet alleen om wat je doet, je taak, rol en functie, maar ook om hoe je doet wat je doet, en daarmee gaat het ook om wie je bent, wie je geworden bent en wie je aan het worden bent. Of als we over de patiënten spreken dan gaat het niet alleen om de vraag wat hun ziekte is, wat hun levensverhaal is, hoe hun sociale netwerk eruitziet, hoe hun psychische gesteldheid, hoe hun intellectuele 
en emotionele intelligentie is, maar ook hoe zij in het leven staan en stonden, hun leven en hun naderende sterven beschouwen en daarmee omgaan. Welke normen en waarden waren en zijn in hun leven bepalend geweest en waren die steunend of storend?

Elke mens is dus iemand, uniek en onherhaalbaar, en het getuigt van arrogantie te zeggen dat een ander niets is of nergens toe doet. Dat verhindert om te zien wat iemands verlangen, iemands streven, iemands doen en laten was en is. Dat verhindert iemands hoop te zien en hoe iemand zin aan zijn leven heeft gegeven en nog geeft. Dat verhindert te zien aan wie en wat iemand steun en houvast heeft en wat iemand heeft geïnspireerd, waar hij of zij warm voor liep en nog warm voor loopt. Het verhindert om te zien wat iemand innerlijke ruimte gaf of juist beklemde. Het verhindert te zien waar iemand misschien aan of onder geleden heeft, hoe iemand zichzelf en anderen zag, of iemand zich ook echt gezien voelt of dat iemand steeds moest zijn wat anderen van hem dachten. Niet zelden is een mens iemand met meerdere gezichten en is het de vraag wat iemands echte gezicht is. Het Engelse woord spirituality wordt vertaald met spiritualiteit. Daarin zit het Latijnse woord geest. Spiritualiteit duidt ook op begeestering, bezieling en betrokkenheid. Als zorg sleurzorg wordt, dan is de aandacht, de betrokkenheid eruit. Dan moet die soms worden afgestoft om vernieuwd te worden. Spiritualiteit is in iedere mens op een eigen wijze aanwezig en ze laat zich niet in het doosje van een definitie doen. 'Het is niet wat je denkt ...'

Hopelijk heeft deze eerste verkenning de lezer niet alleen nieuwsgierig gemaakt, maar ook aan het denken gezet over zijn of haar eigen gedachten, beelden en gevoelens als het gaat om spirituele zorg. Hopelijk heeft het duidelijker gemaakt dat het ook gaat om het gewone van alledag en hoe dat gedaan wordt. Verdere vragen, stellingen, gedachten om met elkaar op de werkvloer aan de praat te raken over spirituele zorg zijn te vinden in het boek $A B C$ voor spiritualiteit in de zorg. ${ }^{3}$

Hieronder gaan we verder in op het gebied van de spiritualiteit in de palliatieve zorg. Er wordt stilgestaan bij de ander, die gast, patiënt, cliënt is, en bij zijn of haar naasten. Ziek worden en gaan sterven is een persoonlijk, individueel, maar ook een relationeel, familiaal en sociaal gebeuren. Een voor velen belangrijke levensgebeurtenis. Er verandert voor veel mensen meer dan vaak vermoed wordt. Vervolgens zullen we ook stilstaan bij de zorgverlener en bij spiritualiteit op en in het werk. Dit gaat verder dan in de overigens waardevolle Richtlijn Spirituele zorg.

\subsubsection{De patiënt}

Moet men spreken - en dat is ook een spirituele vraag - van een patiënt, een gast, een cliënt of een bewoner? Velen vinden patiënt te medisch, maar in het woord patiënt zit het woord lijden en het woord geduld (patience). Wie ziek wordt, lijdt lichamelijk maar ook vaak geestelijk, psychisch en sociaal. Wie ziek wordt, moet vaak wachten, geduld hebben, ervaart angst, onzekerheid. Zijn of haar vertrouwde wereld wankelt. 
Hij of zij moet leren vragen en leren omgaan met afhankelijkheid. Ziek zijn kan als vernederend worden ervaren, maar kan ook een oefening in nederigheid worden. Ziek zijn kan iemand ook tot een dankbaarder mens maken. Ziekte zet iemand stil en brengt hem van snelle tijd in vertraagde tijd. Ziekte kan tot nadenken stemmen over wie je bent en wat de waarde van je leven is. Allerlei vragen, die we ook wel levensvragen en bestaansvragen noemen, kunnen zich aandienen. Vragen naar het waarom en waartoe. Iemand kan lijden onder deze vragen omdat er niet zomaar een antwoord voorhanden is. Ze horen niet tot het gebied van het oplosbare. Er bestaat geen paracetamol voor. Soms wel een inlevend luisterend oor, maar dat is er niet altijd. Ziekte brengt ook eenzaamheid en woelige nachten mee, opzien tegen de dag. Spirituele zorg is aandacht voor deze vragen. Iemand kan zelf die aandacht vragen, tijdens het wassen, tijdens een onderzoek, een hulp- of zorgcontact. Die vragen zitten vaak verborgen in opmerkingen of andere vragen. Een vraag of er een bezoekuur is, kan duiden op een behoefte aan de aanwezigheid van een naaste, een familielid of vriend. Onrust in de nacht of vaak bellen kan duiden op innerlijke onrust en behoefte aan aandacht. Achter veel vragen en opmerkingen zit vaak iets anders. Van zorg- en hulpverleners mag dan ook verwacht worden dat zij niet alleen taakgericht bekwaam zijn en goede deskundige zorg geven, maar dat zij ook luistervaardig zijn, de innerlijke bereidheid hebben om te luisteren naar de vragen achter de vragen. Niet alleen bereidheid is nodig, maar ook het vermogen om op te merken. Goed kijken en goede open vragen stellen is even waardevol als meelevend luisteren. Wie oog en oor heeft voor al die innerlijke vragen zal ook opmerken dat er soms meer tijd nodig is, dat er ook een andere kundigheid nodig is. Dat kan de kunde van een psycholoog zijn of van een geestelijk verzorger. Het hoort ook tot de taak van een verplegende om te kunnen verwijzen en te weten wat andere hulpverleners kunnen bieden en/of betekenen.

De levensvragen van een patiënt - die in zekere zin ook cliënt is, een klant met terechte verwachtingen en eisen, vooral op het materiële gebied, zoals: 'Is er op tijd een geschikte matras beschikbaar om doorliggen te voorkomen?' - kunnen verschillend gekleurd zijn. Die kleur staat niet los van iemands levensbeschouwelijke geschiedenis, zijn autobiografie. Die gaat over de vragen: Wie ben je van huis uit? Wat is je persoonlijke, maar ook je sociale en culturele identiteit? Er is steeds vaker aandacht voor het multiculturele en multireligieuze aspect van de zorg en dus ook van de spirituele zorg. Wie in contact komt met een in Turkije geboren patiënt zal al snel merken dat hij of zij anders met zijn ziek-zijn omgaat dan wie in contact treedt met een rooms-katholieke West-Vlaamse vlasboer uit de streek van Ieper of een Friese veeboer uit de buurt van Dokkum die opgevoed is en zich thuis voelt in de Nederlandse Hervormde Kerk. Ieder brengt zijn eigen achtergrond, gewoontes en gebruiken mee en de wijze waarop die een persoon hebben gevormd of ook wel eens misvormd. Wie het veelgelezen boek Knielen op een bed violen van Jan Siebelink heeft gelezen, treft daar een zeer specifieke sfeer aan rondom het sterven, heel anders dan bijvoorbeeld in het beroemde boek De dood van Ivan Iljitsj van Lev Tolstoj.4,5 
De persoonlijke levensbeschouwing heeft ook invloed op de grote ethische vragen zoals doorgaan en stoppen van behandeling, de toelaatbaarheid van levensbeëindiging, de visie op zelfdoding, maar ook op wat iemand verwacht na zijn sterven. Die levensbeschouwing heeft ook gevolgen voor wat iemand naast medicatie nodig heeft. Meditatie en iemand die bemiddelt, die luistert, die met je praat en reflecteert of stil is, expliciet voor jou tijd heeft en beschikbaar is, kunnen van even grote waarde zijn. Waar deze aandacht voor de spirituele zorg verwaarloosd of onderschat wordt, daar is de kwaliteit van de zorg in het geding.

Een patiënt die aan een verplegende vroeg: 'Hoe is hier de kerkdienst?' kreeg als antwoord: 'Dat weet ik niet, daar bemoei ik me niet mee, ik geloof niet.' Een dergelijk antwoord dat geen antwoord is, is driemaal fout en is slechte patiëntenzorg.

\subsubsection{De naasten}

Spirituele zorg is ook aandacht voor de naasten. Niet alleen voor hun behoefte aan informatie en allerlei materiële behoeften, maar ook aandacht voor hun beleving, hun levensvragen. Ook hun leven is in transitie, in crisis. Verpleegkundigen en verzorgenden hebben een belangrijke rol ten aanzien van de naasten in deze periode. Naasten zien niet alleen wat je doet, maar ook hoe je het doet. Naasten willen niet alleen goedbedoeld horen: 'Denkt $u$ ook aan uzelf', maar willen soms kunnen vertellen hoe het voor ze is. Juist in de laatste dagen en uren is denken aan de ander, er zijn voor die ander verbonden met denken aan zichzelf. Er is ook een sterven in de naasten zelf gaande ... een scheiden dat zeer veel pijn kan doen. Spirituele zorg is hier aandacht hebben voor de innerlijke beleving, maar ook de bejegening, de aandacht, soms een arm om iemand heen.

Sterven is een familiegebeuren. Elke familie heeft haar eigen spiritualiteit. Die kan ook chaotisch zijn, getekend door conflicten en vervreemding. Niet oordelen, je grenzen kennen en ontdekken wat je wel en niet kunt betekenen is juist hier een kunst en eveneens een vorm van spirituele zorg. Ieder familielid ervaart het sterven op een eigen wijze. Ook hier speelt ieders eigen levensverhaal met de eigen levensgebeurtenissen een centrale rol. Dé familie bestaat niet, maar wel deze zoon, deze dochter, deze zus, deze broer, deze echtgenote, deze neef, deze tante, deze opa, deze oma ...

\subsubsection{De zorgverlener}

De zorgverlener is altijd een andere. Zijn of haar leven ziet er anders uit, vaak heeft hij of zij een andere leeftijd. De zorgverlener kan zin ervaren in het geven van goede zorg. In de palliatieve zorg werken velen met passie omdat ze er meer tijd voor mensen hebben of maken. De zorgverlener ontmoet mensen die op vele gebieden juist zin aan het verliezen zijn. In het leven van zorgvragers zien de zingebieden van intimiteit, arbeid, ontspanning en levensbeschouwing er vaak heel anders uit dan in het 
leven van de zorggevers. Waar de een aan het opbouwen is, ervaart de ander verlies en afbraak. Zo kunnen er grote verschillen zijn als het gaat om levensbeschouwing. Wat voor de een belangrijk is, zoals geloof en naar de kerkdienst kunnen gaan, kan voor een ander niets betekenen. Een zorgverlener kan zich losgemaakt hebben uit een voor hem of haar verstikkend godsdienstig milieu, of een zorgverlener voor wie geloof belangrijk en waardevol is komt in contact met een patiënt die zegt niets te geloven, die weinig waardering heeft voor al die verschillende godsdiensten en voor wie de dood het einde van alles is. Spirituele zorg vraagt om het vermogen te onderscheiden. Er is respect en inzicht nodig in je eigen weg, je eigen ontwikkeling en groei, je eigen normen en waarden om het onderscheid te maken in wat de weg van de ander is. De vraag is dan wat de ander nodig heeft en als ik niet kan geven wat die ander nodig heeft, wie kan dat dan wel.

\subsubsection{Spirituele omgeving}

Wie in de thuiszorg werkt en op een dag op meerdere adressen komt, kan getroffen worden door de verschillende inrichtingen, de andere sferen op die adressen. De alleenwonende oude hoogleraar die nog zo lang mogelijk aan zijn computer wil werken of de jonge vader die zijn kinderen niet ouder zal zien worden. Alles kan er anders voelen, alle kamers en alle dingen. Spirituele zorg is hier je verplaatsen in telkens andere levens, met andere normen en waarden, gewoontes en gevoeligheden. Men spreekt ook van sensitiviteiten. In dat woord zit het woord 'sens' dat onder meer richting, zin en lust betekent. Ook wie in een instelling, een hospice of een palliatief centrum werkt, wordt getroffen door die verschillen. Wie daar oog voor heeft, beseft ook scherper zelf te gast te zijn bij de ander die soms gast wordt genoemd. Je komt in andermans intimiteit. Je komt op andermans leefgebied dat nu zijn of haar laatste leefgebied is geworden. Je kijkt door het raam dat voor de ander het laatste raam is geworden.

Het valt ook op hoe verschillend sferen kunnen zijn in instellingen. Verschil in ontvangst, verschil in begroet worden of niet, verschil in inrichting. Bij de een heerst het anonieme, het zakelijke en functionele en in de andere is er veel meer een warm bijna-thuis-gevoel. Je ziet en merkt het vaak aan details. Sommige mensen vertellen dat ze in een ziekenhuis niet durfden te huilen omdat alles het gevoel uitstraalde dat dat ongewenst was. De sfeer in een instelling wordt niet alleen gemaakt door de dingen, door de kleuren, door de ligging, maar evenzeer door de mensen die er werken, die er komen. Wat stralen ze uit? Zijn zij zich dat bewust? Een man die thuis zorg ontving, beschreef de verschillen als volgt: 'De een die hier binnenkomt roept al in de gang hoe het hier is, met een stem alsof je op een vakantieadres bent, en een ander beseft in jouw huis en aan jouw bed te komen. Die kijkt eerst, geeft je een hand en ziet soms dat de vraag hoe het is echt belangrijk is, zodat je kunt zeggen hoe het echt is.' 
Je komt in andermans leefgebied en aan de dingen van een ander: foto's, bloemen, kleding en noem maar op. De een heeft behoefte aan rust en stilte en bij de ander staat altijd de televisie aan of is er luide muziek. Het zegt ook iets over de zorgverlener, hoe die met al die verschillen omgaat. Onbewust en bewust is ook zijn of haar spiritualiteit in het geding. Soms ziet een ander aan zijn gezicht dat hij iets lijkt te waarderen of juist niet. Je doet nooit alleen je taak, maar je doet ook altijd zelf mee. Zo doet ook een sfeer, de spiritualiteit van een instelling mee in het geheel van de zorg. Vandaar het belang van voldoende aandacht voor the 'spirituality of buildings and institutions'. Hier liggen ook veel aandachtspunten voor het management en de spiritualiteit van het management, een aspect dat hier slechts aangestipt is.

\subsubsection{Conclusie}

'Het is niet wat je denkt ...' Het is misschien wel meer wat je voelt. Voor de een is dat vaag en niet evidence based en voor de ander is het een verademing. Voor de een is spirituele zorg een soort ver-van-mijn-bedshow en voor een ander is het concreet, dichtbij het leven en werk van elke dag. In deze paragraaf hebben we niet zozeer een definitie aangereikt of allerlei dingen om te doen of te laten, ook niet allerlei weetjes, die overigens heel belangrijk kunnen zijn. Spirituele zorg is ook een zaak van kennis en niet alleen van kunst en kunde. Spirituele zorg is niet iets aparts, maar een dimensie die steeds meedoet in wat en hoe je doet, kijkt, reageert, luistert of net niet luistert en ziet wat voor de ander van belang is.

\section{LITERATUUR}

1 Palliatieve zorg: richtlijnen voor de praktijk. VIKC, Utrecht, 2010. www.pallialine.nl.

2 Definitie palliatieve zorg. WHO, 2002. www.palliatievezorg.nl/page_867.html.

3 Berg, M. van den. $A B C$ voor spiritualiteit in de zorg. Ten Have, Kampen, 2008.

4 Siebelink, J., Knielen op een bed violen. De Bezige Bij, Amsterdam, 2005.

5 Tolstoj, L. De dood van Ivan Iljitsj. Meulenhoff, Amsterdam, 2007. 


\section{4 ZORG ROND HET STERVEN}

\section{Bart Van den Eynden en Annick Vanderoost}

Sterven maakt onlosmakelijk deel uit van elk leven, het zou een respectvolle en vredevolle periode moeten zijn. Het is een uniek en individueel proces, dat elk van ons ooit slechts eenmaal meemaakt. De manier waarop mensen overlijden laat vaak een diepe indruk na op de familie en de naasten. De stervende heeft in deze erg kwetsbare periode van het leven recht op een nauwgezette symptoomcontrole en psychosociale ondersteuning, en de familie op voldoende begeleiding. Zorgen voor een 'goede dood' voor alle stervenden en hun naasten blijft daarom een uitdaging, niet alleen voor artsen, verpleegkundigen en andere hulpverleners, maar ook voor de hele maatschappij.

\subsubsection{De diagnose van het sterven}

Het spreekt vanzelf dat het stellen van de diagnose van sterven essentieel is om in deze fase tot goede zorg te komen. In een ziekenhuisomgeving met een cultuur gericht op genezing is het vaak moeilijk om de keten van procedures, onderzoeken en behandelingen een halt toe te roepen. Soms bestaat er weerstand om te erkennen dat de patiënt gaat sterven zolang er ook maar een sprankje hoop op genezing blijft. Toch is het beter om, indien herstel uitblijft en weinig waarschijnlijk wordt, dit te bespreken met patiënt en familie, eerder dan valse hoop te blijven voeden. Er bestaan geen goede instrumenten die het mogelijk maken om de diagnose sterven te stellen. Soms kunnen veranderingen in de Palliative Performance Scale wel een aanduiding geven dat de dood nadert. ${ }^{1}$ Het inschatten van het sterven blijft dus hoofdzakelijk een klinische vaardigheid, waarbij verpleegkundigen de artsen sterk kunnen helpen door goede observaties en evaluaties. Bij kankerpatiënten is een geleidelijke, gestage achteruitgang de regel, alhoewel het niet zelden gebeurt dat ook bij hen verschillende levensbedreigende periodes de finale stervensfase voorafgaan. Bij niet-oncologische, mogelijk fataal eindigende aandoeningen, zoals neurologische aandoeningen, hartfalen of nierinsufficiëntie, is het inschatten van het begin van de stervensfase zo mogelijk nog moeilijker, dit vanwege het verschillend ziekteverloop. ${ }^{1}$

De volgende tekenen en symptomen kunnen helpen om de diagnose 'sterven' te stellen:

- snelle achteruitgang dag-na-dag of zelfs vlugger als gevolg van progressie van de eigenlijke ongeneeslijke ziekte of als gevolg van een irreversibele complicatie van de ziekte;

= de patiënt geeft zelf te kennen dat hij/zij aan het sterven is;

- achteruitgang van de algemene toestand, slaperigheid of comateuze toestand;

- bedlegerigheid; 
III nog slechts de mogelijkheid om heel kleine hoeveelheden voedsel en drank tot zich te nemen en moeilijkheden om nog langer de orale medicatie te nemen;

iiv een veranderd ademhalingspatroon;

w het optreden van perifere cyanose en het koud aanvoelen van handen en voeten.

Toename van pijn of kortademigheid is eerder ongewoon bij patiënten bij wie de symptomen tot dan goed onder controle waren. ${ }^{2}$ De mediaan van het begin van de stervensfase is 23 uur voor het intreden van de dood, met een variatie van enkele uren tot verschillende dagen. ${ }^{3}$

\subsubsection{Tijd voor finale bijsturing}

Het is belangrijk dat alle leden van het multidisciplinaire team rond de patiënt akkoord gaan met de vaststelling dat het overlijden imminent is, dus nog enkele uren tot dagen zal uitblijven. Als er geen overeenstemming is tussen de teamleden, dan zullen tegenstrijdige boodschappen en zorgdoelen die tegengesteld zijn, tot een slecht, mank lopend beleid en een verwarrende communicatie leiden. Als het gehele team inderdaad met deze diagnose instemt, dan moet dit gecommuniceerd worden met de patiënt, indien nog mogelijk, en met de familie. Vervolgens kan dan heel het beleid geheroriënteerd worden. De terminale fase is immers de cruciale periode om nog een aantal aspecten bij te sturen en te regelen.

n' 'Nutteloze' medicatie stopzetten. Als dit nog niet gebeurd is, is het moment waarop de patiënt achteruitgaat het ogenblik waarop het medicatieschema drastisch teruggeschroefd en vereenvoudigd kan worden. Bovendien kan de patiënt meestal toch deze medicatie niet meer slikken.

- Overblijvende medicatie zo veel mogelijk langs geschikte toegangswegen toedienen. Meestal zal hiervoor de subcutane weg gekozen worden, maar ook de sublinguale toediening kan een geschikt alternatief zijn.

- 'Doorbraakmedicatie' (ook 'rescuemedicatie' genoemd) voorzien. Morfine, scopolamine en midazolam zijn voorbeelden van middelen die thuis of op de afdeling waar de patiënt verblijft aanwezig dienen te zijn. Voor de verpleging dienen orders te worden geschreven waardoor die in staat is om wanneer de patiënt bijvoorbeeld doorbraakpijn heeft, snel in te grijpen.

- Lichamelijke symptomen zo veel mogelijk onder controle krijgen. Sociale en psychische aanpassingen en afscheid nemen zijn alleen mogelijk wanneer er geen ernstige pijn, geen braken of geen kortademigheid aanwezig is. Hierbij is ook goede en geregelde mondzorg heel belangrijk, waarbij men de familie kan betrekken.

w Voldoende en aangepaste uitleg en informatie geven. Onvoldoende informatieverstrekking is niet zelden de oorzaak van problemen. Net zoals pijnmedicatie 
moet ook deze informatie al naargelang de persoon, de situatie, het verloop 'getitreerd' worden. Hierbij is zorgvuldige uitleg over alle maatregelen die worden voorgesteld heel belangrijk (bijvoorbeeld de reden van het staken van het nemen van vitale parameters zoals bloeddruk, van parenterale vochttoediening).

- Anticiperen op te verwachten situaties en problemen. Het is uiteraard niet mogelijk om op elke crisissituatie te anticiperen, maar vooraf plannen is hoe dan ook essentieel, bijvoorbeeld het voorzien van scopolamine tegen bronchiale secreties waarvan patiënten in de terminale fase vaak last hebben.

- Geven maar ook aanvaarden van ondersteuning en begeleiding. Het is de opdracht van de zorgverlener om hulp en steun te verlenen, maar anderzijds moeten we ook bereid zijn om zelf hulp, advies en ondersteuning te vragen en te aanvaarden in geval van onzekere of moeilijke situaties en problemen.

- Realistische zorgdoelen stellen. Zorgdoelen veranderen wanneer de patiënt sterk achteruitgaat. Anderzijds kunnen deze ook de hoop voeden, al gaat het dan enkel om het behouden van zo veel mogelijk comfort. Men zal ook DNR-codes (do not resuscitate) dienen af te spreken, als dit nog niet gebeurd is.

w Aanbieden van spirituele en religieuze zorg en begeleiding wanneer hierom gevraagd wordt. Vraag aan de patiënt, partner of familie of een gesprek met pastor, priester of moreel consulent gewenst is.

* Partner, familie en mantelzorg uitleg geven over de veranderingen die plaatsgrijpen of zullen komen. Ook de omgeving heeft recht op evenveel (of even weinig) informatie als ze nodig heeft, op voorwaarde dat de patiënt hiermee instemt of in het verleden ingestemd heeft.

iv Help om al deze veranderingen ook te begrijpen en ze een plaats te geven. De veranderingen die in de terminale fase plaatsvinden, boezemen meestal heel wat angst in. Het kan daarom toch geruststellend zijn uitleg te krijgen over het natuurlijk verloop van het stervensproces.

w Andere leden van het team informeren.

- Aangepaste en waardige omgeving creëren. Een comfortabele omgeving, al naargelang de wensen van de patiënt: veel licht of juist gedempt, stil of met muziek, foto's op het kastje naast het bed, kaarsen, aromageuren en dergelijke.

In Het moment van overlijden zo goed mogelijk voorspellen. Voor een aantal patiënten, families en zorgverleners kan dit een heel waardevolle tijd zijn om het te hebben over bepaalde onderwerpen, zoals het regelen van de begrafenis of orgaandonatie.

\subsubsection{Symptoombeleid}

Onvoldoende gecontroleerde pijn, kortademigheid en rusteloosheid behoren tot de meest voorkomende redenen van fysiek lijden tijdens de stervensfase. Verschillende behandelingen kunnen dan aangewend worden. Het sederen van palliatieve 
patiënten, palliatieve sedatie, mag slechts overwogen worden als andere behandelingen tekortschieten en de symptomen refractair blijken te zijn. En ook dan zal men starten met lage doses sedativa (en geen morfine of andere opioïden) en afhankelijk van patiënt en situatie geleidelijk optitreren. ${ }^{4-6}$

- Vochtige, reutelende en lawaaierige ademhaling. De retentie van secreties in de luchtwegen leidt in de stervensfase niet zelden tot 'terminale' of 'doodsreutel'. Dit kan (maar hoeft niet noodzakelijk) angst veroorzaken bij familie en zorgverleners. Veranderen van houding volstaat bij een heel aantal patiënten om de bronchiale secreties te verminderen. Lukt dit niet, dan beschikken we over scopolamine of andere anticholinergica. Bij ongeveer de helft van de patiënten vermindert hiermee de terminale reutel.

in Urine-incontinentie. Een aantal patiënten hebben tijdens hun ziekteverloop last van urine-incontinentie. Veelal zal dit afnemen wanneer de renale functie van de patiënt vermindert tijdens de terminale fase. Zo niet, dan zal men zijn toevlucht blijven nemen tot pampers, condoomkatheters (mannen) of blaaskatheters, uiteraard na overleg met patiënt en familie.

w Pijn. De pijn is meestal goed onder controle te brengen met het bestaande opioïdregime. Tijdens de laatste 48 uur zien we dat bij 13\% van de patiënten de dosis analgetica zelfs verminderd kan worden, bij $44 \%$ dient deze wel te worden verhoogd en bij $48 \%$ kan ze onveranderd blijven. Wel zal men veelal de toedieningsweg dienen aan te passen zodra de patiënt geen orale medicatie meer kan innemen. Toch kunnen heel wat omstandigheden en comorbiditeiten bijdragen tot extra pijn boven op de ziektegerelateerde pijn in deze fase van het verloop: urineretentie, constipatie, ongemakkelijke en niet-comfortabele houding, infectie en decubituswonden. Ernstige, niet-verlichte pijn moet absoluut vermeden worden. Incidentele pijn kan verlicht worden door het geven van een analgetische dosis voor het verleggen, draaien of verzorgen van de patiënt (zie ook paragraaf 4.1).

" Kortademigheid. Dyspnoe is de perceptie, het subjectieve beleven van de patiënt van kortademigheid. Veel van de behandelingen die voorheen reeds gegeven werden vanwege kortademigheid, zijn nu niet langer bruikbaar (bijvoorbeeld dosisaerosolen). Overweeg hier in eerste instantie conservatieve maatregelen zoals de houding van de patiënt, het zorgen voor een 'frisse wind' (ventilator, open venster), zuurstoftoediening, relaxatie en geruststellende uitleg en nabijheid. Medicamenteus kan (extra) morfine worden overwogen en het geven van een benzodiazepine om de vicieuze cirkel die leidt tot een 'respiratory panic attack', te doorbreken.

II Nausea en braken. Anti-emetica kunnen gegeven blijven worden langs subcutane weg via een continue spuitdrijver (een port-a-cath). Een nasogastrische sonde kan een bepaalde hinder veroorzaken maar is soms toch nodig voor aspiratie 
van grote hoeveelheden vocht die anders regelmatig opgebraakt zouden worden. Eventueel kunnen ook suppositoria worden gebruikt. Kleine slokjes water en goede mondzorg zorgen voor comfort.

= Zweten. Ook hier weer zullen conservatieve maatregelen vaak voldoende soelaas brengen. Houd de patiënt koel, laat regelmatig het bedlinnen verschonen, vraag de familie voor katoenen nachtkleding te zorgen. Het is ook een uitgelezen kans om de familie daadwerkelijk bij de zorg te betrekken door de patiënt regelmatig te verfrissen via een koud washandje of doekje.

- Onwillekeurige, ongecontroleerde bewegingen. Het zien optreden van spiertrekkingen is voor de familie vaak stressvol; de patiënt zelf - meestal zó ziek of comateus - is er zich meestal niet van bewust. Vaak gebeurt dit ten gevolge van een te hoge opioïdconcentratie (door de nierinsufficiëntie), uremie, veranderingen in de neurologische toestand, of het toedienen (bijvoorbeeld neuroleptica of dopamineantagonisten) of juist stoppen (bijvoorbeeld benzodiazepinen, barbituraten, anticonvulsiva) van bepaalde medicamenten. Men dient dus te overwegen om de dosis opioild te reduceren of eventueel opioidrotatie toe te passen (het overschakelen op een ander opioïd). Verder zal men nogmaals het gehele medicatieschema dienen te heroverwegen. Vaak zal sedatie met continue subcutane toediening van midazolam nodig zijn.

m Kunstmatige vochttoediening. Het al dan niet toedienen van extra vocht langs kunstmatige weg (intraveneuze of subcutane hydratatie) is een emotioneel geladen, controversieel onderwerp. Meestal wegen de voordelen van vochttoediening (zoals minder delirium, minder infecties) niet op tegen de nadelen (meer kans op reutelende ademhaling, meer oedemen, meer gastro-intestinale secreties, en zo meer). Belangrijk is dat dit, zo mogelijk, vooraf met patiënt en familie zorgvuldig besproken wordt.

* Rusteloosheid en verwardheid. Naast rustgevende en structurerende maatregelen kan men gebruikmaken van neuroleptica (bijvoorbeeld etumine, chloorpromazine). In heel uitzonderlijke omstandigheden kan men zijn toevlucht nemen tot benzodiazepinen.

a Palliatieve sedatie. In geval van refractaire symptomen kan men genoodzaakt zijn, na zorgvuldig afwegen en overleg met patiënt, familie en team, het bewustzijn van de patiënt zodanig te verminderen dat deze geen symptoomdistress meer ervaart. Door de sedatie slaapt de patiënt door het verdere stervensproces en beleeft dit dus niet meer bewust. Op die manier wil men het comfort van de patiënt tijdens de stervensfase verbeteren. Het spreekt vanzelf dat patiënt en familie moeten weten dat geen verbale communicatie meer mogelijk zal zijn. Diverse instanties, lokaal maar ook internationaal zoals in Nederland of door de European Association of Palliative Care, hebben richtlijnen en stappenplannen ontwikkeld die bijdragen tot een grote zorgvuldigheid bij het beslissingsproces 
tot palliatieve sedatie. Voor palliatieve sedatie zal men veel gebruikmaken van midazolam, continu toegediend via cen subcutane spuitdrijver. Ook fenobarbital intraveneus wordt soms gebruikt.

- Urgente situaties tijdens de stervensfase. In geval van acuut verstikkingsgevaar is onmiddellijke sedatie een absolute noodzaak. Ook hiervoor zal men midazolam gebruiken. Bij een massieve bloeding is er nauwelijks tijd genoeg om de patiënt af te zonderen (bijvoorbeeld met een gordijn). Als men de mogelijkheid had op het gebeuren te anticiperen, dan kan men ervoor zorgen dat er donkere handdoeken klaarliggen zodat het massieve bloedverlies wat minder choquerend lijkt. Ook midazolam dient bij de hand te worden gehouden voor onmiddellijke sedatie. Ook het optreden van convulsies vergt een urgente tussenkomst met het toedienen van midazolam, diazepam of rivotril.

\subsubsection{Psychosociale zorg}

De meeste wilsbekwame patiënten weten hoe ernstig ziek ze zijn, en dat ze zullen sterven. Hopelijk is er ook nog voldoende tijd om terug te kijken en hun levensbalans te maken, maar ook om in de toekomst te kijken, om na te denken wat zij nog verwachten en hoe zij het beloop van hun stervensfase zelf zien. De meeste patiënten wensen geruststelling dat zij niet alleen gelaten zullen worden, dat zij niet zullen lijden en dat zij geen last (zullen) betekenen voor diegenen die voor hen zorgen. Vóor de laatste dagen en uren ingaan zal men ook zo veel mogelijk consensus trachten te bereiken tussen patiënt, mantelzorg en professionals waar de patiënt zal verblijven tijdens de eigenlijke stervensfase (wanneer dit in het kader van vroegtijdige zorgplanning eerder nog niet is gebeurd). Het doel moet zijn om een sereen kwaliteitsvol sterven mogelijk te maken, met een adequaat symptoommanagement, zo veel mogelijk daar waar de patiënt het verkiest. Binnen het holistisch palliatief beleid vormt ook het inspelen op en omgaan met de emotionele behoeften van de familie een belangrijke doelstelling: deze moeten dus geïdentificeerd, erkend en begeleid worden. De emotionele behoeften van de patiënt, zijn familie en zijn geliefden moeten continu geëvalueerd en geherevalueerd worden; dit betekent veelal dat de verschillende leden van het multidisciplinaire team (zoals sociaal werker, pastor of moreel consulent) ingeschakeld worden (zie ook paragraaf 4.2).

\subsubsection{De stervensfase zelf}

- Wat gebeurt er met de patiënt? Bij de meeste patiënten met een chronisch gevorderde ziekte ziet men een voortdurend afnemen en uitvallen van de activiteiten van de verschillende lichaamssystemen. Zelfs bij chronisch hartfalen en COPD is plots, dramatisch sterven eerder ongewoon. In feite kan men stellen dat op het einde het eerder gaat om een zacht 'uitdoven' van het leven dan het plots optreden van de dood. 
= Hoe beleven de familie en de zorgverleners dit? Voor sommigen komen de tranen vanzelf, anderen voelen zich alsof ze 'uitgedroogd' zijn en geen tranen (meer) hebben. Sommigen ervaren de dringende behoefte om van alles te vertellen, heel vaak om zich op die manier te ontladen. Anderen ervaren het dan weer als een anticlimax omdat de patiënt in zekere zin reeds uren of dagen ervoor 'vertrokken' was. Weer anderen zijn zo verstijfd van verdriet en rouw dat zij zich volslagen hulpeloos en nutteloos voelen, maar dit vaak niet durven toegeven aan anderen. Sommigen herinneren zich zelfs geen namen, adressen en telefoonnummers meer. Hiermee moeten we rekening houden wanneer we informatie willen krijgen, bijvoorbeeld voor het invullen van de overlijdensakte of om andere verwanten te waarschuwen. Het kan ten slotte ook gebeuren dat de partner of een andere verwant de voorafgaande achteruitgang en overlijden van de patiënt niet kan plaatsen en reageert met shock, boosheid of woede op datgene wat voor iedereen duidelijk is. Uiterst zelden zal het hierbij gaan om echte onwetendheid wat de feiten betreft, het gaat dan bijna altijd om verwanten die de vreselijke waarheid niet onder ogen kunnen zien. In zulke gevallen is het belangrijk om gespecialiseerde hulp en ondersteuning (psycholoog, sociaal werker, pastor) in te schakelen.

w Hoe is dit voor de professionele zorgverlener? Deze momenten worden niet zelden als pijnlijk ervaren. Veel hulpverleners hebben dan ook het overweldigende gevoel om iets te gaan doen, zoals het controleren van de pols of de ademhaling, het goed leggen van een kussen of thee gaan zetten. Er bestaan hiervoor geen vaste regels, wel enkele principes die het best nageleefd kunnen worden:

- laat de familie het initiatief nemen; geef hen de kans het op hun manier te doen;

- stilte kan pijnlijk zijn, maar is goed op het juiste moment, op de juiste plaats (woorden schieten steeds tekort, er is niets wat je kunt zeggen dat het beter zou maken ...);

- als de aanwezigen wensen te praten, praat dan mee; wensen zij in stilte aanwezig te zijn, laat hen dan met hun stilte;

- sommige aanwezigen wensen absoluut dat er wordt nagegaan of de patiënt wel echt overleden is; wacht toch enkele minuten na de laatste adem alvorens de patiënt inderdaad overleden te verklaren;

- vraag aan de aanwezigen na het overlijden of ze nog wensen te blijven, en indien dit het geval is, of ze graag alleen willen blijven.

\subsubsection{De fase na de dood}

Ook hier hebben professionele zorgverleners nog een aantal verantwoordelijkheden, zoals het helpen van de familie bij het contact opnemen met verwanten en vrienden, het navragen of er een begrafenis dan wel een crematie zal plaatsvinden, het helpen 
van de verwanten een begrafenisondernemer te kiezen, het uitleggen wat een overlijdensakte is en wat daarop genoteerd wordt. Verder kunnen er zich ook specifieke situaties voordoen, zoals het plaatsvinden van een autopsie of orgaantransplantatie, die een bijzondere aanpak en begeleiding vergen.

\subsubsection{Het Zorgpad Stervensfase}

De laatste jaren wordt er binnen de gezondheidszorg veel aandacht besteed aan het werken met klinische paden of zorgpaden. Ook om de kwaliteit van zorg en symptoomverlichting in de palliatieve terminale zorg te optimaliseren, werd er een terminaal zorgpad ontwikkeld, het Zorgpad Stervensfase, een gevalideerde vertaling van de Liverpool Integrated Care Pathway for the Dying Phase (LCP)..$^{7 n}$ Het zorgpad bestaat uit een checklist en richtlijnen voor behandeling, verzorging en begeleiding van patiënten die naar het oordeel en de verwachting van alle betrokken zorgverleners op korte termijn zullen sterven. De zorg betreft zowel de patiënt als zijn naasten. De zorg wordt beschreven in zorgdoelen, onderverdeeld in drie gerelateerde delen: de situatie bij de start van het zorgpad (deel 1), de 4- en 12-uursobservaties tijdens de zorg (deel 2) en de zorg na overlijden (deel 3). De zorgdoelen liggen vast, dus die hoeven niet voor elke patiënt individueel bepaald te worden. Toch hoeft het zorgpad geen keurslijf te zijn. Hoe men de doelen behaalt, is mede afhankelijk van de context waarbinnen gewerkt wordt. Alle acties die ondernomen worden om een zorgdoel te bereiken, worden in het zorgpad genoteerd. Per doel zijn mogelijke interventies en aandachtspunten opgenomen. Als een doel niet 'bereikt' wordt, wordt dat geregistreerd als 'anders'; bij de 4- en 12-uursobservaties zijn criteria aangegeven waarmee het al dan niet bereiken van een doel kan worden vastgesteld.

\subsubsection{Conclusie}

Iedereen heeft recht op goede zorg en begeleiding tijdens zijn stervensfase. Wanneer de diagnose van een naderende dood is gesteld, dient men eensgezind en duidelijk het beleid hierop af te stemmen. Enkele elementen hiervan zijn concrete zorgdoelen vooropstellen, onnodige medicatie stoppen, pijn en andere symptomen controleren, maar tegelijkertijd ook voldoende psychosociale zorg bieden, anticiperen en voorzien van problemen. Pijn, kortademigheid en onrust zijn de meest voorkomende fysieke symptomen tijdens het sterven. Voor deze en andere symptomen bestaan oplossingen die zo niet geheel, dan toch gedeeltelijke verlichting kunnen bieden. Voor een aantal refractaire situaties kan men zijn toevlucht nemen tot palliatieve sedatie. Aangezien palliatieve zorg vertrekt vanuit een holistisch perspectief, dient evenveel aandacht te gaan naar de emotionele, sociale en existentiële behoeften van de patiënt zodat deze op een rustige en serene manier afscheid kan nemen. Ten slotte zal men tijdens het sterven en na het overlijden aandacht blijven hebben voor de verschillende manieren waarop nabestaanden dit verwerken en hierop inspelen. Een Zorgpad Stervensfase kan helpen om de zorg in de stervensfase in goede banen te leiden en de kwaliteit ervan te optimaliseren. 


\section{LITERATUUR}

1 Ellershaw, J. \& C. Ward. Care for the dying patient: the last hours and days of life. British Medical Journal, 2003, 326, 30-34.

2 Henriksen, H., J. Riis, B. Christophersen \& C. Moe. Distress symptoms in hospice patients. Ugeskr Laeger, 1997, 1159, 6992-6996.

3 Morita, T., T. Ichiki, J. Tsunoda, et al. A prospective study on the dying process in terminally ill cancer patients. American Journal of Hospice Palliative Care, 1998, 15, 217-222.

4 Quill, T.E. \& I.R. Byock; ACP-Asim End-of-Life Care Consensus Panel. Responding intractable suffering: The role of terminal sedation and voluntary refusal of foods and fluids. Annals of Internal Medicine, 2000, 132, 408-414.

5 Sykes, N. \& A. Thorns. Sedative use in the last week of life and the implication for end-of-life decision making. Archives of Internal Medicine, 2003, 163, 341-344.

6 Cowen, J.D. \& D. Walsh. Terminal sedation in palliative medicine. Supportive Cancer Care, 2001, 9, 403-407.

7 Ellershaw, J. \& S. Wilkinson. Care of the Dying: A pathway of excellence. Oxford University Press, Oxford, 2003 .

8 Veerbeek, L. Care and quality of life in the dying phase. The contribution of the Liverpool Care Pathway for the dying patient. Proefschrift. Rotterdam, 2008.

9 Mertens, T. Het Zorgpad Stervensfase. Masterproef Verpleeg- en Vroedkunde. Universiteit Antwerpen, 2008.

10 Mertens, T., T. De Vlieger, M. Elseviers \& B. Van den Eynden. Het Zorgpad Stervensfase: implementatie op een palliatieve eenheid. Nederlands Tijdschrift voor Palliatieve Zorg, 2008, 93, 6-14.

11 Van Roy, K. Hoe gebeurt de terminale zorg voor de stervende patiënt in de huisartsenpraktijk en kan deze verbeterd worden door implementatie van het 'Liverpool Care Pathway for the Dying Patient' in de Vlaamse thuiszorg? Thesis. Huisartsgeneeskunde, ICHO, Antwerpen, 2009. 


\subsection{COMPLEMENTAIRE ZORGTOEPASSINGEN IN DE PALLIATIEVE ZORG}

\section{Adriaan Visser en Katrien Moens}

In de gezondheidszorg is er een groeiende belangstelling voor complementaire zorg (CZ) door en voor verpleegkundigen en verzorgenden. Het handboek Inleiding complementaire zorg, specifiek gericht op verpleegkundigen en verzorgenden, is daar een illustratie van. ${ }^{1}$ Deze belangstelling geldt vooral voor mensen met een levensbedreigende of chronische ziekte, waarbij in de zorg de nadruk ligt op het bevorderen van de kwaliteit van leven. Binnen de palliatieve zorg wordt CZ toegepast in hospices, ziekenhuizen, rusthuizen en verpleeg- en verzorgingshuizen, waar niet de genezing van de patiënten voorop staat, maar hun welbevinden. Zo worden bijvoorbeeld in sommige hospices etherische olie, massages en muziek gebruikt om de klachten te verminderen en meer ontspanning te geven. Gezien de toegenomen interesse van patiënten is het te verwachten dat hulpverleners vaker advies gevraagd zal worden over complementaire interventies en dat hulpverleners ook actief betrokken zijn bij de uitvoering ervan. Bovendien raken steeds meer zorgverleners vanuit hun eigen beroep geïnteresseerd in de aanvullende mogelijkheden van $\mathrm{CZ} .{ }^{2}$

\subsubsection{Omschrijuing van complementaire zorg}

$\mathrm{CZ}$ wordt internationaal gerekend tot de complementary and alternative medicine (CAM). Daarom is het van belang een duidelijk onderscheid te maken tussen alternatieve geneeswijzen en $\mathrm{CZ} .{ }^{3}$ Bij alternatieve geneeswijzen (bijvoorbeeld bepaalde voeding, homeopathie en acupunctuur) ligt de nadruk primair op genezing (cure). $\mathrm{Bij} \mathrm{CZ}$ is deze pretentie er niet en staat de zorg (care) voorop. Voorbeelden daarvan zijn massage, ontspanningsoefeningen, werken met aroma's, kleuren, muziek en visualisatietechnieken. Het onderscheid is van belang omdat de alternatieve geneeswijzen door de pretentie tot genezing op weerstanden in de medische wereld stuiten, meer dan voor CZ het geval is. ${ }^{3}$ In feite maken veel artsen geen bezwaar tegen de CZ, omdat die de medische behandeling ondersteunen en niet vervangen. ${ }^{4.5}$ In de antroposofische zorg is veel expertise in het gebruik van kruiden, massages (inwrijvingen) en etherische oliën in de zogenoemde uitwendige therapieën. Het concept van de antroposofische benadering neemt in de gezondheidszorg een aparte plaats in, met een eigen en uitgebreide mensvisie en traditie. ${ }^{2}$

\subsubsection{Gebruik van complementaire zorg}

Over de omvang van het gebruik van $\mathrm{CZ}$ in de palliatieve fase is weinig bekend. In Nederland komt de toepassing van muziek, massage, werken met geuren, en creatieve therapie voor in hospices en op de afdelingen palliatieve zorg in ziekenhuizen. Door De Graeff en Kroeze-Hoogendoorn wordt het gebruik in de palliatieve zorg globaal geschat op 50-60\%. ${ }^{6}$ Recente cijfers liggen iets lager, namelijk $39 \%$ en dalen 
naarmate het levenseinde nadert.7 Het gebruik van CZ door mensen met kanker is de afgelopen decennia in Nederland gestegen van $15 \%$ naar $30 \% .8$

Uit een onderzoek naar de implementatie van complementaire zorgvormen onder een grote groep personen die ooit congressen over complementaire zorg hebben bijgewoond, blijkt dat er de afgelopen jaren in Nederland 48 projecten op het terrein van complementaire zorg binnen zorginstellingen ontwikkeld zijn. ${ }^{9}$ Met name verpleegkundigen (60\%) zijn veel bij deze projecten betrokken. Het betreft vooral projecten over massage $(61 \%)$, therapeutic touch $(50 \%)$, werken met etherische oliën (44\%), ontspanningsvormen ( $26 \%$ ) en luisteren naar muziek (24\%). Een recente ontwikkeling vormt de toepassing van meditatie met ontspanningsoefeningen (mindfulness-based stress reduction, MBSR) voor chronisch zieken en mensen met kanker. ${ }^{10}$ In Vlaanderen werden in 2006 de eerste stappen gezet in het onderzoek naar de omvang van het gebruik van $\mathrm{CZ}$ in de palliatieve fase. Cijfers toonden aan dat $95 \%$ van de verpleegkundigen werkend op een palliatieve zorgeenheid CZ toepast. De meest uitgevoerde CZ-interventies binnen een palliatieve zorgeenheid zijn: het werken met aroma's, massage en het werken met muziek. De voornaamste zorgvragen waarvoor deze interventies worden aangewend, zijn angst, onrust, spanning, geurverdoezeling, stervensbegeleiding, slapeloosheid en pijn."

\subsubsection{Complementaire zorg in de verpleging en verzorging}

Het gaat bij CZ om afzonderlijke interventies, die passen binnen het competentiegebied van een bepaalde professie, zoals verpleegkunde, verloskunde, fysiotherapie of geneeskunde. In de verpleegkunde gaat het om complementaire interventies, die door Astrid Noorden worden gedefinieerd als:

Verpleegkundige interventies voortkomend uit de complementaire geneeswijzen in het verpleegkundig proces en in de verpleegkundige praktijk, die bij voorkeur worden toegepast om het zelfhelend vermogen van de patiënt te ondersteunen, te stimuleren of te activeren, waarbij de zorg de mentale, emotionele, lichamelijke, spirituele en sociale behoeften omvat, zodat de patiënt een staat van welbevinden kan (her)winnen. ${ }^{12}$

In de Nursing Intervention Classification (NIC) staan een aantal CZ-interventies expliciet erkend, zoals geleide fantasie, massage, meditatie en therapeutic touch. Dit onderstreept de visie dat deze CZ-interventies in zekere mate voldoen aan de eisen van een verpleegkundige interventie, waardoor zij kunnen worden gezien als een onderdeel van de reguliere verpleegkundige zorg. ${ }^{.2,13}$

$\mathrm{CZ}$ dient gegeven te worden door vakkundige en bekwame zorgverleners. Hoewel de genoemde interventies erg van elkaar verschillen, hebben ze met elkaar een holistische mensvisie gemeen en zijn ze erop gericht om het gezonde in de mens aan te spreken en te stimuleren. Verder is een aandachtsvolle bejegening door de 
zorgverlener een belangrijk uitgangspunt. Daarvoor is het nodig dat de zorgverlener zelf zo rustig mogelijk is voorafgaand aan en tijdens de toepassing van de interventie. ${ }^{14}$

\section{Meditatie geeft rust}

Meneer Terberg is opgenomen in verband met vage buikklachten. Hij krijgt morgen de uitslag van een coloscopie. Hij is erg gespannen. Hij vertelt dat hij normaal gesproken 's ochtends in stilte mediteert en dat hem dit vertrouwen geeft en rustig maakt. Deze rust mist hij nu. De verpleegkundige vraagt meneer of hij nu behoefte heeft om te mediteren. Meneer geeft aan dat het hem op dit moment niet lukt om zich op de meditatie te concentreren. De verpleegkundige vraagt hem of zij een geleide fantasieoefening met hem zal doen. Meneer stemt toe. In de oefening maakt de verpleegkundige gebruik van beelden waarvan stilte uitgaat, zoals een berglandschap. Meneer Terberg laat zich leiden door de rustige stem van de verpleegkundige. Zijn ademhaling wordt rustiger, zijn houding meer ontspannen. Na de oefening vertelt hij dat hij zich meer in balans voelt.

In dit voorbeeld zijn de volgende principes herkenbaar.

w De verpleegkundige handelt vanuit haar rol als verpleegkundige: het reduceren van stress hoort bij haar competenties.

* Door de rustige stem van de verpleegkundige en de keuze van de visualisatie kan meneer beter ontspannen en voelt hij zich meer in balans. Dit draagt bij aan zijn welbevinden.

= Het holistisch mensbeeld komt in dit voorbeeld niet zo duidelijk naar voren. De verpleegkundige gaat in op de angst van meneer Terberg. Angst kan het totale functioneren verlammen. De angst van meneer Terberg heeft te maken met zijn lichamelijke klachten. Indirect is er wel verband met het holistisch mensbeeld.

= In dit voorbeeld wordt er geen gebruikgemaakt van materialen of natuurlijke stoffen. In dit voorbeeld gaat het om het stimuleren van de balans. Meneer Terberg benoemt dit ook zo.

w Meneer vertelt dat meditatie hem helpt om vertrouwen te hebben en ontspannen te zijn.

II De verpleegkundige neemt de angst van meneer Terberg serieus. Zij zoekt samen met hem een manier om hiermee om te gaan die past bij de gewoontes van meneer. De rustige stem, en waarschijnlijk ook de houding van de verpleegkundige zijn belangrijk voor visualisatieoefeningen. Als de verpleegkundige niet rustig is kan zij deze interventie niet toepassen.

Ontleend aan Inleiding complementaire zorg, p. 33.' 


\subsubsection{Richtlijnen}

In het handboek Inleiding complementaire zorg zijn inmiddels diverse richtlijnen beschikbaar voor de toepassing van CZ. ${ }^{1}$ In het boek wordt voor zes vormen van $\mathrm{CZ}$ die soms door verpleegkundigen worden toegepast (massage, werken met kruiden, toepassen van etherische oliën, werken met muziek, ontspanningsoefeningen en therapeutic touch), ingegaan op:

= de geschiedenis en achtergronden;

II werkingsprincipes;

I de keuze van de interventie;

III verpleegkundige diagnose voor de toepassing van de CZ-vorm;

w contra-indicaties;

III effecten;

- specifieke aandachtspunten bij de toepassing;

= rapportage;

= toepassing door zorgvrager of mantelzorgers.

Verder geeft het handboek Richtlijnen palliatieve zorg, een uitgave van het Integraal Kankercentrum Midden-Nederland (IKMN), uitvoerige informatie over vier CZinterventies die zowel door professionele als niet-professionele hulpverleners aangeleerd en uitgevoerd kunnen worden, en na instructie vaak ook overdraagbaar zijn aan de patiënt zelf en/of de mantelzorgers: klassieke massage, toepassen van etherische oliën, ontspanningsoefeningen, en luisteren naar muziek, die soms ook in combinatie met elkaar kunnen toegepast worden.15 In dit kader willen we ook wijzen op de brochure van de Verpleegkundigen \& Verzorgenden Nederland (V\&VN).$^{16}$ De daarin vermelde checklists voor de discussie over en de implementatie van complementaire zorg zijn erg handig bij de besluitvorming over de keuzen voor bepaalde complementaire zorgvormen. Zij vallen volgens de V\&VN vaak buiten de reguliere interventies en vereisen daardoor zorgvuldige discussie over de plaats van complementaire zorg in zorginstellingen.

\subsubsection{Opleiding}

In Nederland is er een aparte opleiding in de $\mathrm{CZ}$ voor verpleegkundigen en verzorgenden. ${ }^{1, n, 17,18}$ Eveneens is er een verpleegkundige richtlijn over complementaire zorg, uitgegeven door de eigen beroepsvereniging. In Vlaanderen organiseren heel wat vormingsinstellingen en instellingen voor hoger onderwijs voortgezette opleidingen in verband met CZ-interventies.

\subsubsection{Inpassing in de organisatie}

Het is van belang dat over de toepassing van CZ-interventies overlegd wordt met het behandelend team, omdat CZ altijd aanvullend is op en ondersteunend is aan 
de aanwezige standaardzorg. Binnen organisaties en zorginstellingen moet consensus bestaan over het al dan niet toepassen van verschillende vormen van $C Z$ en moet duidelijk zijn wie verantwoordelijk is voor de uitvoering van de complementaire interventies. Hulpverleners behoren op de hoogte te zijn van elkaars interventie en dienen goed samen te werken. Ten aanzien van de uitvoering is er aandacht nodig voor afspraken over verslaglegging en continuïteit. De verslaglegging moet de betrokken hulpverleners een goed beeld geven van de indicatie, de interventie, hoe de interventie uitgevoerd werd en wat het effect ervan is op de ervaren klacht en het algemeen welbevinden.19 ${ }^{19}$ inpassing van CZ-vormen in de palliatieve zorg vereist dus expliciete aandacht voor de ruimte die de organisatie biedt aan CZ, zoals ook de V\&VN benadrukt voor de gezondheidszorg in het algemeen. ${ }^{16}$

\subsubsection{Indicatie voor de vorm van complementaire zorg}

Er zijn veel overeenkomsten in de indicaties voor de toepassing van de beschreven interventies. CZ wordt in de palliatieve zorg vooral toegepast om ontspanning te bieden en welbevinden te bevorderen en kan dus geïndiceerd zijn bij pijn, misselijkheid, slaapproblemen, spanning en onrust, angst en sombere stemming. In veel gevallen ontbreekt onderbouwing om duidelijk aan te kunnen geven welke interventie de voorkeur heeft bij een bepaalde indicatie. Daarom zal vooralsnog de keuze voor een interventie bepaald worden door de voorkeur en/of ervaring van de patiënt, de beschikbare kennis en ervaring van de betrokken hulpverleners en de mogelijkheden in de zorgsituatie. Een CZ-interventie kan worden ingezet op verzoek van de patiënt of de mantelzorg, maar ook op initiatief van de betrokken hulpverleners zelf, als zij vermoeden dat dit het comfort of het welzijn van de patiënt kan verbeteren. Op dit moment is er vaak nog onvoldoende bewijs beschikbaar over de werkzaamheid van verschillende complementaire interventies. Een groot deel van de gegevens en adviezen berust op een beperkt aantal onderzoeken en vooral op praktische ervaring. Er is evenwel een groeiend aantal overzichtsartikelen waaruit opgemaakt kan worden dat vormen van massage, het toepassen van etherische oliën en ontspanningsoefeningen effectief zijn voor het verminderen van pijn, spanning en slapeloosheid. ${ }^{1,15}$ In het handboek Inleiding complementaire zorg wordt uitgebreid stilgestaan bij de ontwikkeling en belemmeringen van onderzoek naar $\mathrm{CZ}$ in de verpleegkundige setting.'

\section{5 .8 Conclusie}

De CZ is niet weg te denken uit de palliatieve zorg. Het levert een belangrijke bijdrage aan het in stand houden van en het verbeteren van het welbevinden van patiënten. $\mathrm{CZ}$ kan ook voor mantelzorgers, verpleegkundigen en verzorgenden veel betekenen voor hun zelfzorg. 


\section{LITERATUUR}

1 Busch, M., A. Huisman, S. Hupkens \& A. Visser (red.). Inleiding complementaire zorg. Elsevier Gezondheidszorg, Maarssen, 2006.

2 Hupkens, S. Complementaire zorg in het verpleegkundig beroep. In: Busch, M., A. Huisman, S. Hupkens \& A. Visser (red.). Inleiding complementaire zorg. Elsevier Gezondheidszorg, Maarssen, 2006, 49-76.

3 Busch, $\mathrm{M}$. Complementaire zorg in relatie tot complementaire en alternatieve geneeswijzen, In: Busch M., A. Huisman, S. Hupkens \& A. Visser (red.). Inleiding complementaire zorg. Elsevier Gezondheidszorg, Maarssen, 2006, 93-109.

4 Gelder, R. de, A. Visser \& L. van Zuylen. Effects of facial massage on quality of life of patients with cancer. Helen Dowling Instituut, Utrecht, 2004.

5 Berg, M. van den, A. Visser, A. Schoolmeesters, et al. Evaluation of haptotherapy for patients with cancer treated with chemotherapy at a day clinic. Patient Education and Counseling, 2006, 60, 336-343.

6 Graeff, A. de \& G.J. Kroeze-Hoogendoorn. Complementaire zorg in de palliatieve zorg. Bulletin COPZ-U, Utrecht, 1999.

7 Visser, A., E. de Vogel-Voogt \& A. van der Heide. Complementaire zorg en alternatieve geneeswijzen bij kankerpatiënten in de laatste levensfase: een verkennend onderzoek. Nederlands Tijdschrift voor Palliatieve Zorg, 2008, 1, 21-26.

8 Zouwe, N. van der \& F.S.M. van Dam. De betekenis van alternatieve behandelwijzen voor patiënten in de oncologie. In: Haes, J.C.J.M. de, L. Gualtherie van Weezel \& R. Sanderman (red.). Psychologische zorg in de oncologie. NKB/Van Gorcum, Amsterdam/Assen, 2001.

9 Boogaart, J., A. Visser, D. de Ridder, et al. Implementatie van complementaire zorg: onderzoek naar de factoren die het implementatieproces van complementaire zorg in de standaardzorg beinvloeden. HDI, Utrecht, 2004 .

10 Kievit-Stijnen, A., A. Visser, B. Garssen \& W. Hudig. Mindfulness-based stress reduction training for oncology patients: patients' appraisal and changes in well being. Patient Education and Counseling, 2008, 72, 436-442.

11 Moens, K. Verpleegkundige complementaire zorgverlening binnen alle Vlaamse palliatieve zorgeenheden. Masterproef Verplegingswetenschappen. Vrije Universiteit Brussel, 2007.

12 Noorden, A. De toepassing van natururlijke behandelmethoden door verpleegkundigen. Tijdschrift voor Integrale Geneeskunde, 1996, 12, 198-205.

13 Busch, M. Complementaire zorg: toch regulier? Nursing, 2002 juni, 38-39.

14 Busch, M. Complementaire zorg en de zorgverlener. In: Busch M., A. Huisman, S. Hupkens \& A. Visser (red.). Inleiding complementaire zorg. Elsevier Gezondheidszorg, Maarssen, 2006, 207-219.

15 Richtlijnen palliatieve zorg. IKMN, Utrecht, 2010.

16 Hoe bespreek je complementaire zorg in je instelling: checklist voor discussie, checklist voor implementatie. V\&VN, Utrecht, 2006.

17 Huisman, A. Complementaire zorg in de praktijk. In: Busch, M., A. Huisman, S. Hupkens \& A. Visser (red.). Inleiding complementaire zorg. Elsevier Gezondheidszorg, Maarssen, 2006, 77-92.

18 www.venvn.nl.

19 Wysmans, M. Implementatie van complementaire zorg. In: Busch, M., A. Huisman, S. Hupkens \& A. Visser (red.). Inleiding complementaire zorg. Elsevier Gezondheidszorg, Maarssen, 2006, 479-510. 


\section{6 RICHTLIJNEN VOOR PALLIATIEVE ZORG}

\section{Madeleen Uitdehaag en Alexander de Graeff}

Richtlijnen zijn op wetenschappelijke onderzoeksresultaten of op consensus gebaseerde inzichten en aanbevelingen waaraan zorgverleners moeten voldoen om kwalitatief goede zorg te verlenen. Ze beschrijven de tot op heden effectief gebleken methode(n) van diagnostiek en behandeling en bieden zorgverleners ondersteuning bij de klinische besluitvorming. Richtlijnen zijn geen wettelijke voorschriften, maar wanneer van de richtlijn wordt afgeweken, dient dit wel te worden beargumenteerd en gedocumenteerd. ${ }^{1}$ In Nederland worden vanaf 1992 richtlijnen ontwikkeld voor de palliatieve zorg. Deze hebben in de afgelopen jaren hun weg gevonden naar huisartsen, specialisten, arts-assistenten, apothekers, verpleegkundigen en paramedici werkzaam binnen de palliatieve zorg, eerst in de regio Midden-Nederland en later in heel het land.

\subsubsection{De geschiedenis van de richtlijnen palliatieve zorg}

De ontwikkeling van richtlijnen op het gebied van de palliatieve zorg is gestart in 1992 met de oprichting van de multidisciplinaire werkgroep Palliatieve Zorg van het Integraal Kankercentrum Midden-Nederland (IKMN; per 1 januari 2011 zijn de zeven integrale kankercentra in Nederland gefuseerd tot de Integrale Kankercentra Nederland; IKNL). Vier jaar later verscheen het Oncologieboek met daarin onder andere elf door de werkgroep Palliatieve Zorg ontwikkelde richtlijnen palliatieve zorg. ${ }^{2} \mathrm{Na}$ het verschijnen van het Oncologieboek werd een aparte redactie (bestaande uit drie artsen en twee verpleegkundigen) samengesteld die verder ging met de ontwikkeling van richtlijnen voor de palliatieve zorg. Dit resulteerde in 2002 in een herziene uitgave van het Oncologieboek, bestaande uit twee delen: tumorspecifieke richtlijnen (deel 1) en 21 richtlijnen palliatieve zorg (deel 2). ${ }^{3}$

$\mathrm{Na}$ het verschijnen van het Oncologieboek in 2002 werd een nieuwe redactie samengesteld voor het schrijven van een richtlijnenboek uitsluitend voor de palliatieve zorg. De redactie bestond uit leden van de werkgroep Palliatieve Zorg van het IKMN en leden van de werkgroep Kwaliteitsbevordering Palliatieve Zorg (Quapal) van het Integraal Kankercentrum Oost (IKO). In deze periode werd het project van richtlijnontwikkeling officieel overgedragen aan de toenmalige landelijke koepelorganisatie, de Vereniging van Integrale Kankercentra (VIKC). Dit bood deskundigen van alle integrale kankercentra de mogelijkheid om de richtlijnen mede te beoordelen tijdens de commentaarfase. In 2006 verscheen het richtlijnenboek van de VIKC: Palliatieve zorg: richtlijnen voor de praktijk. Hierin werden de bestaande richtlijnen herzien en elf nieuwe richtlijnen toegevoegd, waaronder drie richtlijnen op het gebied van de psychosociale zorg (mantelzorg, existentiële crisis en rouw) en twee niet-oncologische ziektebeelden (ALS en hartfalen). ${ }^{4}$ Een andere belangrijke 
verandering was de toevoeging van het stappenplan en van de niveaus van bewijsvoering voor de gegeven adviezen, die bedoeld waren als een eerste aanzet om de richtlijnen evidence based te maken.

Tot slot opende de VIKC kort na de uitgave van hun richtlijnenboek ook een website (www.pallialine.nl) waarop alle Nederlandse richtlijnen palliatieve zorg zijn in te zien en te downloaden. De site was een afgeleide van www.oncoline.nl waarop de tumorspecifieke richtlijnen zijn te raadplegen en die ook in beheer was van de VIKC. Het voordeel van de website is dat deze altijd up-to-date is: een nieuw ontwikkelde of gereviseerde richtlijn palliatieve zorg wordt direct op de site geplaatst. De website heeft het ook mogelijk gemaakt om nieuwe of gereviseerde conceptrichtlijnen door zorgverleners uit het hele land te laten beoordelen en van commentaar te voorzien, waardoor de richtlijnen steeds meer een landelijk gedragen basis kregen.

In december 2010 is de meest recente versie van het richtlijnenboek verschenen (zie paragraaf 4.6 .5 ). ${ }^{5}$

\subsubsection{Doelen en doelgroepen van de richtlijnen}

Het primaire doel van de richtlijnen is de kwaliteit van de palliatieve zorg te verbeteren op het niveau van de individuele patiëntenzorg door adviezen over diagnostiek en behandeling te geven. Daarnaast kunnen ze ook gebruikt worden als hulpmiddel bij de consultatie op het gebied van de palliatieve zorg, om de kennis op het gebied van de palliatieve zorg te vergroten en voor onderwijs en bijscholing.

De richtlijnen palliatieve zorg zijn vooral bedoeld voor artsen, verpleegkundigen en apothekers in de eerste en in de tweede lijn, die zorg verlenen aan patiënten in de palliatieve fase van de ziekte. Ze bestrijken de gehele periode vanaf het moment dat genezing niet (meer) mogelijk is tot aan het overlijden en beperken zich niet tot alleen de terminale fase. De toepasbaarheid en zinvolheid van de diagnostiek en de behandelingen die in de richtlijnen aan de orde komen, zijn sterk afhankelijk van de fase van het ziekteproces en de levensverwachting. De zorgverlener die van deze richtlijnen gebruikmaakt, moet dus een keuze maken welke van de in de richtlijnen genoemde mogelijkheden voor diagnostiek en behandeling van toepassing zijn op de situatie van de patiënt om wie het gaat en op zijn of haar werkplek en discipline.

\subsubsection{Het niveau van bewijsvoering}

De richtlijnen palliatieve zorg pretenderen niet 'volledig' evidence based te zijn. De procedure die hiervoor noodzakelijk is, was niet uitvoerbaar binnen de beperkingen van het tijdsbestek en de financiële mogelijkheden die beschikbaar waren voor de redactie van de richtlijnen palliatieve zorg. Voor alle in het stappenplan gegeven behandelingsadviezen wordt wel aangegeven welk niveau van bewijsvoering hieraan ten grondslag ligt met vermelding van de relevante literatuur.45 Het hoogste niveau, niveau 1, wordt verkregen als er ten minste twee gerandomiseerde studies zijn van goede kwaliteit, die een eenduidige conclusie opleveren over de effectiviteit van een 
behandeling. Niveau 2 wordt bereikt op basis van ten minste twee vergelijkende studies van matige kwaliteit of onvoldoende omvang. Niveau 3 is gebaseerd op één vergelijkend onderzoek of op niet-vergelijkend onderzoek. Bij niveau 4 is er sprake van adviezen op basis van case-reports of expert opinion. Het mag duidelijk zijn dat niveau 1 uiterst zelden voorkomt in de palliatieve zorg. Vaker zal slechts niveau 2 of niveau 3 van toepassing zijn. Bij niveau 4 kunnen sommige case-reports betrekking hebben op vaak voorkomende situaties en als zodanig toch een belangrijke bijdrage leveren om in moeilijke omstandigheden te beslissen en te handelen.

\subsubsection{Het proces van richtlijnontwikkeling}

Waar de richtlijnen eerst door de leden van de werkgroep Palliatieve Zorg van het IKMN werden samengesteld en gepubliceerd, zijn de meest recente richtlijnen geschreven door auteurs op uitnodiging en becommentarieerd door diverse zorgverleners binnen de palliatieve zorg. In grote lijnen is het proces in te delen in zes stappen, die zijn afgeleid van de ontwikkeling van tumorspecifieke richtlijnen.

- Stap 1: Ondenwerpkeuze en afbakening. De redactie bepaalt op grond van eigen inzichten en signalen of suggesties vanuit het werkveld het onderwerp van de nieuw te ontwikkelen richtlijn.

= Stap 2: Voorbereiding. De redactie bepaalt de eerste auteur van de richtlijn, waarna zij gezamenlijk de (maximaal drie) overige auteurs bepalen. De groep van auteurs moet minimaal één verpleegkundige en minimaal één arts bevatten.

- Stap 3: Ontwikkelen van een conceptrichtlijn. De auteurs stellen de tekst voor de conceptrichtlijn op na een literatuurstudie op het onderwerp. Zij kunnen daarbij ondersteuning vragen van een projectmedewerker van de VIKC. De redactie geeft als eerste commentaar op de richtlijn en redigeert deze voor de landelijke commentaarronde.

- Stap 4: Landelijke commentaarronde. De conceptrichtlijn wordt opgestuurd naar alle coördinatoren palliatieve zorg van de regionale IKC's en geplaatst op de website www.pallialine.nl, waarna de mensen die op de website hebben aangegeven geïnformeerd te willen worden over conceptrichtlijnen (notificaties) en nader te bepalen beroepsverenigingen en individuen worden uitgenodigd om hun commentaar te geven op de richtlijnen. Alle commentaren worden gebundeld en na sluitingsdatum (drie maanden later) naar de eerste auteur verzonden. De auteurs van de richtlijn verwerken de commentaren in de eindversie, waarna de redactie uiteindelijk de definitieve richtlijn vaststelt.

I Stap 5: Verspreiding en implementatie. De definitieve richtlijn wordt ingevoerd in www.pallialine.nl en er gaat een nieuwsbericht uit naar alle coördinatoren palliatieve zorg van de IKC's (dat zij verspreiden onder hun netwerken), 
vaktijdschriften zoals Pallium en het Nederlands Tijdschrift voor de Palliatieve Zorg (NTPZ) en overige belangstellenden. Om de implementatie te bevorderen zijn er van alle symptoomrichtlijnen samenvattingen gemaakt, die gebonden zijn in het zakboekje. ${ }^{6}$ Dit boekje is handig bij de directe zorgverlening aan bed met de patiënt.

= Stap 6: Evaluatie, actualisatie en revisie. Elke richtlijn wordt na maximaal vijf jaar herzien, of eerder indien de actualiteit dit vraagt. Tijdens de revisie van een richtlijn worden alle bovenstaande stappen opnieuw doorlopen.

\subsubsection{Het format van de richtlijnen palliatieve zorg}

Bij het opstellen van de richtlijnen palliatieve zorg is er gestreefd naar een multidimensionale benadering en een uniforme opzet van alle richtlijnen.

Achtereenvolgens komen in de richtlijnen de volgende onderwerpen aan bod:

= inleiding: begripsbepaling en achtergrondinformatie;

III voorkomen: frequentie van voorkomen van het probleem;

II ontstaanswijze;

= oorzaken;

- diagnostiek: anamnese, lichamelijk onderzoek en aanvullend onderzoek;

* beleid met achtereenvolgens aandacht voor:

- integrale benadering (voorlichting, communicatie, ondersteunende zorg, continuïteit van zorg),

- behandeling van de onderliggende oorzaak,

- niet-medicamenteuze symptomatische behandeling,

- medicamenteuze symptomatische behandeling;

= stappenplan ten aanzien van diagnostiek en behandeling;

- niveaus van bewijsvoering;

w referenties.

Omdat niet alle onderdelen voor iedere richtlijn relevant zijn, worden soms onderdelen achterwege gelaten.

\subsubsection{Overzicht van de richtlijnen palliatieve zorg}

Eind 2010 is een nieuwe uitgave van het richtlijnenboek Palliatieve zorg: richtlijnen voor de praktijk verschenen. Dit boek bevat negen nieuwe en 31 gereviseerde richtlijnen; zie tabel 4.1 voor de onderwerpen van de richtlijnen in deze nieuwe uitgave. 5 De redactie zal zich gaan beraden over de toekomst van de richtlijnen palliatieve zorg in Nederland. Vanuit de kenniscentra bestaat de wens de richtlijnen 'volledig' evidence based te ontwikkelen. Bovendien zouden de richtlijnen door de beroepsverenigingen binnen de palliatieve zorg geautoriseerd kunnen worden. 
Tabel 4.1 Onderwerpen van de richtlijnen uit het. VIKC-richtlijnenboek 2010

\begin{tabular}{lll}
\hline Basisonderwerp van de richtlijn & Aantal & Richtijn \\
\hline Symptomen en syndromen & 29 & $\begin{array}{l}\text { angst, anorexie en gewichtsverlies, } \\
\text { ascites, dehydratie en vochttoediening, } \\
\text { delier, depressie, diarree, dwarslaesie, } \\
\text { dyspnoe, hersenmetastasen, hik, hoesten, } \\
\text { hypercalciëmie, ileus, jeuk, koorts, } \\
\text { lymfoedeem, misselijkheid en braken, } \\
\text { mondklachten, obstipatie, oncologische ulcera, } \\
\text { pijn, slapproblemen, zorg in de stervensfase, } \\
\text { diepe veneuze trombose en longembolie, } \\
\text { urogenitale problemen, vena cava superior- } \\
\text { syndroom, vermoeidheid bij kanker, zweten } \\
\text { ALs, copD, dementie, hartfalen }\end{array}$ \\
Niet-oncologische ziektebeelden & 4 & $\begin{array}{l}\text { euthanasie en hulp bij zelfdoding, palliatieve } \\
\text { sedatie }\end{array}$ \\
Overige & 2 & $\begin{array}{l}\text { complementaire zorg, palliatieve zorg voor } \\
\text { mensen met een verstandelijke beperking, } \\
\text { mantelzorg, spirituele zorg, rouw }\end{array}$
\end{tabular}

\subsubsection{Conclusie}

Binnen Nederland wordt al sinds 1992 gewerkt aan de ontwikkeling van multidisciplinaire richtlijnen voor de palliatieve zorg. In het proces van de afgelopen bijna twintig jaar is het ontwikkelingsproces van regionaal naar landelijk gegaan, is een eerste aanzet gedaan naar evidence-based richtlijnontwikkeling en is het draagvlak vergroot door de landelijke commentaarrondes. In 2010 is een nieuw richtlijnenboek palliatieve zorg verschenen, waarin de veertig tot nu toe ontwikkelde richtlijnen zijn opgenomen.

\section{LITERATUUR}

1 Burgers, J.S., R. Grol, N.S. Klazinga, et al.; AGREE Collaboration. Towards evidence-based clinical practice: an international survey of 18 clinical guideline programs. International Journal for Quality in Health Care, 2003, 15, 31-45.

2 Berg, W.N. van de, M.R. Eliel \& L.A. Ravasz. Oncologieboek IKMN: richtlijnen voor diagnostiek en behandeling van kanker voor medisch specialisten en huisartsen in de IKMN-regio. Integraal Kankercentrum Midden-Nederland, Utrecht, $199^{2}$.

3 Graeff, A. de, E.H. Verhagen, M.R. Eliel, et al. Oncologieboek deel II. Richtlijnen palliatieve zorg. Integraal Kankercentrum Midden-Nederland, Utrecht, 2002.

4 Graeff, A. de, G.M. Hesselman, R.J.A. Krol, et al. Palliatieve zorg, richtlijnen voor de praktijk. VIKC, Utrecht, 2006.

5 Graeff, A. de, J.M.P. van Bommel, R.H.P.D. van Deijck, et al. Palliatieve zorg: richtlijnen voor de praktijk. VIKC, Utrecht, 2010.

6 Gootjes, I., A. Jobse \& A. de Graeff. Zakboekje palliatieve zorg. VIKC, Utrecht, 2010. 


\section{Palliatieve zorg voor specifieke groepen}

5.1 Palliatieve zorg voor mensen met dementie $\quad 156$

5.2 Palliatieve zorg voor kinderen 162

5.3 Palliatieve zorg voor mensen met een niet-westerse achtergrond. $\quad 172$

5.4 Palliatieve zorg voor mensen met een verstandelijke beperking $\quad 178$

5.5 Palliatieve zorg in de psychiatrie 185 


\section{Aart Eliens en Jenny van der Steen}

Onder de 65-plussers in België heeft ongeveer 9,3\% dementie. Dit loopt op tot 34,8\% bij 90 -plussers. In Nederland heeft ongeveer een kwart van de vrouwelijke 90 -plussers dementie en bijna één op de zes mannen. Bovendien heeft in Nederland één op de negen personen die overlijdt dementie en de verwachting is dat komende decennia nog meer mensen met dementie zullen overlijden. ${ }^{2}$ De meeste mensen die lijden aan dementie verblijven de laatste fase van hun leven in een instelling (in Nederland meestal een verpleeg- of verzorgingshuis, in Vlaanderen een rust- of bejaardenoord). Zorg voor mensen met dementie is in principe palliatief, omdat de zorg gericht is op verzachting van lijden en het bevorderen van de kwaliteit van leven. ${ }^{3}$

Deze paragraaf gaat in op een aantal aspecten van de zorg tijdens de laatste fase van de dementie.

\subsubsection{Wat maakt palliatieve zorg bij mensen met dementie specifiek?}

Palliatieve zorg bij dementie is complex. ${ }^{4}$ Dit wordt mede veroorzaakt door de beperkte mogelijkheden om verbaal te communiceren. Naarmate de dementie voortschrijdt, neemt het vermogen om verbaal te communiceren af. Dit bemoeilijkt de communicatie tussen de persoon met dementie en zorgverleners aanzienlijk. Hierdoor is het ook moeilijk om gezondheidsklachten en zorgbehoeften van mensen met dementie helder te krijgen.

Mensen met dementie lijden over het algemeen waarschijnlijk langduriger aan belastende symptomen en pijn in de laatste levensfase dan bijvoorbeeld mensen met kanker. De achteruitgang is vaak geleidelijk, maar soms ook enigszins grillig. Dit langdurige verloop en het feit dat mensen met dementie vaak voordat zij in de terminale fase komen, opgenomen worden in een instelling, biedt ook voordelen. Het betekent dat zorgverleners een goede relatie kunnen opbouwen met de patiënt en de familie. Ook kunnen zij over de informatie beschikken om goede besluiten te nemen over de benodigde zorg in de allerlaatste fase van de ziekte. 5

Toch kunnen diverse problemen in de palliatieve zorg bij mensen met dementie spelen. Zo worden soms maatregelen toegepast waarvan de noodzaak betwijfeld kan worden, bijvoorbeeld het geven van sondevoeding, intraveneuze voeding of antibiotica.5 Ook is bekend dat de besluitvorming over verpleegkundige en medische interventies soms niet goed gedocumenteerd wordt. Zorgprofessionals geven zelf ook aan dat zij op een aantal terreinen hun zorg kunnen verbeteren, bijvoorbeeld bij het omgaan met longontsteking, pijn en bij besluitvorming. Op deze aspecten wordt verderop in deze paragraaf nader ingegaan. 


\subsubsection{Prognose}

Bij mensen met dementie wordt soms zeer laat opgemerkt dat de terminale fase zich aankondigt. De (beperkte) levensverwachting is dan moeilijk in te schatten. De levensverwachting kan bijvoorbeeld samenhangen met het al dan niet krijgen van een pneumonie en die kans hangt ook weer met veel verschillende factoren samen, zoals aspiratie. Er zijn prognostische scores die op basis van onder andere ADLfunctioneren, verminderd bewustzijn, kortademigheid en verminderde inname van voeding, de kans op overlijden binnen bijvoorbeeld zes maanden aangeven. Er is ook een score speciaal voor kans op overlijden als een persoon met dementie ook een pneumonie ontwikkelt. ${ }^{6}$ De beste inschatting wordt over het algemeen verkregen uit een combinatie van de 'klinische blik' en zo'n prognostische score.

Op grond van hun ervaring en kennis van de patiënt kunnen verpleegkundigen samen met de arts een gesprek met de familie voeren over de prognose.

\subsubsection{Anticiperend beleid}

Frequent voorkomende problemen zijn longproblemen, moeite met de opname van voeding en vocht- en hartproblemen. ${ }^{5}$ Het is raadzaam tijdig met de patiënt (als dat nog kan) en de familie te bespreken wat de wensen zijn over het te volgen beleid indien deze problemen optreden. Dit beleid wordt niet altijd of niet tijdig besproken met de cliënt en de familie.7 Daarbij kan ook meespelen dat in instellingen weinig voorlichtingsmateriaal over veelvoorkomende zorgproblemen in de laatste fase van mensen met dementie aanwezig is. De gesprekken met de familie over zorg en behandeling vinden vaak plaats wanneer het sterven zeer nabij is. De heftige emoties die op dat moment bij de familie aanwezig zijn, maken de gesprekken met de familie soms ingewikkeld, zeker in die gevallen waarin verschillen van inzicht bestaan tussen familie en zorgverleners.

\subsubsection{Inzetten behandeling en zorg en wilsonbekwaamheid}

Bij het inzetten van behandeling en zorg bij mensen met dementie gelden dezelfde morele en juridische regels als bij andere patiënten. ${ }^{8}$ De besluitvorming verloopt als weergegeven in figuur 5.1. Patiënten kunnen deels bekwaam zijn om een beslissing te nemen en deels - dat wil zeggen voor een bepaald soort beslissing - onbekwaam zijn. Bijvoorbeeld: een vrouw met dementie kan soms nog wel beslissen of zij een jurk of een broek wil aantrekken. Maar het kan zijn dat zij geen oordeel kan vellen over de noodzaak een bepaalde behandeling te starten. Een ander uitgangspunt is dat zorgverleners niet voor een ander kunnen beoordelen of een besluit verstandig is. Verder moeten zorgverleners ervan uitgaan dat iemand zelf beslissingen kan nemen, totdat er goede argumenten zijn om dit niet aan te nemen. En ten slotte is een uitgangspunt dat alle patiënten zo veel als mogelijk moeten worden betrokken bij besluitvorming over behandeling of zorg. 


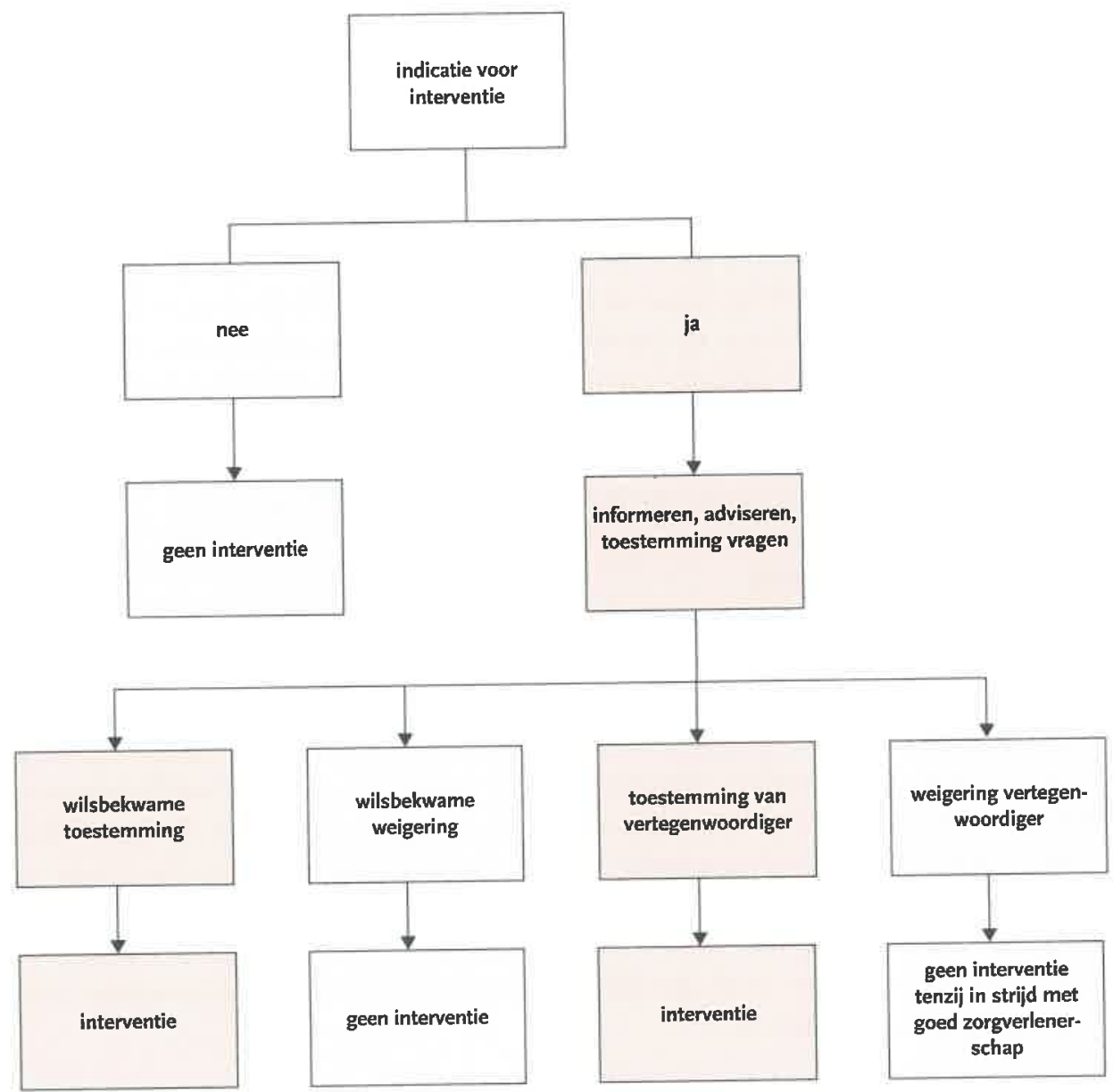

Figuur 5.1 Besluitvorming bij het inzetten van behandeling en zorg bij mensen met dementie

Bij de beoordeling of iemand zelf beslissingen kan nemen, kijk je of iemand een keuze kan maken en die kenbaar kan maken, de voor de te maken keuzen relevante informatie kan begrijpen en het vermogen heeft om de informatie te wegen of te waarderen. Indien er sprake is van wilsonbekwaamheid en er belangrijke besluiten nodig zijn over medische of verpleegkundige interventies, overleggen de verantwoordelijke zorgverleners met de vertegenwoordiger van de patiënt (een door de patiënt schriftelijk aangewezen gemachtigde, meestal een partner, kind, broer of zus).

\subsubsection{Contact met en behoeften van familie}

De laatste fase van een patiënt met dementie is voor de familie veelal belastend en zwaar. Zij maken het lijden mee van een dierbare, terwijl het vaak onmogelijk is 
nog verbaal contact te maken. De familie zal de wensen en behoeften van de patiënt kenbaar moeten maken aan allen die betrokken zijn bij de besluitvorming over de te verlenen zorg en behandeling.

Mantelzorgers hebben vaak langdurig gezorgd voor hun zieke partner of ouder. Deze zorgtaken zijn niet geheel voorbij indien hun dierbare wordt opgenomen in een instelling. De naaste familie heeft mede daarom vaak behoefte aan informatie over het te verwachten verloop van de ziekte en de problemen die kunnen spelen in de allerlaatste fase. Deze informatie is opgenomen in een schriftelijke handreiking voor familieleden van verpleeghuisbewoners met dementie, waarin ook palliatieve zorg wordt uitgelegd. 9 Daarnaast kunnen familieleden behoefte hebben aan informatie over hoe zij hun dierbare het best kunnen helpen, bijvoorbeeld bij eten en drinken of het verplaatsen in bed. Ook is het van belang dat zorgverleners met mantelzorgers spreken over wat het voor hen betekent dat zij de zorg thuis niet meer kunnen geven. Dit kan soms voorkomen dat zij schuldgevoelens ontwikkelen over de opname van hun dierbare.

De naaste familie heeft vaak veel kennis over de levensgeschiedenis, de voorkeuren en wensen van de persoon met dementie en het is belangrijk dat zorgverleners daarnaar vragen en waardering tonen voor de wijze waarop de familie bijdraagt aan de zorgverlening. ${ }^{10}$

\subsubsection{Pijn}

Pijn is een probleem dat veel voorkomt bij mensen in de laatste fase van dementie. De percentages genoemd in onderzoekspublicaties schommelen tussen de 12 en $83 \% .^{*}$ Wanneer pijn niet wordt opgemerkt en behandeld, heeft dit veel nadelige gevolgen. Niet-opgemerkte pijn kan leiden tot depressie, angst, sociale isolatie, slaapproblemen en beperkte mobiliteit. Uit onderzoek blijkt dat pijn vooral tijdens de ochtend veel voorkomt en dat de behandeling vaak faalt. ${ }^{22}$

De observatie van pijn is bij mensen met dementie, die hun klachten vaak niet kunnen verwoorden en verduidelijken, moeilijk. Zwakhalen onderzocht de kwaliteit van bestaande pijnobservatieschalen. ${ }^{12} \mathrm{Zij}$ concludeerde dat de PACSLAC-D en de PAINAD qua kwaliteit en bruikbaarheid goed scoorden. De PAINAD omvat slechts vijf items, terwijl de PACSLAC-D drie componenten (met 24 pijnuitingen) beslaat. Deze componenten hebben betrekking op gelaat, verzet/afweer en sociaalemotioneel/stemming. ${ }^{12}$ De PACSLAC-D en de PAINAD zijn voor verpleegkundigen en verzorgenden bruikbare observatie-instrumenten om uitingen die wijzen op pijn te signaleren en te registreren.

\subsubsection{Vocht- en voedinginname}

Mensen in de laatste fase van dementie gaan vaak steeds minder eten en drinken. Afgezien van behandelbare oorzaken zoals een niet-passend kunstgebit, is het normaal dat er in de laatste fase steeds minder voeding en vocht wordt ingenomen. Het lichaam heeft geen behoefte meer aan eten en drinken en dat hoort bij het 
natuurlijke proces van het sterven. Meestal wordt er dan ook in de allerlaatste fase geen infuus of sonde meer gegeven. De nadelen van te veel vocht (onder andere benauwdheid) zijn groter dan die van te weinig vocht. Kunstmatige toediening van vocht en voeding verhindert het natuurlijk beloop en rekt het stervensproces onnodig.

In de besluitvorming om toediening van voedsel en/of vocht te beëindigen, moeten de wettelijk vertegenwoordiger en de naaste familie van de patiënt meebeslissen. Artsen en verpleegkundigen blijken soms tegengestelde opvattingen te hebben over het vocht- en voedingsbeleid. Een helder standpunt van het hele team is van groot belang, ook om aan de familie eenduidige informatie te kunnen geven.

\subsubsection{Pneumonie}

Van de patiënten met dementie die een pneumonie krijgen en met antibiotica worden behandeld, overlijdt rond de helft binnen zes maanden. ${ }^{6}$ In Nederland wordt in bijna een kwart van de gevallen van mensen met dementie die een pneumonie ontwikkelen, afgezien van antibiotica. Het gaat hierbij voornamelijk om de ziekste patiënten, die dan veelal binnen enkele dagen overlijden. In tegenstelling tot de situatie bij geringe inname van voeding en vocht, gaat een pneumonie gepaard met veel lijden (onder andere ernstige benauwdheid). Het is belangrijk daar alert op te zijn, zodat comfortmaatregelen (zoals frequent bij de zieke aanwezig zijn, ondersteuning bij hoesten, zorgen voor een goede houding, warme aandacht) en medicatie om pijn te bestrijden en benauwdheid tegen te gaan, het lijden kunnen verlichten.

\subsubsection{Conclusie}

Deze paragraaf ging in op enkele veelvoorkomende problemen en interventies bij de zorg voor mensen in de laatste fase van dementie. Kennis hiervan is onontbeerlijk om aan deze mensen goede zorg te kunnen verlenen.

\section{LITERATUUR}

1 Buntinx, F., J. De Lepeleire \& M. Ylieff. Zorg voor dementerenden in België: Honderd vragen en antwoorden op basis van het Qualidem-onderzoek. Garant, Leuven, 2006.

2 Meulen, A. van der \& I. Keij-Deerenberg. Sterfte aan dementie. Statistisch Kwartaalblad over de Demografie van Nederland, 2003, 51, 24-28. www.cbs.nl/NR/rdonlyres/57D8293E-8EA9-4B53B8C1-04DDEDFE1Coo/o/2003k2b15po24art.pdf.

3 Medische zorg met beleid. Handreiking voor de besluitvorming over dementerende patiënten in het verpleeghuis. NVVA, Utrecht, 1997.

4 Eliens, A.M. \& A. Kooijman. Hoe bespreek je vragen en problemen rond het levenseinde. V\&VN, Utrecht, 2008.

5 Steen, I.T. van der \& L. Deliens. End-of-life Care for Patients with Alzheimers's Disease. In: Bährer-Kohler, S. (ed.). Self Management of Chronic Disease. Springer, Heidelberg, 2009.

6 Steen, J.T. van der, G. Albers, E. Licht-Strunk, et al. Een prognostische score voor patiënten met pneumonie en dementie. Tijdschrift voor Verpleeghuisgeneeskunde, 2009, 34, 2, 66-69. 
7 Eliens, A.M. \& A. Kooijman. Zorg in de laatste levensfase. Tijdschrift voor Verpleegkundigen, 2009, $4,40-43$.

8 Kooijman, A. \& P.M.J. Vleugels. Op zoek naar evenwicht. Morele vragen voor artsen en verpleegkundigen. Kavanah, Dwingeloo, 2008.

9 Steen, J.T. van der, C.M.P.M. Hertogh \& T. de Graas (red.). Zorg rond het levenseinde voor mensen met de ziekte van Alzheimer of een andere vorm van dementie: een handreiking voor familie en naasten, VU Uitgeverij, 2011. Bewerking van: Arcand, M. \& C. Caron. Comfort care at the end of life for persons with Alzheimer's disease or other degenerative diseases of the brain. Universitaire de Gériatrie de Sherbrooke, Sherbrooke, 2005.

10 Visser, G. Dementie en palliatieve zorg in het verpleeghuis. Denkbeeld, Tijdschrift voor Psychogeriatrie, 2005, 17, 26-29.

11 Steen, J.T. van der \& M.W. Ribbe. Sterven met dementie: wat weten wij ervan? Tijdschrift voor Gerontologie en Geriatrie, 2007, 38, 288-297.

12 Zwakhalen, S.M.G. Het beoordelen van pijn bij ernstig dementerende verpleeghuisbewoners, Verpleegkunde, 2008, 4, 21-23. 


\subsection{PALLIATIEVE ZORG VOOR KINDEREN}

\section{IIse Ruysseveldt en Marleen Renard}

Kinderen die palliatieve zorg nodig hebben is een zeldzame, maar bestaande realiteit. Voor gezinnen die geconfronteerd worden met een ongeneeslijk ziek kind, is dit een complexe, emotionele en allesoverheersende gebeurtenis. Maar ook voor de betrokken zorgverleners is het zorgen voor deze kinderen een zeer intensief proces. Het is geen uitzondering dat doorgewinterde (huis)artsen en verpleegkundigen, met vele jaren ervaring, voor de eerste maal geconfronteerd worden met palliatieve zorg bij een kind.

In deze paragraaf gaan wij in op de definitie van palliatieve zorg voor kinderen, de kenmerken van de doelgroep, wat deze zorg verschillend maakt met palliatieve zorg bij volwassenen, de essentie van een goede pijn- en symptoomcontrole bij kinderen en ten slotte de vereisten waaraan deze zorg dient te voldoen.

\subsubsection{Palliatieve zorg voor kinderen: hoe te definiëren?}

De meest gangbare definities voor palliatieve zorg voor kinderen zijn van de Wereldgezondheidsorganisatie (WHO) en de Association for Children with Life-threatening or Terminal Conditions and Their Families (ACT). De definitie van de WHO luidt (vertaald) als volgt:

Palliatieve zorg voor kinderen is specifieke zorg voor kinderen, ook al is deze zeer nauw verwant met het terrein van de palliatieve zorg voor volwassenen. Palliatieve zorg voor kinderen is actieve totaalzorg van het kind, gericht op het fysieke, het psychische en het spirituele niveau, alsook de ondersteuning van de familie. Deze zorg start bij het stellen van de diagnose en duurt voort, ongeacht of het kind een behandeling ondergaat voor de vastgestelde ziekte. Zorgverleners moeten de fysieke, psychische en sociale behoeften van het kind evalueren en verlichten. Efficiënte palliatieve zorg vereist een brede multidisciplinaire benadering, die ook het gezin omvat en die gebruikmaakt van de bestaande structuren binnen de gemeenschap. De zorg kan succesvol geïmplementeerd worden, zelfs met beperkte middelen. Die kan worden verstrekt in de tertiaire zorgvoorzieningen, in wijkgezondheidscentra en zelfs bij het kind thuis.'

De (vertaalde) ACT-definitie luidt:

Palliatieve zorg voor kinderen en jongeren met levensbedreigende en/of levensbeperkende aandoeningen betreft een actieve en totale benadering van de zorg vanaf het moment van diagnose of de erkenning van de aandoening, gedurende het 
zorgtraject, tot de dood en ook daarna. Het omvat fysieke, emotionele, sociale en spirituele elementen en richt zich in het bijzonder op de verbetering van de kwaliteit van leven voor het kind/de jongere en de ondersteuning van het gezin. De zorg moet ook voorzien in het aanpakken van alle mogelijke stressfactoren, het aanbieden van ontspanningsmomenten, alsook de nodige stervens- en rouwbegeleiding. ${ }^{2}$

Beide definities hebben als voornaamste kenmerk het concept van totaalzorg, niet alleen voor de patiënt, maar evenzeer voor het gezin en de directe sociale omgeving en met aandacht voor de lichamelijke, psychosociale, pedagogische en spirituele behoeften. Omdat het zowel gaat om kinderen met levensbedreigende als om kinderen met levensverkortende condities, start palliatieve zorg bij kinderen al op het moment dat de ziekte gediagnosticeerd wordt. Het vraagt een gecoördineerde, multidisciplinaire aanpak, waar de patiënt ook verblijft. Palliatieve zorg bij kinderen is gericht op een maximum aan kwaliteit van leven, met goede pijn- en symptoomcontrole, met respect voor de keuzen van het kind en het gezin. Daarnaast is stervens- en rouwbegeleiding onderdeel van de palliatieve zorg.

Sinds 2007 is het IMPaCCT-document van betekenis voor de karakterisering van palliatieve zorg voor kinderen in Europa. ${ }^{3}$ Dit document is opgesteld door de Taskforce Palliatieve Zorg bij Kinderen van de European Association for Palliative Care (EAPC). Het document gaat in op de essentie van palliatieve zorg bij kinderen en bevat belangrijke adviezen voor pijn- en symptoomcontrole. Veel van de informatie uit onze paragraaf sluit aan en/of is ontleend aan dit IMPaCCT-document.

\subsubsection{Het aantal kinderen in de palliatieve zorg}

Concrete cijfers over hoeveel kinderen palliatieve zorg nodig hebben ontbreken, maar we weten dat de groep niet groot is. Uit epidemiologisch onderzoek is namelijk bekend dat ongeveer tussen de 8 à 10 kinderen per 10.000 in de leeftijd van 0-19 jaar een levensbedreigende aandoening hebben. ${ }^{4}$ Voor Vlaanderen zou dit concreet gaan om 960 à 1200 kinderen op jaarbasis. Voor Nederland om 1520 à 1900 kinderen.

\subsubsection{De patie̊ntengroepen}

Palliatieve zorg bij kinderen is voornamelijk gericht op vier groepen, zoals weergegeven in de uitgave van de ACT en het RCPCH:2

* $\quad$ kinderen met een levensbedreigende aandoening bij wie de curatieve behandeling faalt (bijvoorbeeld kinderen met kanker);

= kinderen met levensverkortende aandoeningen, bij wie dankzij intensieve behandelingen het leven op een kwaliteitsvolle manier aanzienlijk verlengd kan worden (onder meer kinderen met mucoviscidose);

= kinderen met progressieve aandoeningen waarvoor geen curatieve behandeling bestaat en bij wie de diagnose direct ook een palliatieve zorgfase inluidt (bijvoorbeeld kinderen met spierdystrofie of neuromusculaire aandoeningen); 
- kinderen met niet-progressieve, complexe aandoeningen, bij wie door complicaties een vroegtijdige dood mogelijk is (waaronder bepaalde vormen van cardiopathieën).

\subsubsection{Waar wordt de palliatieve zorg voor kinderen gegeven?}

Historisch gezien is palliatieve zorg bij kinderen in België vooral het domein van 'specialistische pediatrische hemato-oncologieteams'. Deze ontstonden eind jaren tachtig in eerste instantie vanuit de kinderoncologische centra. Naast de palliatieve zorg in de universitaire kinderziekenhuizen, de afdelingen kindergeneeskunde van regionale ziekenhuizen, revalidatiecentra voor kinderen, residentiële en semiresidentiële opvangvoorzieningen voor kinderen, is er in België sinds eind jaren tachtig een duidelijke tendens naar ambulante, maar vooral ziekenhuisgestuurde transmurale zorg: de specialistische zorg wordt vanuit het ziekenhuis tot bij de patiënt thuis en zijn omgeving gebracht. In tegenstelling tot Nederland zijn er in België nog geen kinderhospices en is respijtzorg in prille ontwikkeling, alternatieven die zeker een meerwaarde kunnen bieden. Als ouders en kinderen ervoor kiezen, kan de zorg thuis georganiseerd, gecoördineerd en begeleid worden zodat deze kinderen zo veel mogelijk thuis kunnen blijven en zelfs kunnen sterven (zie ook paragraaf 5.2.5).

In Nederland verlenen zorgverleners palliatieve zorg voor kinderen thuis, in (kinder-, algemene of academische) ziekenhuizen, in kinderhospices, in revalidatiecentra en instellingen voor verstandelijk gehandicapte kinderen. In de gezondheidszorg in Nederland valt de verantwoordelijkheid voor kinderen die thuis verblijven automatisch toe aan de huisarts. 5

In de palliatieve zorg voor kinderen wordt ervan uitgegaan dat thuis verzorgd worden en uiteindelijk ook sterven - indien de medische en sociale situatie dat toelaat - de voorkeur heeft. Uit internationaal vergelijkend onderzoek blijkt dat het aandeel kinderen dat thuis sterft varieert tussen landen, in België is dat bijvoorbeeld $24 \%$ en in Nederland $29 \%$. In de groep kinderen die overlijdt door een chronische ziekte, ligt het aantal thuisoverlijdens in de meeste landen een stuk hoger, bijvoorbeeld $36 \%$ in België en $50 \%$ in Nederland. ${ }^{6}$ Van de kinderen die de auteurs zelf begeleiden, sterft 75 à $80 \%$ thuis.

\subsubsection{Voorwaarden om thuis te sterven}

Als een kind palliatieve zorg nodig heeft, komt vaak de vraag om zo veel mogelijk thuis te zijn, daar zorg te krijgen en uiteindelijk thuis te sterven. Er moet naar gestreefd worden om dit mogelijk te maken. Daarvoor is een aantal voorwaarden noodzakelijk:

* continuiteit van de zorg tussen ziekenhuis en thuis;

* coördinatie van de zorg, enerzijds tussen het ziekenhuis en de zorgverleners aan huis en anderzijds tussen de “thuiszorgbegeleiders'; 
a de professionele zorgverleners dienen 24 uur bereikbaar te zijn;

- expertise en mogelijkheden voor adequate comfort- en pijntherapie;

= voldoende begeleiding, ondersteuning en informatie voor zorgverleners en gezinsleden rond de zorg van het kind;

w op ieder ogenblik kunnen terugkeren naar het ziekenhuis.

Dit betekent dat de zorgverleners in de thuisomgeving (bijvoorbeeld de huisarts en verpleegkundigen) vertrouwd moeten raken met palliatieve zorg bij kinderen, de nodige informatie moeten krijgen en bijgestaan moeten worden in het (her)kennen van en inspelen op de specifieke behoeften van kinderen in de palliatieve zorg. In België wordt naar dit model gestreefd door pediatrische liaisonteams, multidisciplinair georiënteerd, die de brug vormen tussen het ziekenhuis en thuis en hierbij een informerende, coördinerende, coachende en ondersteunde rol op zich nemen. Bovendien organiseren deze teams de zorg, stellen ze hulpmiddelen ter beschikking en hebben ze aandacht voor de financiële en psychosociale gevolgen voor de gezinnen. Er wordt hierbij zeer intensief samengewerkt met de reguliere diensten voor thuiszorg.

\subsubsection{Het specifieke karakter van de palliatieve zorg bij kinderen}

Ondanks een aantal raakpunten zijn er ook wezenlijke verschillen tussen de palliatieve zorg voor volwassenen en die voor kinderen. 4

w Palliatieve zorg bij kinderen is en blijft zeldzaam door de kleine aantallen van patiënten. De meesten van deze kinderen komen zelden of nooit terecht op de voorzieningen voor volwassen palliatieve zorg. Verpleegkundigen en andere zorgverleners in deze 'volwassen settings' hebben hierdoor weinig kans om expertise op te bouwen.

- De diagnostische diversiteit bij kinderen is niet alleen groot, maar bovendien gaat het vaak om zeldzame aandoeningen waarbij het verloop zeer onvoorspelbaar en wisselend is. Bij sommige ziektebeelden zijn mondiaal maar een paar kinderen bekend die eraan lijden, waardoor weinig of geen informatie beschikbaar is om op terug te vallen.

* Kinderen zijn geen kleine volwassenen bij wie doses van volwassenen gewoon even aangepast worden. Anderzijds moeten veel zorgverleners weerstanden overwinnen om kinderen palliatief te behandelen, bijvoorbeeld bij het opstarten van zware opioïden, het opstarten van anxiolytica en stoppen van vocht en voeding. Het zoeken naar aangepaste behandelingen, maar ook het gebruik van een goed getimede en goed afgestemde pijn- en symptoomcontrole is bij kinderen een unieke zoektocht (zie ook paragrafen 5.2.9 t/m $5.2 .11)$. 
\# De periode van palliatieve zorg verschilt vaak met die bij volwassenen. Daar waar bij volwassenen de palliatieve fase soms relatief snel kan verlopen, is er bij kinderen vaak sprake van 'chronische' palliatieve zorg.

= Alleen al door de leeftijd is het sterven van een kind tegen de natuur in. De persoonlijke impact op zorgverleners is dan ook enorm, en zal meer dan bij volwassenen in palliatieve zorg, specifieke ondersteuning en aandacht vragen.

* De rol van het gezin is veelal veel groter dan bij volwassen patiënten. In de volgende paragraaf staan we daar langer bij stil.

\subsubsection{De rol en betrokkenheid van ouders en andere gezinsleden}

In de zorg voor palliatieve kinderen zijn ouders de belangrijkste 'partners'. Afhankelijk van de leeftijd van het kind zijn de ouders in meerdere of mindere mate diegenen die beslissingen nemen, die verzorgen, verplegen, het kind ondersteunen en beschermen. De ouders bepalen heel sterk wat in de zorg wel of niet gebeurt. Zij zijn de centrale zorgverlener van hun kind en dienen als dusdanig erkend te worden. Daarnaast is het essentieel dat ze hun rol als ouder niet uit het oog verliezen en ook ten volle kunnen opnemen. Open, eerlijke en duidelijke communicatie, multidisciplinair georiënteerd, en gericht naar alle partijen - kind, ouders, broers en zussen, zorgverleners - is dan ook onontbeerlijk om het evenwicht te bewaken.

Binnen de palliatieve zorg bij kinderen zijn familiale aandoeningen geen uitzondering. Het gebeurt dat binnen één gezin meerdere kinderen getroffen worden door dezelfde erfelijke ziekte. Ouders kunnen letterlijk het gevoel hebben dat ze verantwoordelijk zijn voor wat hun kind(eren) overkomt. Dit geeft een extra emotionele belasting en heeft ook een weerslag op een eventuele kinderwens in de toekomst.

Het verliezen van een kind is een zeer extreme en ingrijpende gebeurtenis voor iedere betrokkene, maar zeker voor de ouders en andere leden van het gezin. In de palliatieve zorg voor kinderen moet dan ook veel aandacht uitgaan naar stervensbegeleiding en rouwzorg. Nazorg aan ouders, broers en zussen moet lange tijd een belangrijk aandachtspunt zijn van de zorgverleners die palliatieve zorg aan het kind hebben verleend.

\subsubsection{Vaststellen van pijn}

Een belangrijke opdracht in de palliatieve zorgverlening is een goede pijncontrole. Om tot een goed behandelingsplan te komen, zijn observatie, beoordeling en rapportering van gedrag, houding en reacties van het kind onontbeerlijk. Essentieel hierbij is dat klachten van pijn die aangegeven worden door het kind of door de ouders ernstig genomen worden.

Een goede pijnanamnese is de hoeksteen van een goede behandeling. Een anamnese gebeurt indien mogelijk bij het kind zelf, maar zeker ook bij de ouders of andere dagelijkse zorgverleners van het kind. Dit kan door het kind rechtstreeks te ondervragen, door het kind te observeren en/of door gebruik te maken van 
aangepaste pijnschalen. Het is evident dat de leeftijd van het kind zeer bepalend is voor de manier waarop men de pijnanamnese zal doen, maar ook het ontwikkelingsniveau van het kind, de interactie met zijn directe omgeving en zijn ziektegeschiedenis zijn elementen die meegenomen moeten worden in de beoordeling van de pijn bij het kind.

Onderdeel van het afnemen van een pijnanamnese, en vaak ook onderdeel van de dagelijkse zorg, is het meten van de intensiteit van de pijn. Afhankelijk van de leeftijd kan er een beroep gedaan worden op pijnschalen. Bij grote kinderen kan men gebruikmaken van dezelfde pijnschalen als bij volwassenen, zoals de VAS (visueel analoge schaal) en de VBS (verbaal beschrijvende schaal). Bij jonge kinderen maakt men gebruik van aangepaste gezichtsschalen, waarbij het gezichtje evolueert van blij naar droevig (van pijn vertrokken), al of niet met tranen, om op die manier de pijn te kwantificeren. Bij heel kleine kinderen moet vooral het gedrag geobserveerd worden, waarbij men rekening houdt met bijvoorbeeld slaappatroon, gelaatsuitdrukking, vocale reacties, lichaamsbeweging, spierspanning en ademhaling.

\subsubsection{Pijnmedicatie}

Ook bij kinderen vindt pijnbehandeling plaats door analgetica aan de hand van de pijnladder van de Wereldgezondheidsorganisatie. Als analgetica van stap 1 is paraceta$\mathrm{mol}$ in een dosering van $20 \mathrm{mg} / \mathrm{kg} /$ dosis eerste keus. Als dit niet toereikend is, voegt men NSAID's toe. NSAID's hebben een anti-inflammatoir of anti-ontstekingseffect en kunnen zeker van nut zijn bij botpijnen. Als analgeticum van stap 2 (zwakke opioïden) wordt bij kinderen vooral tramadol gebruikt, zowel per os als intraveneus. Via een pijnpompje kan tramadol intraveneus toegediend worden in een continu infuus met eventueel extra bolustoedieningen bij doorbraakpijn. Wanneer de maximale dosis tramadol niet volstaat, wordt er overgeschakeld naar een analgeticum van stap 3 (sterke opiöden), bij kinderen meestal morfine, in een perorale of transdermale dosering of indien mogelijk intraveneus.

Een belangrijk element is de toedieningsvorm van de medicatie. Vaak is het innemen van medicatie via de mond een probleem en het geven van medicatie intrarectaal is niet altijd geschikt. Subcutane toediening brengt voor veel kinderen ongemak met zich mee. Daarom wordt, indien er een goede toegangsweg aanwezig is, vaak snel overgegaan tot het intraveneus toedienen van medicatie via een pijnpomp.

In de palliatieve zorg bij kinderen wordt morfine niet alleen gegeven bij hevige pijn, maar ook bij discomfort, angst, dyspnoe en ademhalingsproblemen, maar dan wel in een aangepaste lage dosis. Bij jonge kinderen wordt er meestal kortwerkende morfine gegeven in de vorm van siroop of zetpillen. Bij grotere kinderen kan men, zoals bij volwassenen, gebruikmaken van morfinetabletten met vertraagde afgifte. Vanaf een lichaamsgewicht van 5 kilogram kan men gebruikmaken van een fentanylpleister. Voor adequate doseringen van pijnmedicatie bij kinderen kunnen we verwijzen naar het Oxford Textbook of Palliative Care for Children.? 
Het is evident dat men ook de ouders informeert over de mogelijke bijwerkingen van de medicatie en dat men probeert te anticiperen op mogelijke neveneffecten. Communicatie blijft ook hier het sleutelwoord. Comfort van het kind moet prioriteit hebben, ondanks de vooroordelen en weerstanden die er vaak bestaan bij het opstarten van medicatie. Het starten van vooral opiaten is voor de naasten vaak een signaal van de achteruitgang van het kind. Dit is voor de familie die nauw betrokken is in de zorg van het kind zeer vaak een moeilijk te nemen stap.

\subsubsection{Ondersteunende medicatie (coanalgetica)}

Coanalgetica worden net zoals bij volwassenen ook in de palliatieve zorg bij kinderen gebruikt. Corticosteroïden vormen een voorbeeld van coanalgetica. Deze middelen zijn zeker aangewezen voor het behandelen van botpijnen, maar ook voor het aanpakken van symptomen van overdruk bij kinderen met hersentumoren (een kwart van de kinderen met een oncologisch proces heeft deze tumoren). Corticosteroïden kunnen eveneens een gunstig effect hebben op misselijkheid en braken.

Antidepressiva en anti-epileptica kunnen ook als coanalgetica gebruikt worden. Pijn ten gevolge van polyneuropathie (zenuwontstekingen) is moeilijk te behandelen met de primaire analgetica. Een antidepressivum (bijvoorbeeld amitriptyline) of een antiepilepticum (bijvoorbeeld carbamazepine of gabapentine) kan dan overwogen worden.

Ook anxiolytica of sedativa, meestal van de groep van de benzodiazepinen (bijvoorbeeld diazepam of midazolam), worden soms gebruikt in de palliatieve zorg voor kinderen, vooral bij angst en onrust. Dit soort middelen kunnen oraal, via een maagsonde, rectaal of intraveneus toegediend worden. De benzodiazepinen hebben ook een anti-epileptische werking en worden soms gegeven bij kinderen met een neurologische aandoening of bij kinderen met een hersentumor, bij wie een epilepsieaanval dreigt. Benzodiazepinen kunnen ook ontspanning geven en de pijn verzachten bij spierpijnen, krampen en spasticiteit, naast het gebruik van een spasmolyticum (zoals baclofen).

Neuroleptica of antipsychotica (zoals haloperidol) worden vaak gebruikt bij psychosen en bij een aantal andere ziektebeelden waarbij hallucinaties, delirium of psychomotorische agitatie bestaan. Sommige neuroleptica (zoals largactil) kunnen ook aangewend worden als middel tegen misselijkheid en braken van neurologische oorsprong.

Voor informatie over doseringen van coanalgetica bij kinderen in de palliatieve fase, verwijzen we opnieuw naar het Oxford Textbook of Palliative Care for Children. ${ }^{7}$

\subsubsection{Benauwdheid}

In de palliatieve fase spelen vaak meerdere belastende symptomen, die in dit boek niet allemaal behandeld kunnen worden. In het kader van symptoomcontrole vereist dyspnoe (kortademigheid) echter speciale aandacht, omdat dit zowel bij het kind als bij de ouders vaak gepaard gaat met veel angst en stress. Zuurstoftherapie en een lage dosis morfine en eventueel een lage dosis van een benzodiazepine kan comfort 
bieden en de angst verminderen. Vooral bij kinderen met snelle achteruitgang, zoals jonge kinderen met neuromusculaire aandoeningen of patiënten met de ziekte van Duchenne, kan dit spelen.

Wanneer het kind veel secreties heeft en moeilijk ophoest, is het wenselijk om (ook thuis) voor een aspiratietoestel te zorgen. Speekselvloed kan ondervangen worden door het opstarten van een anticholinergicum (bijvoorbeeld glycopyrroniumbromide per os of via een maagsonde).

\subsubsection{Comfortinterventies en ontspannende activiteiten}

Naast de medicamenteuze behandeling van pijn en discomfort kunnen ook nietmedicamenteuze interventies aangewend worden, zoals massage of ontspanningsoefeningen (zie ook paragraaf 4.5). Ook afleiding door spel, muziek en voorlezen zijn vaak zeer zinvolle activiteiten die kunnen bijdragen aan het comfort voor de patiënt, maar ook voor de ouders en de onmiddellijke orngeving. Het is dikwijls de directe omgeving van het kind die ons hier kan helpen. Zij kennen de voorkeuren van het kind. Ook de school kan hier een rol spelen, net zoals een bezoek van vriendjes of familie.

Belangrijk is dat men het kind en het gezin stimuleert om zo lang mogelijk een 'normaal leven' te leiden. Dit is dikwijls ook de wens van het kind zelf, zeker wanneer het lange ziekenhuisopnamen achter de rug heeft. De ouders, familie, de omgeving stimuleren om ontspannende activiteiten (bijvoorbeeld uitstapjes) aan te bieden en te organiseren is een taak die weggelegd is voor het ondersteunende team. Uit ervaring blijkt dat dit soms veel rust en ook later veel troost geeft.

\subsubsection{Communicatie met kinderen over ziekte en prognose}

Praten met kinderen en jongeren over hun ziekte start niet op het moment dat ze palliatief worden, maar dient vanaf de diagnose te gebeuren, gedurende het hele zorgtraject en zal mede bepaald worden door de leeftijd, het ontwikkelingsniveau, het karakter en het tempo van het kind. Hoe graag ouders dit ook willen, ze kunnen hun kind niet afschermen van datgene wat hem/haar overkomt. Ook niet van het feit dat genezen niet meer mogelijk is.

Wanneer een kind palliatief wordt, zal dan ook in eerste instantie met de ouders overlegd worden, wat aan het kind verteld wordt en door wie. Ouders dienen inzicht te krijgen in hoe kinderen denken en voelen over sterven en dood, hoe hun kind hiernaar kijkt. Ze dienen vaak aangemoedigd te worden om informatie aan hun kind te geven. De angst voor een emotioneel, totaal ontredderd kind kan groot zijn. Maar helemaal niet praten kan juist diezelfde ontreddering bij het kind teweegbrengen. Er wordt naar gestreefd om het kind precies die informatie te geven die het nodig heeft om de veranderingen te kunnen begrijpen, rekening houdend met de taal, het niveau, het tempo van het kind en met respect voor de keuzen die de ouders, maar ook het kind maken. Het kind is vaak veerkrachtig genoeg om zelf de weg aan te 
geven die het wenst te gaan, maar zal zich ook heel loyaal opstellen ten opzichte van zijn/haar ouders. Voor ouders is het belangrijk deze mechanismen te begrijpen, hun kind goed te observeren en te luisteren naar wat het beroert. En dit in een sfeer van openheid, veiligheid en geborgenheid, waar veel kan, maar weinig hoeft.

Als zorgverlener is het belangrijk ouders te informeren, te ondersteunen in de ouderrol, rust en veiligheid aan te reiken, alert te zijn voor datgene wat in het gezin gebeurt en hier oprecht en eerlijk over te communiceren.

\subsubsection{Communicatie en afstemming tussen zorgverleners}

Communicatie met alle betrokken zorgverleners (inclusief de mantelzorgers) is cruciaal voor goede palliatieve zorg. Wensen en prioriteiten van zorgverleners lopen niet altijd gelijk. Het is de taak van het coördinerend team of de coördinerende zorgverlener om eerst en vooral goed te luisteren naar iedereen en tot een consensus te komen, met als topprioriteit het maximale comfort van het kind.

Dit is vaak een moeilijke en energieverslindende taak en de kunst bestaat erin om in kleine stappen te werken. Het achteruitgaan van een toestand van een ziek kind wordt vaak als onnatuurlijk en onaanvaardbaar ervaren en dit uit zich op vele vlakken, ook in het (niet) aanvaarden van comfortzorg. Het is de taak van coördinerende zorgverleners om daarop te wijzen en als advocaat van het kind op te treden, maar met alle begrip voor ieder die de zorg opneemt voor het kind.

ledereen die betrokken wordt in de zorg voor een ernstig ziek kind zal vroeg of laat geconfronteerd worden met gevoelens die gaan over de essentie van het leven, de zingeving van alles, met andere woorden existentiële gevoelens en vragen. Dit kan tot verwarring en twijfel leiden, maar ook tot een diepe verbondenheid. Het sterven van een kind mag geen taboe zijn. In deze hoogtechnologische tijd, waar alles mogelijk lijkt, is het heengaan van een jong persoon voor veel zorgverleners moeilijk te aanvaarden en daardoor ook moeilijk bespreekbaar. We moeten er ons van bewust zijn dat ondanks de vele kennis en kunde, onze wetenschap eindig is en dat we op een bepaald punt het onvermijdelijke moeten aanvaarden. Verbondenheid met de patiënt, maar ook met andere zorgverleners, maakt dit lijden beter te verdragen.

\subsubsection{Conclusie}

Palliatieve zorg bij kinderen is een intense samenwerking tussen vele partijen: het kind zelf, ouders, broers en zussen, zorgverleners uit de eerste en de tweede lijn. Verpleegkundigen en andere zorgverleners moeten beseffen dat het kind centraal staat in de zorg. Het streven is optimale levenskwaliteit, met respect voor de keuzen die het kind en zijn omgeving maken. Daarbij moeten we niet uit het oog verliezen dat - ook bij kinderen - palliatieve zorg vooral een wijze is van aanwezig zijn, van luisteren, meevoelen, meeleven en tijd nemen. Binnen het hele zorgtraject blijft communicatie met alle partners (ouders, zorgverleners, ouders en andere gezinsleden) betrokken in de zorg voor het kind een sleutelwoord. 


\section{LITERATUUR}

1 Sepulveda, C., A. Marlin, T. Yoshida \& A. Ullrich. Palliative care: The World Health Organization's global perspective. Journal of Pain and Symptom Management, 2002, 24, 91-96.

2 Association for Children with Life-threatening or Terminal Conditions and Their Families (ACT) en Royal College of Paediatrics and Child Health (RCPCH). A Guide to the Development of Chil dren's Palliative Care Services. Bristol, 2003.

3 Craig, F., H. Abu-Saad Huijer, F. Benini, et al. IMPaCCT: standards of paediatric palliative care. European Journal of Palliative Care, 2007, 14, 109-114.

4 Lenton, S., A. Goldman, N. Eaton \& D. Southall. Development and epidemiology. In: Goldman, A., R. Hain \& S. Liben (eds.). Oxford Textbook of Palliative Care for Children. Oxford University Press, Oxford, 2006.

5 Molenkamp, C.M., H. Huijer Abu-Saad \& J.P.H. Hamers. Palliatieve zorg voor kinderen in Nederland. Zorgbehoeften, zorgaanbod en knelpunten: een 'quick scan'. Centre for Nursing Research, Universiteit Maastricht, 2002.

6 Pousset, G., J. Bilsen, J. Cohen, et al. Deaths of children occurring at home in six European countries. Joumal for Child Care and Health Development, 2010, 36, 375-384.

7 Goldman, A., R. Hain \& S. Liben (eds.). Oxford Textbook of Palliative Care for Children. Oxford University Press, Oxford, 2006. 


\subsection{PALLIATIEVE ZORG VOOR MENSEN MET EEN NIET-WESTERSE ACHTERGROND}

\section{Anneke Francke en Fuusje de Graaff}

Mensen met een niet-westerse achtergrond zullen de komende decennia een steeds groter beroep doen op palliatieve zorg. De vergrijzing is daar voor een groot deel debet aan, hoewel de vergrijzing bij allochtone groepen minder snel gaat dan bij autochtone groepen.

In Nederland waren er in 19981,2 miljoen niet-westerse allochtonen en dat zullen er in 2015 ongeveer 2 miljoen zijn. Turken, Marokkanen en Surinamers vormen in Nederland de grootste groepen niet-westerse allochtonen. Het percentage 65-plussers zal binnen die allochtone groepen in de periode 1998-2015 meer dan verdubbelen: van $3 \%$ in 1998 tot ongeveer $7 \%$ in $2015 .{ }^{1}$

In Vlaanderen leven nu circa 40.000 allochtone senioren. Tegen $2015 \mathrm{zal}$ het aantal Italiaanse 6o-plussers met $227 \%$ toenemen. De groep Marokkaanse 6o-plussers zal zelfs met $311 \%$ groeien. Bij de allochtonen met Turkse wortels zal het aantal senioren met $314 \%$ toenemen. ${ }^{2}$

Het wordt door het stijgende aantal mensen met een niet-westerse achtergrond steeds belangrijker dat verpleegkundigen en andere zorgverleners hun palliatieve zorg afstemmen op cultureel bepaalde zorgbehoeften en communicatiepatronen van mensen afkomstig uit niet-westerse culturen. Tegelijkertijd moet men er rekening mee houden dat de verscheidenheid onder immigranten groot is en dat hun culturele bagage niet alleen bepaald wordt door het land van herkomst, maar ook door opleiding, economisch vermogen, sociale setting en eerdere ervaringen in Nederland en Vlaanderen.

\subsubsection{Communicatie over ziekte en prognose}

Westerse zorgverleners spreken vaak redelijk open over een slechte prognose. Niet alle patiënten zijn daar altijd even blij mee, maar de meeste Nederlandse en Vlaamse patiënten accepteren die openheid omdat ze dan beter kunnen meedenken over eventuele behandelopties en actief persoonlijke keuzen kunnen maken. Bij immigranten met een niet-westerse achtergrond (lees in dit geval: mensen afkomstig uit Azië, Afrika, Zuid-Europa of Zuid-Amerika) ligt dat meestal anders. ${ }^{3-8}$ Open en directe communicatie over bijvoorbeeld het ongeneeslijke karakter van een ziekte is bij de eerste generatie immigranten nog steeds een taboe, bijvoorbeeld vanuit de gedachte 'daar spraken we in ons land niet over' of 'ons lot is in handen van Allah/God' en 'we zullen pas sterven als onze tijd gekomen is'. De aankondiging van de zorgverlener dat de betrokkene 'niet meer zal genezen' kan dan kwetsend en shockerend zijn. 
In de communicatie speelt ook een rol dat zorgverleners veelal een onderscheid zien tussen curatieve en palliatieve zorg, terwijl dat voor patiënten en familie vaak niet zo duidelijk is. Zorgverleners maken in de palliatieve fase het liefst samen met de patiënt een afweging tussen de baten en lasten van een behandeling en stellen daarbij vaak de kwaliteit van leven voorop. Allochtone patiënten kunnen zich echter vaak geen beeld vormen van de biomedische processen waarop westerse zorgverleners hun uitspraken baseren, en mede daardoor vinden zij het onderscheid tussen curatieve en palliatieve zorg meestal niet relevant. Sommige patiënten willen het onderscheid niet maken vanwege hun geloofsovertuiging. Zo beroepen veel moslims zich op de plicht in de islam om goed voor het lichaam te zorgen en te blijven streven naar genezing. Ook deze verschillende perspectieven (nadruk op kwaliteit van leven versus nadruk op levensverlenging) bemoeilijken soms de communicatie.

Verpleegkundigen vinden het daarbij soms ook lastig als ze niet rechtstreeks met de patiënten kunnen communiceren. Mensen met een niet-westerse achtergrond zijn vaak gewend zich meer als groepslid dan als individu op te stellen. De patiënten zullen zich in deze fase vaak laten vertegenwoordigen door familieleden. Taalbarrières spelen dikwijls ook een rol om een familielid die de taal wel goed spreekt als aanspreekpunt naar voren te schuiven. ${ }^{9}$ Sommige familieleden stellen zich vooral als tolk van de patiënt op, andere zijn ook duidelijk de belangenbehartiger van de patiënt. Zorgverleners vinden het vaak lastig als ze uitsluitend via een familielid met de patiënt kunnen communiceren. Toch is het ook in een dergelijke situatie van belang om - als het kan door navraag rechtstreeks bij de patiënt, dan wel via de familie - erachter te komen wat de wens is van de patiënt.

Vaak is het ook de familie die aangeeft dat de patiënt niet geïnformeerd mag worden over het ongeneeslijke karakter van de ziekte. Daarbij is het nodig om bij de familie na te gaan wat de motivatie is om de patiënt niet te informeren. Of er open gecommuniceerd kan worden met de familie zelf, wisselt. Te direct taalgebruik kan de communicatie soms lam leggen, ook bij de familie. Stapsgewijze informatie kan men vaak beter verdragen dan het geven van een slechte boodschap in één keer. Overigens zijn er ook patiënten (vooral onder vluchtelingen) die elke steun van familie ontberen. Ook dan is het van groot belang om - meestal met gebruik van een formele tolk - na te gaan wat de wensen van de patiënt zijn.

De beperkte bespreekbaarheid van slechte prognoses en het naderende overlijden staan op gespannen voet met dominante principes in de Nederlandse en Vlaamse gezondheidszorg als het recht op informed consent en het belang dat zorgverleners hechten aan advance care planning (zie ook paragraaf 1.1). Als de familie erop staat dat de patiënt niet geïnformeerd mag worden, moet de betrokken zorgverlener vragen wat daarvoor de motivatie is.

Uit recent onderzoek weten we dat een deel van de zorgverleners het behoud van een goede relatie met patiënt en familie zwaar laat wegen en om die reden soms 
meegaat in het verzoek om niet open met de patiënt te communiceren. ${ }^{9}$ In andere gevallen laten zorgverleners vooral zorginhoudelijke argumenten meewegen, in de zin van schaadt het de gezondheid als iemand niet volledig geïnformeerd is? Zorgverleners zullen daarin een keuze moeten maken die zo veel mogelijk recht doet aan de wensen van patiënt en familie, en die ook de gezondheid en kwaliteit van leven niet schaadt.

\subsubsection{Uiten van pijn en andere klachten}

Patiënten die pijn hebben, uiten dit op verschillende manieren. Dit wordt mede beïnvloed door de culturele waarden; leeft men in een cultuur waar het wenselijk wordt geacht om pijn 'te verbijten' of maakt men deel uit van een cultuur waarin het juist normaal wordt gevonden om pijn en ander lichamelijk ongemak (bijvoorbeeld jeuk en misselijkheid) heftig te uiten? Over het algemeen uiten mensen uit niet-westerse culturen pijn of andere lichamelijke klachten heftiger dan mensen uit West-Europa. ${ }^{10}$ Daarnaast is bekend dat mensen ervaringen van pijn of (doods)angst vaak verbinden met hun ervaringen in het verleden; eventuele ontberingen en onverwerkte trauma's beïnvloeden de klachtenpresentatie van migranten en vluchtelingen.

Taalbarrières kunnen hevige, non-verbale uitingen van pijn en ander ongemak nog versterken; als men minder in staat is klachten mondeling aan zorgverleners kenbaar te maken, kan dit bijvoorbeeld tot uiting komen in veel jammeren of kermen. Omdat de uiting soms veel expressiever is dan bij autochtone patiënten, kan het voor zorgverleners moeilijk zijn om de ernst van de klachten in te schatten.

Numerieke meetinstrumenten om klachten te meten zijn soms niet geschikt voor mensen met een niet-westerse achtergrond. Dit kan te maken hebben met gebrekkige taalbeheersing, maar ook met de moeite die men heeft om pijn of andere klachten in een getal uit te drukken. ${ }^{6}$ Maar net als bij autochtone patiënten geldt dat ${ }^{5}$ pijn of ander ongemak is dat wat de patiënt zegt dat het is'. Daarom zal een zorgverlener moeten blijven proberen om - als het kan door rechtstreekse navraag bij de patiënt of anders via de farnilie - de aard, intensiteit en beleving van pijn of ander ongemak te achterhalen.

\subsubsection{Lichamelipk verzorging}

Bij de lichamelijke verzorging van vooral de intieme lichaamsdelen spelen, zeker bij mensen uit een islarnitische cultuur, vaak schaamtegevoelens. De patiënt wast het liefst zichzelf. Als dit niet mogelijk is, zal een patiënt veelal het liefst gewassen willen worden door een familielid. Als dat niet mogelijk is, zal een mannelijke patiënt vaak door een mannelijke zorgverlener, en een vrouw door een vrouwelijke zorgverlener gewassen willen worden.

Belangrijk is dat de wensen en gebruiken van de patiënt ten aanzien van zijn lichaamsverzorging op tijd besproken worden en dat er naar mogelijkheden gezocht wordt om hieraan tegemoet te komen. ${ }^{6}$ 


\subsubsection{Medicatie}

Mensen die zich geen beeld kunnen vormen van de werking van geneesmiddelen op het functioneren van hun gestel, hebben vaak tegenstrijdige verwachtingen van de mogelijkheden van pijnmedicatie. Hoewel velen pijnbestrijding wensen, kunnen ze bij (vaak tijdelijke) bijwerkingen snel denken dat de medicijnen niet helpen of juist extra klachten geven. Dit kan tot gevolg hebben dat de patiënt stopt met de inname van de medicatie en dat hij het vertrouwen in zorgverleners verliest. Voor verpleegkundigen betekent dit dat zij hier aandacht aan moeten besteden. Zij dienen in te gaan op de werking en ook op mogelijke bijwerkingen en in hoeverre deze na verloop van tijd minder worden. ${ }^{6}$

Patiënten en familie kunnen veel moeite hebben met het feit dat opiaten soms suf kunnen maken. Mensen met een moslimachtergrond vinden het bijvoorbeeld veelal belangrijk dat de zieke vlak voor het sterven helder genoeg is om afscheid te nemen van zijn geliefden, en hen kan vergeven. Vaak komen familieleden en bekenden de laatste dagen veel op bezoek. Men wil ook dat de stervende helder voor Allah verschijnt om verantwoording af te leggen voor de daden op aarde. Om die redenen wordt ook diepe palliatieve sedatie vaak geweerd.

Voorzichtigheid met gebruik van opiaten of sedativa hangt bovendien samen met de angst dat zorgverleners medicijnen toedienen die het sterven bespoedigen. Moslims, maar ook veel migranten met bijvoorbeeld een christelijke of hindoe-overtuiging, zijn van mening dat men niet zelf het sterven mag bespoedigen.

\subsubsection{Voeding en vasten}

Het geven van voedsel aan een zieke is vaak een symbool van zorgzaamheid en liefde. Bij mensen bij wie de gemeenschap waar zij deel van uitmaken heel belangrijk is, speelt eten in die zin ook een grotere rol dan bij de meer als individu gesocialiseerde Nederlandse en Vlaamse zorgverleners. Het kan dan ook voorkomen dat zorgverleners soms met verbazing aanschouwen dat zelfs nog op het sterfbed geprobeerd wordt om patiënten te laten eten of drinken.

Bij mensen uit een moslimcultuur kan in het begin van de palliatieve fase soms nog een behoefte bestaan om mee te doen aan de ramadan, ondanks het feit dat ernstig zieke mensen en ouderen vrijgesteld zijn van de plicht tot vasten. Het is voor ernstig zieken niet zonder risico om te vasten, het kan uitdroging tot gevolg hebben, evenals een verstoring van de bloedsuikerwaarden, vermoeidheid en een verslechtering van cognitieve functies. Ook kan het gevolgen hebben voor de medicatie-inname. Aan de andere kant kan meedoen aan de ramadan ook een positief effect hebben op het psychisch welbevinden. Als het niet duidelijk is in hoeverre het vasten een nadelig effect zal hebben op de gezondheid, is het van belang de mening van de arts hierover te vragen. ${ }^{6}$ 


\subsubsection{Rol van religie bij omgaan met ziekte en overlijden}

Hoe men (ongeneeslijke) ziekte duidt, is sterk afhankelijk van de religieuze achtergrond. Zo is bekend dat mensen die het hindoegeloof aanhangen (zoals een deel van de Surinaamse Hindoestanen in Nederland), geloven in reïncarnatie, en ziekte veelal zien als een gevolg van de eigen daden in een vorig leven. Ook Surinaamse Creolen geloven vaak in reïncarnatie, maar zij associëren deze minder met daden uit een vorig leven. Bij Creolen speelt winti (een natuurgodsdienst) vaak een belangrijke rol in de betekenisverlening. Zij geloven dat alles in het leven, dus ook ziekte, een bovennatuurlijke betekenis heeft, vanaf de geboorte tot het moment van overlijden.

Bij mensen uit een moslimcultuur speelt de religieuze betekenis van de ziekte vaak ook een duidelijke rol. Ziekte wordt gezien als een soort test of beproeving van Allah. Ook associëren moslims ziekte soms met onzuiverheid of met een bestraffing door Allah. ${ }^{6}$ Moslims geloven, zoals ook migranten met een christelijke achtergrond, in een leven na de dood. Een stervende wordt geholpen door hem niet alleen te laten en door alles wat goed was in zijn leven in herinnering te roepen. Bij moslims worden de overledenen na het overlijden vaak onder leiding van een imam gewassen. De hulp van een verpleegkundige is daarbij veelal niet nodig. Daarna wordt er voor de dode gebeden en wordt hij naar de moskee of een andere reine plaats gebracht. De begrafenis moet zo snel als mogelijk plaatsvinden, vaak ook in het land van herkomst.

Het is wenselijk dat verpleegkundigen op de hoogte zijn van deze rituelen en gebruiken rondom overlijden en begrafenis, zodat zij niet overrompeld worden door alle hectiek en - war gewenst - de familie kunnen ondersteunen bij allerlei zaken die geregeld moeten worden.

\subsubsection{Conclusie}

Zorgopvattingen en zorggebruiken van migranten worden vaak mede bepaald door cultuur en religie. Kennis over verschillende culturen en religies en besef van de eigen culturele bagage kunnen verpleegkundigen helpen om in de zorgverlening keuzen te maken en soms ook af te wijken van wat gebruikelijk is in de zorg of in de communicatie met patiënten. Van verpleegkundigen kan echter niet verwacht worden dat ze alle details weten van niet-westerse culturen. Bovendien zijn er binnen één cultuur allerlei individuele verschillen tussen mensen.

Een open houding, het stellen van vragen en het aangaan van de dialoog met patiënt en naasten in de familie zijn daarom cruciaal. Deze vaardigheden zijn overigens niet alleen nodig voor goede palliatieve zorg aan mensen met een niet-westerse achtergrond, maar voor goede 'zorg op maat' bij alle patiënten. ${ }^{3}$ 


\section{LITERATUUR}

1 Alders, M.P.C. Allochtonenprognose 1998-2015. Maandstatistiek van de bevolking, 1999, 47, $20-36$.

2 www.vmc.be/detail.aspx?id=4344, website van Vlaams Minderheden Centrum. Geraadpleegd op 7 juni 2010.

3 Interculturele palliatieve zorg. Vraaggericht en individueel. Achtergrondinformatie, adviezen en tips voor zorgondernemers, managers en zorgverleners. ActiZ, Utrecht, 2009.

4 Graaff, F.M. de \& A.L. Francke. Tips voor terminale thuiszorg voor Turkse en Marokkaanse ouderen. NIVEL, Utrecht, 2002.

5 Graaff, F.M. de, T. van Hasselt \& A.L. Francke. Thuiszorg voor terminale Turkse en Marokkaanse patiënten, ervaringen en opvattingen van naasten en professionals. NIVEL, Utrecht, 2005.

6 Koppenol-van Hooijdonk, M. Palliatieve zorg. In: Neef, J.E. de, J. Tenwolde \& K.A.A. Mouthaan (red). Handboek Interculturele zorg. Elsevier/De Tijdstroom, Maarssen, 2002, III 2.19:1-31.

$7 \mathrm{Hal}, \mathrm{G}$. van, J. Fraeyman, G. Hannes, et al. Bekendheid van palliatieve zorg bij mensen die in armoede leven en allochtonen. Een kwalitatief onderzoek bij intermediairen. Onderzoeksrapport in het kader van het vak Leeronderzoek 2008-2009. Faculteit Politieke en Sociale Wetenschappen, Antwerpen, 2009.

8 Signaleringscommissie Kanker. Allochtonen en kanker. Sociaal-culturele en epidemiologische aspecten. KWF Kankerbestrijding, Amsterdam, 2006.

9 Graaff, F.M. de, A.L. Francke, M. van den Muijsenbergh \& J.D.M. van der Geest. Communicatie en besluitvorming in de palliatieve zorg aan oncologische patiënten met een Turkse of Marokkaanse achtergrond. AISSR, Amsterdam, 2010.

10 Driessen, H. Cultureel-antropologische beschouwingen over allerlei aspecten van pijn. Wereldbibliotheek, Amsterdam, 2002. 


\subsection{PALLIATIEVE ZORG VOOR MENSEN MET EEN VERSTANDELIJKE BEPERKING}

\section{Anke de Veer, Marja Oud en Anneke Francke}

Verpleegkundigen die in de verstandelijk gehandicaptenzorg werken, krijgen ook te maken met palliatieve zorg. In Nederland overlijden in een gemiddelde organisatie voor mensen met een verstandelijke beperking per jaar circa vier cliënten na een langdurig ziekbed. ${ }^{1}$ Ruim twee derde van hen is ouder dan 50 jaar. Over een periode van twee jaar bezien, krijgen naar schatting vier van de tien verpleegkundigen werkzaam in Nederland in de zorg voor mensen met een verstandelijke handicap te maken met een cliënt die na een ziekbed overlijdt. ${ }^{2}$ Voor Vlaanderen zijn er (nog) geen specifieke cijfers hierover bekend, maar ook Vlaamse verpleegkundigen werkzaam in de verstandelijk gehandicaptenzorg zullen regelmatig geconfronteerd worden met cliënten die langdurig ziek zijn en palliatieve zorg nodig hebben.

De kans dat een verpleegkundige met palliatieve zorg te maken krijgt, hangt samen met de werksetting. Omdat steeds meer mensen met een verstandelijke beperking in een kleinschalige woonvoorziening in een gewone woonwijk leven, worden ook wijkverpleegkundigen en huisartsen vaker betrokken bij de palliatieve zorg voor deze mensen. Dus verpleegkundigen buiten de verstandelijk gehandicaptenzorg zullen in toenemende mate palliatieve zorg geven aan mensen met een verstandelijke beperking.

Voor verpleegkundigen is het belangrijk te beseffen wat deze palliatieve zorg anders maakt.

\subsection{T Specifieke problemen}

Het eerste dat palliatieve zorg bij mensen met een verstandelijke beperking anders maakt, is dat zij vaak bijkomende stoornissen hebben zoals epilepsie, motorische problemen, reflux van maagzuur, problemen met horen of zien, en psychiatrische en gedragsproblemen. Zo komen autisme en aan autisme verwante stoornissen relatief vaak voor bij mensen met een verstandelijke beperking.

Op oudere leeftijd lijkt het risico op verouderingsaandoeningen ongeveer hetzelfde te zijn als in de algemene bevolking. Maar omdat deze boven op de reeds bestaande aandoeningen komen, zijn de beperkingen vaak relatief ernstig en lijden velen aan meerdere ernstige beperkingen tegelijk. ${ }^{3} \mathrm{Bij}$ sommige syndromen is er een verhoogd risico op gezondheidsproblemen op latere leeftijd. Zo hebben volwassenen met het downsyndroom vanaf de leeftijd van 30 jaar een verhoogd risico op problemen met horen en zien en vanaf 50 jaar is er een hogere kans op dementie. Deze multimorbiditeit maakt de palliatieve zorg extra complex. 


\subsubsection{Praten met de cliënten}

Zorgverleners die zich inzetten voor palliatieve zorg moeten zich bewust zijn van het ontwikkelingsniveau van de cliënten en de wijze waarop zij kunnen communiceren met de cliënt (zie ook de casusbeschrijving in paragraaf 5.4.7). Onderstaande beschrijving biedt een globale indicatie van het ontwikkelingsniveau en wat dat betekent voor de mogelijkheden om over dood en doodgaan te praten.

Mensen met een lichte verstandelijke beperking hebben een ontwikkelingsleeftijd vergelijkbaar met die van een 7/8- tot 12-jarige. ${ }^{4} \mathrm{Zij}$ zijn zich bewust van wat ongeneeslijke ziekte en doodgaan betekenen, en over het algemeen kunnen zij daarover praten, zij het op een kinderlijke manier.

Dat is anders bij mensen met een matige verstandelijke beperking, bij wie de ontwikkelingsleeftijd $4 / 5$ tot $7 / 8$ jaar is. Zij hebben een beperkt besef van wat het betekent om ongeneeslijk ziek te zijn. Voor sommigen is de dood niet onomkeerbaar. Ze zoeken naar logische verklaringen over de dood. Ze zijn kwetsbaar omdat ze niet goed met alle informatie en emoties kunnen omgaan.

Mensen met een ernstige verstandelijke beperking hebben een ontwikkelingsleeftijd tussen ongeveer 2 en $4 / 5$ jaar. Ze weten vaak niet wat de dood inhoudt en zien deze soms als iets tijdelijks. Ze zijn beperkt in hun taal en taalbegrip maar kunnen vaak wel vragen stellen over het wat, hoe en waarom. Fantasie en werkelijkheid lopen door elkaar heen.

Zeer ernstig verstandelijk beperkten hebben een ontwikkelingsleeftijd tussen o en ongeveer 2 jaar. Zij leven in het hier en nu en communiceren voornamelijk nonverbaal. Het is moeilijk na te gaan wat zij van hun ziekte en het naderende overlijden begrijpen.

Familie en begeleiders zijn een belangrijke bron van informatie. Maar er zijn ook allerlei mogelijkheden en hulpmiddelen om met de cliënt te praten over zijn of haar situatie. Zo zal de verpleegkundige meer moeten letten op de lichaamstaal van de cliënt en zelf daar ook meer gebruik van moeten maken (houding, aanraken, intonatie, mimiek).

Pictogrammen of plaatjes die situaties en emoties uitdrukken kunnen de verpleegkundige soms helpen in het contact met cliënten met een matige of ernstige verstandelijke beperking. Een zogenoemd (laatste) wensenboek kan bij hen ook een goed hulpmiddel zijn om een gesprek aan te gaan over dood en doodgaan. Het geeft een houvast om te praten over wat de cliënt fijn vindt, nog graag wil doen, en hoe de cliënt afscheid wil nemen. Ook wensen ten aanzien van de uitvaart kunnen daarmee ter sprake worden gebracht. In de zogenoemde rouw- of troostkoffer zitten foto's en (prenten)boeken die het proces van verwerken laten zien. ${ }^{5}$ Zo beeldt een serie foto's uit wat er gebeurt als de overleden persoon begraven wordt. Voor de begeleiders bevat de rouwkoffer handvatten om met de cliënt te communiceren (zoals pictogrammen en foto's). 


\subsubsection{Uiten van pijn en andere lichamelijke klachten}

Barrières in taal en begrip zorgen er ook voor dat pijn en lichamelijke klachten vaak moeilijk te herkennen zijn. De kennis over pijn bij mensen met een verstandelijke beperking is vaak beperkt. Onduidelijk is of de pijngevoeligheid hetzelfde is als bij mensen zonder verstandelijke beperking. Bijvoorbeeld bij beschadigingen van bepaalde hersengebieden komen pijnprikkels niet goed in de hersenen aan. Ook het pijngedrag kan anders zijn. Mensen met een matige of (zeer) ernstige verstandelijke beperking uiten hun pijn en klachten vaak op een andere manier. Pijnsignalen kunnen moeilijk te onderscheiden zijn van andere signalen, zoals uitingen van angst of onrust.

Al deze knelpunten dragen ertoe bij dat pijn onderbehandeld kan blijven. De verpleegkundige moet extra tijd nemen om erachter te komen welke zorg de persoon met de verstandelijke beperking nodig heeft. Mensen die de persoon al langer kennen, zoals familie of andere begeleiders, vormen een waardevolle bron van informatie. Zij weten meestal wel hoe een persoon ongenoegen uit en of het gedrag en de stemming zijn veranderd.

Verpleegkundigen kunnen ook pijnbeoordelingsinstrumenten gebruiken als hulpmiddel om pijn te herkennen, zoals in de casus is gebeurd. Zo is er de Checklist Pijngedrag (CPG), een observatieschaal voor het herkennen van pijn bij kinderen met een zeer ernstige verstandelijke handicap die niet in staat zijn om in woorden hun pijn aan anderen duidelijk te maken. Er zijn enkele instrumenten beschikbaar waarmee een volwassene geobserveerd kan worden, maar de waarde daarvan voor mensen met een verstandelijke beperking is wetenschappelijk nog beperkt onderbouwd. De PACSLAC-D is een checklist van 24 fysieke en emotionele pijnuitingen die zorgverleners beter in staat stelt om vast te stellen of mensen met cognitieve beperkingen pijn hebben (zie ook paragraaf 5.1). ${ }^{6}$ De Rotterdam Elderly Pain Observation Scale (REPOS) is een ander observatie-instrument om signalen van pijn te registreren bij mensen met cognitieve beperkingen. ${ }^{\text {? }}$

\subsubsection{Contacten met familie en de wettelijke vertegenwoordiger}

Het is belangrijk om de naaste familie zo veel mogelijk bij de zorg te betrekken. Familieleden kunnen, naast de persoonlijk begeleider, een belangrijke rol spelen in het leven van de cliënt en ze voelen zich vaak sterk betrokken bij de cliënt. Zij kennen doorgaans de cliënt goed waardoor zij een waardevolle informatiebron zijn bij het inschatten van wat de cliënt wil en nodig heeft. De casus van Kim laat zien hoe belangrijk het is om familie te betrekken bij de zorg en beslissingen rond het levenseinde, zoals het staken van de sondevoeding.

Als een cliënt niet in staat is beslissingen te nemen, dan is er een wettelijke vertegenwoordiger; dat is meestal een naast familielid. Als belangenbehartiger van de cliënt neemt de wettelijke vertegenwoordiger een standpunt in over de te maken keuzen. De wettelijke vertegenwoordiger is ook de vertegenwoordiger van 
de familieleden en vrienden en het formele aanspreekpunt namens hen voor de verpleegkundige.

Communiceren met de familie is belangrijk, maar in de praktijk niet altijd vanzelfsprekend. Uit onderzoek naar beslissingen rond het levenseinde, zoals het verhogen van de dosering van pijnmedicatie of het stoppen van levensverlengende behandelingen, bleek dat slechts in de helft van de beslissingen de familie was betrokken. $^{8}$

\subsubsection{Ondersteuning van de medebewoners van de cliënten}

Veel cliënten met een verstandelijke beperking leven in een groep met vijf tot vijftien medebewoners. Voor de groepsgenoten is het veelal ook een ingrijpende periode als één van hen ernstig ziek is en uiteindelijk doodgaat. Zorgverleners moeten daarvoor aandacht hebben door bijvoorbeeld goede voorlichting te geven over wat er gebeurt, de dood en bijvoorbeeld het verschil tussen begrafenis en crematie. Het praten daarover, het samen bezig zijn met de cliënt, en het helpen bij de zorg kunnen heilzaam zijn, waardoor medebewoners rustiger reageren op wat er allemaal gebeurt. Ook hier kan een rouwkoffer soms handvatten voor een gesprek bieden. Een gedragskundige of geestelijk begeleider kan hierbij ondersteuning bieden.

\subsubsection{De rol van de verschillende zorgverleners}

In de verstandelijk gehandicaptenzorg zijn er vaak meerdere soorten zorgverleners bij een cliënt betrokken, zoals een persoonlijk begeleider, een psycholoog/pedagoog, een arts voor verstandelijk gehandicapten. Soms is er ook een geestelijk begeleider, fysiotherapeut of diëtist aan de instelling verbonden. Dat is een voordeel in de zin dat er in de palliatieve fase relatief makkelijk een multidisciplinair team om de cliënt staat. Dit is op te maken uit de casus. Soms ontbreekt echter bij hen de specifieke kennis en ervaring over palliatieve zorg. Daarbij speelt ook mee dat het merendeel van de begeleiders een agogische opleiding heeft en daardoor weinig medische en verpleegkundige kennis heeft. Mede daarom is het belangrijk dat zorgverleners van mensen met een verstandelijke beperking waar nodig een beroep doen op specialistische palliatieve expertise.

In Nederland bestaat een dekkend netwerk van palliatieve consultatieteams vanuit de regionale integrale kankercentra (zie hoofdstukken 1 en 2) die veelal bestaan uit gespecialiseerde verpleegkundigen en artsen. Zij geven zorgverleners advies en ondersteuning op het gebied van palliatieve zorg. In Vlaanderen zijn er ondersteuningsequipes verbonden aan regionale netwerken palliatieve zorg (zie hoofdstukken 1 en 2). In sommige regio's in Nederland is er een afdeling van Vrijwilligers Palliatieve Terminale Zorg (VPTZ) die zich ook richt op mensen met een verstandelijke beperking.

Voor bijvoorbeeld wijkverpleegkundigen en huisartsen die te maken hebben met thuiswonende mensen met een verstandelijke beperking, kan het (daarnaast) zinvol 
zijn om collega-zorgverleners uit een instelling voor verstandelijk gehandicapten te consulteren, bijvoorbeeld over agogische aspecten of over zorgbehoeften die samenhangen met de veelvoorkomende multimorbiditeit bij deze doelgroep.

Bij complexe situaties biedt een zogenoemd moreel beraad mogelijk ondersteuning. Een moreel beraad is een methodische bespreking van de casus, geleid door een gespreksleider (bijvoorbeeld een teamleider of verantwoordelijk arts). In de bespreking, waar alle betrokkenen aan deelnemen, worden de verschillende meningen en mogelijkheden over kwaliteit van leven en wat daarbij goede zorg is uitgebreid geïnventariseerd. Dit helpt de zorgverleners om samen een handelwijze af te spreken.

\subsubsection{Handvatten}

Er komen steeds meer publicaties beschikbaar die zorgverleners een houvast bieden bij hun beleid. De beroepsorganisatie Verpleegkundigen \& Verzorgenden Nederland (V\&VN) heeft een handreiking uitgegeven voor verpleegkundigen en verzorgenden: Hoe zorg je voor ongeneeslijk zieken met een verstandelijke beperking? Hierin wordt beschreven hoe zij de mensen met een verstandelijke beperking en hun omgeving zo goed mogelijk kunnen ondersteunen in de laatste levensfase. ${ }^{9}$ De Vereniging van Integrale Kankercentra heeft een multidisciplinaire richtlijn ontwikkeld over palliatieve zorg voor mensen met een verstandelijke beperking. ${ }^{\circ}$ De Nederlandse Vereniging voor Artsen in de Verstandelijk Gehandicaptenzorg heeft een richtlijn voor beslissingen rondom het levenseinde." Al deze documenten kunnen verpleegkundigen gebruiken om de cliënt in de eigen omgeving te verzorgen en te laten sterven. Als dat niet lukt, dan is het in Nederland op sommige plaatsen mogelijk om gebruik te maken van een voorziening die bedden beschikbaar heeft voor mensen met een verstandelijke beperking die intensieve verpleegkundige zorg nodig hebben. Een enkele instelling voor mensen met een verstandelijke beperking heeft een dergelijke voorziening. ${ }^{12}$ Sommige verpleeghuizen geven ook zorg aan deze doelgroep. Of er dergelijke plekken zijn hangt af van de regio.

\section{Casus}

Kim overlijdt op 37-jarige leeftijd in een instelling voor mensen met een verstandelijke beperking, waar ze sinds haar eerste verjaardag woonde. Kim is geboren met een zeldzame erfelijke aandoening waardoor haar motoriek ernstig verstoord is en ze een beperkte levensverwachting heeft. Kims ontwikkelingsniveau wordt geschat op een half tot 1 jaar. Nabijheid, voorspelbaarheid, vertrouwen en veiligheid zijn belangrijk in de zorg voor haar. Met haar communiceren gaat via stemgeluiden, aanraken, liedjes zingen en masseren. Toen Kim 14 jaar was, kon ze niet meer zelf eten en drinken en kreeg ze een PEG-sonde.

Als Kim 29 jaar is merken de begeleiders dat haar spierspanning omhoog gaat en dat ze minder goed reageert op de medicijnen die ze daarvoor krijgt. Omdat 
Kim niet kan aangeven hoeveel last zij daarvan heeft, besluiten de begeleiders een gesprek te regelen met de arts en de orthopedagoog van de instelling. Zij besluiten twee observatielijsten in te zetten: één om de spier(ont)spanning in kaart te brengen en de Checklist Pijngedrag. Als de persoonlijke begeleider de indruk krijgt dat Kim veel last ondervindt van haar spanning, initieert zij opnieuw een gesprek met de ouders en de arts in de instelling. Daarin wordt besloten om Kim niet meer in het ziekenhuis op te laten nemen en haar zo goed mogelijk op de eigen afdeling te blijven begeleiden. De arts overlegt regelmatig met het ziekenhuis over de doseringen van de morfine en de rustgevende medicatie.

Het multidisciplinaire team, bestaande uit de arts, orthopedagoog, geestelijk verzorger, clustermanager en persoonlijk begeleider, begeleiden Kim samen met de ouders. Zij proberen daarbij in te spelen op wat Kim nog als aangenaam kan ervaren, zoals in bad gaan met lekkere olie en haar favoriete liedjes. De ouders zijn elk tijdstip van de dag welkom. De geestelijk begeleider van de instelling bezoekt in de laatste twee maanden enkele keren de ouders om met hen te praten over het naderend overlijden en over hun wensen voor de zorg voor en na het overlijden.

Anderhalve dag voordat Kim overlijdt is er een gesprek met het multidisciplinaire team en de ouders waarin zij het verdere beleid bespreken. Besloten wordt geen levensverlengende behandelingen meer te doen en de voeding via de PEGsonde te staken; voor de begeleiders en de ouders een erg moeilijke stap, te meer omdat Kim er door de sondevoeding 'gezond' uitziet. Na het stoppen van de voeding, overlijdt Kim rustig na anderhalve dag. De ouders hebben Kim gewassen, kleding uitgezocht en aangetrokken en verder alles in de geest van Kim kunnen regelen.

In de periode daarna is er voor het team een zingevingsbijeenkomst. Sommige teamleden hebben behoefte aan een individueel gesprek. Na drie maanden worden de ouders uitgenodigd voor een gesprek met de direct betrokkenen rondom Kim. De ouders hebben vooral de openheid om over en weer vragen te stellen gewaardeerd.

\subsubsection{Conclusie}

Palliatieve zorg voor mensen met een verstandelijke beperking vraagt specifieke deskundigheid van de zorgverleners die vaak onvoldoende aanwezig is. Elke patiënt is weer anders, dus telkens opnieuw moet gekeken worden welke zorg het beste is. Verpleegkundigen in instellingen voor mensen met een verstandelijke beperking kunnen deskundigen buiten de instelling consulteren. Verpleegkundigen werkzaam buiten de verstandelijk gehandicaptenzorg kunnen deskundigen binnen de gehandicaptenzorg consulteren. De verpleegkundige kan daarvoor contact opnemen met een arts in een instelling voor mensen met een verstandelijke beperking. De laatste 
jaren zijn er ook documenten en hulpmiddelen ontwikkeld die verpleegkundigen ondersteunen bij het geven van palliatieve zorg aan mensen met een verstandelijke beperking. ${ }^{13}$

\section{LITERATUUR}

1 Speet, M., A.L. Francke, A. Courtens \& L.M.G. Curfs. Zorg rondom het levenseinde van mensen met een verstandelijke beperking. Een inventariserend onderzoek. NIVEL, Utrecht, 2006.

2 Veer, A.J.E. de, A.L. Francke, M. Speet \& E.P. Poortvliet. Verpleegkundige zorg rondom het overlijden van mensen met een verstandelijke beperking. Nederlands Tijdschrift voor de Zorg aan mensen met een verstandelijke beperking, 2004, 2, 110-129.

3 Evenhuis, H.M. Want ik wil nog lang leven. Moderne gezondheidszorg voor mensen met verstandelijke beperkingen. RVZ, Zoetermeer, 2002.

4 Meeusen-van de Kerkhof, R., H. van Bommel, W. van de Wouw \& M. Maaskant. Kun je uit de hemel vallen? Beleving van de dood en rouwverwerking door mensen met een verstandelijke handicap. LKNG, Utrecht, 2001.

5 De rouw- of troostkoffer is in Nederland verkrijgbaar bij de 's Heeren Loo Midden-Nederland $(055-369615$ ) ; in Vlaanderen verkrijgbaar via Het Grote Plein. www.hetgroteplein.be.

6 Zwakhalen, S.M.G. Het beoordelen van pijn bij ernstig dementerende verpleeghuisbewoners. Verpleegkunde, 2008, 4, 21-23.

7 Herk, R. van. A closer look at pain in nursing home residents. Proefschrift. Erasmus Universiteit, Rotterdam, 2008.

8 Wagemans, A., H. van Schrojenstein Lantman-de Valk, I. Tuffrey-Wijne, et al. End-of-life decisions: an important theme in the care for people with intellectual disabilities. Journal of Intellectual Disability Research, 2010, 54, 516-524.

9 Hoe zorg je voor ongeneeslijk zieken met een verstandelijke beperking? V\&VN, Utrecht. www.venvn.nl.

10 Haan, K. de \& N. van Rossum. Richtlijn Palliatieve zorg voor mensen met een verstandelijke beperking. 2010. www.pallialine.nl.

11 Medische beslissingen rond het levenseinde bij mensen met een verstandelijke beperking. Een standaard. NVAVG, 2007.

12 Bijvoorbeeld Palatijn in Sint-Oedenrode, een voorziening voor intensieve zorg dat onderdeel is van Dichterbij.

13 Een overzicht van de beschikbare materialen en hulpmiddelen is te vinden op de website van Agora. www.palliatief.nl. 


\subsection{PALLIATIEVE ZORG IN DE PSYCHIATRIE}

\section{Guy Hannes en llse Decorte}

In onze westerse maatschappij is een duidelijke toename merkbaar van psychische ziek(t)en. Tegelijk stellen we vast dat er in diezelfde maatschappij een groot taboe op dit onderwerp blijft rusten en als het al besproken wordt, veel mensen of onwetend zijn of tal van vooroordelen hebben. De hoge eisen om 'mee te kunnen doen' en de steeds afnemende tolerantie voor 'vreemd' gedrag maken het voor de psychiatrische patiënt (en de psychiatrische sector) niet gemakkelijk.

Een groot aantal psychiatrische aandoeningen is niet te genezen en de mensen die aan deze aandoeningen lijden, overlijden dan ook vaak binnen een instelling in de psychiatrie. Ook in deze sector brengt een hogere levensverwachting een veranderende kijk op leven en dood met zich mee en krijgt het begrip kwaliteit van leven een meer centrale plaats. In deze paragraaf wordt stilgestaan bij enkele aspecten van zorg rond het levenseinde van chronisch psychiatrische patiënten.

\subsubsection{Enkele cijfers en ontwikkelingen}

Over hoe vaak palliatieve zorg in de psychiatrie in Nederland en België voorkomt, zijn momenteel geen precieze cijfers beschikbaar. In de quick scan van het Trimbos-instituut wordt melding gemaakt van 425 mensen die in Nederland in 2007 op een natuurlijke wijze overleden in psychiatrische instellingen. ${ }^{1}$ Op basis van de MPG (minimale psychiatrische gegevens) van de federale overheid in België was er in 2006 sprake van 294 mensen met een verwachte natuurlijke dood in psychiatrische voorzieningen (221 voor Vlaanderen, 66 voor Wallonië en 7 voor Brussel). Deze cijfergegevens kunnen indicatief zijn voor het potentieel aan benodigde palliatieve zorg in deze sector.

In de psychiatrische zorgverlening krijgt palliatieve zorg in Vlaanderen en Nederland langzaam een duidelijker plaats. Opvallend hierin zijn twee benaderingswijzen waarin de palliatieve zorg en de psychiatrie elkaar ontmoeten. Enerzijds is er de aandacht van palliatieve zorg bij de (chronisch) psychiatrische patiënt met een fysiek lijden (lichamelijk, terminaal ziekteproces), wat eigen accenten vraagt en zowel voor de psychiatrische als palliatieve zorgverlener de nodige knelpunten met zich meebrengt. Anderzijds is er de vraag wat het palliatief zorgconcept kan bieden bij de uitbehandelde psychiatrische patiënt, bij wie geen lichamelijke ziekte aanwezig is. Kunnen de principes van palliatieve zorg toegepast worden bij een bredere groep dan alleen (somatisch) terminale psychiatrische patiënten? ${ }^{2}$

Beide invalshoeken zijn mooie uitdagingen om samen te zoeken naar mogelijkheden en beperkingen. 'Psychiatrische palliatie' of 'palliatieve psychiatrie': alleen het woordgebruik stemt al tot nadenken ... 


\subsubsection{De context van de (chronisch) psychiatrische patiënt}

Palliatieve zorg is de interdisciplinaire totaalzorg voor mensen die ongeneeslijk ziek zijn en een beperkte levensverwachting hebben (zie ook paragraaf 1.1). De aanpak spitst zich toe op de kwaliteit van het resterende leven, en de wensen en waarden van de patiënt zijn het uitgangspunt. Voor de vertaling naar de psychiatrische patiënt is het niet onbelangrijk even stil te staan bij de specifieke context van de (chronisch) psychiatrische patiënt.

Zonder te willen uitgaan van dé psychiatrische patiënt en hem/haar in een keurslijf te stoppen, kunnen we niet voorbij aan een aantal fundamentele problemen van mensen met (langdurige) psychische problemen. Veel van deze mensen verblijven wel in de samenleving, maar maken er nauwelijks deel van uit. Anderen dikwijls mensen met hardnekkige psychiatrische ziektebeelden met irreversibele symptomen en vaak medicamenteuze resistentie - verblijven lang in instellingen. Ze krijgen daar de nodige ondersteuning zonder dat ze intensieve therapeutische zorg nodig hebben.

Daarbij zijn er vaak beperkingen en problemen zoals:

in sociale isolatie: wonen en leven in de instelling of alleenwonend (zonder vaste partner);

wi band met familie minimaal of afwezig (wegens een belaste familiale geschiedenis);

- beperkte contactvaardigheden/mondigheid;

- problematiek van wils- en/of handelingsbekwaamheid;

= geen of beperkte structurele dagbesteding;

in eigen belevingswereld;

= beperkte psychische draagkracht en aanpassingsvermogen.

\section{Casus}

Gust, 72 jaar oud, lijdt aan paranoïde schizofrenie en verblijft in een psychiatrische instelling. Hij is vaak agressief en heeft regelmatig hallucinaties, waarvoor hij soms geïsoleerd wordt. Hij wil ook steeds weg van de afdeling - naar zijn broer. Ten gevolge van zijn COPD was hij recent tweemaal opgenomen in het ziekenhuis met een longontsteking. Hij heeft daarnaast ernstige nier- en hartproblemen. In het ziekenhuis was Gust zeer angstig en hij komt er ook psychotisch van terug: na de opname is zijn longontsteking genezen maar lichamelijk en psychisch gaat hij achteruit.

$\mathrm{Na}$ overleg van het team met de familie wordt afgesproken om Gust in de toekomst niet meer op te nemen in het ziekenhuis. Met Gust zelf is hierover geen overleg, omdat hij dat in die periode emotioneel niet aankan.

Er wordt geopteerd voor een palliatieve benadering: de medicatie wordt afgebouwd met uitzondering van pijnmedicatie en antipsychotica. 
Gust roept de hele tijd. Lichamelijk contact maakt hem steeds overstuur. Er wordt een bezoek aan zijn broer gepland, maar ook hierover is hij erg onrustig: hij weigert de afdeling te verlaten.

De palliatieve benadering van Gust confronteert ons met een reeks specifieke problemen, eigen aan de sector. Zonder te willen generaliseren willen we in de volgende paragrafen een aantal aandachtspunten tegen het licht houden.

\subsubsection{Pijn- en symptoomcontrole}

'Pijn is wat de patiënt zegt dat het is', is een vuistregel binnen de pijnbehandeling. Bij psychiatrische patiënten is het echter vaak moeilijker dan bij andere patiënten om te duiden wat iemand zegt of laat zien. Niet zelden is er sprake van een andere pijnbeleving (hogere pijndrempel?), en ook de uitingsvormen van pijn zijn zeer divers en beperkt. Verschillende gedragsveranderingen (onrust, agressie, verdriet) kunnen mogelijk wijzen op pijn. Anderzijds wijzen deze gedragsveranderingen niet noodzakelijk op pijn, maar kunnen dit ook symptomen zijn van andere - al dan niet somatische - problemen zoals delier en angst.

Het opstarten van een correcte behandeling en het inschatten van het effect van de mogelijk toegediende medicatie zijn daardoor moeilijk, zowel in de aanpak van pijn als van andere symptomen. Goede observatie en voldoende overleg tussen de verschillende betrokkenen (patiënt, familie en team) zijn onontbeerlijk in de pijn- en symptoomcontrole bij psychiatrische patiënten.

\subsubsection{Psychisch-emotionele ondersteuning}

Palliatieve zorg vertrekt vanuit de wensen van de patiënt en lichamelijk en psychisch comfort staan centraal. Zoals al aangegeven zijn beperkte communicatieve en contactvaardigheden naast een andere belevingswereld factoren die het voor de hulpverlener niet makkelijker maken. Verder zijn beperkte psychische draagkracht en aanpassingsvermogen aandachtspunten die zeker niet uit het oog mogen worden verloren. Wat zijn de aanwezige gevoelens bij de psychiatrische patiënt? In welke mate is er ziekte-inzicht? Welke mogelijkheden en beperkingen zijn er met betrekking tot de waarheidsmededeling? Kan de patiënt dit al dan niet hanteren? In hoeverre kan hij/zij worden betrokken bij het nemen van een (behandel)beslissing? Wat betekent comfort voor de psychiatrische patiënt?

Dit is een reeks vragen die aangeven hoe moeilijk een en ander te vertalen is vanuit de palliatieve zorg. En toch heeft ook de psychiatrische patiënt recht op de nodige psychische ondersteuning en aandacht voor comfort op het einde van zijn/haar leven. Dit doet een beroep op de zorgverlener om mogelijkheden te zoeken en af te tasten. Niet alleen verbale ondersteuning, maar daarenboven op zoek gaan naar non-verbale aanvullende mogelijkheden, zoals relaxatie, massage en muziek, kunnen belangrijk zijn (zie ook paragraaf 4.5 ). 


\subsubsection{Aandacht voor familie}

Specifieke aandacht voor de familie is in de laatste levensfase van de patiënt zeer belangrijk. Veelal stellen we vast dat, als gevolg van een belaste familiale geschiedenis, de band met de familie vertroebeld tot zelfs afwezig is. Toch lijkt het belangrijk om hier ook te verwijzen naar het mogelijk anticiperend rouwen van familieleden. Ze worden in deze laatste fase geconfronteerd met een dubbel taboe: het taboe rond de psychiatrische ziekte enerzijds en het taboe rond sterven anderzijds.

Zeer dikwijls geeft deze laatste levensfase nog een aantal kansen om ook het lijden van de familie (de omgeving) te verlichten door hen te betrekken in de zorg. In welke mate familie nog kan worden betrokken bij de zorg - en hoe groot de eventuele inspraak is in beslissingen die genomen moeten worden, zijn vragen die permanent moeten worden meegenomen in de palliatieve zorg voor de psychiatrische patiënt. Voldoende informeren over de situatie is de basis in de opvang voor familie.

\subsubsection{Spirituele ondersteuning}

Wat betekent kwaliteit van leven voor de psychiatrische patiënt? Welke mogelijke rituelen kunnen hier een belangrijke betekenis hebben? Wat is 'zinvol' om te doen of te laten voor deze patiënt? Wat betekent menswaardigheid en hoe kunnen we de psychiatrisch zieke in zijn menselijke waarde laten? Het is dikwijls erg moeilijk om bij de psychiatrische patiënt zelf te achterhalen hoe hij/zij tegen dergelijke vragen en de antwoorden daarop - aankijkt. Tegelijk stellen we vast dat dergelijke thema's ook de zorgverleners confronteren met zichzelf en hoe zij in het leven staan.

Palliatieve zorg kan hier een meerwaarde betekenen. Ruimte maken om ook met deze aspecten rond het ziek-zijn aan de slag te gaan, is eigen aan palliatieve zorg. Voor de (chronisch) psychiatrische patiënt voor wie vragen over de zin van lijden en ziekte in zijn/haar leven regelmatig de kop opsteken, kan het opmaken van een levensbalans rust brengen. Het opmaken van een levensbalans is een mogelijkheid om met spiritualiteit bezig te zijn: de verpleegkundige (of andere direct betrokken zorgverlener) kan samen met de patiënt tijd nemen en ruimte maken voor vragen die bij de patiënt in de laatste levensfase naar boven komen. Het gaat over vragen als:

" Wat heb ik met mijn leven gedaan?

= Wat wil ik nog doen met het leven dat nog komt (hoe kort ook)?

in Was het zinvol wat ik deed?

- Heb ik eruit gehaald wat erin zat?

- Wat kan ik nog rechtzetten?

- Waarin ben ik mislukt?

Aandacht geven aan dit soort vragen geeft de kans om te komen tot de diepere wortels van het bestaan - van leven en sterven. 


\subsubsection{Palliatieve zorg bij psychiatrische - miet lichamelijk zieke - patiënten}

Ondanks de hoge vlucht van de medische wetenschap over onder meer het functioneren van de hersenen, is een aantal psychiatrische aandoeningen niet te genezen. Palliatieve zorg biedt ondersteuning aan de patiënten en hun omgeving op het ogenblik dat curatieve therapieën niet meer mogelijk zijn. Focus op kwaliteit van leven voor de patiënt en zijn omgeving is essentieel; in de strikte zin van het woord zou men kunnen zeggen dat palliatieve zorg beoogt het lijden te verzachten en streeft naar welbevinden. Dit palliatieve zorgconcept biedt handvatten en uitdagingen in de zorg voor deze patiënten en hun omgeving. ${ }^{3-5}$ Wij zullen hierna enkele uitdagingen noemen.

\section{Met betrekking tot de patiënt}

Het is belangrijk om meer zicht te krijgen op het lijden van de chronisch psychiatrische patiënt. Dit impliceert aanwezigheid en erkenning bieden aan mensen die vaak als onbereikbaar of niet veranderbaar worden beschouwd en die geen aansluiting vinden bij de samenleving of bij zichzelf. Dit betekent dat we moeten proberen om emoties als pijn, angst, (wan)hoop, onmacht en troost te omschrijven en zicht te krijgen op de betekenis ervan bij een individuele patiënt.

\section{Met betrekking tot de familie}

Ook bij familieleden van de chronisch psychiatrische patiënt is er zeer dikwijls een aanhoudend, chronisch en soms uitzichtloos lijden. Voor hen gaat het vaak om telkens opnieuw op een of andere manier te moeten rouwen - los van het sterven. Het is altijd opnieuw loslaten en de draad opnieuw opnemen. Hen in dit permanent balanceren de nodige erkenning en ondersteuning bieden, met oog voor de aanwezige onmacht en frustratie, kan de emotionele last draaglijker maken.

\section{Met betrekking tot de zorguerleners}

Bij zorgverleners zou het palliatief concept een aanzet kunnen zijn tot een mentaliteitsverandering; van cure naar care: loslaten van de behandelingsgedachte ten voordele van de zorggedachte. Ook van zorgverleners die werken met chronisch psychiatrische patiënten wordt op emotioneel vlak erg veel gevraagd. 'Zorg voor de zorgende' is essentieel in palliatieve zorg. Het leren omgaan met onmacht, frustratie, verlies en rouw is fundamenteel in het welbevinden van de hulpverlener.

\subsubsection{Conclusie}

Palliatieve zorg binnen de psychiatrie heeft zeker een meerwaarde. Een belangrijk struikelblok is echter dat de organisaties die met palliatieve zorg bezig zijn, vaak niet vertrouwd zijn met de psychiatrie en dikwijls nog heel wat vooroordelen hebben over mensen met een psychiatrische aandoening. Binnen de psychiatrie is er onvoldoende zicht op de betekenis en mogelijkheden van palliatieve zorg; nog al te vaak wordt 
palliatieve zorg enkel en alleen in verband gebracht met sterven. Toch stellen we vast dat binnen beide sectoren voorzichtige stapjes naar toenadering worden gezet.

Het implementeren en verder uitbouwen van de palliatieve zorgcultuur in psychiatrische voorzieningen is een grote uitdaging. Opbouw van expertise over palliatieve zorg is in de psychiatrie een must. Anderzijds dienen deskundigen in palliatieve zorg ook meer kennis van zaken op te doen over de specifieke zorgbehoeften van de (chronisch) psychiatrische patiënt en zijn omgeving.

\section{LITERATUUR}

1 Verbeek, M., M. Depla \& A.M. Pot, Palliatieve terminale zorg in de geestelijke gezondheidszorg, Quick scan. Trimbos-instituut, Utrecht, 2009.

2 Holman, B.J. \& D.H. Brendel. The ethics of palliative care in psychiatry. The Journal of Clinical Ethics, $2006,17,333-338$.

3 Haekens, A. Mist psychiatrie palliatieve boot niet? Tertio, 2007, 407, 3-5.

4 Haekens, A. \& J. Hermans (red.). Geen eind aan mijn pijn. Over uitzichtloos lijden. Garant, Apeidoorn, 2008.

5 Tuerlings, J.H.A.M., M.E.T.M. Müller, B. Verwey \& J.A. van Waarde. Palliatieve zorg op een psychiatrisch-medische unit. Nederlands Tijdschrift voor Geneeskunde, 2008, 152, 1949-1952. 


\section{Bijlage Websites over palliatieve zorg}

Zowel nationaal als internationaal is op websites veel informatie te vinden over diverse aspecten van de palliatieve zorg. Hieronder staat een lijst van Nederlandse, Vlaamse en internationale websites met veel informatie over diverse aspecten van de palliatieve zorg.

\section{DE NEDERLANDSE PALLIATIEVE ZORG}

\section{Het aanbod aan palliatieve zorg}

http://netwerk-palliatieve-zorg.leukgevonden.nl/

netwerk-palliatieve-zorg-paginaz.html

http://netwerk-palliatieve-zorg.verzamelgids.nl

http://oud.palliatief.nl/nationaal/index.htm?mid=26

http://palliatief.startpagina.nl

http://palliatief.verzamelgids.nl

http://palliatieveverpleegkunde.venvn.nl

http://palliatievezorg.boogolinks.nl

http://palliatievezorg.eigenstart.nl

http://palliatievezorg.startkabel.nl

http://palliatieve-zorg.uwstart.nl

http://palliatievezorg.verzamelgids.nl

http://sterven.startpagina.nl

www.christelijkehospices.nl

www.hospices-highcare.nl

www.ikcnet.nl/sociale_kaart

www.kiesbeter.nl

www.kinderhospice.nl

www.laatstelevensfase.nl 
www.mijnzorg.nl

www.netwerkpalliatievezorg.nl (zie hieronder de sites van de vele netwerken)

www.npvzorg.nl

www.palliatief.nl

www.palliatiefconsult.nl

www.palliatievezorg.nl

www.palliatievezorggelderland.nl/index.php?recID $=3$

www.vptz.nl

Organisatie van palliatieve zorg

www.ikcnet.nl

www.kitzz.nl

www.minwws.nl

www.nivel.nl

www.nptn.nl

www.palliactief.nl

www.palliatief.nl

www.vikc.nl

Onderzoek in de palliatieve zorg

http://documentatiecentrum.palliatief.nl

www.ikcnet.nl

www.nivel.nl

www.zonmw.nl/nl/programmas/palliatieve-zorg.html

Projecten in de palliatieve zorg

http://documentatiecentrum.palliatief.nl

http://projectenbank.palliatief.nl

Aanbod aan consultatievoorzieningen in de palliatieve zorg

www.ikcnet.nl

www.npvzorg.nl

www.palliatief.nl

Onderwijs in de palliatieve zorg

www.ikcnet.nl/scholingsaanbod

www.leerhuizenpalliatievezorg.nl

\section{Richtlijnen palliatieve zorg}

www.oncoline.nl/index.php?pagina=/richtlijn/item/pagina.php\&richtlijn_id=465

www.pallialine.nl 
Het aanbod aan palliatieve zorg www.delaatstereis.be

www.leif.be

www.palliatief.be

www.palliatieve-zorg-en-kinderen.be

Organisatie van palliatieve zorg

www.leif.be

www.palliatief.be

Onderzoek in de palliatieve zorg www.cancer.be

www.endoflifecare.be

www.onderzoeksforumpalliatievezorg.eu

www.pallialine.be

www.palliatief.be

Projecten in de palliatieve zorg

www.cancer.be

www.delaatstereis.be

www.endoflifecare.be

www.pallialine.be

www.palliatief.be

www.vlk.be

Aanbod aan consultatievoorzieningen in de palliatieve zorg www.gezondheid.be

www.leif.be

www.vlk.be

Onderwijs in de palliatieve zorg

www.cancer.be

www.leif.be

www.palliatief.be

www.vlk.be

Richtlijnen palliatieve zorg

www.delaatstereis.be

www.endoflifecare.be 
www.pallialine.be

www.palliatief.be

\section{INTERNATIONALE WEBSITES}

Association of Children's Hospices: www.childhospice.org.uk EAPC: www.eapc.com

European Cancer Centre: www.eurcancen.org

European Organisation for Research and Treatment of Cancer: www.eortc. be Growthhouse: www.growthhouse.org

Help the Hospices: www.hospiceinformation.info

Hospice Foundation of America: www.hospicefoundation.org

National Cancer Institute: www.cancer.gov

National Hospice Organisation, Verenigde Staten: www.nho.org

Oncolink: oncolink.upenn.edu

Organisation of European Cancer Institutes: www.uicc.org

Pallmed: www.pallmed.com

Promoting Excellence in End-of-Life Care: www.promotingexcellence.org

www.eolc-observatory.net

www.europall.eu

www.kcl.ac.uk/schools/medicine/depts/palliative/arp/prisma

www.mailbase.org.uk/lists/palliative-medicine

www.nationalconsensusproject.org

www.opcareg.eu

www.palliativedrugs.com

www.who.int/cancer/palliative 


\section{Redactie en auteurs}

\section{Redactie}

Johan Bilsen is diensthoofd van de vakgroep Maatschappelijke Gezondheidszorg van de Vrije Universiteit Brussel. Hij is docent binnen diverse opleidingsprogramma's en senior onderzoeker bij de VUB-UGent-onderzoeksgroep Zorg rond het Levenseinde. Hij is opgeleid als gegradueerde verpleegkundige, heeft een master medischsociale wetenschappen en is doctor in de sociale gezondheidswetenschappen, en was geruime tijd werkzaam in de gezondheidszorg in Vlaanderen.

Anneke L. Francke is hoogleraar verpleging en verzorging in de laatste levensfase aan de Vrije Universiteit in Amsterdam. Tevens is zij coördinator van het onderzoeksprogramma Verpleging en Verzorging van het NIVEL te Utrecht. Zij is opgeleid als verpleegkundige $A$ en sociologe. Haar academische proefschrift (1996, Universiteit Maastricht) ging over pijnbestrijding door verpleegkundigen bij chirurgisch-oncologische patiënten.

Adriaan Ph. Visser, psycholoog, werkte jaren bij het Helen Dowling Instituut, centrum voor psycho-oncologie te Utrecht. Hij is thans assistant lector aan de Hogeschool te Rotterdam op het terrein van transities in zorg. Hij publiceerde over communicatie in de gezondheidszorg, palliatieve zorg en complementaire zorg, en is redacteur van Patient Education and Counseling.

\section{Auteurs}

Sabien Bauwens is klinisch psychologe en psychotherapeute. Ze is werkzaam binnen de dienst Supportieve en Palliatieve Zorg in het Oncologisch Centrum van het Universitair Ziekenhuis Brussel. Ze is medeoprichter, trainer en bestuurslid van het Cédric Hèle instituut (Instituut voor Psychosociale Oncologie) te Mechelen en bestuurslid van LEIF (Levenseinde Informatieforum). 
Karen van Beek is radiotherapeut-oncoloog. Ze is verbonden aan de dienst Radiotherapie en het palliatief supportteam van het Universitair Ziekenhuis te Leuven en doet onderzoek in het kader van het Europese project Best Practices in Palliative Care.

Marinus van den Bergis als geestelijk verzorger werkzaam voor Antonius-IJsselmonde, centrum voor revalidatie en ziekenhuisverplaatste zorg, en het regionaal palliatief centrum Cadenza te Rotterdam. Hij publiceerde onder meer Voor bij het einde en Rouwen in de tijd, en verzorgt lezingen en cursussen over sterven, ziek-zijn en rouwen.

Inge Bossuyt is verpleegkundige en licentiaat medisch-sociale wetenschappen. Ze is werkzaam als verpleegkundig coördinator en verpleegkundig specialist in het palliatief supportteam in het Universitair Ziekenhuis Leuven.

Rob Bruntink is freelance journalist/auteur met palliatieve zorg als specialisatie. Hij is hoofdredacteur van Pallium en schreef onder meer De laatste slaap (over palliatieve sedatie/euthanasie), In het teken van leven (over ongeneeslijk zieke kinderen) en Een goede plek om te sterven (over palliatieve zorg).

Ilse Decorte is afgestudeerd aan de KU Leuven als arts en momenteel werkzaam als huisarts in het Openbaar Psychiatrisch Ziekenhuis (OPZ) in Geel in de gezinsverpleging en in de gerontopsychiatrie waar zij ook verantwoordelijk is voor de palliatieve zorg. Daarnaast is zij ook als equipearts bij de thuiszorgequipe Ispahan verantwoordelijk voor de palliatieve thuiszorg.

Paul Destrooper begeleidt personen bij hun vragen over het levenseinde. Hij is als vormingsverantwoordelijke verbonden aan het Forum Palliatieve Zorg en aan LEIF (Levenseinde Informatieforum). Hij onderzoekt de mogelijkheden om te komen tot een attitude die een professional of een patiënt de mogelijkheid biedt een eigen leerof levenstraject op te zetten.

Wim Distelmans is kankerspecialist in het Universitair Ziekenhuis Brussel en geeft les in palliatieve geneeskunde aan de Vrije Universiteit Brussel. Hij is voorzitter van het Forum Palliatieve Zorg, de palliatieve thuiszorg Omega en het Levenseinde Informatieforum (LEIF). Hij is ook voorzitter van de Belgische Federale Commissie Euthanasie.

Aart M. Eliens is verpleegkundige A en B en verplegingswetenschapper. Hij is werkzaam als docent specialist bij de opleiding Master Advanced Nursing Practice van Hogeschool Inholland te Amsterdam. 
Bart Van den Eynden is huisarts en diensthoofd van het Centrum Palliatieve Zorg GZA te Antwerpen. Daarnaast is hij hoogleraar palliatieve geneeskunde aan de Universiteit Antwerpen en coördinator van de interuniversitaire postgraduaat cursus Palliatieve Zorg voor Artsen. Hij publiceerde veel artikelen over palliatieve en chronische zorg.

Fuusje M. de Graaff is sociaal geografe en agoge. Ze werkt als trainer en projectleider in MUTANT, een bureau dat het interculturele werken bevordert in de gezondheidszorg, het onderwijs en de kinderopvang. Daarnaast werkt ze aan de Universiteit van Amsterdam aan haar promotieonderzoek over de palliatieve zorgverlening aan patiënten van Turkse en Marokkaanse herkomst.

Alexander de Graeff is werkzaam als internist-oncoloog bij het Universitair Medisch Centrum Utrecht. Daarnaast werkt hij als hospicearts bij het Academisch Hospice Demeter in De Bilt. Hij is tevens eindredacteur van de richtlijnen palliatieve zorg van de Vereniging van Integrale Kankercentra.

Guy Hannes is gegradueerd ziekenhuis- en psychiatrisch verpleegkundige. Hij volgde de opleiding gestaltpsychotherapie en postgraduaat ethiek. Gedurende tien jaar is hij werkzaam geweest op de afdeling Spoedhospitalisatie Psychiatrie (crisisinterventiecentrum) van het Universitair Ziekenhuis te Leuven. Sinds vijf jaar is hij diensthoofd in een woon- en zorgcentrum te Geel en sinds 2000 coördinator van het palliatief netwerk arrondissement Turnhout.

Frie Hermans is logopediste en gerontologe. Ze werkte als stafmedewerker algemeen beleid voor de Federatie Palliatieve Zorg Vlaanderen.

Trudie van Iersel studeerde aan de Universiteit van Amsterdam en specialiseerde zich vervolgens in de palliatieve zorg in Vlaanderen. Hier was zij tien jaar actief in Brugge e.o. als netwerkcoördinator, de afgelopen twee jaar was zij verbonden aan de Federatie Palliatieve Zorg Vlaanderen als researchcoördinator.

Bie Lambrechts is gegradueerd verpleegkundige en licentiaat in de medico-sociale wetenschap en het ziekenhuisbeleid. Ze was verpleegkundige bij verschillende ziekenhuisdiensten waaronder pediatrie, spoedgevallenzorg en gynaecologie. Daarnaast twintig jaar staf- en beleidsmedewerker binnen de beroepsorganisatie voor verpleegkundigen en vroedvrouwen. Daarna zelfstandig consulent gespecialiseerd in vormingsinitiatieven en coördinatie van diensten, waaronder voornamelijk de palliatieve sector. 
Katrien Luijkx promoveerde in 2001 op sociaal-wetenschappelijk onderzoek naar zorg voor ouderen. Zij is als senior onderzoeker en onderzoekscoördinator verbonden aan de Academische Werkplaats Chronische Zorg van Tranzo, Universiteit van Tilburg. Als copromotor/begeleider is zij bij diverse onderzoeken op het brede terrein van ouderen betrokken.

Katrien Moens is ziekenhuisverpleegkundige en verplegingswetenschapper. Zij is werkzaam als lector binnen de bacheloropleiding verpleegkunde aan de HogeschoolUniversiteit Brussel.

Thirza E. Olden is verpleegkundige en verplegingswetenschapper. Ze is werkzaam als adviseur palliatieve zorg bij het Integraal Kankercentrum Zuid te Eindhoven en voorzitter van V\&VN Palliatieve Verpleegkunde te Utrecht.

Gert Olthuis is postdoc onderzoeker bij de vakgroep Zorgethiek van de Universiteit van Tilburg (www.zorgethiek.nu) en programmaleider Menslievende Zorg bij het St. Elisabeth Ziekenhuis in dezelfde stad (www.liefziekenhuis.nl).

Marja Oud is verpleegkundige B en $\mathrm{Z}$. Zij is werkzaam als senior cliëntbegeleidster bij Esdégé-Reigersdaal met als specialisme dementie bij cliënten met downsyndroom en complexe problematiek. Sinds eind 2010 is zij landelijk voorzitter van de V\&VN Verstandelijk Gehandicaptenzorg.

Marleen Renard is als kinderarts afgestudeerd aan de Katholieke Universiteit Leuven, gespecialiseerd in de hemato-oncologie bij kinderen en met een bijzondere interesse voor palliatieve zorg bij kinderen. In het begin van de jaren negentig is een specifieke dienst opgericht om deze patiëntengroep te begeleiden in deze moeilijke fase. Zij is als arts verbonden aan dit team. In de loop van de jaren is de opgebouwde expertise aangeboden aan alle kinderen met levensbedreigende en levensverkortende aandoeningen.

Ilse Ruysseveldt is maatschappelijk assistente. 'Zij is werkzaam binnen het kinderziekenhuis van het Universitair Ziekenhuis Leuven als coördinator van de transmurale liaisonequipe KITES (kinderen in thuis- en supportieve zorg). Zij is bestuurslid van de Federatie Palliatieve Zorg Vlaanderen en maakt deel uit van de Paediatric Palliative Care Group van EAPC.

Jos M.G.A. Schols is specialist ouderengeneeskunde en hoogleraar in het specialisme ouderengeneeskunde aan de Universiteit Maastricht. Zijn thuisbasis in Maastricht is bij de vakgroep Huisartsgeneeskunde en de School for Public Health and Primary Care, Caphri. Hij is tevens manager van de Dienst Behandeling \& Begeleiding van Vivre, een grote zorgorganisatie in Maastricht en het Heuvelland. 
Jenny T. van der Steen is epidemioloog en onderzoeker naar levenseindezorg voor mensen met dementie. Zij is verbonden aan de afdelingen Verpleeghuisgeneeskunde en Sociale Geneeskunde van het EMGO Instituut voor onderzoek naar gezondheid en zorg van het VU medisch centrum te Amsterdam.

Saskia Teunissen is oncologieverpleegkundige en gezondheidswetenschapper. Zij is als universitair hoofddocent verbonden aan de afdeling Medische Oncologie van het Universitair Medisch Centrum Utrecht en werkzaam als hoofd van het Kenniscentrum Palliatieve Zorg Utrecht. Daarnaast is zij directeur van Academisch Hospice Demeter in De Bilt.

Marij Thewissen is GZ-psycholoog, zij heeft de postmasteropleiding psychosociale oncologie gedaan. Zij werkt met oncologiepatiënten, zowel in de acute als in de terminale fase van hun ziekte, en heeft daarnaast als speciaal aandachtsveld de nazorg aan nabestaanden in haar pakket bij Laurens Rotterdam, Regio Zuid-Oost.

Madeleen J. Uitdehaag is verpleegkundige A en verplegingswetenschapper. Zij is werkzaam als projectmedewerker richtlijnen palliatieve zorg bij de Vereniging Integrale Kankercentra (VIKC) te Utrecht en als verpleegkundig onderzoeker bij het kenniscentrum palliatieve zorg (UPC) te Utrecht.

Annick Vanderoost was voorheen werkzaam in een RVT voor lichamelijk gehandicapten. Thans is zij als palliatief verpleegkundige werkzaam in het Centrum voor Palliatieve Zorg GZA te Antwerpen. Zij is heel erg begaan met de kwaliteit van palliatieve zorg op de werkvloer en volgt thans een bachelor palliatieve zorg (banaba).

Monique C.V.M. Vahedi Nikbakht-van de Sande is hbo-verpleegkundige en algemeen sociaal wetenschapper. Zij is werkzaam als docent bij de opleiding Master Advanced Nursing Practice en als onderzoeker bij het Instituut voor Gezondheidszorg, kenniscentrum Transities in Zorg van de Hogeschool Rotterdam, waar zij promotieonderzoek verricht naar transities in de palliatieve fase.

Anke de Veer is psycholoog en werkt als senior onderzoeker bij het NIVEL, het Nederlands instituut voor onderzoek van de gezondheidszorg. Zij doet daar onderzoek naar het werken in de verpleging en verzorging.

Pascalle Voerman is verpleegkundig specialist palliatieve zorg met als speciaal aandachtsveld transities en zorg voor zorgenden bij Laurens Rotterdam, Regio Zuid-Oost. Zij is verpleegkundig consulent bij het consultatief palliatief team in Rotterdam. Daarnaast is zij als docent verbonden aan de Leerhuizen Palliatieve Zorg. 
Bert H.J.M. Vrijhoef studeerde beleid en management gezondheidszorg aan de Erasmus Universiteit Rotterdam en promoveerde aan de Universiteit Maastricht op 'Effect evaluation of substituting physicians for nurses in the care for chronically ill'. Hij was daar postdoc onderzoeker, universitair docent, universitair hoofddocent en senior research fellow bij de afdeling Transmurale Zorg en later hoofd onderzoek. Sinds eind 2009 is hij bijzonder hoogleraar chronische zorg aan de Universiteit van Tilburg (Tranzo).

Martine Wolfaert is verpleegkundige en werkt sinds 1997 bij Coda, een hospice voor palliatieve zorgen, dat in het bosrijke Wuustwezel van de Belgische Noorderkempen ligt. 


\section{Register}

aanbod palliatieve zorg 11 aanpassingsstoornis 121 aanvaarden sterven $7 \circ$

ACT (Association for Children with Life-

threatening or Terminal Conditions and

Their Families) 162

actoren palliatieve zorg 11

ademhaling, reutelende 138

ademhalingsdepressie 112

adjuvante medicatie 113

advance care planning 16,55

afscheid 95

afscheidsritueel 94

afzien van behandeling 31

Agora 22, 53

allochtone patiënten 172

andere ziektebeelden 21

angst 118

angststoornis 118

anorexie-cachexie 113

anorexie-cachexiesyndroom, primair 114

Association for Children with Life-threatening

or Terminal Conditions and Their Families

(ACT) 162

belevingsperspectief patiënt 117

beroepsprofielen 76

beslissingen rondom levenseinde $7,31,35,87$

betrokkenheid 72

bijna-thuis-huizen 17

braken 138

communicatie 125

met kinderen 169

tussen zorgverleners 170

competenties 76

specifieke 77 complementaire zorg 109, 144

gebruik 144

omschrijving 144

opleiding 147

richtlijnen 147

verplegingverzorging 145

Consultatie Nederland ${ }_{56}$

consultatieteams 20

controle, verhogen 126

coördinatie zorg thuis 58

copingreacties 122

dagbehandeling $\sigma_{1}$

dagcentra 61

dagopvang $6_{3}$

deelname in beslissingen 126

definitie palliatieve zorg 14

kinderen 162

Demeester, Wivina 25

dementie 156

anticiperend beleid 157

familie 158

pijn 159

pneumonie 160

prognose 157

vocht- en voedinginname 159

wilsonbekwaamheid 157

depressie 120,121

Diagnostic and Statistical Manual of Mental

Disorders (DSM-IV) 121

DNR-codes 32

doorbraakmedicatie 136

dosering pijnmedicatie 111

DSM-IV 121

emotionele steun 103

empathie 125 
ervaringsleren 39

euthanasie 19, 33

euthanasiewet 33

familie 5,67

familiezorgers 103

fatalisme 123

Federale Evaluatiecel Palliatieve Zorg 26

Federatie Palliatieve Zorg Vlaanderen

(FPZV) 27

fighting spirit 123

financiering 21,44

FPZV (Federatie Palliatieve Zorg

Vlaanderen), 27

geschiedenis palliatieve zorg Nederland 17

euthanasie 19

hospicebeweging 17

overheidsbeleid 20

geschiedenis palliatieve zorg Vlaanderen 24

overheidsbeleid 26

pioniersjaren 24

professionalisering 25

regelgeving 27

gespecialiseerd personeel $6_{3}$

gezinsleden, rol 166

hopeloosheid 123

hospice $17,18,65$

high-care $6_{5}$

low-care 65

hospicebeweging 17

hulp bij zelfdoding 34

IASP (International Association for the Study of Pain) 110

IKMN (Integraal Kankercentrum

Midden-Nederland) 150

IKNL (Integrale Kankercentra Nederland) 150 informatieverstrekking 125

instrumentele steun 104

Integraal Kankercentrum Midden-Nederland

(IKMN) $15^{\circ}$

Integrale Kankercentra Nederland (IKNL) 150

integrale zorg 80

intensieve pijnbestrijding 32

interactief leren $\mathbf{4 1}$

International Association for the Study of Pain (IASP) 110

intramurale palliatieve zorg Nederland 52 intramurale palliatieve zorg Vlaanderen 50 jonge kinderen 93

kanker 21

kinderen 162

benauwdheid 168

comfortinterventies 169

in de palliatieve zorg, aantallen $16_{3}$

ondersteunende medicatie 168

pijn 166

plaats van de zorg 164

specifieke kenmerken zorg 165

thuis sterven $16_{4}$

kinderenpatiëntengroepen 163

koepelorganisaties 22

kortademigheid 138

Kübler-Ross, Elisabeth 40

kunstmatige vochttoediening 139

kwaliteit van leven 82,126

landelijke richtlijn palliatieve sedatie 33

Leontine, zuster 25

leren van anderen 39

levensbeëindigende middelen 33

levensbeëindiging 34

levensbeëindiging uit medelijden 34

Liverpool Care Pathway 46

locatie van zorg 88

medicalisering 6

mensen met verstandelijke beperking 178

praten 179

problemen 178

rol zorgverleners 181

model-leren 40

morele houding zorgverleners 71

morfine 112

tolerantie 112

morfinefobie 32

multidisciplinaire begeleidingsequipe 48

multidisciplinaire palliatieve

thuiszorgequipe 26,57

multidisciplinaire zorg 5

multidisciplinair team 100

multidisciplinair werken 81

naasten $29,81,132$

nausea 138

Nederlands Tijdschrift voor de Palliatieve

Zorg 153

Netwerk Palliatieve Zorg voor Terminale Patiënten Nederland (NPTN) 22 
netwerken palliatieve zorg 20 netwerken palliatieve zorg Nederland 44 netwerken palliatieve zorg Vlaanderen 47 niet-behandelbeslissingen 31

niet-westerse patiënten 172 communicatie 172

lichamelijke verzorging 174

medicatie 175

omgaan met ziekte 176

overlijden 176

pijn 174

religie 176

vasten 175

voeding 175

NPTN (Netwerk Palliatieve Zorg voor

Terminale PatiÎnten Nederland) 22

NSAID's 167

ondersteuningsmogelijkheden

Nederland 56

onderwijs 83

onthouding vocht en voeding 33

onwillekeurige bewegingen 139

opleiding 38

opleidingsdocumenten 76

organisatie palliatieve zorg Vlaanderen 28

organisch geinduceerde angst 119

ouders, rol 166

Oxford Textbook of Palliative Care for

Children 167

palliatief statuut 29

palliatief supportteam 26,51

palliatief zorgcontinuüm 15

palliatief zorgforfait 29

palliatieve sedatie 32,139

palliatieve zorgcultuur 47

palliatieve zorgeenheid 50

palliatieve zorg thuis 54

Palliative Performance Scale 135

Pallium 153

pastores 92

pathologische angst 119

pijn 138,110

pijnbeoordelingsinstrumenten 180

pijnbestrijding 32

pijnladder 111

pijnmedicatie 167

psychiatrische patiënten 185

familie 188

ondersteuning 187 pijncontrole 187

spirituele ondersteuning 188

zorgcontext 186

psychosociale hulpverleners 97

psychosociale zorg 100, 117, 124, 140

reactieve angst 118

reflexief leren 38

refractaire symptomen 32

residentiële Vlaamse ouderenzorg 51

richtlijnen 150

format 153

geschiedenis 150

overzicht 153

richtlijnontwikkeling 152

rusteloosheid 139

samenwerking kennis 86

tijd 86

vaardigheden 86

verpleegkundigen-artsen 85

verwachtingen patiënten 89

Saunders, Cicely 17, 110

sfeer 66

sociale steun 125

speciale patiëntengroepen 21

specifieke zorg, dementie 156

spirituele omgeving 133

spirituele zorg 129

spirituele zorg, patiënt 130

St. Christopher's Hospice 17

sterven $\mathbf{1 3 5}$

stervensfase 140

Stichting dr. Elisabeth Kübler-Ross 17

supportieve dagcentra $6_{3}$

symptoombeleid 137

symptoombestrijding 82

symptoomcontrole 15

team, lerend 101

teamverband 88

terminale fase 136

terminale zorg $6_{2}$

therapeutische hardnekkigheid 31

thuiszorg 28

thuiszorgorganisaties 20

transdisciplinair 100

transities 98

urine-incontinentie 138 
verbaal beschrijvende schaal (VBS) 167 verdriet 120

Vereniging van Integrale Kankercentra

(VIKC) 150

vermoeidheid 110

verpleeg- en verzorgingshuizen 20

verpleeghuizen 52

verpleegkundigen in palliatieve zorg 70

verschillen Nederland-Vlaanderen 6

verstandelijke beperking 178,180

vertrouwen 73

verwardheid 139

verwerking 122

verwijzing naar vrijwilligers 107

VHN (Vereniging Vrijwilligers Hospicezorg Nederland) 22

VIKC (Vereniging van Integrale

Kankercentra) 150

visueel analoge schaal (VAS) 167

voedingsstatus 115

VPTZ (Vrijwilligers Palliatieve Terminale

Zorg) 2.2 vrijwilligers $48,103,105$

Vrijwilligers Palliatieve Terminale Zorg

(VPTZ) 22

vrijwilligers thuis 105

vrijwilligerswerk 19,25

waken 94

websites palliatieve zorg

internationaal 194

websites palliatieve zorg Nederland 191

websites palliatieve zorg Vlaanderen 193

wederkerige relatie 74

WHO, definitie 14

wilsonbekwaamheid 157

Wilsverklaring 27

zingeving 127

Zorgpad Stervensfase 142

zorgverlener 132

zweten 139 
Verpleegkundigen lopen voorop in expliciete aandacht voor de zorg tijdens de laatste levensfase van hun patiënten. Mede door hun inzet $\mathrm{kwam}$ in de laatste decennia van de vorige eeuw een professionele en wetenschappelijke benadering van de palliatieve zorg voort.

In Palliatieve zorg door verpleegkundigen wordt een overzicht gepresenteerd van deze zorg in Nederland en Vlaanderen. Een keur van deskundigen staat op heldere wijze stil bij wat palliatieve zorg is, de geschiedenis, de huidige organisatie, de inhoud ervan, en bij de verschillende moeilijke beslissingen aan het levenseinde.

Zij belichten uitgebreid de inhoud van de zorg en de samenwerking met andere professionals, zoals artsen, geestelijk verzorgers, psychiaters en psychologen. In een apart hoofdstuk wordt ingegaan op de palliatieve zorg voor specifieke groepen, zoals kinderen, mensen met dementie, psychiatrische patienten en mensen uit andere culturen.

Dr. Adriaan Visser is psycholoog, onderzoeker in de psycho-sociale oncologie: assistant lector transities in zorg, Hogeschool Rotterdam.

Prof dr. Johan Bilsen is diensthoofd van de vakgroep Maatschappelijke gezondheidszorg. Vrije Universiteit in Brussel; senior onderzoeker bij de VUB-UGent-onderzoeksgroep Zorg rond het Levenseinde en verpleegkundige. Prof.dr. Anneke Francke is bijzonder hoogleraar Verpleging en verzorging in de laatste levensfase, Vrije Universiteit in Amsterdam; coördinator bij het NIVEL van het onderzoeksprogramma Verpleging en Verzorging.

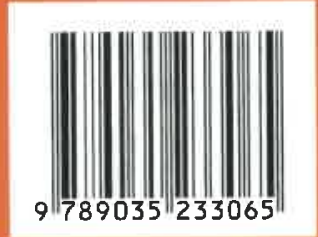

